2at 


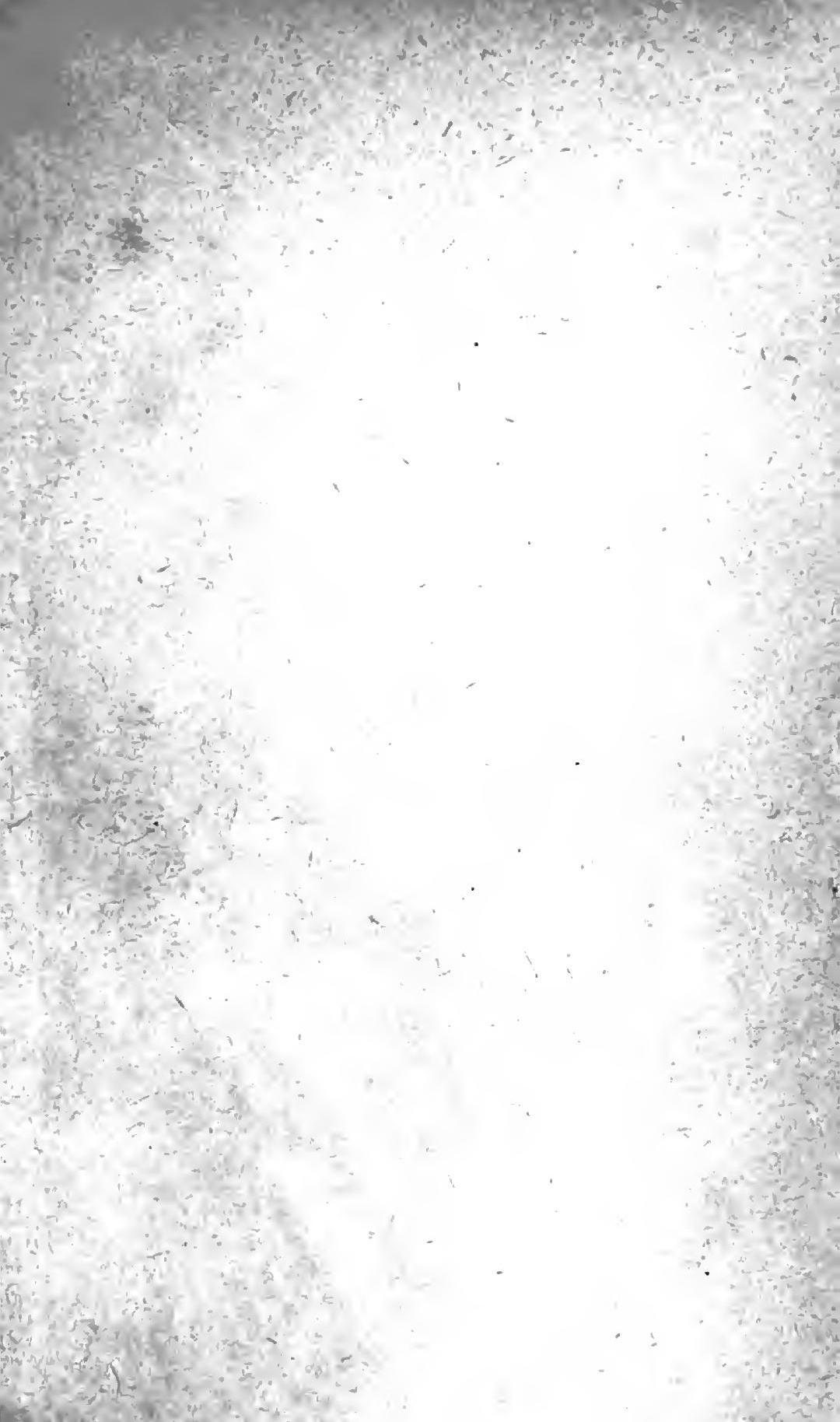




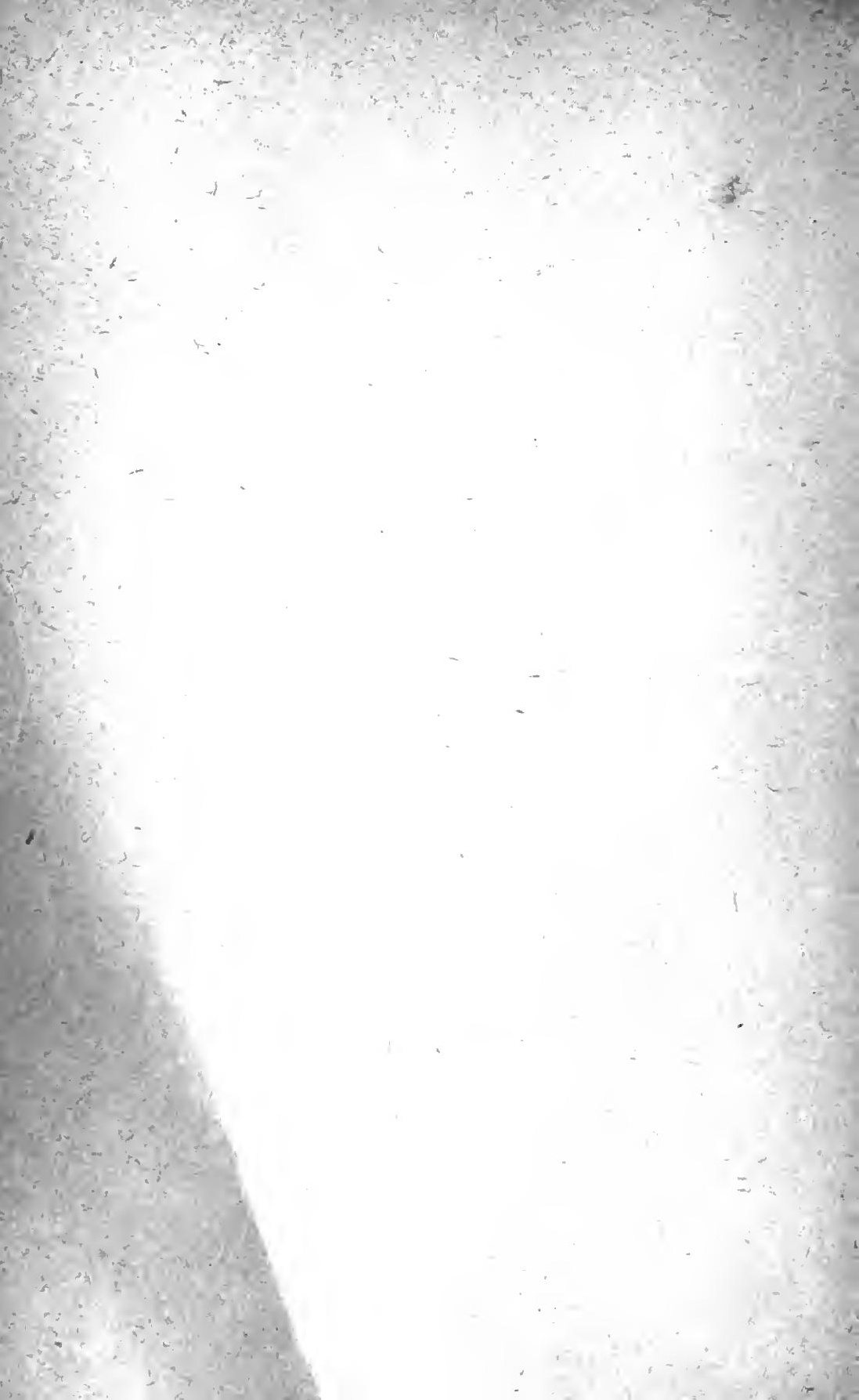


Digitized by the Internet Archive in 2007 with funding from Microsoft Corporation 


\section{A DICTIONARY \\ $\mathrm{OF}$ \\ ORIENTAL QUOTATIONS}




\section{SONNENSCHEIN'S REFERENCE SERIES}

I. English Quotations (4th Edition),

P. H. Dalbiac.

2. Classical Quotations (3rd Edition),

T. B. Harbottle.

3. French and Italian Quotations (2nd Edition),

T. B. HaRbottLe.

P. H. Dalbiac.

4. German Quotations, - Lilian Dalbiac.

5. Contemporary (English) Quotations,

H. Swan.

6. Famous Sayings and their Authors,

E. LATHAM.

7. Dictionary of Historical Allusions, (2nd Edition), . . T. B. Harbottle.

8. Dictionary of Battles, . T. B. Harbottle.

9. Dictionary of Indian Biography,

C. E. Bucki.AND, C.I.E.

Io. Dictionary of Political Phrases and Allusions, Hugh MONTgomery. P. G. Cambray.

II. Spanish Quotations, . T. B. Harbottle. Major Martin Hume.

12. Oriental Quotations, . . Claud Field.

I3. Dictionary of Abbreviations, W. T. Rogers. [In prep. 
A DICTIONARY OF ORIENTAL QUOTATIONS

(Qxrabic and (Persian)
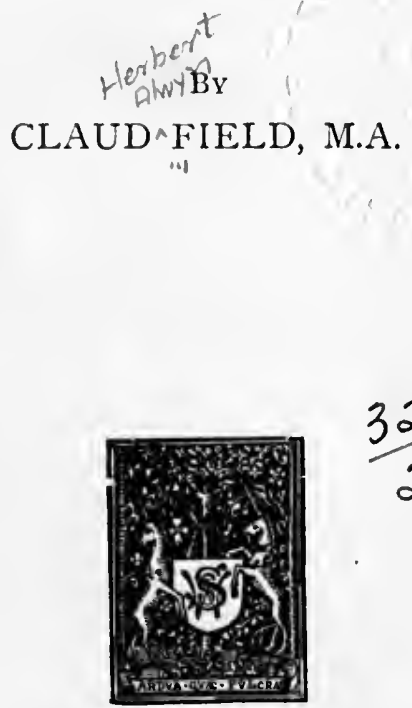

$\frac{3213.97}{21.11 .35}$

LONDON

SWAN SONNENSCHEIN \& CO., LIM.

NEW YORK: THE MACMILLAN CO.

I9I I 
PN

6095

$07 F 6$ 


\section{PREFACE.}

In presenting these specimens from the still hitherto largely unworked mines of the Orient, the compiler desires to thank warmly the following Oriental scholars who have allowed him to make use of their translations : Sir C. J. Lyall, K.C.S.I., Professor Margoliouth of Oxford, Professors Browne and Nicholson of Cambridge, Mr. Whinfield, and the owners of the copyright of the late Col. Wilberforce Clarke's works. He also wishes to thank Messrs. Kegan, Paul, Trench \& Co. for allowing him to quote from Redhouse's translation of the Masnavi and Bicknell's translation of Hafiz, and Mr. T. Fisher Unwin for permitting quotations to be made from Professor Browne's Literary History of Persia. In transliterating Arabic the compiler has adopted the system of Professor Palmer in his Arabic Manual. In transliterating Persian he has for the most part adopted that of Mr. Tolbort in the Persian translation of "Robinson Crusoe."

No better motto for the student of Oriental verse, whether in the original or in a translation, can be found than the words of Goethe in the "West-oestlicher Diwan :"

Herrlich ist der Orient

Ubers Mittelmeer gedrungen ;

Nur wer Hafiz liebt und kennt

Weiss was Calderon gesungen.

C. F. 



\section{Arabic and Persian Sayings}

"Ab-i-hayat ast'ishq, dar dil wa janash pazir."

Diwan-i-Shams-i-Tabriz.

"Love is the water of life ; receive it in thy heart and soul."

Nicholson.

"Ab-i-hayat tira-gun shud, Khizr farrukh pai kujast?

Khun chakid az shakh-i-gul; bad-i-baharanra che shud?"

ANWAR-I-SUHEILI.

"Dark have grown life's fairy waters; where is holy Khizr say?

From the ruse-bough blood is dropping; where do spring's soft breezes stray?"

(EASTWICK).

"A bar amad wa baz bar sar-i-sabza girist

Be bada arghawan na mi bayad zist,

In sabza ki imroz tamashagah' $\Theta$ mast

Ta sabza'e khak-i-ma tamashagah'e kist."

Omar Khamam.

"Down rain the tears from skies enwrapt in gloom Without this wine the tulips could not bloom.

As now these flowerets yiell delight to me

So shall iny dust yield flowers, God knows for whom."

WHINFIEßD.

“Abar gar ab-i-zindagi barad

Hargiz az shakh-i-bed bar na khori

Bar faromaya rozgar mabar

Kaz nai boriya shakar nakhori."

GuListas, chap. I.

"What though life's water from the clouds descend

Thou'llt ne'er pluck fruit from off the willow-bough ;

Not on the base thy precious moments spend

Thou'llt ne'er taste sugar from the recd I trow."

(EAstwick). 
Abasa wa tawalla 'an ja'ahu 'l'ama, wa ma yudrika la'allahu yazzakka au yadhahakkaru fatanfa'hu' Idhdhikra, 'amma mani 'staghna fa'anta lahu tasadda wa ma 'alaika 'alla yazzakka wa amma man jaaka yas'a wa huwa yakhsha fa'anta 'anhu talaha kalla innaha tadhkiratun."

KORAN, chap. 8O.V.I

"He (Muhammad) frowned and he turned his back because the blind man came to him, but what made thee know whether he would not aim at holiness, or be warned and the warning profit him.) But as to him who has become wealthy, him thou didst receive with honour, yet it is not thy concern that he endeavours not to be pure, but as to him who cometh to thee earnest and full of fears him dost thou neglect. Do not so ; verily it is a warning."

RODWELL.

“Ablahe k'u roz-i-roshan sham'a-i-kafuri nihad

Zud bashad k'ash bashab raugan na bashad dar chiragh."

Gulistan, chap. $\mathrm{x}$.

"The dolt who in bright day sets up a camphor light

Soon thou wilt see his lamp devoid of oil at night."

(EASTWICK).

"Adam che serahe buad wa ruh chu mai

Qalib chu nai buad sada'e dar wai

Dani che buad adam-i-khaki Khayyam

Fanus-i-khiyali wa chiraghe dar wai."

Omar Khayyam.

"Man is a cup, his soul the wine therein,

Flesh is a pipe, spirit the voice therein,

O Khayyam have you fathomed what nıan is?

A magic lantern with a light therein."

(WhINFIELD).

" 'A'da 'aduwwika nafsuka 'llati baina jambaika."

Gulistan, chap. 7.

"The most malignant of thine enemies is the lust which abides within thee."

(EASTIVICK).

"Addaulat rihun qullabun w'alqudrata barqun khullabun."

Maqamat of Hariri, chap. 2x.

"Dominion is a breeze that changes, and power is a lightning that deceives."

(CHENERY).

"Adl wa insaf dan na kufr wa na din

Anche dar hifz-i-mulk dar kar ast

Adl be din nizam 'alam ra

Bihtar az zulm-i-Shah dindar ast."

Jam. Blharistan.

"Be aware that justice and equity not unbelief nor religion

Are needed for the maintenance of the kingdom.

Justice without religion is for the next world

Better than the tyranny of a religious Shah."

(REHATSEK). 
"'Afala yatadabbaruna 'Iqurana, am 'ala qulubin aqfaluha."

КокАN, chap. 47.

"Will they not then meditate on the Koran? Are locks upon their hearts?"

Roswet.l.

"'Afalam yasiru fll'ardhi fatakuna lahum quiubun ya'qiluna biha, au adhanun yasma'una blha, fa'innaha la ta'ma'l'absaru walakin ta'ma 'lqulubu 'llati fl'ssuduri."

KокAN, chap. 22.

"Have they not then journeyed through the land? Have they not hearts to understand with, or ears to hear with? But it is not verily that their eyes are blind, but the hearts that are in their breasts are blind."

RONWEL.L.

“'Afaman 'assasa bunyanahu ala taqwa mina 'llahi waridhwanin khairun 'am man 'assasa bunyanahu ala shafa jurufin harin fa'nhara bihi fl nari jahannama?"

Kokax, chap. 9.

"Which of these two is best? He who hath founded his building on the fear of God and the desire to please Him, or he who hath founded his building on the brink of a tottering water-worn bank so that it falleth in ruin with him into the fire of hell?"

(RONWELL).

"Afaman wa'adnahu wa'dan hasanan fahuwa laqihi kaman matt a'nahu mata'a 'lhayati 'ddunya thumma huwa yauma 'lqiyamati mina 'lmuhdharin."

KoRAN, chap. 28.

"Shall he then to whom we have promised a goodly promise which he shall meet with, be as he on whom we have bestowed the conveniences of this life present, and who on the day of resurrection shall be brought forward for punishmen ?"

(RODIVELL).

"Afani 'llahu wa shukran lahu min illatin kadat tu "affini. wa manna bi'lburan 'ala 'innahu la budda min hatfin sayabrini ma yatanasani wa lakinnahu ila taqadhdhi l'ukli yunsini,

in humma, lam yugni hamimum wa la hima Kulaybin minahu yahjini."

"God has saved me, thanks be to Hin from a sickness that went near to blot me out

And has granted me recovery; though it must needs be that death will one day waste me.

Death forgets me not yet He gives me a delay before the end of my feeding ;

If it be decreed, then will no friend avail, nay not even the guarded domain of Kolayb to guard me from Him."

Hakiri Maqumat. ig.

"Afa'anta tukrihu 'nnasa hatta yakunu muminin?"

КокAN, chap.

"Wilt thou then compel men to becume believers?" (KODWELL). 
“'Afa'anta tusmi'u 'ssumma au tahdi 'l'uma wa man kana fl dhalalin mubin."

Koran, chap. 43 .

"Canst thou make the deaf to hear, or canst thou direct the blind and him who is in a manifest error?"

(SALE).

\section{“" 'Afati 'lddiyaru mahalluha famuqamuha \\ Biminan ta'abbada ghauluha farijamuha \\ Famadaafl'u 'rraiyyani 'urriya rasmuha \\ Khalaqan kama dhamina 'lwuhiyya silamuha \\ Dimanun tajarrama ba'da 'ahdi anisiha \\ Hijajjun khalauna halaluha waharamuha." MU'AlL +QAн OF LEBID.}

"Desolate are the mansions of the fair, the stations in Mina where they rested and those where they fixed their abodes. Bare are the hil's of Ghaul and deserted is the summit of Rijam.

"The canals of Raiyyan are destroyed : the remains of them are laid bare and smonth by the floods, like characters engraven on the solid rocks.

"Dear ruins! many a year has been closed, many a month holy and unhallowed has elapsed since I exchanged tender vows with their fair inhabitants." SIR IV. JoNes.

"Aftab amad dallt-i-aftab."

Jalalludin Rumi.

"None but the sun can display the sun."

IVHINFIELD.

" Agarat murad.bashad ki namiri wa bimani

Birihan bi jihad khudra za jahan dun fani

Za tan wa za jan wa az dil bugzar, masaz manzil

Ki shawad sifat hasil bimurad wa kamrani."

Diwan-I-Shams-1.Tabriz.

"Pants thy spirit to be gifted

With a deathless life,

Let it seek to be uplifted

O'er earth's storm and strife.

Spurn its joys,-its ties dissever,

Hopes and fears divest ;

Thus, aspire to live for ever,

Be for ever blest.

(FALCONER).

"Agar baran bakohistan nabarad

Basali Dijla gardad khushk rude."

Gelistan, chap. 7 .

"If on the mountain summits fell no rain, One year would make the Tigris channel dry." (EASTIICK).

"Agar biryan kunad Bahram ghori

Na chun pae malakh bashad za mori."

Gulistan, chap. 2.

" A locust's leg, the poor ant's gift is more

Than the wild ass, dressed whole, from Bahram's store."

(EAsTwiCk). 
" Agar dana'e hila pashad kase

Ba dam awarad murgh-i-zirak base."

ANWAR-1-SuHeill.

"If one the grains of craft around him fling

Sly birds enow he'll to his snare soon bring."

Eastwick.

"Agar dunya na bashad, dardmandem

Wa agar bashad, ba mihrash pae bandem

Bala'e z'in jahan ashubtar nest

Ki ranj-i-khatirast ar hast wa nest.

Gulistan, chap. 2.

" Have we no worldly gear,-'tis grief and pain,

llave we it, then its charms our feet enchain.

Can we than this a plague more troublous find

Which absent, present, still afflicts the mind."

(EASTwick).

" Agar sad sal gabar atish farozad

Wa gar ek dam daru uftad basozad."

Gulistan, chap. 1 .

"Though for a hundred years the Guebre feeds his flame

Did he once fall therein 'twould feed on him the same."

(EASTIVICK).

“ Agar za bagh-i-r'ayyat malak khurad sebi

Bar aurand ghulaman-i-u darakht az bekh

Ba nim baiza ki sultan sitam rawa darad

Zanand laskarianash hazar murgh ba sekh."

"If but one apple from the peasant's field

The king should eat, his men uproot the tree;

And does the Sultan but his sanction yield

To extort five eggs-his followers will see

Cause with a thousand pullets to make free."

(EASTWICK).

'Ahanera ki morchana bikhurad

Natawan burd azū basaiqal zang ;

Ba siyah dil che sud guftan w'az?

Narawad mekh-i-ahanin dar sang."

Gulistan, chap. 2.

"When rust deep-seated has consumed the steel

Its stain will never a new polish own.

Advice effects not those who cannot feel

A nail of iron cannot pierce a stone." Eastwick.

Ahl-i-zamana ki wafa nest yar eshan

Matalab wafa ki ghair jafa nest kar eshan." ANwsk-1-StheIL.,

"Faith does not company with worldly men.

From those habit is injustice, then

Expect not truth."

Eastwick. 
"Aibist azim barkashidan khudra, W'az jumla'e khalq barguzidan khudra, Az mardumak-i-dida bibayad amokht Didan hama kasra wa na didan khudra."

HAFIZ.

" It is a crime to seek to raise but self, Before all other men to praise but self, The pupil of the eye a lesson gives, Be all sulomitted to thy gaze but self."

(Bickneit.).

" 'Ajab, 'ajab, bakudamin rah az jahan rafti, Base zadi par wa bal wa qafs dar ishkasti, Hawa girifti wa sue jahan-i-jan rafti Tu baz-i-khass budi dar wisaq-i-pir zani, Chu tabl-i-baz shunidi, balamakan rafti."

Diwan-I-Shams-I-Tabriz.

"Tis marvellous by what way thou wentest from the world

Thou didst strongly shake thy wings and feathers and having broken thy cage

Didst take to the air and journey towards the world of soul.

Thou wert a farourite falcon kept in captivity by an old woman

When thou heard'st the falcon-drum, thou didst fly away into the void."

“Ajaban lirajin an yanala wilayatan

(NICHOLSON).

Hatta idhama nala bighayatihi bagha." MaQquat of Hariri (2r).

"Wonderful! a man hoping to attain to rule, and then when he attains to his desire, he wrongs.

Chenery.

“Aj'ali lmauta nasba 'ainik wa haza flraqu baini wa bainik."

Maqamat of Hariki, chap. 50. me."

"Keep death before thine eye and this is the parting between lhee and

" Akhir in jan ba badan paiwasta ast

Hech in jan ba badan manasta ast

Tab nur-i-chashm ba pih ast juft

Nur-i-dil dar qatra'e khuni nihuft

Shadi andar gurda wa gham dar jigar

Aql chun shama' darun maghaztar

In taalquha na be kaifast wa chun

Aqlaha dar danish chuni zabun."

JALALUDdin RUMi.

"After all soul is linked to body

Though it in nowise resembles the body

The power of the light of the eye is mated with fat

The light of the heart is hidden in a drop of blood

Joy harbours in the kidneys and pain in the liver

The lamp of reason in the hrains of the head.

These connections are not without a why and how

But reason is at a loss to understand the how." (Whinfield). 
Aklbat gurg-zade gurg shavad

Garche ba adami buzurg shavad."

Gulistan, chap. x.

"At length the wolf-cub will become a wolf

Even though it grow up amongst men."

(E. G. IBROWNE).

"Akhmid bihilmik ma yudhkihi dhu safa'in

Min narl ghaidhik w'asfah in jana jani."

Magqamat of Hariri, chap. 47.

"Quench by thy inercy the fire of anger that a churl has recklessly kindled in thee, and pardon his trespass."

STEINGass.

"Aknun ki dam za umr mahrum nashud, Kam bud az asrar ki mafhum nashud, Chun nek hame bingiram az rue khird Umaram biguzasht wa hech m'alum na shud."

Omar Khayyam.

"Whilom, ere youth's conceit had waned, me thought Answers to all life's problems I had wrought; But now, grown old and wise, too late I see My life is spent, and all my lore is nought."

(WHINFIELD).

"Aknun ki za khushdili bajuz nam namand,

Ek hamdam-i-pukhta juz mai-i-kham namand, Dast-i-tarab az saghir-i-mai baz magir Imroz ki dar dast bajuz jam namand."

Omar Khayyam.

". Now of old joys nought but the name is left

Of all old friends but wine we are bereft

And that wine new ; but still cleave to the cup

For save the cup what solace is there left.

(WhiNFIEI.D).

Akrim ud dhaifar wa lau kana kafira."

Saying of Muhamado.

"Honour the guest though he be an infidel."

"Aksar ahl al jannat ablah, ai pisar,

Bahr in guft sultan ul bashar

Ziraki chun bad kibr-angez t'ust

Ablahe shu ta bamanad din durust."

Jal.Al.undi: Rum.

"For this cause, $\mathrm{O}$ son, the Prince of men declared

'The majority of those in Paradise are the foolish'.

Cleverness is as a wind raising storms of pride

Be foolish, so that your heart may he at peace."

WHIXYFIEI.D. 


\section{"Akullu 'amran tahsabina umran, wa' nara taharriqa bi'laili naran?" \\ ABU DU'AD.}

"Thinkest thou every man, a man; every fire that burns at night a fire?"

D. S. Margoliouth.

"Ala la tahzannana akha' lbaliyyat

Falirrahmani 'Itafun khaflyyat."

Gulistan, chap. 1 .

"Oh, ye brothers of misfortune! he not ye with grief oppressed

Many are the secret mercies which with the All-bounteous rest."

(EASTWICK).

“'Alaika bi’ssidq1 wa lau annahu 'ahraqaka 'ssidqu binari 'lwa'id wa'bghi ridha 'llahi fa'aghba 'lwara man 'askhata 'Imaula wa'ardha 'l'abid."

Hariri MaqaMAT 2 r.

"Keep to truth though it scorch thee with the fire of threatening, and seek to please God; for the most foolish of mankind is be who angers the master and pleases the slave."

(Chenery).

“'Al'alimu arafa 'Ijahila l'a'innahu kana jahilan, wa'ljahilu la yarifu 'lalima l'ainnahu ma kana 'aliman."

"The wise man understands the fool for he was once a fool hinself, but the fool does not understand the wise man because he was never wise."

Prov.

"'Alam nashrah laka sadraka wa wadha'naa 'anka wizraka 'ladhi anqadha dharaka waraf'naa zikraka, fainna ma'a 'lusri yusra, inna ma'a l'usri yusra, faldha faraghta fa'nsab wa'ila rabbika fa'rghab."

KORAN, chap. 94.

" Have we not opened thy breast for thee? and taken off from thee thy burden, which galled thy back? and have we not upraised thy name for thee? Then verily along with the difficulty cometh ease, verily along with the difficulty cometh ease. But when thou art set at liberty, be instant in prayer, and seek thy Lord with fervour."

“'Alam naj'ali 'lardha kifatan 'ahaiyan wa'amwatan wa ja'alna tha rawasya shamikhatin w'asqainahum ma'an furatan. Wailun yaumaidhin lilmukadhdhibin "intaliqu ila ma kuntum bihi tukadhdhibun intaliqu ila dhillin dhi thalathi shu'abin." KORAN, chap. 77.

"Have we not made the earth a receptacle for the living and the dead, and placed on it the tall firm mountains and given you sweet water to drink? Woe on that day to those who charged with imposture! 'Begone to that hell which ye called a lie : begone to the shadows that lie in triple masses." "

RODWEL.L. 
"'Alam tara 'anna 'llaha yusabbihu lahu man fl'ssamawati wa' lardhi wa'ttairu saffatin kullun qad 'alima salatahu watasbiyahu wa'llahu 'alimun bima yafalun."

KоклN, chap. 24.

"Hast thou not seen how all in the heavens and in the earth uttered the praise of God? and the very hirds as they spread their wings? Every creature knoweth its prayer and its praise, and God knoweth what they do."

ROINWELL.

“'Alam tara anna 'llaha 'anzala mina 'ssamaai maan fakhrajna bihi thamaratin mukhtalifun alwanuha wa mina '1jibali judadun biyadhun wa humrun mukhtalifun 'alwanuha wa gharaabibu sudun wa mina 'Inasi a' ddawatti w'lan'ami mukhtalifun alwanuhu."

KORAN, chap. 35 .

"Dost thou not see that God sendeth down the rain from heaven and we bring by it the upgrowth of fruits of various hues and that on the mountains are tracts of varied hues white and red and others are of a raven black? And of men and reptiles and animals various likewise are the hues."

RODWELL.

"Alam tara anna 'Ifulka tajri fl'lbahri bin'imati 'llahi 'liyuriyakum min ayatihi inna fl dhalika layatin likulli sabbarin shakur."

KORAN, chap. 3I.

"Seest thou not how the ships speed on in the sea through th.e favour of God that He may show you of His signs? Lo, herein are signs to every patient grateful person."

RODWELL.

"Alam tara lla rabbika kaifa madda 'dhilla wa lau sha'a laja'alahu sakinan, thumma ja 'alna 'shshamsa alaihi dalila."

KORAN, chap. 25.

"Seest thou not how thy Lord stretcheih forth the shadow? if He so pleased, he had made it stationary; but we bring the sun upon it thus guiding its direction."

(MUIR).

“Alam tara kaifa fa'ala rabbuka bi'ashabi 'lfl, alam yahj'al kaidahum fil tadhlil, wa'arsala alaihim tairan 'ababil, tarmiyihim bihajaratin min sijill, faja'alahum ka'asfln ma'kul." KокA^, chap. ıо5.

" Hast thou not seen how thy Lord dealt with the army of the elephant? Did He not cause their stratagem to miscarry? and He sent against then birds in flocks, claystones did they hurl down upon them, and he made them like stubble eaten down."

(RONWELL).

\section{"'Alam ya'ni lilladhina amanu 'an takhish'a qulubuhum lidhikri 'llahi." \\ KORAN, chap. 57 .}

"Hath not the time come for those who have believed to humble their hearts at the warning of God:"

(RODWELI.). 
"Alam yarau 'anna ja'alna 'llaila liyaskunu fihi wa'nnahara mubsiran "inna fi dhalika laayatin liqaumin yuminun."

Korax, chap. 27.

"See they not that we have ordained the night that they may rest in it, and the day with its gift of light? Of a truth herein are signs to people who believe."

(RODWELI.).

" 'Alam wahm wa khiyal wa tab'a wa bim

Hast rahrau-ra eke sadd azim ;

Naqshae in khiyal naqsh band

Chun Khalili ra ki koh bud, shud gazand

Guft 'Hadha Rabbi' Ibrahim rad.

Chunki andar 'alam wahm uftad

Alam wahm wa khiyal wa chashm band

Anchunan koh-ra za jae khwesh kand ;

Taki 'Hadha Rabbi' amad qal-i-u

Kharbat wa khar-ra che bashad hal-i-u?"

Jalaluddix Rum.

" This world of illusions, fancies, desires and fears

Is a mighty obstacle in the traveller's path.

Thus when these forms of delusive imaginations

Misled Abrahan, who was a very mountain of wisdom.

He said of the star 'This is my Lord'.

Having fallen into the midst of the world of illusion

Seeing then that this world of eye-fascinatiug illusion

Seduced from the right path such a mountain as Abraham.

So that he said of the star 'This is my Lord',

What will not its illusions effect on a stupid ass ?"

WHINFIELD.

"Al' aqilu takfihi 'l'isharatu wa'lghaflu la tanfa"uhu alfu 'ibaratin."

ARabic Protern.

"A hint sufficeth for the wise, but a thousand speeches profit not the heedless."

" Al'ardhu jami 'an qabdhatuhu yauma 'lqiyamati, wa 'ssamawatu matwiyyatun biyaminihi subhanahu wa ta'ala "amma yushrikun."

KonAx, chap. 39.

"On the resurrection day the whole earth shall be but $\mathrm{His}$ handful and in His right hand shall the heaven be folded together. Glory be to Him : and high be He uplifted alove the partners they join with Him."

(RONWLLL).

"Al'arifu hashshun bashshun bassamun wa keyfa la wa huwa farahan bi'lhakki wi bi kulli shey?"

Avicenisa.

"The gnostic is gentle, courteous, smiling; and how should it be otherwise, since he rejoices in God and in all things." (E. G. BRowre). 
"Ala ta na khwahi bala bar hasud

Ki an bakht bargashta khud dar bala ast

Che hajat ki bar wał kunł dushmani

Ki ura chunin dushmani dar qafa ast."

Gichstan, chap. 8.

" Oh on the envious man invoke no curse

For of himself poor wretch, accursed is he ;

On him no hatred can inflict aught worse

Than his self-fed, self-torturing enmity."

(EAST'YICK).

"Ala, ta nashnavi madh-i-sukhan goi,

Ki andak maya'e naf'ai az tu darad;

Agar roze muradash bar niyari,

Do sad chandan "ayubat bar shumarad."

Gulistan, chap. 8.

"Heed not the flatterer's fulsome talk

He from thee hopes some trifle to ohtain;

Thou wilt shouldst thou his wishes baulk

Two hundred times as much of censure gain."

(EASTWICK).

“'Ala ya sakina 'lqasri 'Imualla

Satudfanu 'anqaribin fi'tturabi,

Lahu malakun yunadi kulla yaumin

Ladu lilmauti wa' bnu l'ilkharabi."

Ale al Mtretaza.

"O tenant of the lofty palace

Know that thy grave sluall soon be filled!

It has an angel who cries daily

- J)raw nigh in death, for ruin build." "

(BICkNELL).

"Al faqir la yamlik shaian wa la yumlak." Gulistax, chap. 2.

"The faqir does not possess anything, and is not possessed by anyone."

(EASTWICK).

\section{"Al faqru fakhri."}

SAYTg of MLHaMMM).

"Poverty is my glory."

"Al faqru siwadu 'lwajah fl 'darain." SAvici of M MHamad.

"l'overty blackens the countenance in boll worlds." (EAsTwick).

"Al ghusun idha qawwamtaha, "itadalat, Wa laisa yanfa'uka 'ttaqwimu b'ilkhashbi." Guistan, chap. 7.

"Green branches thou may'st render straight

The attempt to straighten dry wood comes too late."

(EASTWICK). 


\section{"Alhaqqu 'ahaqqu 'an yuttaba'a, w'assidqu haqiqun b'an yusta- m'aa." \\ Maqaitat OF HaRIRI.}

" Right is most worthy to be followed, and truth is most fitting to be listened to."

(CHENERY).

"'Alhakumu 'ttakathuru hatta zurtumu 'lmaqabir, kalla saufa ta'lamun, thumma kalla saufa ta'lamun, kalla lau ta lamuna ilma 'lyaqin lataraunna 'ljahim. thumma lataraunnaha ain 'lyaqin, thumma latus 'alunna yaumaidhin 'ani 'In'ilm." KORAN, chap. 102.

" The desire of increasing riches occupieth you, till ye come to the grave. Nay! but in the end ye shall know. Nay ! once more, in the end ye shall know. Nay : would that ye knew it with knowledge of certainty. Surely ye shall see hell-fire, then shall ye surely see it with the eye of certainty; then shall ye surely on that day be asked concerning the pleasures of this life."

RODWEI.L.

"Al hamdu lillahi rabbi 'I'alamina 'rrahmani 'rrahimi, maliki yaumi 'ddini, iyyaka na'budu wa iyyaka nasta'inu, ihdina 'ssirata 'Imustaqima sirat 'lladhina an'amta 'alaihim ghairi 'Imaghdhubi 'alaihim wa la 'dhdhalin."

KORAN, chap. $x$.

"Praise be to Gorl, Lord of the worlds! The compassionate, the merciful! King on the day of judgment. Thee only do we worship and to Thee do we cry for help. Guide Thou us on the right path, the path of those to whom Thou art gracious, not of those with whom Thou art angered, nor of those who go astray."

RODWFI.

"Al hilmi 'inda 'ljahli li'dhdhillati idh'anu

Wa $f$ 'shsharri najatun hina la yunjika "ihsanu."

ShahL.

"Too kind a man may be with fools

And move them but to flout him more

And inischief of may bring thee pence

When mildness works not folly's cure." C. J. Lyal...

“ Al hilmu 'afdhalu ma' zdana 'labibu bihi

W'al'akhdhu bi'l'afwi 'ahla ma jana jani."

$$
\text { Maqamat of Hariri, (chap. 47.) }
$$

"Mercy is far the best of jewels that grace the wise, and sweetest fruit culled by man is ready forgiveness."

Steinciass.

"Alimera ki guft bashad wa bas

Chun bigoyad na girad andar kas

Alim an kas buwad ki bad nakunad

Na bigoyad ba khalq wa khud bikunad."

Gulistan, chap. 2.

"The sage who does but preach will ne'er

With all his words man's conscience stir

Who does no evil, truly wise is he,

Not one whose acts and docirines disagree." (EAsTwick). 
"Al'izza fl 'nnaqali wa lau 'anna sharafl 'Imawa bulughu munan Lam tabraht 'shshamsu yauman darata 'lhamalt." Aг. Т'снкль.

"If bloated indolence were fame, And poinpous case our noblest aim, The orb that regulates the day

Would ne'er from Aries' mansion stray." J. D. CARLYLE.

"Al ju'u ta'amu 'llahi yuhi bihl 'abaana 'ssaddiqin."

SAYiNG of MUHAMmad.

"Fasting is the food of God whereby Ile revives the bodies of the sincere."

"Al karim Idha wa'ada wafa."

Gluistan, Preface.

"When the generous promise, they perform."

"Alladhina atenahumu 'lkitaba ya'rifunahu kama ya rifuna abnahum wa inna fariqan minhum layaktumuna 'haqqa wahum ya'lamun, alhaqqu min rabbika fala takunanna mina "lmumtarin."

Koras, cliap. 2 .

"They to whom we have given the scriptures know him (Muhaminad) even as they know their own children; but iruly a part of them conceal the truth, though acquainted with it. This truth is from thy Lord; be not then of those who doubt.

RODWELL.

"Allahu la 'llaha llla huwa al haiyyu 'lkaiyyum. La ta'khudhuhu sinatun wa la naum; lahu ma fl essamawati wa ma fl'l ardhi. Man dha 'lladhi yashfa'u indahu illa bi Idhnihi; ya'lamu ma baina aidihim wa ma khalfaham wa la yuhituna bishai'in min 'ilmihi illa blma sha'a. Wasi'a kursiyuhu 'ssamawati wa'l ardha wala ya'uduhu hifchuhuma wahuwa 'l'aliyu 'l'adhim."

KORAx, chap. 2. (The "throne" verse).)

"God! There is no God but He ; the living, the self-subsisting; neither slumber seizeth Him, nor sleep; II is whatsoever is in the heavens and whatsoever is in the earth. Who is he that can intercede with Him except by His permission? He knoweth what is present with His creatures and what is yet to befall them; yet naught of Ilis knuwledge do they comprehend save what He willeth. His throne reacheth over the heavens and the earth and the upholding of both burdeneth Him not : and He is the High, the Great."

RODWELL.

"Allahu 'lladhi rafaa essamawati blgairi 'amadin taraunaha thumma 'stawa 'ala ' 'arshi wasakhkhara 'ashshamsa wa'lqamara kullun yajri la'jalin musamma yudabbari 'la'mr yufassilu 'layati l'aallakum b'llqail rabbikum tuqinun." KOKAN, chap. 13.

"It is God who hath ordered the heavens without pillars which thou canst behold; then seated Ilimself upon His throne and imposed laws on the sun and moon; each travelleth to its appointed goal. He ordereth all things. He maketh His signs clear, if haply ye may believe that ye shall meet your Lord."

RODWEI.L. 
"Allahu latifun bi'abadihi yarzuqu man yashau wa huwa 'lquwiyyu 'l'aziz. Man kana yuridu hartha 'lakhirati nazid lahu fl harthihi wa man kana yuridu hartha 'ddunya nutihi minha wa ma lahu fl 'lakhirati min nasib."

KORAx, chap. 42.

"God is benign towards Ilis servants: for whom He will He doth provi' 'e; and He is the strong, the mighty. Whoso chnoses the tillage of the life to come, to him will we give an ample increase in his tillage; and whoso chooseth the tillage of this life, thereof will we give him; but he shall have no portion in the life to come."

ROIWELI.

"Allahu nuru 'ssamawati wa' lardhi mathalu nurihi kamishkatin flha misbahun almisbahu fi zujajatin ka'annaha kaukabun durriyun yukadu min shajaratin mubarakatin zaitounatin la sharqiyyatin wa la gharbiyyatin yakadu zaituha yudhiyu wa lau lam tamsashu narun, nurun 'ala nurin, yahdi llahu linurihi man yasha'a."

KORAN, chap. 24. $\mathrm{V} \cdot 35$

"God is the light of the heavens and the earth. The similitude of His light is as a niche in which is a lamp-the lamp encased in glass - the glass as it were a glistening star. From a blessed tree is it lighted, the olive neither of the East nor of the West, whose oil would well nigh shine out, even though fire touched it not! It is light upon light! God guideth whom He will to His light."

RolNUEL.L.

"Allahu y'alamu 'anna la nuhlbbukum wa la nalumukum 'ala tuhibbuna

Kullun lahu niyatun fi bughdin sahibihi, bin'imati 'llahi naqlikum wa taqluna."

ABD-UL-MALIK.

"God knows that we, we love you not in sooth, and that we blame you not that ye have no love for us ;

Each of us has his yround for the loathing his fellow moves

A grace it is from the Lord that we hate you, ye us !"

C. J. Lyat.t.

"Almaut khairun li'lfata min 'aishihi 'aisha 'lbahima

Taqtaduhu buratu 'ssaghar ila 'ladhimati w'alhadhima

Wa yara 'ssiba'a tanushuha 'aydi 'dhdhib'ai' Imustadhima."

Maqamat of Hariri, chap. 6 .

" Death is better for a man than to live the life of a beast

When the ring of subjection leads him to mighty trouble and outrage And he sees lions whom the paws of assailing hyaenas seize."

(CHENERY).

"Almuwaddatu muwaddatani, muwaddata wafla wa muwaddata 'afla, fa'lwafla min Allah subhanahu, wa'lafla mina 'shshaitani lanahu 'llaha."

Abu'l.'Ala.

"Love is of two sorts, the sound and the faded. That which is sound is from God Almighty, and that which gets obliterated is from the accursed devil."

D. S. Margoliouth. 
"'Alqari'ah ma' lqariah, wa ma 'adraka ma 'lqariah, yauma yakunu 'nnasu ka'farashi 'Imabthuthi wa takunu 'ljibalu ka'li'hni 'Imanfushi, fa'amma man thaqulat mawazinuhu fahuwa fl aishatin radhiyatin, wa'amma man khaftat mawazinuhu fa ummuhu hawiyatun."

KokAN, chap. zor.

"The Blow! what is the Blow? And what shall teach thee what the Blow is. The day when men shall be like scattered moths, and the mountains shall be like carded dyed wool! Then as to him whose halances are heavy-his shall be a life that shall please him well, and as to him whose balances are light, he shall have hell for his mother."

Rouwell.

"Al qina'atu kanzun la yufna."

Akalic Prov.

"Contentment is a treasure without decay."

"'Alyauma 'akmaitu lakum dinakum wa'atmamtu 'alaikum nl'amati waradhaitu lakumu 'l'islama dinan." KORAN, chap. 5. V.u

"This day have I perfected your religion for you, and liave filled up the measure of my favours towards you, and it is my pleasure that Islam be your religion."

(ROINELL).

“' Ama bana laka 'laibun, ama 'andharaka 'lshaibun wa ma fl nusihi raibun, wa la sam 'uka qad samma, ama nada blka 'lmautu, ama 'asma'aka 'ssautu, ama taksha min 'lfauti, fatahtata wa tahtamma?"

Hakiki Magamat, 2.

"Is not the shame plain to thee? doth not hoariness warn thee? and in its counsel there is no doubtfulness, nor hath thy hearing become deaf. Is not leath calling thee, doth he not make thee hear his vojce? dost thou not fear thy passing away so as to be wary and anxious ?"

Cheners:

"Amada awwal ba qalim jamad

Dar nabati az jamadi uftad;

Salha andar nabati umr kard

W'az jamadi yad na aurad az nabard;

W'az nabati chun ba halwan uftad

Namandash hal nabati hech yad."

JALALCUDIN RuMr.

"First he appeared in the class of inorganic things, Next he passed therefrom into that of plants,

For years he lived as one of the p'ants.

Remembering naught of his inorganic state so different, And when he passed from the vigetive to the animal state He had no remembrance of his state as a plant."

(WHINFIEIJ). 
"Ama' lhimamu mi'aduka, fama i'daduka, wa bi'imashaibi indharuka, fa ma i‘dharuka, wa flllahdi maqiluka, fama qiluka, wa ila 'llaha masiruka, faman nasiruka."

HARIRI MAQAMaT, r.

"Is not death thy doom? what then is thy preparation? Is not grey hair thy warning? what then is thy excuse? And in the grave's niche thy sleeping-place? What dost thou say? and to God thy going, and who shall be thy defender?"

CHENERY.

“'Amal-i-padshahan chun safar-i-daryast sudmand wa khatarnak ya ganj ba giri ya dar talatum-i-amwaj bamiri." Gulistan, chap. I.

"The service of kings is like a sea voyage, at once profitable and fraught with peril : where thou either wilt acquire a treasure or perish amid the billows."

(EASTWICK).

\section{"Ambiyara kar 'uqba ikhtiyar}

Kafiranra kar dunya ikhtiyar ;

Z'anki har murghi basue jins-i-khwesh,

Mirawad u dar pesh jan pesh pesh."

JALALCDDIX RLMI

"The prophets chose the better part, futurity,

The frolish chose the worst, the world's fatuity.

Each bird will flock with birds of its own feather still

The cock well knows his mate and follows where she will."

REDHOUSE.

" 'Amman khalaqa 'ssamawati wa'lardha wa'anzala lakum mina 'ssamai ma'in fa'anbatna bihi hada'aiqa dhata bahjatin, ma kana lakum an tunbitu shajaraha, 'a'ilahun ma'a'ilahi, bal hum qaumun ya'dilun."

KorAx, chap. 27.

"Who hath made the heavens and the earth, and sendeth down the rain to you from heaven, by which we cause luxuriant groves to spring up? Not in your power is it to cause its trees to spring up? What ! A god with God? Yet they are a people who find equals for Him." Ronwell.

“'Am naj'alu 'lladhina amanu wa'amilu 'ssalihati ka'lmufsidina fl'll'ardhi, 'am naj'alu 'lmuttaqina ka'lfujjar." Koras, chap. 37.

"Shall we treat those who leelieve and do the things that are right like those who propagate evil on the earth? Shall we treat the God-fearing like the impious?

(RODWELL).

"Annasu ala dini mulukihim."

Arabic Prov.

"People follow the religion of their kings."

* Andakhta tir ba shast awardan

Bitawan natawan tura ba dast awardan."

ANWAR-I-Suheili,

" Back to thy hand no power can bring

The arrow which has left the string."

EAsTWICK. 
"Anjaza hurun ma wa'ada wa sahha khalun idh ra'ada."

MaQAmat of HaRiRl, chap. 3.

"The honourable man performs what he promises, and the rain-cloud pours if it has thundered."

"An na man basham ki roz-i-jang bini pusht-j-man

An manam k'andar-i-khak wa khun bini sari; Anki jang arad bakhun-i-khwesh bazi mi-kunad Roz-i-maidan, anki bugrezad ba khun-i-lashkari."

GulistaN, chap. I.

"I'm not he that on the battle-day my back will meet thy sight I'm one whose head thou wilt behold 'mid dust and gory figlut He must stake ceaselessly his blood who joins in war's grim strife Who flies in war risks carelessly his fellow soldier's life."

(EASTWICK).

"Anta 'lladhi waladtuka ummuka bakiya Wa' nnasu hauluka yadhahikuna masrura, Fajihad li nafsik 'an takunu idha

Yebku fl yaumi mautuka, dhahika masrura."

"On mother's knees a naked new-born babe

Weeping thou sat'st, while all around thee smiled;

So lite, that sinking to thy life's last sleep

Calm thou may'st smile, while all around thee weep.".

W. JoNES.

"'Anzala mina 'ssamai maan fasalat 'audiyatun biqadariha fa'htamala ssallu zabadan rabian wa mimma yuqiduna alaihi fl'nnari 'btigha hilyatin au matain zabadun mithluhu kadhalika yudhribu 'llahu 'lhaqqa wa'lbatila fa'amma 'zzabadu fayadhhabu jufaan wa 'amma ma yanfa 'u 'nnasa fayamkuthu fll'ardhi."

KORAN, chap. 13.

"He sendeth down the rain from hearen: then flow the torrents in their due measure, and the flood beareth along a swelling foam and out of that ore which they ignite in the fire for the sake of ornaments or utensils a like scum ariseth. In this way ooth God depict truth and falsehood. As to the scum it passeth off like froth, and as to what is useful to man, it remaineth on the earth."

(RODWELL).

“'Aqallu jibali 'l'ardbi turun wa'innahu la'adhamu inda 'llahi qadran wa manzilan."

Gunstax, Book I.

"Least of earth's mountains is Sinai, yet all

In worth and rank with God beneath it fall."

EASTWICK. 
“'Ara'aita mani 'ttakhadh' ilahahu hawahu afa'anta takunu 'alaihi wakila. Am tahsabu anna aksarahum yasma'auna au y'aqiluna, in hum illa ka'la'n'aami bal hum a'dhallu sabila." Koran, chap. 25.

"What thinkest thou of him who taketh his passions for his God, wilt thou then be a guardian over him? Thinkest thou that the greater part of them hear or understand. Verily, they are just like the brutes. Yea, they stray even further from the right way." Rowwei.l.

“'Ara'aita 'lladhi yukadhdhibu bi'ddin, fadhalika yadu'u 'lyatim wa la yahudhdhu ala ta'ami 'lmiskin, fawailun lilmusallin, 'lladhina hum 'an salatihim saahun, 'lladhina hum yuraaun, wa yamna'un 'Ima'un."

KoRAN, chap. Iо7. 1-7

"What thinkest thou of him who treateth the day of judgment as a lie? $\mathrm{He}$ it is who thrusteth away the orphan, and stirreth not others up to feed the poor. Woe then to those who pray, who in their prayer are careless, who make a show of devotion, but refuse help to the needy."

(RODWELL).

"'Ara'aitum in asbaha ma'aukum ghauran, faman yatikum bima'in ma'in."

Koran, chap. 67.

"What think ye? If at early morn your waters have sunk away, who then will give you clear unning water?" (RoDwELL).

“'Ara'aitum in ja'ala 'llahu alaikumu 'llaila sarmadan ila yaumi 'lqiyamati man ilahun ghairu 'llahi y'atikum bidhiain 'afala tasma'un." KORAN, chap. 28.

"What think ye. If God should make it one long night for you until the day of resurrection, what god but God could bring you light? Will ye not then hearken?"

RODWELI.

" 'Arabra ki bar Dijla bashad qu'ud

Che gham darad az tishnagan-i-Zarud?"

BOSTAN OF S'ADI, chap. 8.

"To the Arab who is sitting by the Tigris

What care is there as to the thirsty ones of the desert of Zarud ?"

(Clarke).

"Are! alam khiyal ast, wale

Paiwasta dar u haqiqa'e jalwagar ast."

SUbahani.

"In truth the world is an illusion; however Certainty is for ever displaying her effulgence there."

(SHEA).

"Ar-rahil! ar-rahil! fa lam yabka mina 'lumrin illa qalilun, wa baina yadeika 'ssafaru 'ttawilun, wa jam'i ma anta flhi mina 'lamli wa 'ilmi riya wa takhilun."

GHAZZALI.

"Up ! up ! only a little life is left, and the road before thee is long and thou art immersed in illusion." 
“Arrahmanu 'allama 'iquran, khalaqa 'linsan, allamahu 'Ibayan A'shshamsu wa'lqamaru bihusbanl wa'lnajmu washshajaru yasjudani wa'ssama rafa'aha wawadha'a 'lmizan, a'lla tatghau fi lmizan wa'qinu 'Iwazna bi'lqisti wa la tukhsiru 'Imizan wa'lardha wadha'aha lila'nam, flha fakihatun wa'innakhlu dhatu la'kmam wa'lhabbu dhu'l'asfi wa'irraihan fabiaiyya ala' rabbikuma tukadhiban?'

Koras, chap. 55 .

"The (jod of mercy hath taught the Koran, hath created man, hath taught him articulate speech. The sun and the moon have each their times and the plants and the trees bend in adoration. And the heaven He hath reared it on high; and He hath appointed the balance, that in the balance ye should not transgress; weigh therefore with fairness and scant not the balance. And the earth He hath prepared for mankind, therein are fruits and palms with sheathed clusters, and the grain with its busks and the suppurts of life. (Which then of the bounties of your Lord will ye deny?

ROINELL.

“'Arrijalu quwwamuna ala 'nnisa'i bima fadhdhala 'llahu ba'dhahum ala ba'dhin wa bima 'anfaqu min 'amwalihim."

KORAN, chap. 4. $\mathrm{V} \cdot 38$

"Men are superior to women on account of the qualities with which God hath gifted the one above the other and on account of the outlay they make from their substance for them."

(RODWELL).

"Asa'an takrahu shai'an wa huwa khairun lakum wa'asa 'an tuhibbu shai'an wa huwa sharrun lakum wa' llahu ya lamu wa'antum la ta'lamun."

Koran, chap. 2.

"Haply ye are averse from a thing though it be good for you, and haply ye love a thing though it be bad for you. And God knoweth but ye know not."

(RODWELL).

"Asaish-i-do giti tafsir-i-in do harf ast

Ba dostan talattuf, ba dushmanan mudara." Hafiz ODE, 6.

"What holds in peace this two-fold world, let this two-fold sentence show

Amity to every friend, courtesy to every foe." BICKNELL.

“'Asalatu 'rrai sanatani 'ani' lkhatali

Wa hilujatu 'lfadhli zanatani laday 'l'atali ;

Majdi akhiran wa majdi 'awwalan sharaun

Wa'shshamsu ra'da 'dhdhuha ka'shshamsi fi'ttafali."

" No kind supporting hand I meet

A. Tugra.

But fortitude shall stay my feet,

No borrowed splendours round me shine

But virtue's lustre all is mine;

A fame unsullied still I boast

Obscur'd, concealed, but never lost

The same bright orb that led the day

Pours from the west his mellow ray." J. D. Carlyl.E. 
" Asan mi-namud awwal gham-i-darya ba bui sud Ghalt guftam ki in tufan ba sad gauhar na mi-arzad."

ANwar-I-SuhEILI.

"Light at first the toil of ocean seemed in hope of future gain ;

I did mistake ; a hundred jewels are not worth one hurricane."

Eastwick.

" 'Ashahidu man 'ahwa baghairi wasiiatin

Fayalhaquni sha'nun 'adhallu tariqa;

Yuwajjiju naran thumma yutfl barashshatin

Li dhalika tarani muhraqan wa ghariqa."

Gulistan, chap. 2.

"I'll with unintercepted gaze survey

Him whom I love, and wildered, lose my way.

One while a flame he kindles, bright in vain

For soon He quenches it with cooling rain;

'Tis thus thou seest me burnt, then drowned again."

(EASTIVICK).

"Ashiq shahinshahast do "alam bar u nisar

Hich iltifat-i-shah basue nisar nest;

'Ishq ast wa 'ashiq ast ki baqist ta abad;

Dil juz barin manib ki bajuz musta'ar nest."

Diwan-I-Shams-I-Tabriz.

"The lover is a monarch; two worlds lie at his feet;

The king pays no heed to what lies at his feet;

'Tis love and the lover that live to all eternity

Set not thy heart on aught else ; tis only burrowed."

(NicholsoN).

" "Asian az gunah tauba kunand

"Arifan az "ibadat istighfar."

Gulistan, chap. 2.

" Sinners of sin repent; but those who have

Knowledge of the Most High, at pardon aim

"For worthless worship which they view with shame."

(EAS'TWICK).

“ Asi-j-kina dozakh ast wa kin-i-tu

Juzu an kull ast wa khasm-i-din-i-tu

Chun tu juzu dozakhi, hin, gosh dar;

Juzu sue kull-i-khud girad qarar ;

War tu juzu jannati' ey namdar,

Alsh tu bashad chu jannat paedar."

Jalaluddin Rum.

" "The root of hatred is hell and that hate of yours

Is a part of that whole and is the foe of your religion

Since you are a part of hell, beware!

For the part ever tends towards its whole

But if you are a portion of heaven, $\mathrm{O}$ renowned one,

Your joy will be as lasting as heaven itself." 
- Asp-1-laghar mlyan ba kar ayad Roz-i-maidan na gao-i-parwari."

"The slender courser in the battle day, will the fat stall-fed ox outvalue far."

Eastwick.

"Asp-i-tazl do tag rawad ba shitab

Ushtur ahista mirawad shab wa roz."

Guilstas, chap. 6.

"Two courses may be sped by charger hot,

The camel goes slowly but gous day and night."

(EAstrick).

“Asrar-i-azalra na tu dani wa na man

Wa in harf-i-mu'amma na tu khwani wa na man

Hast az pas-i-purda guftogu-i-man wa tu

Chun parda bar uftad na tu mani wa na man." O.mar Khavvan.

"Nor you nor I can read the etern decree

To that enigma we can find no key

They talk of you and me behind the veil

But if the veil be lifterl, where are we?"

(INHINFIELD).

"Asta'iz Allah min Shaitanihi

Qad halaqna' ah 'min tughianihi ;

Yak sag ast wa dar hazaran mirawad

Har ki dar wai raft u an mishawad.

Har ki sardat kard medan ki dar ust

Div pinhan gashta andar zer post;

Chun niyabad surat, ayad dar khiyal,

Ta kashanad an khiyalat dar wabal."

JALALUdDIN RUMI.

" Let us seek refuge with Allah from Satan;

Alas! we are perishing from his insolence.

The dog is one yet he enters a thousand forms :

Whatever he enters, straight becomes himself;

Whatever makes you shiver, know he is in it,

The Devil is hidden beneath its outward form.

When he finds no form at hand, he enters your thoughts

To cause them to draw you into sin."

(WHINFIELD).

"'Astaqim, fa'l'udu tanmi 'uruquhu

Qawiman wa yaghshahu Idha ma 'ltawa 'ttawa

Wa la tut' 'l'hirsa 'Imudhilla, wa kun fatan,

Idha 'Itahabat 'ahsha'u bi'ttawa, tawa,

Wa "asi 'lhawa 'Imurdi fakam min muhalliqin

'Ila 'nnajmi lamma 'an 'ata'a 'lhawa, hawa." 
"Be upright, for the straight tree will spread its roots, whereas when it grows crooked, it speedily pines away.

Ohey not abasing greed, but behave as a man who bears in silence the pangs of hunger that gnaw at his vital parts ;

And battle against lusts that destroy thee, for many who had soared to the stars, enslaved by lust, fell and came to grief." (STEINGASS).

"'Atadhunnu an satanfa'uka haluka, idha ana irtihaluka, au yunqidhuka maluka, bina tubiquka amaluka, au yughni anka nadamuka, idha zallat qadamuka, au ya'tifu aleika ma'sharuka, yauma yadhumuka mahsharuka."

Hariki Maqanat, .

" Thinkest thou that thy state will profit thee when thy departure draweth near? or that thy wealth will deliver thee when thy deeds destroy thee? or that thy repentance will suffice for thee when thy foot slippeth, or that thy kindred will lean to thee in the day that thy judgment-place gathereth thee?"

CHENERY.

“'At'amuruna 'nnasa bi'lbirri watansauna 'anfusakum wa'antum tatluna 'lkitaba, 'afala ta'qilun? wa'sta'inu bi'ssabri wa'ssalati wainnaha lakabiratun illa "ala 'lkhash'iyin."

KORAN, chap. 2.

"Will ye enjoin what is right upon others, and, though ye read the Book, forget your own souls? Will ye not then understand? And seek help with patience and prayer; and a hard duty indeed is this but not to the humble."

(RODWELL).

"Atishe ra ki sokht khalqe az an

Juz bakushtan "ilaj natawan kard."

Anwar-i-Suheili.

"To quench the spark is thy sole course to end

A flame which would o'er heaven and earth extend."

" 'Atish suzan nakunad ba sipand

EASTWICK.

Anche kunad dud-i-dil-i-dardmand."

Gulistan, chap. .

"Flames cannot with such speed wild rue consume

As tyrants perish by the wronged heart's fume."

" Atsar-i-mardam chu bugzasht az yake

(EASTWICK).

Bashad an az f'il-i-shaitan be shake

Khun bini niz az shaitan buwad

Anki zahir dushman-i-insan buwad;

Khamiaza f'il-i-shaitanast wa qai

Ey pisar, aiman mabash az makar-i-way."

Fariddudin Attar.

"The sneezing of a man if it exceed one sneeze

Is without doubt one of the devil's works

The flowing of blood from the nose likewise proceeds from Satan

Ife who is the manifest enemy of mankind

Yawning is his work and also vomiting

O young man be not off thy guard against his deceit." (OUSEleY). 
"Audhu b'lliahl mina 'lfagri 'lmuqibbu wa mujawarati man la uhibbu."

Provern.

"God defend me from humiliating poverty and from the neighbourhood of one I do not love."

(EAstwick).

" 'Aud'u rabbakum tadharru'an wa khuflyatan innahu la yuhibbu 'Imu'tadin."

KorAx, chap. 7 .

"Call upon your Lorl humbly and in secret for He loveth not the transgressors.")

(MUIR).

"Au kasayyibin mina 'ssama'i fihi dhulumatun wara'adun wa baraqun yaj'aluna 'asabi'ahum fl adhanlhim mina 'ssawa'iqi hadhara 'lmauti wa 'llahu muhitun bi'lkaflin."

KorAx, chap. 2.

"Like those who, when there cometh a storm-cloud out of the heaven, big with darkness, thunder and lightning, thrust their fingers into their ears, because of the thunder clap, for fear of death ! and God is round alout the unbelievers."

(RODWELL).

“' 'Auma tara 'lmahbuba w'almakruha luzza fl namat K'ashshauki yabdu fl'lghusuni ma'a'ljaniyy 'lmultaqat? Wa lau antaqadtta ban' 'zzamanl wajadtta aktharaham saqat."

Maganat of Hakiri (21).

" Dost thou not see the loved and the hated linked together in one class As the thorn comes forth on the branches with the fruit that is gathered, If thou wilt examine well the sons of the time, thou wilt find the most of them but refuse."

(ChENeRY).

"Aurad baztarabam awwal bawujud

Juz hairatam az hayat chize nafzud;

Raftem baikrah wa nadanem che bud

Za in amadan wa raftan wa budan maqsud." OMAR KHAYYan.

"He hrought me hither to my great surprise

From life I gather but a dark surmise ;

I go perforce. Why come? Why live? Why go?

I ask these questions, but find no replies."

'Awa 'dhdh'ibu f'astanistu bi'dhdhibi idh 'awa

Wa sawwata insanu fakadtu atiru."

(ANON).

"When the wolf howls and whines, it sounds familiar; but if a man makes a noise I feel scared."

"Awala yarauna 'annahum yuftanuna fl kulli 'amin marratan au marrataini, thumma la yatubuna wa la hum yadhdhakkarun."

KORAN, chap. 9 .

"Do they not see that they are provecl every year once or twice? Yet they turn not neither are they warned."

(RoDUtrLI.). 
“'Awalam yara 'llinsanu anna khalaqnahu min nutfatin faidha huwa khasimun mubin, wa dharaba lana mathalan, qala man yuhi 'I'adhama wahia ramim. Qul yuhiyiha 'lladhanshaha awwala marratin wa huwa bikulli khalqin "alim."

KoKAN, chap. 36 .

"Doth not man perceive that we have created him of seed? Yet lo! he is an open caviller: and he meeteth us with arguments "Who" saith he "shall give life to bones when rotten? Say " $\mathrm{He}$ shall give life to them who gave them being at first, for in all creation is He skilled."

(ROINELL.).

"'Awalam yara 'lladhina kafaru anna 'ssamawati wa'l'ardha kanata ratqan fafataqnahuma wa ja'alna min'lmaai kulla shayan hayyin, 'afala yuminun."

KoRAN, chap. 21 .

"Do not the unbelievers see that the heavens and the earth were both a solid mass, that then we clave them asunder and that by means of water we gave life to everything? Will they not then believe?" Ronwelt.

\section{“Awaz-i-sagan kam na kunad rizq-i-gudara."}

URFI.

" The dogs' barking does not diminish the beggar's bread."

“'Ayahsabu 'linsanu an yutraka suda? alam yaku nutfatan min mantyyin yumna, thumma kana 'alaqatan fakhalaqa fasawwa, faja'ala minhu 'zzaujaini, 'Idhdhakara wa'lunsa, alaisa dhalika biqadarin "ala an yuhiya 'lmauta?"

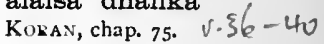

"Doth man think that he will be left alone? Was he not a mere embryo, then he became thick blood, of which God, formed him and fashioned hin ; and made him twain male and female. Is He not powerful enough to quicken the dead?"

(RODWELL).

“'Ayawaddu 'ahadukum 'an takuna lahu jannatun min nakhilin wa' a'nabin tajri min tahtiha 'nnharu, lahu fiha min kulli 'ththamarati wa'asabahu 'lkibaru wa lahu dhurriyyatun dhu'afau fa'asabaha 1'sarun flhi narun fa' htaraqat kadhalika yubayyinu 'llahu lakumu 'layati la'allakum tatafakkarun."

KorAN, chap. 2.

Doth any of you desire to have for himself a garden of date trees and vines, with water courses running through it, wherein he shall have all kinds of fruit, and that he should reach old age, and have a weak offspring ; then shall a fiery wind strike it and it shall be burnt up. Thus doth God show His signs unto you that ye may consiler."

\footnotetext{
“'Aynama takunu, yudrikkumu 'Imautu wa lau kuntum fi burujin mushayyadatin."

Koran, chap. 4. V. 80 towers."

"Wherever ye be, death will overtake you, thuugh ye lie in lofty RODWELL.
} 
"Ayyatuha 'nnafsu 'Imutma'innatu, irji' ila rabbiki radhiatan mardhiyyatan, fa'dkhuli fl 'ibadi, wa'dkhuli jannati."

$$
\text { KORAN, chap. \&g. }
$$

"Oh, thou soul which art at rest, return to thy Lord well-pleased and pleasing Him: enter thou among my servants, and enter thou my paradise."

(RODWEL.I.).

" Ayyuha 'lmuddaththir, qum fa' andhir, wa rabbaka fakabbir wa thiabaka fatahhir wa'rrujza fahjur, wa la tamnun tastakthir, wa lirabbika fa'sbir."

KORAN, chap. 74.

"O thou enwrapped in thy mantle! arise and warn! and thy Lordmagnify Him, and thy raiment-purify it, aud the abomination-flee it, and bestow not favours that thou mayest receive again with increase, and for thy Lord wait thou patiently."

(KODWELL.).

"Azada ta tawanad az qaid-i-tan bar ayad

Az post gar na bashad az pairahan bar ayad."

Sarabl.

"The truly free as soon as possible disengages himself from bolly

If he cannot extricate himself from skin, let him resign his doublet."

"Az amadan wa raftan-1 ma sudi $k u$,

SHEA.

Wa za tar-i wujud-umr-i-pa pudi ku,

Dar chambar-1-charkh jism-t-chandín pakan

Misuzad wa khak mishawad, dudi ku."

Onak Khayyam.

"We come and go, but for the gain, where is it?

And spin life's woof, but for the warp, where is it?

And many a righteous man has burned to dust

In heaven's blue rondure, but their smoke where is it?"

(WHINFIEI.D).

“ Az an k'az tu tarsad bitars, ey hakim, Wa gar ba chu u sad bara'e bajang."

Gulistan, chap. I.

"O wise man fear him who fears thee, even though thou couldst be successful in the contest with a hundred such as he."

"Az bugzar wa padshahi kun;

Gardan-i-be tam'a buland shawad."

Gulistan, chap. 3 .

"Quit greed and as a monarch reign

For proud his station who for nothing hopes."

"Az malaik bahra dari w'az bahaim niz ham;

(EASTWICK). Bugzar az hazz-i-bahaim k'az malaik bugzari."

AкHLa!-I-MUhsin.

"Thou hast a portion with the angels and likewise with the brutes

Pass on from the pleasure of animals that thou mayest excel the angels."

(KEENE). 
"Az rafta qalam hich digar gun na shawad Wa za khurdan gham bajuz jigar-khun na shawad Gar dar hama umr-i-khwesh khunaba khuri, Ek qatra az an ki hast afzun na shawad."

Omar Khayyam.

" Man cannot change what pen hath writ of yore, 1)iet of sorrow breedeth heart-pang sore ; Spend thy whole life in shedding tears of blood, Thou can'st not add one tear-drop to thy store."

(WHINFIELD).

" Az sadaf yad gir nuqta'e hilm

Har ki burrad sarat, gauhar bakhshash."

HAFIZ.

"Learn meekness from the shell in ocean's bed And pearls on one who wounds thy head bestow."

(BICKNELL).

"Az tawakkul dar sabab kahil mashau

Ramaz 'al kasib habib ullah' shanau

Gar tawakkul mi-kuni dar kar kun

Kasb kun, pas takiya bar jabbar kun."

ANWAR-I-SUheILI.

" Do not, to slothfulness, on God depend, The saying hear, "Who labours is God's friend." With labour be combined thy confidence

And, while thou toilest, trust Omnipotence." EAsTwick.

"Ba barf ab-i-rahmat makun bar khasis,

Chu kardi, mukafat bar yakh nawis."

Bostan OF S'ADl.

"Use not mercy with ice-water towards the mean,

When thou dost - write the compensation for it on ice."

(CLARKE).

" Ba chunan galib khudawande kase

Chun na mirad gar na bashad u khase."

Jalaluddin Rum.

"For love of our Almighty God, the Lord of all,

Who would not die ; a stock, a block, we needs must call."

(REDhouse).

"Ba darya dar manaf'i beshumarand

Wa gar khwahi salamat, bar kinarast."

Gulistan, chap. $\mathbf{r}$.

"Upon the sea, 'tis true is boundless gain

Wouldst thou be safe, upon the shore remain."

(EASTWICK).

"Badbakht kase ki sar bitabad

Z'in dar ki dar-i-digar na yabad."

Gulistan.

" Ill-fated is he who turns from this door, for he will find no other." 
"Ba yak natarashida dar majlis Biranjad dil-i-hoshmandan basi ; Agar birka'e pur kunand az guiab Sage dar wai uftad, kunad manjalab."

Gulistan, chap. 2.

" lie there but one rough person in their train For his misdeeds the wise will suffer pain. Should you a cistern with rose-water fill A dog dropped in it would defile it still."

"Ba hangam-i-sakhte ma shu na-ummed K'az abr siyah barad ab-i-sufed."

Nizami.

"In the hour of adversity be not without hope For crystal rain falls from black clouds." OUSELEY.

" Bahistagi kar-i-'alam barar,

Ki dar kar garmi ni ayad bakar ;

Chiragh ar bagarmi na afrokhti

Na khud ra na parwana ra sokhti

Shikib awarad bandha ra kalid ;

Shikibanda ra kas pasheman na did."

ANWAR-I.SUHEILI.

"Be thou sedate in what thou hast to do

For fiery haste will prove abortive too

Did not the lamp so hot itself illume

'liwould not its substance and the moth consume

Patience supplies to every ward its key

One ne'er did patient men regretful see."

EASTWICK.

"Ba hukm-i-khuda chun kase uftad

Hama alamash pae ba sar nihand;

Chu binand k'iqbal dastash girift

Sitaish kunan bar bar nihand."

Gulistan, chap. I.

"When one has fallen by high heaven's decree

The banded world will trample on his head;

Then fawn and fold their hands respectfully

When they behold his steps by fortune led."

" $\mathrm{Ba}$ in do sih nadan ki jahandaranand,

Az jahl kd dana-e-jahan and;

Khushbash ki az khurrami, eshan bamisal,

Har k'u na khar ast, kafirash midanand."

Omar Khayyam.

"These fools by dint of ignorance most crass,

Think they in wisdom all mankind surpass ;

And glibly do they damin as infidel

Each one who is not, like themselves, an ass."

(WHINFIEI.D). 
"Bakht wa daulat ba kardani nest, Juz ba tayid-i-asmani nest ; Uftad ast dar jahan bisyar Be tamiz arjumand wa aqil khwar; Kimiagar ba ghussa murda wa ranj, Ablah andar kharaba yafta ganj."

Gulistan, Book r.

" Fortune and wealth are not to merit given, None can obtain them but by aid from heaven ;

In this world oft a marvel meets our eyes

The undiscerning honoured, scorned the wise ;

The alchemist expires with grief and vain

And fools a treasure neath a shed obtain." (EAsTwICK).

" Balagha 'l'ula bikamalihi,

Kashafa 'dduja bi jamalihi,

Hasunat jami'u khisalihi ;

Salla "alaihi wa alihi."

Gulistan, Preface.

"All perfect he * and therefore won

His lofty place and like a sun

His beauty lighted up the night.

Fair are his virtues all and bright.

Let peace and benediction be

On him and his posterity."

(EASTWICK).

"Bani Adam a'zae yakdigar and,

Ki dar afrinish za yak jauhar and,

Chu 'uzui badard aurad rozgar

Digar uzuhara namanad qarar;

Tu k'az mihnat-i-digaran be-ghami,

Nashayad ki namat nihand admi."

Gulistan, chap. $x$.

" All Adam's race are members of one frame

Since all at first from the same essence came ;

When by hard fortune one limb is oppressed

The other members lose their wonted rest :

If thou feel'st not for others' misery,

A son of Adam is no name for thee.

(EASTWICK).

“ Ba nizd-i-dana ni'amat an ast,

K'azu janat buwad jawid masrur ;

Za sim wa zar ki chun gorat buwad jae

Bimand hamchu sangat bar sar-i-gor."

Jami, Biharistan.

"A wise man considers that a blessing

Which rejoices the heart for ever and ever,

The tomb will he thy resting place; hence silver and gold

Will remain on the top of it like stones."

(REHATSEK).

* Muhammad. 
"Bar dukhta am dida chu baz az hama "alam,

Ta didae' man bar rukh-1-zeba'e tu bazast."

HAFIZ.

"I have shut my eye like a falcon to a'l the world

Since my (inward) eye is open to thy beauteous countenance."

(Nicholsos).

"Barozgar-i-salamat shikastagan daryab,

Ki jabr-i-khatir-1-miskin bala bigardanad;

Chu sa'll az tu bazari talab kunad chize,

Bidih, wagarna sitamgar baroz bistanad."

Gulistran, chap. 2.

" In prosperous days go seek out the distressed

The poor man's prayer can change misfortune's course ;

Give, when the begyar humbly makes request

Lest the oppressor take from thee by force."

(EAstivick).

"Bas gul shigufta mi-shawad in baghra, wale

Kas bebala'e khar na chidast azu gule."

HaFiz.

"Though many a rose in this garden is born

No mortal who culls one escapes from the thorn."

Bicknel.t.

" Bas gurusna khuft wa kas na danist ki kist

Bas jan balab amad ki baru kas nagrist."

Gulistan, chap. 1 .

"Full many a starving wight has died unknown

Full many a spirit fled that none bemoan."

(EASTWICK).

"Bash chun dulab nalan chashmtar

Ta za sahn janat baroiad hazar ;

Rahm khwahi, rahm kun ba ishkbar,

Rahm khwahi, bar zaifan rahmat ar."

Jalaluddin Revi.

"Initate the water-wheel that groans and weeps;

By prayers and groans and tears a man his heart pure keeps ;

Wouldst thou shed tears? Feel pity when thou meetest woe,

Wouldst mercy find? Show nercy, when men bow them low."

(REDHOUSE).

"Bas ki dar khak tandurustanra

Dafan kardand wa zakhm khurda na murd." Gulistan, chap. 2.

"Oft have they laid the vigorous neath the clay,

While the sore-wounded have revived at last."

(EAstwick). 
"Bas namwar bazer-i-zamin dafan karda and, K'az hastiyash ba ru-e-zamin yak nishan namand ;

Wa an pir lashara ki sipurdand zer-i-khak

Khakash chunan bikhurad k'azu ustukhan namand;

Zindast nam-i-farrukh-i-Nushirwan ba-adi,

Garchi basi guzasht ki Nushirwan namand;

Khairi kun, ai fulan, wa ghanimat shumar umr,

Z'an peshtar ki bang bar ayad "fulan namand'." Gulistan, chap. I.

" Full many a chief of glorious name beneath the ground now buried lies, Yet not one token of his fame, on earth's wide surface meets our eyes. That aged form of life bereft which to earth's keeping they commit The soil devours, no bone is left, no trace remains to tell of it ;

The glorious name of Nushirwan lives in his deeds year after year ; Do good my friend and look upon this life as an occasion dear

For acting well ere yet we hear of thee that thy career is done."

(EAST'NICK).

" Bas sitare atish az ahan jahid

Wa in dil shorida pazaraft wa kashid ;

Lek dar zulmat yak duzde nihan

Minihad angusht bar astaragan;

Mikushad astaraganra yak ba yak

Taki nafrozad chiraghe bar falak;

Chun inayatat shawad ba ma muqim

Kai buad bimi az an div laim;

Gar hazaran dam bashad har qadam,

Chun tu ba ma'i na bashad hich gham."

JALALUDDIN RUMi.

" How many sparks of fire from flint and steel have flown

How many hearts like tinder, make those sparks their own.

But in the dark some thief his finger presses there

And every train puts out that has been lighted here.

Extinguished if those sparks were not, a flame would rise

A burning light be kindled, flashing beyond the skies

A thousand snares are laid to catch our tripping feet

But Lord, if thou us shield, harm never shall us meet.

If but Thy grace will guide us, lead us on our way,

No thief can steal our peace of mind, our light of day."

(REDHovse).

" Batil ast an ki mudd'ai goyad

'Khufta ra khufta kai kunad bedar?'

Mard bayad ki girad andar gush,

War nawishtast pand bar diwar."

Gulistan, chap. 2.

"Futile is the objector's scorning

'Sleepers ine not slumber's eye.'

Heed then well the words of warning

Though on a wall thou them descry."

Eastwick. 
"Batin-1-ma chu falak ta bi-abad mustaghna ast

Garchi roze do sih dar naqsh wa nigar-i-basharem."

DIWAN-I-SIIAMS-I-TABRIZ.

"Our celestial spirit is free to eternity,

Although for a short time we are iniprisoned in forms of flesh."

"Ba tu bakharabat agar goyem raz

Bih z'anki kunam be tu ba mihrab namaz;

Ey awwal wa akhir-i-hama khalqan tu

Khwahi tu mara bisoz wa khwahi binawaz." OMaR KHAYyas

"In taverns hetler far commune with Thee

Than pray in mosques and fail Thy face to see !

$O$ first and last of all thy creatures Thou,

"Tis thine to burn and thine to cherish me." WhiNrield.

" Ba tu dozakh jannat ast, ey jan faza

Ba tu zindan gulshanast, ey dilbara."

Jalaluddin Rumi.

"With thee hell would be a mansion of delight

With thee a prison would be a rose garden."

WHINFIELD.

" Ba tu mara sokhtan andar 'azab

Bih ki shudan ba digare dar bihisht;

Bue piyaz az dihan-1-khubrue

Naghzaztar ayad ki gul az dast-i-zisht."

Gulistan, chap. 6 .

" Hetter with thee le tortured and consume,

Than with another Eden's bowers possess :

More sweet from beauty's mouth the onion's fume

. Than roses from the hand of ugliness." (EAstwick).

"Ba tu za ziyan che bak darem

Ey sud kuni hama ziyanha?"

(DIWAN-I-SHAML-1-TAERIz).

"With thee how should we be afraid of loss

O thou, who turnest every loss to gain." (Nicholso. $)$.

"Ba'uzr wa tauba tawan rastan az "azab-j-khuda,

Walek mi natawan az zaban-i-mardum rast." Gulstav, chap. 2.

" By penitence thou mayest exempted be

From wrath divine ; man's tongue thou cannot flee."

(EAstwick).

"Ba waqt nafaz-i-qaza wa qadr

Hama zirakan kur gardand wa kar."

ANWAR-I-SuHEILs.

"When heaven's decree and fate's commands are sped

The wise are blinded and their ears grow dead."

Eastwick. 
"Ba was'at-i-ardhi 'llah dar habas che khuspidi?"

DIWAN-I-SHaMISI-TABRI\%,

"Why, when God's earth is so wide, have you fallen asleep in a prison?" when God's earth is so wide, have you fallen asleep in a

"Bazikrash har che bini dar khurushast

Dili danad dar in m'ana ki gushast;

Na bulbul bar gulash tasbih khwanist,

Ki har khari batasbihash zabanist."

Gulistan, chap. 2.

"All things thou seest still declare His praise

The attentive heart can hear their secret lays.

Hymns to the rose the nightingale His name

Each thorn's a tongue His marvels to proclaim."

(EASTWICK).

"Be abr mushkil ast tamasha'e aftab, Saib nazara rukh-i-u dar niqab kun."

SAIB.

"It is difficult to gaze on the sun without a cloud

View therefore, O Saib, the face of thy beloved through her veil."

(OUSELEY).

" Begana agar wafa kunad khwesh-i-man ast

War khwesh khata kunad, badandesh-i-man ast ;

Gar zahr muwaflqat kunad, tiryakast,

War nosh mukhalifat kunad, nish-i-man ast." OMAR KhaYYa.u.

"Is a friend faithless? Spurn him as a foe, But on trustworthy foes respect bestow, Hold healing poison for an antidote, And baneful sweets for deadly eisel know."

(WhINFIELD).

"Be guft wa gui zulf-i-tu dil-ra hame kashad

Ba zulf-i-dilkash-i-tu kira guft wa gu'st."

HAFIZ,

" Thy curl is ever drawing the heart silently

Who hath power to speak (quarrel) with Thy heart-vanishing curl."

(NICHOLSON).

"Beshtar ashab jannat ablahand,

Ta za sharr failsufl mirihand;

Khwesh-ra "uryan kun az jumla fazul,

Tark khud kun ta kunad rahmat nazul."

JaLALUDDIN RUM.

"The majority of those in Paradise are the simple

Who have escaped the snares of philosophy,

Strip yourself bare of overweening intellect

That grace may ever be shed upon you from above."

(WHINFIELD). 
"Bewafai chun saganra "ar bud

Bewafai chun rawadari namud

Haqq Taaia fakhr aurad az wafa

Guft "man aufa ba ahd ghairana?'"

Jalaluddin Rum.

"Whereas want of fidelity is shameful even in dogs,

How can it be right in men?

God Almighty Himself nakes boast of fidelity

Saying "Who is more faithful to his promise than we?"

(WHINFIELD).

" Bi bazi na guft in sukhan Bayazid,

Ki az munkir aimantar am k'az murid." BOSTAN of S'ADI (chap. 5).

"Bayazid uttered, not in sport this speech

"I am safer from the disbeliever, than from the disciple."

(CLARKE).

" Bi-bin an be-hamiyatra ki hargiz

Nakhwahad did ru-e-nek bakhti,

Tan asani guzinad khwishtanra,

Zan wa farzand bugzarad basakhti."

Gulistax, chap. I.

"See now that wretch devoid of shame! for him

Fair fortune's face will smile not, nor has sniled ;

Himself he pampers in each selfish whim

And leaves his hardships to his wife and child."

(EAS'TWICK).

" Bi chashm-i-khwish didam dar bayaban

Ki mard-i-ahista bugzasht az shitaban;

Samand-i-bad pa az tak faru mand,

Shutarban hamchunan ahista mirand."

Gulistan, chap. 8.

"I've in the desert with these eyes beheld

The hurrying pilgrim to the slow-stepped yield;

The rapid courser in the rear remains,

While the slow camel still its step maintains."

EASTW:CK.

" Bi dan ki har ja ki gulast, kharast, wa ba khamar khamar ast wa ba sar-i-ganj mar, wa an ja ki durr-i-shahwarast nihang-i-mardamkhwar ast."

GuLJST A., chap. 7.

" Know that wherever there is a rose there is a thorn, and with wine there is intoxication, and over a treasure is coiled a serpent, and where there are royal pearls these are also devouring monsters." (EASTwICK).

" Bidani gah-i-ghalla bardashtan

Ki susti buwad tukhm na-kashtan."

Bostan of S'ADI, chap. I.

"At the time of corn-gathering thou shalt know

That idleness is not seed-sowing."

(ClARKE). 
"Bi din, ey faromaya, dunya ma khar

Tu khar-ra ba Injil-i-Isa ma khar."

Bostan of S'Adi, chap. 6.

"O one of little worth, buy not the world in exchange for religion;

I'urchase not thou the ass with the gospel of Jesus." (CLARKE).

"Bidozad shara didai hushmand

Dar arad tam'a murgh wa mahi ba band."

Gulistan, chap. 3 .

"The cyes of men though sharp are closed by avarice

Greed will both bird and fish toward the net entice."

(EASTWICK).

"Bigzashtan fursat, ey biradar,

Dar garmravi chu megh bashad;

Daryab ki umr bas aziz ast;

Gar faut shawad, daregh bashad."

HAFIz.

" Opportunity flies, $O$ brother, As the cloud that quick doth pass;

Oh make use of it! life is precious

If we let it go, -alas!"

(BICKNEIL).

"Bikan pumba'e ghaflat az gush-i-hush

Ki az murdagan pandat ayad ba gush." BosTAN OF S'ADr, chap. $\mathrm{t}$.

" Pluck out the cotton of carelessness from the ear of sense

That the advice of dead men may come to thy ear."

(CLARKE).

"Bi khurda tawan atish afrukhtan

Pas anki darakht gashan sukhtan."

Bostan OF S'ADI, chap. r.

"One can light a fire with fragments

Afier that, one can burn the large tree." (CLARKE).

"Bi koshish naroiad gul az shakh-i-bid;

Na zange bigarmaba gardad sufld."

BostAN OF S'ADI, chap. 5 .

"The flower grows not from the willow-bough by effort

The Ethiopian becomes not white by the hot bath."

(Clakke).

"Bi koshish tawan Dijlara pesh bast;

Nashayad zaban-i-bad andesh bast."

Bostan OF $\mathrm{S}^{\prime} \mathrm{Adi}$, chap. 7.

"One can with effort bind the Tigris

One cannot lind the enemy's tongue."

(CLARKE).

"Biksha daram ki dar kushayanda tu'i

Binma raham ki rah numayanda tu'i,

Man dast ba hich dastgiri nadiham,

Ki eshan hama fani and, wa payinda tu'i."

OMar Khayyam. 
"Open the door! O warder best and purest, And guide the way, $O$ thou, of guides the surest ! Directors born of men shall not direct me, Their counsel comes to nought, but thou endurest."

(WIIINFIELD).

"Bikshai du dast-i-khud gar mail-i-kinarastat, Bishkun but-i-khakira ta rue butan bini." Dinan-1-Shasi-I-TAlskiz.

"Open your arms if you desire an embrace,

Iireak the idol of clay that you may behold the face of the fair."

(NiCHOLSON).

"Bi-mir, ey dust, gar khwahi rihai, Ki be murdan na yabi ashnal."

ANWAR-1-SUHEILl.

"Die friend! if thou enfranchisement would gain ; Undying, thou canst not thy friend obtain." EASTwICK.

"Binadan anchunan ruze rasanad, Ki sad dana dar an hairan bamanad."

Gulistix, chap. r.

"Heaven to the fool supplies

Such wealth as would amaze the wise." (EAstwick).

"Bina'e kar ba tadbir bayad,

Ki be tadbir kare bar niayad."

ANwar-1-Suheill.

"On due deliberation base each deed, For unmatured, no plan can e'er succeed."

EASTwick.

" Bina'è ki muhkam na darad asas,

Bulandash ma kun; war kuni, z'u hiras." BostAN OF S'ADI, chap. 2

"The edifice that has not firm foundations

Make it not lofty ; and if thou dost, tremble for it."

(Cl.ARKE).

" Bingar badana dar gil chu bimard, gasht muqbil,

Za 'adam bikard hasil du hazar armaghani,

Za khudi chu u fana shud, gul wa barg mewaha shud,

Za saful bar 'ala shud, bifutuh asmani." Diwan-1-Shams-I-TABriz.

" Earth receires the seed and guards it,

Trustfully it dies :

Then what teeming life rewards it, For self-sacrifice.

With green leaf and clustering blossom

Clad, or golden fruit,

See it from earth's cheerless I osom

Ever sunward shoot."

(FNCONER). 
“ Bingar za saba daman-i-gul chak shuda, Bulbul za jamal-i-gul tarabnak shuda, Dar saya-e-gul nishin ki bisyar in gul Az khak bar amadast wa bar khak shuda."

OMAR KKAYYAM.

" Bulbuls doting on roses oft complain How froward breezes rend their veils in twain Sit we beneath this rose which many a time Has sprung from earth and dropped to earth again."

(WHINFIEI.D).

"Bi qaul-i-dushman paiman-i-dost bishkasti, Bibin ki az ki buridi wa ba ki paiwasti."

GuListan, chap. 8.

"With thy friend thou faith hast broken at the bidding of thy foe,

See with whom thou'st joined alliance, and from whom thou'st sought to go !"

(EAsTwick).

"Biraft shaukat Mahmud wa dar zamana namand Juz in fana ki nashinakht qadr Firdausi."

(JAMI).

"The splendour of the great Mahmud has vanished from the world, and nought remains of him except the tale of his not apprecialing the merit of Firdausi."

(OUSEI.EY).

"Birau, ba dustan asuda binishin,

Chu bini darmiyan-i-dushmanan jang;

Wa gar bini ki baham ek zabanand,

Kaman ra zih kun wa bar bara nih sang." GulisTAN, chap. 8.

"Go! with thy friends sit free from care,

If thou thy foes should see with discord rent.

But if thou mark'st agreement there,

Go string thy bow, thyself prepare,

And pile thy missiles on the battlement." (Easrwick).

"Birau, in dam ba murghe digar nih,

Ki 'anqara buland ast ashiyana."

ANWAR-1-SUhEILI.

"Go! for some other bird these arts apply,

The Anqa has its lofty nest too high." EAstwick.

"Birau zahida, khurda bar ma magir

Ki kar-i-khuda'e na karist khurd."

HAFIC.

"Slight me not zealot, go thou hence ashamed

For naught is slight that has by God been framed."

(BICKNELL).

"Bishau, ai khiradmand, az an dust dast, Ki ba dushmananat buwad ham nishast."

Gulistan, chap. 8. 
"Eschew that friend, if thou art wise, Who consorts with thy enemies."

(EASTWICK).

' Bi shiriu zabani tawan burd gue

Ki paiwasta taikhi burd tund khue

Tu sh!rin zabani za S'adi bigir,

Tursh ruere gu 'bitalkhi bimir.'"

BuSTAN of S'ABI, chap. 4.

"One can by sweet speech carry away the ball of power,

list one of thad disposition constantly endures bitterness;

Take thou from S'adi the pleasant speech;

To the one of litter visage say "Die of bitterness." (Cl.ARKE).

"Bi shirin zabani wa lutf wa khushi

Tawani ki pile ba mue kashi."

ANWAR-1-SUHKILl.

"With honied" tongue and language soft and fair

Theus may'st conduct a manmoth with a hair."

(EASTWICK).

" Bishnau az nai, chun hikayat mikunad,

Az judaiha shikayat mikunad.

K'az naiyistan ta mara biburida and,

Az naflram mard wa zan nalida and.

Sina khwaham sharh sharh az firaq,

Ta baguyam sharh dard-i-ishtyak.

Har kase k'u dur manad az asl-i-khwesh

Baz juyad ruzgar wasl-i-khwesh."

Jalaluddin Rum.

"Hearken to the reed-flute, how it discourses

When complaining of the pains of separation;

- Ever since they tore me from my osier-bed,

My plaintive notes have moved men and women to tears.

I burst my breast striving to give vent to sighs,

And to express the pangs of yearning for my home;

lle who abides far away from his home,

Is ever longing for the day he shall return." (Wuinfiein).

" Bishnau in nukta ki khudra za gham azada kuni

Khun khuri, gar talab ruzi nanihada kuni."

ANWAR-1-SUHEILI.

"Wouldst thou keep thyself from sorrow, then this counsel hear of me Seckst thou that (1) thee unfated, all thy toil will fruitless be."

EASTWICK.

"Bitars az gunahan-i-khwish in nafas

Ki ruz-i-qiyamat na tarsi za kas."

BOSTAN UF S'ABI, chap. 9.

"Be afraid of thy sins this moment

That thou majest fear no one in the judgunent day."

(CI.AKKE). 
"Bitars az khuda wa ma-azar kas Zahi, rastkari hamin ast wa bas."

Anwar-1-Suhieili.

"Fear God nor any living thing distress This is the one sole road to happiness."

EASTWICK.

"Bitarsad anki ba uftadagan na bakhshayad Ki, gar za pai dar ayad, kasash na girad dast." Gulistan, chap. x.

"Who pities not the fallen let him fear Lest, if he fall, no friendly hand be near."

" Bi tundi sabuk dast burd an ba tigh

(EASTWICK). Bi dandan barad pusht-i-dast-i-darigh." Bostan of S'ADI, chap. r.

"With severity to carry a light hand to the sword

Is to carry the hack of the hand of regret to the teeth."

" Biya, biya, ki nayabi chu ma digar yare,

(ClakKe). Chu ma ba jumia jahan khud kujast dildare? Biya, biya, wa bar har sue ruzgar mabar, Ki nest naqd-i-tura pesh-i-ghair bazare." Diwan-I-Shams-I-Tabriz.

" Come, come for you will not find another friend like Me, Where indeed is a Beloved like Me in all the world?

Come, come, and do not spend your life in wandering to and fro, Since there is no market elsewhere for your money."

"Biya ta bar arem daste za dil,

(Nicholson).

Ki natawan baraurd farda za gil ;

Bi fasl-i-khazan mi na bini darakht

Ki be barg manad za sarma'e sakht?

Bar arad tihi dastha'e niyaz

Za rahmat na gardad tihi dast baz."

Bostan of S'Adr, chap. 9.

"Come! let us raise a hand from the heart,

For to-morrow one cannot raise the hand from the clay of the grave;

In the autumn season seest thou not the tree

Which from severe cold remains leafless?

It uplifts the empty hands of supplication,

It returns not through God's mercy, emply-handed." (CLARKE).

" Biya, wa flkrat-i-man kun ki fikratat dadam,

Chu I'al mi-khari az kan-i-man bakharbari ;

Biya wa janib-i-ankas birau ki payat dad, Badu nigar badu dida ki dad didari."

Diwan-I-Shans-1-TABriz.

" Come, and think of $\mathrm{Me}$, Who gave you the faculty of thought,

Since from my mine you may purchase an ass-load of rubies;

Come, advance towards $\mathrm{Him}$ Who gave you a foot,

Look with all your eyes upon Him Who gave you an eye."

(NICHOLSON). 
Biya wa hal-1-ahl-1-dard blshnau,

Ba lufz-1-andak wa m'ana bisyar."

HAF12, ODE, 282.

"Come ! hear of those who have felt sorrow's touch

Their words are few, but what they mean is much."

BICKNELI.

"Biza'at ni-eurdam llla ummed;

Khudaya za 'afu'am makun na-ummed." Bostan of S'ADI, chap. 10.

"I have brought no capital, save hope ;

O God! make me not hopeless of pardon."

" Bustan ba u rawan har ja rawad,

(CLARKE).

Lek an az khalq pinhan mishawad,

Mewaha laba kunan, k'az man bichar,

Ab haiwan amada, k'az man bikhwar."

Jalaludin Rumt.

"That spiritual garden accompanies them everywhere

Vet it is never revealed to the eyes of the people,

Its fruits ever asking to be gathered,

Its fount of life welling up to be drunk." (WHiNfiELD).

"Budem dar zamin wa ghafll az zamin,

Ghafl az ganj ki bud dar wai dafln."

JALALUdDIN RUMI.

"We used to be on the earth, ignorant of the earth, Ignorant of the Ireasure buried within it." (WhINFIELD).

“ Budi tu bulbul-i-masti miyana'e chughdan,

Rasid bui gulistan, ba gulistan rafti,

Base khumar kashidi az in khamir-i-turush,

Ba aqibat ba kharabat-i-jawidan rafti." Diwav-1-Shans-I-TABriz.

"Thou wert a love-lorn nightingale among owls,

The scent of the rose-garden reached thee, and thou didst go to the rose-garden.

Thou didst suffer sore headache from this bitter ferment,

At last thou wentest to the tavern of eternity."

(Nicholson).

"Bugzar az laf-1-aql wa fazl, ki hast

Aql in ja aqila, fazl fazul."

JA.MI.

" Cease to boast of your reason and learning Here reason is a shackle, and learning a folly."

Nicholson.

“' Bugzar az manzil 'ma ' wa 'man,' biguzin ba mulk-i-fana watan, Fa idha fa'alta bimithl dha, falaqad balaghta ba ma tusha."

KURRATU'L ArN.

"The country of 'I' and 'we' forsake; thy home in annihilation make, Since fcaring not this step to take, thou shalt gain the highest felicity."

E. G. Browne. 
"Bugzar za tama" ki afat jan wa dil ast;

Tami ' hama w'az hama kas munf'ilast."

AnwaR-1-Suhe1L.1.

"Quit that pernicious lust of gain for them

Who'n it afflicts, all everywhere contemn."

"Bui mahbub ki bar khak ahabba guzarad,

Che 'ajab agar zinda kunad 'azam-i-ramim."

EASTWICK.

ANwar-1-Suheil.1.

" The scent of the beloved one passed over the lovers' grave

What marvel if to those dry bones the breath of life it gave."

"Bui piyaz az dihan-i-khubrue

EASTWICK.

Naghzaztar ayad ki gul az dast-i-zisht."

Gulistan, chap. 6.

"More sweet from beauty's mouth the onion's fume, Than roses from the hand of ugliness."

EASTWICK.

"Bulandiyat bayad tawaz'a guzin,

Ki an bam-ra nest sullam juz in ;

Za maghrur-i-dunya rah-i-din ma jui

Khuda-bini az khwishtan bin ma jui."

BosTaN OF S'ADI.

"If thou desirest exaltation choose humility; for to that roof there is no ladder save this.

Inquire not the path of religion from him who is puffed up by worldly fortune ; look not for discernment of God from him who sees but himself."

"Bulbula muzhda'e bahar biyar,

Asiatic Journai..

Khabar-i-bad ba bum baz guzar."

Gulistan, chap. 8.

"O nightingale! spring's tidings breathe!

Ill rumours to the owls bequeathe." (EASTwICK).

"Bulbule k'u sitam-i-khar tahammul na kunad, Bihtar an ast ki hargiz sukhan-i-gul na kunad." ANWAR-1-SuHEILI.

"The nightingale that cannot bear the woes

Of the sharp thorn, must speak not of the rose."

"Bulbul ki ba gul dar nigard mast shawad, Sar rishta'e ikhtiyarash az dast shawad."

EASTWICK.

Anwar-i-Suheili.

"The nightingale that views the rose grows blind

And straight lets go the reins that rule the mind."

"Burdbari khazana'e khirad ast;

Har kira hilm nist, div wa dad ast."

EASTWICK.

"Patience is reason's treasury ; we speak

Of brutes and devils when we name the unmeek."

EASTWICK. 
Bute chun bar arad muhhimat-1-kas,

Kl natawanad az khud birandan magas?" BUSTAN IF S“ADI, chap. 10.

"How may an idol accomplish a persun's important affairs

Which camnot drive a fly from its face?"

(CLARKE).

" But khana wa ka'ba khana-e-bandagist,

Naqus zadan tarana- $\theta$-bandagist,

Zunnar wa kalisya wa tasbih wa salib

Haqqa ki hama nishana-e-bandagist."

OMak KHaYray.

"Pagodas like as mosques are homes of prajer,

'Tis prayer that chureh-bells chime into the air;

lea, church and ka'ba, rosary and eross

tre all but divers tongues of world-wide prayer."

"Buwad diwan-i-qurb shah wala,

(WHINIFIELD).

B'an diwan marau bisyar bala,

Ki tarsam chun azan bala waraft,

Za har uftada'e muhkanitar ufti."

JAMI, BнhakISTAX, chap. 3.

"The seat of proximity to the Sultan is high,

Those placed on it are very exalled;

I fear when thou fallest from that height

Thou wilt fall more heavily than all others."

" Buwad khar wa gul baham, ey hoshmand,

Che dar band-i-khar'i? tu guldasta band." BostaN of S'ADI, chap. 7.

"O wise man! the thorn and the rose are together;

Why art thou in the fetter of the th'orn? fasten thou the rose-bouquet."

"Buzurgan chu khur dar hijab uftad

(CI.ARKE).

Hasudan chu akhgar dar ab uftad;

Birun ayad az zer abr aftab

Bi tadrij, wa akhgar bimirad dar ab."

- Bostan of S'Adi, chap. 6.

"Sun-like the great fall under a veil of eclipse, Spark-like the envious fall into the water, The sun comes forth from beneath the cloud

Gradually ; but the spark perishes in the water."

"Buzurgan na kardand dar khud nigah;

Cl.ARKE.

Khuda bini az khwishtan bin ma khwah ;

Tawaz'u sar raf'at afrazadat,

Takabbur bikhak andar andazadat."

Bostan of S'ADI, chap. 4.

"The great showed not regard to themselves

Desire not God-beholding from one self-beholding

Humility exalts the head of thy sublimity,

Arrogance casts thee to the dust."

(CI.ARKE). 
"Buzurgash nakhwanand ahl-i-khirad, Ki nam-i-buzurgan bazishti burd."

Gulistan, chap. .

" Ne'er will he be called great among the wise

Who to the truly great their name denies."

"Chakar-nawazist ki kardast 'ishq-i-tu,

(EASTWICK).

Warna kuja dile ki b'an 'ishq darkhwar ast?

Har dil ki u bikhuft shabe dar hawa'e tu,

Chu ruz-i-rushanast, hawa z'u munawwarast."

Diwan-i-Shams-i-Tabriz.

"'Tis slave-caressing thy love has practised,

Else, where is the heart worthy of that love?

Every heart that has slept one night in thine air

Is like radiant day ; thereby the air is illuminated."

"Chandan bikhuram sharab k'in bu-i-sharab

(NICHOLSON).

Ayad za turab chun rawam zer-i-turab ;

Ta ba sar-i-khak-i-man rasd makhwari

Az bu-i-sharab-i-man shawad mast wa kharab." OMAR KHAyyan.

"So many cups of wine will I consume

Its bouquet shall exhale from out my tomb ;

And every one that passes by shall halt,

And reel and stagger with that mighty fume."

" Chand harfl naqsh kardi az raqum

(WHINFIELD).

Sangha az 'ishq-i-u shud hamchu mum

Z'in haruf shud khirad barik ris,

Naskh mekun ai adib khush nawis,

Dar khur har flkr basta bar 'adam

Dam ba dam naqsh khiyal pur raqam."

Jalaluddin Runi.

" How many letters thou writest with Thy Almighty pen

Through marvelling thereat stones become as wax ;

These letters exercise and perplex reason,

Write on, O skilful Fair-writer,

Imprinting every moment on Not-being the fair forms

Of the world of ideals to confound all thought."

"Chand kardi gird-i-'alam bahri zar

(WhINFIELD).

Bish gardad zar, shawad gham bishtar;

Kasa'e chashm-i-harisan pur na shud,

Ta sadaf qan'i na shud, pur-i-durr na shud." ANwar-r-Suhell.

"How long, gold-seeking round the earth wilt go?

As grows thy treasure, so thy care will grow ;

Nought will the eye-cup of the greedy fill,

Pearls brim the shell but not until 'tis still."

(EASTWICK). 
"Chandin gham-i-behuda makhur shad bazi, Wa andar rah-i-bedad tu badad bezi ; Chun akhir-1-kar in jahan niste ast, Angar ki nisti wa azad bazl."

Onar Khavyan.

" No longer hug your grief and vain despair

But in this unjust world be just and fair And since the substance of the world is naught Deem yourself naught and so shake off dull care."

(WHINFIELD).

"Char chiz ki asl manafl ast wa manal, Niarzad an bachar digar b'akhir hal, Baqa ba talkhi marg, wa amal ba khijlat-i-uzl, Gunah ba sharm-i-nadamat, "ata ba zill-i-suwal." Avwar-I-Suheil.I.

"Four things at first to great advantage tend Yet are not worth four others in the end; life is not worth the woe of dying, nor Will office make thee compensation for The shame of thy displacement, sin weighs not Remorse ; nor can alms gild the beggar's lot."

(EAstwick).

" Charkh na bar be darman mi-zanad, Qafla'e muhtashiman mi-zanad."

ANWAR*1-SUHEILI.

"Heaven does not strike the poor and needy crowd, It strikes the pompous gathering of the proud."

(EASTWICK).

" Chashm-i-man za an sar buwad, wa za 'alam-i-digar buwad, In su jahan, an su jahan, binshasta man bar astan; Bar astan an kas buwad, k'u natiq-i-akhras buwad, In ramz guftan bas buwad, digar magu, dar kash zaban."

Diwan-i-Shame-1-Tabill.

"Mine eye is from that source, and from another universe Here a world and there a world : I am seated on the threshold; On the threshold are they alone, whose eloquence is mute,

"Tis enough to utter this intimation : say no more, draw back thy tongue." (Nicholson).

"Chi 'ajab gar faru rawad nafsash "Andalibe gharab ham qafsash."

Gulistan, chap. 8.

"What marvel if his spirits droop

A nightingale with crows in coop?" (EAstwick).

"Chi bak az mauj-i-bahr an ra ki bashad Nuh kishtiban?"

Gulista.n (Preface).

"What terror where Noah is the pilot, though rages the storm-driven sea?"

(EASTWICK). 
" Chi bude ki dozakh za man pur shudi, Magar digaranra rihai shudi."

Bostan of S'ADI, chap. x.

" How well would it have been, if hell had been full of me, Perhaps for others there might have been escape."

(Clarke).

"Chi danand Jaikunian qadar-i-ab?

Za wamandagan purs dar aftab."

BOSTAN OF S'ADI, chap. 8.

"What do the people of the Jehun river know of the value of water?

Ask those wearied utterly in the sun."

(Clakke).

"Chi danand mardum ki dar jama kist,

Nawisanda danad ki dar nama chist."

Gulistan: chap. 2.

"What know men of the wearer, though they know the dress full well. The letter-writer only can the letter's purport tell." (EAsTIWICK).

"Chi faida zi zirih ba kushad-i-tir-i-qaza?

Chi manfa'at zi sipar ba nafaz-i-hukmi qadr?

Agar zi ahan wa pulad sur-i-hisn kuni,

Hawala chun birasad, zud ajal bikobad dar."

HÅFIZ.

"What serves thy armour 'gainst Fate's arrows fierce?

What serves thy shield if Destiny transpierce?

Though steel and iron may thy ramparts plate

When comes the mandate, Death shall burst thy gate."

(BICKNEI.L).

"Chi gauhare ki kasera bikaf baha'e tu nest?

Jahan che darad dar kaf ki an ata'e tu nest?"

Diwan-1-Shans-1-Tabriz.

"What pearl art thou that none possessetl the price of thee?

What does the world possess that is not thy gift ?"

"Chi khush bashad ki ba'd az intizari,

Ba ummedi rasad ummidwari."

SA'ór.

"How good it is when one with waiting tired Otstaineth that which he hath long desired."

(BROWNE).

" Chi khush guft Firdausi pak zad,

Ki rahmat bar an tarbat pak bad,

'Ma azar mure ki danakash ast,

Ki u niz jan darad wa jan khush ast." BOSTAN of S'ADI, chap. x.

"How well said Firdausi of pure birth

(May mercy be on that pure tomb!)

'Wound not the ant that is the grain carrier

For it also has life, and life is pleasant."' (CLARKE). 
" Chl khush guft zale ba farzand-1-khwish, Chu didash palang afgan wa pil tan,

- Gar az ahd-1-khurdiyat yad amadt,

Ki bichara budi dar aghush-1-man,

$\mathrm{Na}$ kardi dar in roz ba man jafa

Ki tu sher marde wa man pira zan.'"

Guintan, chap. 6.

"Well said that aged mother to her son,

Whose giant arm could well a tiger slay,

'Couldst thou remember days long past and gone

When in nyy arms a helpless infant lay,

And know thyself that babe, thou wouldst not now

Thus wrong me when I'm old, an athlete thou."

"Chi mi-khwahad az ghibat an sada mard,

Ki diwan siyah kard, wa chize na khurd." BOSTAN of S'ADi, chap. 7.

(EASTWICK).

"From slander what does that simpleton desire

Who blackened his record book with God and enjoyed not anything?"

"Chi naghaz amad in nuqta dar Sindbad,

(ClaAk KF).

$\mathrm{Ki}$ ' 'ishq atish ast, ey pisar, pand, bad;'

Ba bad atish tez bartar shawad,

Palang az zadan kinawartar shawad."

Bostan of S'Avi, chap. 3 .

"How pleasantly occurred this witticism in the book 'Sinbad"

'Oh son! love is fire ; advice, wind.'

The fierce fire by the wind beconies more lofty.

The panther by striking becomes more angry."

(Clarke).

"Chi salhae flrawan wa umarhae daraz

K1 khalq bar sar-i-ma bar zamin bikhwahad raft;

Chunanki dast ba dast amadast mulk bama,

Ba dasthae digar hamchunin bikhwahad raft." Gulistan, chap. x.

"Inw long shall men my buried dust tread down

Through many a lenglhening year and distant day.

From hand to hand to me descends this crown,

To others so, it soon will pass away." (EAsTwick).

"Chi sud ar pashimani ayad bar kaf, Chu sarmaya'e umr kardi talaf?"

Bostan of S'Adi, chap. 9.

"What profit if repentance comes to hand,

When thou hast squandered the capital of life?"

"Chi wazn aurad jae amban-i-bad, Ki mizan-i-'adl ast wa diwan-i-dad."

(CLARKE).

"What weight may the leathern bag full of wind show in the place

Where there is the scale of justice and the book of equity?"

(Clakki:). 
"Chi zur aurad panja'e juhd-i-mard Chu bazue tauflq yari nakard."

Bostan of S'Adi, chap. 5.

"What force does the grasp of man's excrtion bring

When the arm of God's grace assists not?" (CLARKE).

"Chiguna bar naparad jan chu az janab-i-jalal, Khitab-i-lutfl chu shakkar ba jan rasad ki, 'ta'al.' "

Diwan-I-Shans-I-Tabriz.

"Why does not the soul take wing when from the glorious presence A speech of sweet favour comes to it saying, "Aloft!"

(Nichoison).

"Chihal sal-i-'umr-i-azizat guzasht, mizaj-i-tu az hal-i-tifli na gasht; Hama ba hawa wa hawas sakhti, dame ba masalih na pardakhti; Ma kun takya bar umr-i-na paedar, mabash aiman az bazi-iruzgar."

Pandnama of S'Adi.

" Forty years of your precious life have elapsed ; your disposition has not altered from the state of childhood. You have done all things through thoughtlessness and vanity. Place not reliance upon perishable life; think not yourself secure from the sport of fortune." (GLADWIN).

"Chira dil bar in karawangah nihem

Ki yaran biraftand wa ma bar rihem?

Pas az ma hamin gul dihad bustan

Nishinand ba yak digar dustan."

BOSTAN OF S'ADI, chap. 9.

Why place we the heart on this caravan place,

From which friends have departed, and we are on the road?

After us (i.e. our death) the garden will give the same rose and friends will sit by one another."

(CLARKE).

"Chiragh pish aftab partaui na darad wa minara'e buland dar daman-i-kuh-i Alwand past numayad."

Gulistan, Preface.

A lamp gives no light in the sun, and a lofty minaret shows low at the foot of Mount Alwand.

(EASTWICK).

"Chiraghe ra ki Izid bar faruzad,

Har an kas paff zanad rishash bi suzad."

Dabistan,

"The lamp which God has lighted whoever blows it out, burns his beard."

(SHEA).

"Chira haqq na me bini ai khud-parast?

Chu ayad bikushidanat pesh chiz,

Bitauflq-i-haqq dan, na az s'ai khwish."

Bos ran OF S'ADI.

"O self-worshipper, why dust thou not see God?

When by thy striving a thing happens

Know by God's grace it is, not by thine own efforts."

(Clarke). 
"Chira migudazl za sauda'e zar?

Chira mikashi bar-1-mihnat chu khar?

Chunan gashta'l sayad bahar shikar

Ki yadat niayad za ruz-i-shumar."

Paidiama of S'adi.

"Why destroy thyself by thy marness after gold?

Wherefore dost thou carry the burden of labour like the ass?

In such manner hast thou become the prey of thy own pursuits,

That thy memory neglecteth the day of account." (GLADWIN).

"Chira za sayad naparrad basue Sultan baz.

Chu bishnawad khabar-i-irj'i za tabl wa duwal?

Chire chu zarra niayad baraqas har sufl

Dar aftab-i-baqa ta rihandash za zawal." Diwas-1-Shams-1-Tabriz.

"Why should a falcon not fly from the quarry towards the King

When it hears by drum and drum.stick the notice of 'Return?'

Why should not every Sufi begin to dance like a mote,

In the sun of eternity that it may deliver him from decay."

"Chub-i-tar-ra chunan ki khwahi, pich,

(Nicholson). Na shawad khushkjuz b'atish rast."

Gulistan, chap. 7.

"Wood, while 'tis green, thou may'st at pleasure bend,

When dry, thou canst not change it, save by fire."

" Chubra ab faru mi na burd, hikmat chist?

(EAstwick).

Sharm dard za faru burdan parwarda'e khwesh."

"Water engulfs not wond and wherefore so?

ANWAR-I-SUhEIt.I.

It swallows not that which itself made grow." (EAstwick).

"Chu aftab bar ayad kuja bamanad shab?

Rasid aish-i-'inayat, kuja bamanad "ana?" Diwan-i-Shams-1.TABriz.

"When the sun goeth up, where stayeth night?

When the joy of bounty came, where lagged affliction?"

"Chu andar nitafe atish zadi,

(NicholsoN).

Za shiran parhez agar bakhiradi."

Bostan of S'ADr, chap. 8.

"When thou settest fire to the cane-brake,

If thou art wise shun the tigers."

(Clarke).

" Chu 'anqabut az duda lu'ab-i-andesha

Digar mabaf ki pusida pud wa tar buwad;

Chu tulnagui, guft-i-tu guft-i-u bashad

Chu tu nabafl, bafanda kirdigar buwad." Drwan-1-SHahis-1-Tabriz.

"Weave no more with soot, like the spider, a web of care,

Wherein both woof and warp are rotten.

While thou art silent, His speech is thy speech,

While thou weavest not, God is the weaver." (Nicholsox). 
" Chu az gulumbe dida bashi khushi Rawa bashad ar bar-i-kharash kashi."

Bostan of S'Adi, chap. 7.

"When thou mayst have experienced pleasure from a rose lush,

If thou endurest the burden of its thorn, it is proper. (CLARKE).

" Chu baz bash ki saiyadi kuni wa luqma dihi, Tufail khwara mashu chun kalagh bi par wa bal."

Axwak-I-SUheILI.

"Be like the hawk, the quarry chase, and food to others give, Not like the raven's callow brood, a remnant-eater live."

(EASTWICK).

"Chu dar rah babini burida sari,

Kl ghaltan rawad sue maidan-i-ma,

Az u purs, az u purs asrar-1-dil,

K'azu bishnawi sirr-i-pinhan-i-ma."

Diwan-i-Shamis-i-Tabriz.

"When thou seest in the pathway a severed head,

Which is rolling toward our field,

Ask of il, ask of it the secrets of the heart,

For of it thou wilt learn our hidden mystery."

(NICHOLSON.)

" Chu ghuta pa zadam wa andaru na didam durr, Gunah bakht man ast, in gunah darya nest."

Firdausi.

"When I dived in the sea without finding pearls, it was the fault of my unhappy star, and not that of the sea."

(OUSELEY).

"Chu insan na danad bajuz khwurad wa khwab, Kudamash fazilat buwad bar dawab?"

Bostan OF S'adi.

"When a man understands only eating and sleeping,

What excellence hath he over the reptiles?" (CLARKE).

" Chu jang awari ba kase dar sitiz

Ki az way guzirat buwad ya guriz."

Gulistan, Preface.

"When thou contendest, choose an enemy

Whom thou mayst vanquish or whom thou canst fly."

(EASTWICK).

“ Chu kardi ba kalukh-andaz paikar

Sar-i-khudra banadani shikasti ;

Chu tir andakhti dar rue dushman,

Hazar kun k'andar amajash nashasti."

Gulistan, chap. r.

"When with a practised slinger thou wouldst fight,

Thou by thy folly thine own head will break, Ere 'gainst thy foe thine arrow wings its flight, See thou beyond his range position take."

(EAstwick). 
"Chu kare be fuzul-i-man bar ayad

Mara dar way sukhan guftan nashayad;

Wa gar binam ki na bina wa chah ast,

Agar khamush binishinam gunah ast."

Gulistan, chap. $x$.

" Without my meddling if a thing succeed

For me to give advice therein, what need?

But if I see a blind man and a pit,

Why then I'm guilty if I silent sit."

(Eastwick).

" Chu khashm ayadat bar gunah kase,

Ta'ammul kunash dar 'aqubat base;

Ki sahal ast 1'al-i-Badakhshan shikast,

Shikasta na shayad digar barah bast."

BOStAN OF S'ADt.

" When anger comes to thee on account of a person's crime,

Reflect much on his punishment,

Because it is easy to break the ruby of Badakhshan,

Broken, it is impossible to fasten it together again."

(Clarke).

"Chu khud-ra qawi bini we khush,

Ba shukrana bar-i-zaifan bikush."

Bostan of S'Adi.

"When thou seest thyseif of strong state and happy

Endure thankfully the burden of the feeble." (ClarkE).

" Chu khud-ra za nikan shumardi, badi,

Na mi ganjad andar khuda'i khudi;

Agar murdi az mard'ai khud ma gui

Na har shahsaware badar burd gui."

BOSTAN OF S'ADI.

"When thou reckonest thyself among the good, thou art already evil; self-righteousness hath no place in godliness.

"If thou art valorous boast not of thy valour; for not every good rider hath borne off the prize."

AsIatic Jouknal.

"Chu kudakan hala ta chand ma ba alam-1-khak

Kunem daman-i-khud pur za khak wa sang wa sifal?

Za khak dast badarem wa bar sama parrem,

Za kudaki bagurezem sue bazam-i-rijal." Diwan-I-Shans-I-TABriz.

" IJow long shall we, like children in the earthly sphere

Fill our lap with dust and stones and sherds?

Let us give up the earth and fly heavenwards,

Let us flee from childhood to the banquet of $\mathrm{mcn}$.

(Nicholsox).

"Chu lashkar birun takht khashm az kamin,

Na insaf manad, na taqwa, na din,

Na didam chunin div zer-i-falak

K'az u migurezad chandin malak."

Bustan of S'adt. 
" Like an army anger rushed from anbush, Justice remained not, nor piety, nor religion ; I saw not such a demon (as anger) beneath the sky From whom so many angels fly." sEEA schwoy T (CIARKE).

"Chu mastur bashad zan-i-khub rue, Bi didar-i-u dar bihisht ast shui."

BosTaN OF S'ADI, chap. 7 .

"When the wife of beautiful face is chaste, The husband by beholding her is in Paradise."

"Chun 'adu nabud jihad amad muhal, (Clarke). Shahwat ar nabud, nabashad imtisal, Sabr nabud, chun nabashad mail-i-tu, Khasam chun nabud, nabashad hajat khail-i-tu."

JALALUDDIN RUMi.

"Were there no hostility, war would be impossible, Hadst thou no lust, obedience to the law could not be Hadst thou no concupiscence there could be no aisstinence Where no antagonist exists, what need is there of armies?"

(WIINFIELD).

"Chunan litafat wa khubi wa husn wa jan-bakhshi, Kase az u bishkibad, zihi shaqa wa dhalal, Bipar, bipar, hala, ey murgh sue m'adan-i-khwish, Ki az qafs birahidi wa baz shud par wa bal. Az ab-i-shor safar kun basue ab-i-hayat, Ruj'u kun ba sue sadar-i-jan za saff-i-n'ial."

(Diwan-I-Shanis-1.TABRIz).

"Such grace and beauty and loveliness and bestowal of life, $\mathrm{O}$ misery and error, if anyone dispense with Him !

Fly, fly $\mathrm{O}$ bird, to thy native home,

For thou hast escaped from the cage, and thy pinions are outspread.

Travel away from the bitter stream towards the water of life,

Return from the vestibule to the high seat of the sonl." Nichor.son.

"Chun asl-i-chashma baqist, far'ash hamesha saqist,

Chun har du bi zawaland, az chi tura fughanast?

Janra chu chashmae dan wa in sun'aha chun jauha, Ta chashma hast baqi, jauha az u rawanast;

Ghamra birun kun az sar, wa in ab-i-jau hama khur, Az faut-i-ab m'andesh $k$ 'in $a b$ be kiran ast."

Diwan-I-Shanis-I-Tabriz.

"Whereas the springhead is undying, its branch gives water continually; Since neither can cease, why are you lamenting?

Conceive the Soul as a fountain and thcse created things as rivers; While the fountain flows, the rivers run from it Put grief out of your head, and keep quaffing this river water, Do not think of the water failing ; for this water is without end." 
"Chu natawan bar aflak dast akhtan,

Zarurist ba girdishash sakhtan;

Garat zindagani nabisht ast wir,

Na marat guzayad na shamshir wa tir." Bostan of S'AD1, chap. 5.

"Since one cannot draw forth the hand against the sky,

It is necessary to be content with its revolution;

If God has written for thee long life

Neither the snake nor the sword nor the arrow may injure thee."

(CLARKE).

"Chun az qauml yake bl danishi kard,

Ni kihra manzalat manad na mihra;

Na mi bini kl gawe dar 'alaf zar

Biyalayad hama gáwan-i-dihra?"

GuListan, chap. 2.

"When hut one member of a tribe has done

A foolish act, all bear alike disgrace;

Seest thou how in the mead one ox alone

Will lead astray the whole herd of a place?"

(EASTWICK).

"Chun az rasti bugzari, kham buwad,

Chi marde buwad k'az zane kam buwad?"

BOSTAN OF S'ADI, chap. 9.

"When thou passest out of straightness, it is crookedness,

What kind of man is he who is less than a woman?"

(Clarke).

"Chun ba didi gardish sang asia,

Ab ju ra ham bibin akhir bia,

Khak-ra didi baramad dar bawa,

Darmiyan khak bingar bad-ra.

Dighae flkr mi bini ba jush,

Andar atish ham nazr mi kun bahush

Guft Haqq Alyub ra 'dar karamat

Man ba har mui tu sabr dadamat'

Hin, ba sabr khud makun chandin nazr,

Sabr didi, sabr dadanra nigar."

JALALUdDin Rumi.

"When you have seen the millstone turning round,

Then, prithee, go and see the stream that turns it.

When you have seen the dust rising up into the air,

Go and mark the air in the midst of the dust.

You see the kettles of thought boiling over,

Look with intelligence at the fire beneath them.

God said to Job " Out of my clemency

I have given a grain of patience to every hair of thine"

Look not then, so much at your own patience, After seeing patience, look to the giver of patience."

(WHINFIELD). 
"Chun ba haqq na bud bidar jan-i-ma, Hast bidari chu dar bandan-i-ma, Jan hama roz az lakd wa kub khiyal, Wa za ziyan sud wa za khauf zawal, Nai safa mimanadash nai lutf wa far, Nai basue asman rah safar.

Khufta an bashad ki u az har khiyal Darad ummid wa kunad ba u maqal."

JaLALUdDin RUMi.

"'Our wakefulness fetters our spirits, Then our souls are a prey to various whims, Thoughts of loss and gain and fears of misery. They retain not purity nor dignity nor lustre, Nor aspiration to soar heavenwards.

That one is really sleeping who hankers after each whim And holds parley with each fancy."

(WHINFIELD).

"Chun banda'e khuda khwish khwanad, Bayad ki bajuz khuda na danad."

Gulistan, chap. 2.

"Who calls himself God's servant must forego All else and none beside his Maker know." (EASTwICK).

"Chun base Iblis adam rue hast, Pasjba har daste na shayad dad dast."

Jalaluddin Rumi.

"As there are many demons with men's faces, It is wrong to join hands with every one."

(WHINFIRLD).

"Chun buwad asl-i-jauhar qabil, Tarbiyatra dar u asr bashad ; Hich saiqal niku nadanad kard Ahanera ki bad gauhar bashad."

Gulistan, chap. 7.

"Is your first nature such that teaching can Affect it, soon instruction will take root : But iron which at first imperfect ran Forth from the furnace, who can then imbue it With the capacity of polish ?"

EASTWICK.

"Chun duyam az awwalaniyat bihtar ast,

Pas fana jui wa mubaddal-ra parast;

Sad hazaran hashr didi, ey 'anud,

Ta kunun har Iahza az badu wujud,

Az jamadi bikhabar sue nama,

Wa za nama sue hayat wa ibtila ;

Baz sue aql wa tamizat khush;

Baz sue kharij in panj wa shash."

JalAluddin RUMi. 
"Since the latter of your states were better than the former,

Seek annihilation and adore change of state ;

You have already seen hundreds of resurrections

Occur every moment from your origin till now;

One from the inorganic state to the vegetive state,

From the vegetive state to the animal state of trial;

Thence again to rationality and good discernment,

Again you will rise from this world of sense and form."

(WHINFJELD).

- Chun faut shawam babada shu'id mara,

Talqin za sharab wa jam guyid mara,

Khwahid baruz-i-hashr yabid mara,

Az khak-1-dar-1-mekdah juyid mara."

Onar Kinayyar.

"When I am dead, with wine my body lave,

For obit chant a bacchanalian stave,

And if you need me at the day of doom,

Beneath the tavern threshold seek my grave."

WHINFJELD.

"Chun galukhe basifat tu ba hawa bar na shawi, Ba hawa bar shawi, ar blshkuni wa gard shawi, Tu agar nashkuni, an k'at bisarisht u shikanad."

DIWAN-1-ShAMS-1-TABRIZ.

"Since you are properly a clod you will not rise into the air ;

You will rise into the air if you break and hecome dust,

If you break not, He who moulded you will break you:"

(Nicholson).

"Chun gul bachaman daman pur zar namud,

Bulbul ba hazar saut dustanash situd;

Wa an gah ki ba bad raft bargiash ki bud;

Kas nam-i-gul az zaban-i-bulbul na shanud."

Anivar-1-Suheill.

"When the rose her skirt of gold showed in the parterre,

With a thousand songs the nightingale her praises did proclaim;

But alas ! her leaves were soon scattered to the air,

And then no more did any hear from the nightingale her name."

"Chun guzidi pir, nazuk dil ma bash,

Sust wa razida chu ab wa gil mabash;

War ba har zakhme tu pur kina shawi,

Pas kuja be saiqal aina shawi?"

Jalaluddin Rum.

" Having chosen thy Director, be not weak of heart

Nor yet sluggish and lax like water and mud;

But if thou takest umbrage at every rub

How wilt thou become a polished mirror?"

WHINFIELD. 
"Chun hasil-i-admi dar in shuristan Juz khurdan-i-ghussa nest ya kandan-i-jan, Khurram dil-i-an ki z'in jahan zud biraft, Asuda kase ki khud nifamad bajahan."

Omar Khayyam.

"Since all we gain in this abode of woe Is sorrow's pangs to feel and grief to know, Happy are they that never come at all, And they, that, having come, the soonest go."

"Chun kar na bar murad-i-ma khwahad raft,

WHINFIELD, Andeshae jihd-i-ma kuja khwahad raft, Paivasta nishasta em az hasrat-i-anak, Dir amada em wa zud mibayad raft."

Omar Khavyam.

"Fate will not bend to humour man's caprice, So vaunt not human powers but hold your peace, Here must we stay, weighed down with grief for this, That we were born so late, so soon decease." (Whinfield).

" Chun kase 'agar' wa 'magar' ra juft sazad, farzande ki az ishan mutwallid shawad 'kash ki' khwahad bud." ANWAR-1-SUHRILI.

"When any one takes 'if' and 'perchance' for his partner, the offspring will be sure to be 'would that I had not."'

"Chun khuda khwahad ki purda kas darad,

Mailash andar t'ana pakan burd,

War khuda khwahad ki poshad alb-i-kas,

Kam zanad dar aib-i-maiyuban nafas."

JaLALUdDIN RUM.

"When God decides to humble any sinner proud

A demon stirs this last to insult some man of God

And he whom God elects to cloak where 'tis he halts

Has grace bestowed on him to cover others' faults."

"Chunki barbukast jumla karha,

(REDHOUSE).

Kar din aula k'az an yabi riha;

Nist dasturi dar in ja qar'a bab

Juz ummid wa Allah 'alim bi 'sawab."

JaLAluddin Rumi.

"Since all things are dependent on probability,

Religion is so first of all, for thereby you find release.

In this world no knocking at the door is possible

Save hope, and God knows what is best." (Whinfield).

"Chunki guyanda na darad jan wa far,

Guft u-ra kai buwad barg wa samr?

Mikunad gustakh mardum ra barah,

U bajan larzantar ast az barg-i-gah ;

Gar hadisash niz ham ba far buwad,

Dar hadisash larza ham muzmir buwad."

JAlalUddin Rumi. 
"W'hen the preacher himself has no light or life,

Ilow can his words yield leaves and fruit?

He impudently preaches to others to walk aright,

While himself he is unsteady as a reed shaken by wind.

Thus though his preaching is very eloquent,

It hides within it unsteadiness in the faith."

(WHINFIELD).

"Chunki nabud ranj sabari mar tu ra,

Shart na budash faru niayad jaza ;

Habbaza an shart wa shada an jaza,

An jaza'e dil-nawaz jan-faza."

JALALUdDIN RUMi.

"When thou endurest not the pains of abstinence,

And fulfillest not the terms, thou gainest no reward;

How easy those terms! how abundant that reward!

A reward that enchants the heart and charms the soul."

(WHINFIRLD).

"Chun kuni ba bihasad makar wa hasad,

Z'an hasd dilra siyahiha rasad;

Khak shu mardan haqq ra zer pa,

Khak bar sar kun hasadra ham chu ma."

Jalaluddin Rumi.

"Should envy fill thy breast 'gainst one that envies not

Foul stains ensue; thy heart's impure ; all good's forgot

Prostrate thyself then at the feet of holy men,

Cast dust upon thy head, God's pardon to obtain."

(REDHOUSE).

"Chun lala ba nauruz qadah gir badast

Bà lalarukhe agar tura fursat hast;

Mai nush bi khurrami ki in charkh-i-kabud

Nagah tura chu bad gardanad past."

Omar Khavyam.

"Like tulips in the spring your cups lift up

And with a tulip-cheeked companion sup

With joy your wine, or e'er this azure wheel

With some unlooked for blast upset your cup."

(WHINFIELD).

"Chun mard dar uftad za jae wa maqam-i-khwish,

Digar chi gham khurad hama afaq ja'e ust?

Shab har tawangare basara'e hamirawad,

Darwish har kuja ki shab amad, sara'e ust." Gulistan, chap. 3.

"Whene'er a man from home and country flies

All earth is his ; he has no further care,

Each night the rich man to his palace hies

Where night descends, the poor man's home is there."

(EAstivick). 
"Chun na dari kamal-i-fazl, an bih

$\mathrm{Ki}$ zaban dar dihan nigahdari ;

Admira zaban fazihat kunad

Juzi be maghzra subuksari,"

Gulistan, chap. 8.

" Hast thou not perfect excellence, 'tis best

To keep thy tongue in silence, for 'tis this

Which shames a man; as lightness does attest

The nut is empty, nor of value is."

EASTIVICK.

"Chun pir shudi, za kudaki dast bidar ;

Bazi wa zarafat ba jawanan bugzar."

Gulistan, chap. 6 .

"When thou art old, thy pastimes put away;

Leave frolics to the young, and mirthful play."

(EASTWICK).

" Chun qaza birun kunad az charkh sar,

Aqilan gardand jumla kor wa kar ;

Mahiyan uftad az darya birun;

Dam girad murgh parranra zabun."

ANWAR-I-SUHEILI.

"When fate's dark features from the mantle rise

Of sight and hearing both they rob the wise;

Fish on the shore from ocean's breast are tossed,

And soaring birds in earth-set snares are lost."

EASTIWICK.

" Chun ranj bar natawani girift az ranjur,

Qadam za raftan wa pursidanash darigh madar,

Hazar sharabat-i-shirin wa mewa'e mashmum

Chunanan mufld na bashad ki bue suhbat-i-yar."

SA'DI.

"Were all thy fond endeavours vain

To chase away the sufferer's smart

Still hover near lest absence pain

His lonely heart.

For friendship's tones have kindlier power

Than odorous fruit or nectared bowl

To sooth in sorrow's languid hour

The sinking soul." (Asiatic Journal).

"Chun rishta kast, mi-tawan bast,

Lek bamiyan girih bamand."

ANWAR-I-SUhEILI.

"The broken cord may yet be joined again

But in the midst a knot will aye remain." EAsTwick.

"Chun sag-i-darinda gusht yaft,

Na pursad k'in shutur Salihast ya khar-i-Dajjal."

Gulistan, chap. 7.

"When a ravenous cur finds meat, small care has he

If Salih's camel or Dajjal's ass it be."

(EASTWICK). 
" Chun shahid-i-ruh khana pardaz shawad, Har jins b'asl-i-khwishtan baz shawad, In saz-1-wujud-i-char abresham tab'a Az zakhma'e ruzgar bisaz shawad."

Omar Khavyam.

"When the fair spirit doth this house vacate, Each element resumes its prinal state And these four strands of life, like threads of silk Are all unravelled by the blows of fate." (Witinfirld).

"Chun sukhan dar wasf in halat rasid, Ham qalam bishkast wa ham kaghaz darid; Aftab amad dalll-1-aftab, Gar dalilat bayad, az wai ru matab." Jalazudin Rusi.

" When the discourse touched on the matter of love, Pen was broken and paper torn; None but the sun can display the sun, If you would see it displayed, turn not away from it."

(WHINFIELD).

"Chun tayammum ba wujud ab dan Ilm naqli ba dam qutb-i-zaman, Khwish abla kun, t'aba mir wa sipas Rastagi za in ablahi yabi wa bas."

Jalaluddin Rumi.

"Traditional knowledge when inspiration is available

Is like making ablutions with sand when water is near Make yourself ignorant, be submissive, and then You will obtain release from your ignorance." (Whinfield).

"Chun tir-i-qaza za shast-i-taqdir bajust, Hargiz na kunad radd sipar-i-tadbirash."

Anwar-i-Suheili,

"When from fate's string its arrow once has hied Expedient's shield can ne'er it turn aside." Easrwick.

"Chun tu bashi bakht-i-khud, ey m'anawi, Pas tu ki bakhti za khud kai kam shawi? Tu za khud kal kam shawi, ey khush khisal, Chunki ain tu tura shud mulk wa mal."

Jalaluddin Rum.

"When, O spiritual one, thou hast become thy own fortune Then, being thyself thy fortune, thou wilt never lose it How, $\mathrm{O}$ fortunate one, cans't thou ever lose thyself When thy real self is thy treasure and thy kingdom."

(WHINFIELD).

"Chun tu natawani ki raz-i-khwishra pinhan kuni, Pas chira ranje gar anra digare afsha kunad?" ANwAR-1-SuheIl.

"When thine own secret thou canst not conceal, Why art thou vexed if others it reveal?" (EAsTwICK). 
" Chun uhda na mishawad kase fardara,

Hail khush kun in dil-i-pur saudara ;

Mai nush binur-i-ma ai mah, ki mah

Bisyar bitanad wa na yabad mara."

Omar Khayyam.

"Since no one can assure thee of the morrow

Rejoice thy heart to-day and banish sorrow

With moon-bright wine, fair moon ! the moon in heaven

Will look for us in vain on many a morrow:" (WhiNfiELD).

"Chun waqifl, ey pisar, za har asrare,

Chandin che khuri ba behuda timari,

Chun minarawad ba ikhtiyare kare,

Khush bash darin nafs ki hasti bare."

Omar Khayyam.

"You know the secret of this life nıy dear

Then why remain a prey to useless fear?

Bend things to suit your whims you cannot; yet

Cheer up for the few moments you are here."

(WHINFIELD).

"Chun zan rah-i-bazar girad, bizan.

Wagarna tu dar khana binshin chu zan." Bostan of S'ADi, chap. 7.

"When the wife takes the path to the bazar, strike,

Otherwise sit in the house, wife-like."

(CLARKE).

"Chu panja salat birun shud za dast,

Ghanimat shumir panj ruze ki hast."

BOSTAN OF S'ADI, chap. 9 .

"When fifty years have gone forth from thy hand

Consider it gain that there is a space of five days."

(Clarke).

"Chu piruz shud duzd-i-tira rawan,

Chi gham darad az giriya'e karawan?"

Gulistan, chap. 2.

"When the dark-minded robber finds success

What cares he for the caravan's distress?" (EASTwICK).

"Chu shah ra na buwad agahi za hal sipah, Kuja sipah za qahr wai ihtiraz kunad?

Biqasd-i-jam hazaran bahana pish arand, Bi chang-i-flsq hazaran tarana saz kunand."

Jani, Biharistan, chap. 3 .

"If the Shah be not aware of his army's state,

How can the soldiers avoid his severity?

They have a thousand excuses for quaffing wine,

They sing a thousand songs; profligacy tuning the lute."

REHATSEK. 
Chu qatra az watan-i-khwish raft wa baz amad, Musadif-i-sadafl gasht wa shud yake gauhar ;

Na Yusife besafar raft az pidr-i-giryan?

Na dar safar ba sa'adat rasid wa mulk wa zafar?"

DIWAN-I-Shams-I-TABRIz.

"When the drop departed from its native home and returned

It found a shell and became a pearl.

Did not Joseph go on a journey from his father weeping

Did he not in the journey come to fortune and kingdom and victory?"

" Chu shahbaz ba jaulan dar ai wa sairi kun,

(NICHOLSON).

Chu chagd chand tawan bud dar pas diwar?"

Anwar-1.SUheili.

"Swoop like falcon forth, to distant regions fly,

Owl-like how long wilt thou behind the ruin lie?"

" Chu sham'a az pai ilm bayad gudakht,

Ki bi "lim natawan khudara shinakht."

EASTWICK.

"To gain knowledge you should consume yourself like a candle

Since without it you cannot know God."

Gradwin.

"Chu shawad ruza maya'e azar,

Ruza khwari za ruza dari bih;

Khue khudra az ruza tiz makun,

K'az hama hilm wa burdbari bih."

JaMi Biharistan, chap. 2.

"If fasting becomes an occasion of trouble

Then the breaking of it is better than the keeping;

Do not make thy humour impatient by fasting

Because meekness and forbearance surpass all things."

" Chu sindan kase sakht rui na kard,

ReHATSEK.

K1 khasik-1-tadib ba sar na khurd,

Ba guftan durushti makun ba amir

Chu binf ki sakhti kunad, sust gir,

Ba akhlaq ba har ki bini bisaz,

Agar zer dast ast wa gar sarfaraz."

Bostan of S'ADI, chap. 4.

"No one made a hard face anvil-like,

Who suffered not the chastising hammer on his head;

Exercise not vehemence in speaking to an amir,

Pursue gentleness, when thou seest that he practises severity ;

Make thyself by manners concordant with whomsoever thou mayest see

Whether he be inferior, or superior."

(ClaRkE).

" Chu taharat na buwad k'aba wa butkhana yakist, Na buwad khair dar an khana ki "Ismat na buwad."

Hafiz.

" Like are, if void of purity, the k'aba and the idle-fane

The house that has not chastity can in its walls no good contain."

BickNelL. 
"Chu tir mi-barawad chu murgh-i-gumanat, Yaqin bidan ki yaqinwar az guman bigurizad, Chunan gurizad namash chu qasd-i-guftan binad, Chunan gurizad az tu ki gar nawisi naqsash, Za lauh naqash biparrad, za dil nishan bigurizad."

DIWAN-I-SHAMIS.I-TABRIZ,

"As the arrow speeds from the bow, like the bird of your imagination Know that the Absolute will certainly flee from the imaginary His name will flee when it sees an attempt at speech; He will flee from you so that if you limn his picture The picture will fly from the tablet, the impression will flee from the soul."

(NICHOLSON).

"Chu zauq-i-sukhtan didi, digar nashkibi az atish, Agar ab-i-hayat ayad tura za atish m'angizad."

Diwan-I-Shams-I-TABRIz.

"Thou wilt never more endure without the flame, when thou hast known the rapture of burning.

"If the water of life should come to thee, it would not stir thee from the flame."

(NICHOLSON).

"Dah darwish dar galime bikhuspand wa du padshah dar iqlime dar naganjand."

GULISTAN, chap. r.

"Ten dervishes may sleep under one blanket, but one country cannot contain two kings."

(EASTWICK).

"Dalqat ba chi kar ayad? wa tasbih wa muraqq'a?

Khudra za 'amalhae nakuhida bari dar.

Hajat ba kulah-i-baraki dashtanat nest ;

Darwish sifat bash wa kulah-i-tartari dar." Gulistan, chap. 2.

"Of what avail is frock or rosary

Or clouted garment? - Keep thyself but free

From evil deed, there is no need for thee

To wear the cap of felt ; a darwesh be

In heart and wear the cap of Tartary." (EASTwICK).

"Daman-aluda agar khud hama hikmat goyad,

Ba sukhan guftan zeba'ash bad an bih na shawad;

Wa an ki pakiza dil ast ar binshinad khamush, Hama az sirat-i-safash nasihat shanawand."

ANWAR-I-SUHEILI.

" One stained with crime, though all he says be wise

Makes no one better by his eloquence

While in the pure of heart such doctrine lies

That though maintaining silence, all men thence

Learn to be good by tacit inference." (EAsTwICK). 
"Daman-1-chun tu, nigari, za kaf asan na diham, KI bakhunaba'e bisyar ba dast amadi."

ANWar-1.SUHeILI.

"From the skirt of one so fair as thou I'll ne'er consent to part, For with many a flood of tears thou hast been purchased by this heart." EAstivick.

"Daman-i-u gir, ey yar-1-diler,

K'u munazza bashad az bala wa zer ;

Ba tu bashad dar makan wa bi guman,

Chun bamani az seral wa az dukan;

U baraurad az kaduratha safa,

Mar Jafaha tura girad wafa."

JALALUdDIN RUMi.

"O brave friend, grasp His skirt,

Who is removed alike from the world above and below;

Who will abide with thee in the house and abroad

When thou lackest house and home

He will bring forth peace out of perturbations

And when thou art afflicted, will keep His promise."

(WHINFIELD).

"Dam az rasti gar zani subhwar,

Za tariki jahl giri kinar."

Pandnasia of S'adr.

"If you breathe truth like the true day-spring,

You will separate yourself from the darkness of ignorance."

Gladwix.

"Dame chand guftam bar aram bakam,

Darigha ki bagirift rah nafs;

Darigha ki bar khwan-i-elwen-i-umr,

Dame chand khwardam wa guftand 'bas.'” Gulistan, chap. 6.

" Methough a few short moments I would spend

As my soul wished; alas! I gasp for air

At the rich board where all life's dainties blend

I sate me down-partook a moment there

When ah! they bade me leave the scarcely-tasted fare."

(EASTWICK).

"Dam sakht ast magar yar shawad lutf-i-khuda,

Warna Adam na barad sarfa zi Shaitan-i-rajim." HAFiz OdE 417.

"The meshes of the net are strong but God withholds His grace from none, Not otherwise could man prevail o'er Satan the stone-pelted one."

BICKNELL.

"Dana'e dil kashta zer-i-chunin ab wa gile

Ta babaharat narasad, u shajare mi na shawad."

DIWAN-I-ShaMS-I-TABRIZ.

"The seed of the spirit sown beneath this water and clay (the body) Becomes not a tree until it reach Thy spring." (NICHOLSON). 
"Darakht agar mutaharrik shudi za jae ba jae, Na jaur arra kashidi wa na jafa'e tabr."

Anivar-I-SUheILI.

"From place to place had trees the power to move Nor saw nor axe would wrong the stately grove."

Eastwick.

" Darakhte, ki aknun giriftast pa'e,

Ba nirui shakhse bar ayad za jae,

Wagar hamchunan ruzgari hili,

Ba gardunash az bikh nagsili;

Sar-i-chashma shayad giriftan ba bil,

Chu pur shud nashayad guzashtan ba pil."

Gulistan, chap. I.

"A single arm may now up tear

A tree if lately planted there;

But if it for a time you leave,

No engine could its roots upheave.

A spade may the young rill restrain,

Whose channel swollen by storms and rain

The elephant attempts in vain."

(EASTWICK).

"Darakhte ki paiwasta barash khuri,

Tahammul kun angah ki kharash khuri." Bostan of S'ADl, chap. 7.

"The tree whose fruit thon constantly enjoyest,

At the time when thou sufferest its thorn, be patient."

(CLARKE).

" Dar-azl az kham-i-ishqash qadahe dar dadand,

Za an falak charakh zanan gasht, zamin mast uftad."

AkhLaq-1.Jalalt.

" In remote eternity they presented one cup from the pitcher of His love, Through it the heavens were made to reel and the earth fell intoxicated."

(Asiatic JoURNaL).

"Dar bar abar chu gusfand-i-salim,

Dar qafa hamchu gurg-i-mardum dar."

GuListan, chap. 2.

"Before thee like the lamb they gentle are ;

Absent, than savage wolves more ruthless far."

(EASTwick).

"Darbasta ba rue-khud za mardum,

Ta alb na gushtarand mara ;

Darbasta chi sud? 'alimu 'lghaib

Danai nihan wa ashkara."

Gulistan, chap. 2.

"I close the door before me against men,

That my faults may not stand to them confessed;

Of what avail its bar'gainst Thee whose ken

Sees both the hidden and the manifest?"

(EASTWICK) 
"Dar darun har yake sad khuk ast; Khuk bayad kusht ya zinnar bast."

ATTAR。

"In the heart of each are found a hundred swine

You must slay the hog or bind on the "Zanar." *

" Dar dida-i-tang-i-mur nurast az tu,

Dar pa-i-zaif-i-pasha zurast az tu,

Zat-i-tu sazast mar khudawande ra,

Har wasf ki nasazast durast az tu."

OMAR KhaYyam.

"O Thou who givest sight to emmet's eyes -And strength to feeble limbs of puny fies To Thee we will ascribe omnipotence

No meaner attribute to Thee applies." (Whisirield).

" Dar guzar az nam wa bingar dar sifat,

Ta sifatat rah numayad sue zat;

Ikhtilaf-i-khalq az nam uftad,

Chun ba m'ana raft, aram uftad."

JALALUDDIN RuMi.

" Pass over names and look to qualities

So that qualities may lead thee to essence;

The differences of sects arise from His names

When they pierce to His essence, they find His peace."

"Dar hadis amad ki dil hamchu par ast

(WHINFIELD).

Dar bayabane asir sarsar ast;

Bad par ra har taraf ranad guzaf,

Gah chup wa gah rast ba sad ikhtilaf."

Jalaludin Ruis.

"There is a tradition 'The heart is like a feather

In the desert, which is borne captive by the winds;

The wind drives it everywhere at random,

Now to right and now to left in opposite directions." "

" Dar-i-mir wa wazir wa sultanra

(WHINFIELD).

Bi wasilat magard piraman,

Sag wa darban chu yaftand gharib,

In gariban girift wa an daman."

Gulista.n, chap. I.

"To door of king or minister or peer

Draw thou not nigh, unless with patrons girt ;

For if a poor man at the gate appear,

Warders his collar seize, and dogs his skirt."

" Dar parda-e-asrar kasera rah nist,

(EASTWICK).

Z'in t'abia jan-i-hich kas agah nist,

Juz dar dil-1-khak-i-tira manzilgah nist ;

Afsos ki in fasanha kotah nist."

OMar Khayyam.

* The girdle worn by non-Moslems. 
"All mortal ken is bounded by the veil, To see beyond man's vision is too frail ; Yea! earth's dark bosom is his only home ; Alas! 'twere long to tell the doleful tale."

(WHINFIELD).

"Dar rah-i-niyaz har dili ra daryab,

Dar kui huzur muqbali ra daryab;

Sad ka'ba-e-ab wa gil ba yak dil narasad;

Ka'ba chi rawi? birau dili ra daryab."

Omar Khayyam.

"When seeking love, pay court to every heart,

When once admitted, seek the perfect heart

A hundred ka'bas equal not one heart;

Seek not the ka'ba, rather seek the heart."

(WHINFIELD).

"Dar sukhan ba dustan ahista bash,

Ta nadanad dushman-i-khunkhwar gush ;

Pish-i-diwar anche gui hush dar,

Ta na bashad dar pish-i-diwar gush."

Gulistan, chap. 8.

" In talk with friends speak soft and low'

Lest thy bloodthirsty foeman thee should hear :

A wall may front thee-true! but dost thou know

If there be not behind a listening ear?"

(EASTWICK).

"Darwishe dar munajat miguft "Ya Rabba, ba badan rahmat kun, ki bar nikan khud rahmat karda'j ki ishanra nik afrida'i."

Gulistan, chap. 8.

"A darwesh said in his prayers, "O God! have mercy on the wicked, for Thou hast already had mercy on the good, in that Thou hast created them good." "

EASTWICK.

"Darya flrawan nashawad tira basang;

Arif ki biranjad tang ab ast hanuz."

Gulistan, chap. 2.

"A stone makes not great rivers turbid grow

When saints are vexed, their shallowness they show."

(EASTWICK).

" Daryab ki az ruh juda khwahi raft,

Dar parda'e asrar-i-khuda khwahi raft,

Mai khur ki na dani az kuia amada'i,

Khush bash, na dani ki kuja khwahi raft."

Omar Khayyam

"Make haste! soon must you quit this life below, And pass the veil, and Allah's secrets know;

Make haste to take your pleasure while you may You know not whence you come nor whither go."

WHINFIELD. 


\section{"Daryab kunun ki n'imatat hast ba dast}

K'in daulat wa mulk mirawad dast ba dast." Gílstas, chap. x.

"Now that thy hands retain these blessings, know

This wealth, these lands from hand to hand must go."

" Dast az mis-i-wujud chu mardan-i-rah bishawi,

Ta kimiya'e ishq biyabi wa zar shawl."

(EASTWICK).

"Wash from the dross of life thy hands as the path'smen of old

And winning love's alchemic power, transmute thyself to gold."

" Dast-i-qadrash kbakat sarisht

(BICKNELL):

Harf-i-hikmat dar dil pakat sarisht;

Pak kun az naqsh surat sinara,

Rue dar ma'na kun an aina ra,

Ta shawad ganj-1-mana sina'at

Gharq nur-i-marifat aina'at."

Jami, Salaman and Absal.

"The mighty hand that mixed thy dust inscribed

The character of wisdom on thy heart ;

Oh ! cleanse thy bosom of material form,

And turn the mirror of the soul to spirit,

Until it be with spirit all possessed,

Drowned in the light of intellectual truth."

(Fitzgerald).

" Dast-i-sultan digar kuja binad,

Chun bar sargin dar uftad turunj;

Tishnara dil nakhwahad an kuza,

Ki rasid ast ba dihan-i-sukunj."

Gulistan, chap. $x$.

" Ne'er will the orange from the sultan's hand

Once in the dung-hill fallen, more there rest :

Though thirsty, none will water e'er demand,

When ulcerated lips the jar have pressed." (EAsTwick).

" Daud guft 'Ey padshah chun bi niyazi tu za ma,

Hikmat chi bud akhir bigu dar khilqat-i-har du sara?'

Haqq guftash 'Ey mard-i-zaman ganje budam man dar nihan;

Justam ki ta paida shawad an ganj-i-ihsan wa'ata." "

DIWAN-1-SHAMS-1-TABRI7.

" David said ' $O$ Lord, since Thou hast no need of us,

Say then, what wisdom was there in creating the two worlus?'

lod said to him 'O temporal man, I was a hidden treasure;

I sought that that treasure of loving kindness and bounty should be revealed.' "

(Nicholson).

"Daulat dunya ki tamanna kunad?

Ba kih wafa kard ki ba ma kunad?"

ANWAR-I-SUHEILJ.

"Who would wish for this world's riches, a vain and fleeting shew?

To whom have they proved faithful, that to me they should be so?"

EASTw1Ck. 
“Daur-i-jawani bashud az dast-i-man

Ah I darigha an zaman dil-faruz;

Quwat-i-sar panja-e-sher biraft,

Raziam aknun ba panire chu yuz."

Gulistan, chap. 6.

"Youth's circling hours have passed for aye away,

Ah me ! alas, that that gay time is spent;

The lion feels his strength of paw decay,

Now, like a pard, with cheese-scraps I'm content."

EAstwick.

'Dawam parwaris h andar kinar madar dahr ;

Tama "makun ki dar u bui mihrbani nest."

ANwar-I-Suheili.

" Hope not from mother fortune for a constancy

That she will nurse thee gently on her lap;

There the true scent of kindness does not lie."

Eastwick.

"Dhalika bi'anna 'llaha lam yaku mughayyiran ni'amatan 'an'amaha 'ala qaumin hatta yughayyiru ma bi'anfusihim."

Koran, chap. 8.

"This, because God changeth not the favour with which $\mathrm{He}$ favoureth a people, so long as they change not what is in their hearts."

(RODWELL).

“Dhalika' lkitabu la raiba fihi hudan lilmuttaqin." Korav, chap. 2.

"No doubt is there about this Book: It is a guidance to the Godfearing."

(RODWELL).

"Dhama'un biqalbi la yakadu yusighuhu

Rashfu 'zzulali wa lau sharibtu buhura."

Gulistan, Book V.

The thirst of my heart cannot be slaked with a drop of water, nor if I should drink rivers, would it be lessened." (EAsTwick).

"Dhaqat 'alaihimu 'l'ardhu bima rahubat wa dhaqat 'alaihim 'anfusuhum wa dhannu 'an la malja mina 'llahi 'illa 'ilaihi thumma taba 'alaihim liyatubu 'inna 'llaha huwa 'ttawwabu 'rrahim."

KorAN, chap. 9 .

"The earth, spacious as it is became too strait for them; and their souls became so straightened within them that they bethought them that there was no refuge from God but unto Himself. Then was He turned to them that they might be turned to Him, for God is He that turneth, the Merciful."

(KONWELL).

"Dharni wa man khalaqtu wahidā."

KorAs, chap. 74 .

Leave me alone to deal with him whoin I have created."

(RODWELL). 
"Dhuriba mathalun fa' stami'u lahu, inna 'lladhina tad'una min duni 'llahl lan yakhiuqu dhubaban wa lau l'jtama'u lahu wa'in yaslubhumu 'dhdhubabu shal'an la yastanqidhuhu minhu dha'ufa 'ttallbu wa'lmatlub."

KORAN, chap. 22.

"A parable is set forth to you, wherefore hearken to it. Verily they on whom ye call beside (iod, cannot create a fly, though they assemble for it ; and if the fly carry off aught from them they cannot take it away from it. Weak the suppliant and the supplicated."

(RODWELL).

"Dida'e arzu juz ba suzan-i-fana wa rishta'e ajàl dukhta na gardad."

ANWAR-1-SUHEILI.

"The eye of lust is not stitched but with the needle of annihilation and the thread of dcath."

EASTWICK.

" Didai bayad ki bashad shah-shinas,

Ta shinasad badshahe dar har libas."

JalALundin RUM.

"One must have king.recognising eyes

To recognise the king in each disguise."

" Didar mi-numai wa parhez kuni

Bazar-i-khwish wa atish-i-ma tiz mikuni." Gulistan, chap. 2.

"Thou dost Thy face now show and now conceal;

Thy worth enhancest, and inflam'st our zeal."

(EASTWICK).

" Digaran gardand zard az bim-i-an,

Tu chu gul khandan gah sud wa ziyan;

Z'anki gul gar barg barkash mikunl

Khanda nagzarad, nagardad mansani,

Goyad az khari chara uftam ba gham

Khanda ra man khud za khar aurda am;

Ma' uttasawaf, qal wijdan ulfarh

Fi 'lfawad ind atiyan uttarh."

JaLALUdDin RUm.

"Let others grow pale from fear of misfortune,

Do thou smile like the rose at loss and gain.

For the rose, though its petals be torn asunder

Still smiles on, and it is never cast down.

It says "Why should I fall into grief in disgrace?

I gather beauty even from the thorn of disgrace.'

What is Sufism ? 'Tis to find joy in the heart

Whensoever distress and care assail it."

(WHINFIELD).

" Dihkan-1-sal-khurde chi khush guft ba pisar

K'ey nur-1-chashm-i-man bi-juz az kishti na'd'ravi."

Haf12.

"How well said the aged farmer to his son,

O light of my eyes, thou wilt not reap save that which thou hast sown."

(E. G. BROWNE). 
" Di kuzagare badidam andar bazar

Bar taza gili lakad hami zad bisyar;

Wa an gil ba zaban-i-hal ba wai miguft

Man hamchu tu buda am niku dar."

OMar Khayyam.

"I saw a busy potter by the way

Kneading with might and main a lump of clay;

And lo! the clay cried 'Use me tenderly,

I was a man myself but yesterday."

(Whinfield).

"Dila che basta'e in khakdan-i-bar guzrani ?

Az in khazira birun par ki murgh-i-alam jani ;

Tu yar-i-khilwat-i-nazi, muqim-i-parda'e razi,

Qarargah chi sazi dar in nishiman-i-fani."

Diwan-I-Shams-I-Tabriz.

"O heart, why art thou a captive in the earth that is passing away?

Fly forth from this enclosure, since thou art a bird of the spiritual world; Thou art a darling bosom-friend, thou art always behind the secret veil ; Why dost thou make thy dwelling-place in this perishable abode?"

(NICHOLSON).

"Dilam khana'e mihr yar ast wa bas,

Az an na mi ganjad dar u kin-i-kas."

Bostan of $\mathrm{S}^{\prime} \mathrm{ADI}$, chap. 4 .

"My heart is the house of the love of my friend only, For that reason malice to no-one is contained in it."

(ClaRke).

"Dil andar Samad bayad ey dust bast, Ki ajiztar and az sanam har ki hast."

Bostan OF S'ADI.

"O my friend, thou must fix thy heart on the Eternal; for more im. potent than an idol is all beside."

ASIATIC JourNal.

"Dii ast, ai khiradmand, zindan-i-raz, Chu gufti, niayad bar zanjir baz."

Bostan of S'ADI, chap. I.

" $O$ wise man! the prison of the secret is the heart

When thou didst speak, it came not back to chains."

(Clarke).

"Dil-i-tukhm karan buwad ranj kash,

Chu khirman bar ayad bikhuspand khush."

Bostan of S'ADI, chap. 3 .

"The heart of seed-sowers may be afflicted

But when the harvest is accomplished they sleep pleasantly."

(Clarke).

" Dii sirr-i-hayat agar kamahi danist,

Dar maut ham asrar ilahi danist,

Aknun ki tu ba khudi nadanisti hich, Farda ki za khud rawi, chi khwahi danist."

OMar Khayyam. 
"If the heart knew life's secrets here below, At death 'twould know God's secret's too, I trow ; But if you know naught here, while still yourself, To-morrow, stripped of self, what can you know?"

- Dil tu ra dar kui ahl-1-dil kashid,

(WHINFIELD).

Tan tu ra dar habs ab wa gil kashid;

Hin, ghiza ey dil bidih az hamdile,

Rau, bi jau iqbaira az muqbale."

JALALUdDin RUMi.

"The spirit ever leads to haunts of holy men,

The flesh would cast thee in the pit of sin again.

Beware! Feed thou thy sciul with love from holy ground;

Make haste! seek means of grace from one who grace hath found."

(REDHOCSE).

"Din ba dunya farushan kharand; Yusuf bifarushand ta chi kharand?"

Gulistan, chap. 8.

"Those who barter religion for the world are asses; they sell Joseph and get what in return?"

(EASTWICK).

"Din waraz wa marifat ki sukhandan-1-shiya" gui

Bar dar silah darad wa kas dar hisar nest."

Gulistan, chap. 7.

"Keep thyself true to faith and virtue and be not afraid Of empty posts with arms above the door displayed."

" Di sheikh ba chiragh hami gasht gird-i-shahr

(EASTWICK).

K'az div wa dad malulam wa insanam arzu'st."

DIWAN-I-SHAMIS-1.TABRIZ.

"Yesterday the Master with a lantern was roaming about the city, Crying "I am tired of devil and beast, I desire a man." "

NichOLSON.

" Div chu birun rawad, flrishta dar ayad."

ANWAR-1-SUHEILI.

"When fiends retire, good angels come instead."

" Du baltam jigar kard ruze kabab

EASTWICK.

Ki miguft guyanda'e barabab.

' Darigha! ki bu ma base ruzgar

Birolad gul, wa bishgafad nau bahar;

Base tir wa dal mah wa urdubihisht

Bar ayad ki ma khak bashem wa khisht." BosTAN OF S'ADi, chap. 9.

"One day two couplets made my liver as it were roast meat

When the minstrel with the stringed instrument kept saying,

'Alas! without us, many a time

The rose will grow, and the fresh spring blossom!

Many a fourth, tenth and second month

Will appear, when we are dust and brick."

Clarke. 
" Du bamdad"gar ayad kase bakhidmat-i-shah, Siwum har aina dar wai kunad balutf nigah; Ummid hast parastandagan-i-mukhlisra Ki na-ummid na gardand za astan-1-'llah."

Gulistan, chap. 1 .

"If two mornings one attends the king Doubtless the third a favouring glance will bring ; So in God's court : who worship truly there Hope to be not excluded in despair."

(EAstwick).

" Du chiz hasil umr ast khair wa nam niku, Chu dar in du dar guzri 'kullu man aleiha fan' Ma bash dar pa'e azar wa kam-i-khalq barar, K'az in du kar biyabi sa'adat-i-du jahan."

"Two things life offers,-fame, the virtuous deed

Save these 'all things are subject to decay'

Injure not others, help men to succeed, Thus shalt thou reap a blessing for to-day, And the next world when this has passed away."

EASTWICK.

"Duhul bazir-i-galim ey pisar, na shayad zad, Alam bazan chu dileran miyana'e sahra." Diwan-I-Shams-1-TABriz.

"It behoves not, son, to beat a drum under a quilt, Plant like brave men, thy banner in the midst of the desert."

(Nicholson).

"Duhul dar fighan ast daim, wale

Chi hasil, chu andar mujan hich nest, Garat danishi hast m'ane talab, Basurat mashu gharra k'an hich nest."

ANWAR-I-SUhelli.

" Loudly ever sounds the tabor

But in vain, - within is naught;

Art thou wise, for substance labour,

Semblance will avail thee nought."

EAstwick.

" Dukhtaran ra hama jangast wa jadal ba madar Pisaran ra hama badkhwah-i-pidr mi binam; Ablahan ra hama sharbat zi gulabast wa shakar, Qut-i-dana hama az khun-i-jigar mi-binam. Asp-i-tazi shuda majruh ba zir-i-palan Tauq-i-zarrin hama dar gardan-i-khar mi-binam." HAFiz Ode, 442.

" Daughters of turbulent mind awaking their mothers' ire, And sons who of froward mood wish ill to their sire, I see ; Sherbets of sugar and rose the world to the fool supplies, But naught save his own heart's blood the food of the wise I see ; Galled by the pack-saddle's weight the Arab's proud steed grows old, Yet always the ass's neck encircied with gold I see." 
- Dunan chu galim-i-khwish birun bardand

Guyand "che gham gar hama alam murdand?'" GULISTAN, chap. 7.

"The base who've saved their own vile wrappers, cry,

"What matter though the universe should die?"

(EASTWICK).

' Dunya bamurad randa gir, akhir chi, Wa in nama-e-umr khanda gir, akhir chi, Giram ki bakam-i-dil bamani sad sal, Sad sal digar bamanda gir, akhir chi."

Omar Khayyam.

"Suppose the world goes well with you, what then?

When life's last page is read and turned, what then ?

Suppose you live a hundred years of bliss

Yea, and a hundred more to boot, what then?

(WHINFIELD).

" Dunya didi wa har che didi hich ast,

Wa an niz ki gufti wa shunjai hich ast,

Sar ta sar-i-afaq dawidi hich ast,

Wa an niz dar khana khuzidi hich ast."

Omar Khayyam.

"You see the world but all you see is naught, And all you say and all you hear is naught, Naught the four quarters of the mighty earth, The secrets treasured in your chamber naught."

(WHINFIELD).

"Dunya ki hulmi na'im ast,

Khufta pindarad ki in khud qa'im ast ;

Ta bar ayad nagahan subh-i-ajal,

Wa rihad az zulmat-i-zann wa daghl."

JAI.ALUDDIN RUMI.

"This world which is only a dream

Seems to the sleeper as a thing enduring for ever

But when the morn of the last day shall dawn,

The sleeper will escape from the cloud of illusion."

(WHINFIELD).

"Dushman ba ghalat guft ki man failsuflam,

Izid danad ki anchi u guft niam;

Lekin chu darin gham ashyan amada am

Akhir kam az an ki man na danam ki am."

Omar Khayyam.

"My critics call me a philosopher

But Allah knows full well they greatly err,

I know not even what I am, much less

What is the reason that I sojourn here."

(WHINFIRLD). 
" Dushman chu bini natawan, laf az burut-i-khud mazan, Maghz'ist dar har ustukhwan, mardist dar har pairahan"

Gulistan, chap. 8.

"Twist not thy moustaches boastful, nor with pride thy weak foe scan Every bone contains some marrow, every garment cloaks a man."

EASTWICK.

"Dushman dana ki gham-i-jan buwad .

Bihtar az an dust ki nadan buwad."

A viwar-1-Suheili.

"Foes that embitter life are better far

Than they who ignorant but friendly are."

" Dush murghe basubh mi-nalid

EASTWICK.

'Aql wa sabaram buburd wa taqat wa hush;

Yake az dustan-i-mukhlisra

Magar awaz-i-man rasid ba gush, Guft 'Bawar nadashtam ki tura.

Bang-i-murghi chunin kunad madhush'

Guftam 'In shart admiyyat nest,

Murgh tasbih khwan wa man khamush.'"

Gulistan, chap. 2.

" But yester morn a bird with tender strain,

My reason, patience, sense, endurance stole ;

A comrade, one most near in friendship's claim,

(Perhaps he heard the outpouring of my soul),

Said, 'My belief would ne'er have credited

That a bird's voice could make thee thus distraught,'

'It fits not well my state as man' I said,

'That birds their God should praise and I say naught." "

(EASTWICK).

"Dushman chi kunad chun mihrban bashad dost?"

Gulistan, chap. 1.

"While friends are true, what can the foe effect?"

(EAsTwick).

" Dushman-i-ruz and in qalabgan,

Ashiq-i-ruz and in zarha'e kan,

Z'anki ruz ast aina ta'rif-i-u,

Ta babinad ashrafl ta'rif-i-u.

Haqq qiyamatra laqab z'an ruz kard

Roz binumayad jamal-i-surkh wa zard."

JALALUdDiN RUm.

" Makers of base coin hate the daylight

Coins of pure gold love the daylight,

Because daylight is the mirror that reflects them

So that they see their own perfect beauty.

God has named the resurrection 'that day,'

Day shows off the beauty of red and yellow."

WHINFIELD. 
" Dustanra kuja kuni mahrum,

Tu ki ba dushmanan nazar darf."

Gulistan, Preface.

"When will Thy mercies crown thy friends no more

Thou, who with love regardest e'en Thy foe." (EAstwick)

" Dusti bayad az an guna just,

K'an abadu 'ddhar bemanad durust ;

Khana k'asasash buwad az khisht-i-kham

Past shawad az du sih baran tamam."

ANWAR:1-SuhriL.,

"Seek such a friendship for thyself to gain

As may through endless years endure;

Houses of unbaked bricks a few days rain

Will level with the earth, be sure."

EASTWICK.

" Dusti ra hazar shakhs kam ast

Dushmani ra yake buwad bisyar."

ANwar-i-Suheili.

"A thousand e'en too few for friendship are But one for enmity too much by far."

Eastivick.

" Dust mashumar an ki dar n"imat zanad

Laf-i-yari wa biradar khwandagi,

Dust an bashad ki girad dast-i-dust

Dar pareshan hall wa dar mandagi."

Gulistan, chap. $x$.

" Think not thy friend one who in fortune's hour

Boasts of his friendship and fraternity ;

Him I call friend who sums up all his power

To aid thee in distress and misery."

(EASTWICK).

"Dust nazdiktar az man bamanast, mushkil in ast, man az wai duram,

Chi kunam? ba kih tawan guft? ki u dar kinar-1-man wa man mahjuram."

Gulistan, chap. 2.

" Not to myself am I so near as $\mathrm{He}$

My Friend ; and stranger still, from Him I'm far.

What can I do? Where tell this mystery?

He's in our arms, yet we excluded are."

(EASTIVICK).

"Du sukhan bishnau ar hami-khwahi

Kl shawi az hayat barkhurdar,

Pae dar daman-i-qina'at kash,

Tama' az mal marduman bardar."

ANWAR-I-SUHEILI.

" List to this short advice if thou wouldst fain

From life its vintage of delights obtain

'O'er thine own feet contentment's border fold,

And thy desire from others' wealth withhold."

Eastwick. 
" Du yar-i-zirak wa az bada'e kuhun du mane 'Faraghate wa kitabe wa gusha'e chamane, Man in makam badunya wa akhirat nadiham, Agarchi dar payam uftad har dam anjumane."

HAFIZ ODE, 524 .

"Two sprightly friends two mans " moreover of wine that has long been stored

A leasure hour, a page to muse on, a nook on the verdant sward Not for this earth nor future glory, I'd part with this place of joy

Nor if a crowd, at every moment, my track pursued to annoy."

(BICKNELL).

" El 'abdu yudabbir wa 'llahu yukaddir."

Arabic Proverb.

"The servant arranges, but God settles."

“E1 kardhu mikradhu'l muwaddat."

Arabic Proverb,

"Borrowing is the scissors of friendship."

(E. G. Browne).

"Es-safar sakar."

"Travel is travail."

(BURton).

" Ey anki ba mulk yafti dast rasi,

Daulat talbi, kam talab azar-1-kase;

Sad tigh-i-siyasat an kharabi na kunad

K'azurda makhfl bararad nafse."

(ANivar-I-SuheILI).

"Oh thou to whom an empire's sway is given

Would'st thou be blest, eschew then tyranny;

Not by a hundred swords are realms so riven

As by, if just, one injured victim's sigh." EASTwick.

"Ey anki tu'i khulasa'e kaim wa makan,

Bigzar dame waswasa'e sud wa ziyan,

Yak jam-i-mal az saqi-i-baqi bistan,

Ta baz rihi az gham-i-in har du jahan."

Omar Khayyam.

"O man who art creation's summary,

Getting and spending weigh too much with thee,

Arise and quaff the Etern Cupbearer's wine

And so from cares about both worlds be free."

(WHINFIELD).

* A Persian measure. 
Ey ashiqan, ey ashiqan, hangam-i-kuch ast az jahan!

Dar gush-i-janam mi-rasad tabl-i-rahil az asman,

Nak sarban barkhasta, qitarha arasta,

Az ma halali khasta ; chi khufta ed al karawan?

In bangaha az pish wa pas bang rahilast wa jaras,

Har lahza nafs wa nafas sar mi kunad dar la-makan."

Diwan of Shams-i-Tabriz.

"O lovers, O lovers, it is time to abandon the world,

The drum of departure reaches my spiritual ear from heaven

Behold, the driver has risen and made ready the files of camels

And begged us to acquit him of blame; why, $O$ travellers are you asleep?

These sounds before and behind are the din of departure and of the camel-bells ;

With each moment a soul and a spirit is setting off into the void."

"Ey bad-i-saba, agar tawani,

(NICHOLSON).

Az rah-i-wafa wa mihrbani,

Az man bibari khabar bayaram

K'an sukhta'e tu dar nihani,

Mi murd wa za ishtiyaq mi guft

K'ey bi tu haram zindagani."

HAFIZ

"Breeze which at the morning blowest,

Fly, if faith and truth thou knowest,

Say, to my Beloved one turning ;

He who with thy love is burning

Dying sighs where he is hidden

"Life without thee is forbidden."

(BICKNELL).

" Ey bartar az khiyal wa qiyas wa guman wa wahm,

Wa za har chi gufta and shunidem wa khanda em, Majlis tamam gasht wa ba payan rasid 'umri, Ma hamchunan dar awwali wasf-i-tu manda em."

Gulistan, Preface.

"O Loftier than all thought, conception, fancy or surmise

All vainly Thou art sought, too high for feeble man's emprise Past is our festal day, and reached at length life's latest span, Thy dues are yet to pay, the firstlings of Thy praise by man."

" Ey basi sarha'e pak rikhta dar zir-i-khak

(EASTWICK).

Ta tu bidani ki sar z'an sar-i-digar bapa'st.

An sar-i-asli nihan, wa'in sar-i-far'ai aiyan ;

Z'anki pas az in jahan, "alim-i-bi-muntahast."

Diwan-I-Shams-1-TABRIz.

"O the many pure heads scattered beneath the clay,

That thou mayest know the head depends on that other head ;

That original head hidden, and this derived head manifest,

Forasmuch as behind this world lies the infinite universe."

NichOLSON. 


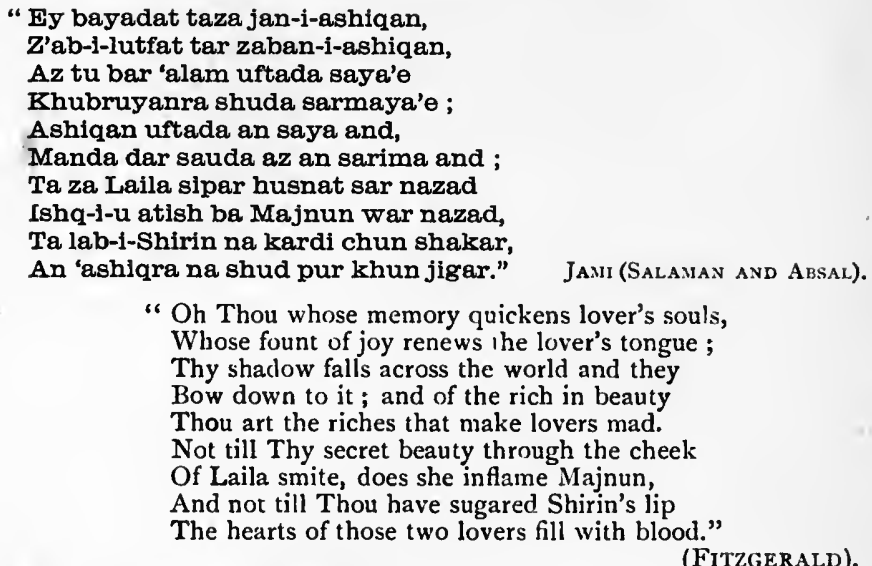

" Ey bi tu haram zindagani!

(Fitzgerald).

Khud bi tu kudam zindagani?

Har zindagi ki bi tu bashad, Margist ba nam zindagani."

Anwar-I-Suheill.

"Life without thee we may unlawful call,

Or reft of thee is it then life at all?

All life without thee is alas the same,

Death, living death and life alone in name." EAstwick.

" Fy biradar tu hamin andisha'i,

Ma baga tu ustukhwan wa risha'i,

Gar gul ast andisha, tu gulshani,

"War buwad khari, tu hima'e gulkhan'i."

JaLALUDDin RUMI,

"O Brother, you are essentially thought,

All the rest of you is bone and sinew,

If your thoughts are rose-like, you are a rose-garden

If they are thorn-like, you are fuel for the furnace."

" Ey bisa kare ki auwal s'ab gasht,

B'ad az bikushada shud, sakhti guzasht;

B'ad naummedi base ummidha'st,

Az pas zulmat base khurshedha'st."

JaLALUDDIN RUMI.

"Ah! many are the conditions which at first are hard, But are afterwards relieved and lose their harshness Oftentimes hope succeeds to hopelessness Many times does sunlight succeed to darkness."

WHINFIELD. 
" Ey bisa zulme ki bini dar kasan,

Khue tu bashad dar eshan, ey fulan,

Andar eshan tafte hasti-i-tu

Az nifaq wa zulm wa bad masti-i-tu,

An tu'i wa an zakhm bar khud mi-zani

Bar khud an dam tar-1-1'anat mi-tant.

Muminan aina'e ek digar and,

In khabar az paigambar awarand;

Pish-i-chashmat dashti shisha kabud,

Z'an sabab 'alam kabudat mi-namud."

Jalaludin Rumi.

"Thou who dost blame injustice in mankind

'Tis but the image of thine own dark mind ;

In them reflected all thy nature is

With all its angles and obliquities;

Around thyself thyself the noose hast thrown

And dost a self-inflicted wound bemoan;

'Back to each other we reflections throw'

So spoke the holy Prophet long ago :

And he who gazes through a glass that's dim

What wonder if the world look dark to him ?"

" Ey dil, ar sail-1-fana bunyad-1-hasti bar kanad,

Chun tura Nuhast kishtiban zi tufan, gham makhur,

Garchi manzil bas khatarnak ast wa maqsad napadid,

Hich rahi nest kanra nest payan, gham makhur,

Hal-i-ma dar furqat-i-janan wa ibram-i-raqib

Jumla mi-danad khuda'e hal gardan, gham makhur."

HAFI7 ODE, 284.

" Heart, should the flood of death life's fabric sweep away;

Noah shall steer the ark o'er billows dark, despair not.

Though perilous the stage, though out of sight the goal,

Whithersoe'er we wend, there is an end, despair not.

If love evades our grasp, and rivals press their suit,

God, Lord of every change, surveys the range, despair not."

" Ey dil az kui'ash bi bur sarmaya'e wird wa niyazi

(BICKNELL).

K'in mita' kasid an ja ruz-i-bazari niyaft."

ANwar-1-Suheill.

"Take from her street, thy stock of grief, thy wailings, $O$ my heart

These unsought goods will ne'er find there a sale-time or a mart."

" Ey dust! bar janaze-i-dushman chu bugzari

EAstivick.

Shadi ma kun, ki bar tu hamin majara buvad."

(ANON).

" $O$ Friend ! when thou passest by the corpse of thine enemy Rejoice not, for on thee will the same fate fall."

"Ey hamnafsan mara za mai quwat kunid

E. G. Browne.

Wa in rue chu kahruba chu yaqut kunid,

Chun murda shawam ba mai bishuyid mara

Wa za chub-i-razm takhta-e-tabut kunid."

OMAR KHAYYaM. 
"Comrades, I pray you, physic me with wine Make this wan amber tace like rubies shine And if I die, use wine to wash my corpse And lay me in a coffin made of vine."

WhiNFIELD.

" Ey hunarha nihada bar kaf-i-dast,

Aibha dar girifta zir-i-baghl, Ta chi khwahi kharidan, ey maghrur,

Ruz-i-darmandagi ba sim-i-daghl?"

Gulistan, chap. 2.

"Thy merits in thy palm thou dost display,

Thy faults beneath thy arm from sight withhold;

What wilt thou purchase, vain one, in that day

The day of anguisti with thy feignéd gold?" EASTwick.

“ Ey ishq-i-bitabahi, ey mutrib-i-ilahi,

Ham pusht wa ham panahi, kafwat laqab na didam."

Drwan-I-Shans-I-T ABriz.

" $O$ indestructible Love ! O divine minstrel

Thou art both stay and refuge; a name equal to thee I have not found."

(NICHOLSON).

"Ey jan za kuja rasidat in dam?

Fy dil za kujast in tapidan?

Ey murgh, bigu zaban-i-murghan

Man danam ramz-i-tu shunidan.

Dil guft 'bikarkhana budam

Ta khana'e ab wa gil pazidan

Az khana'e sun'a mi paridan

Ta khana'e sun'a afridan.

Chun pae na mand mi kashidan

Chun gue'am surati kashidan."

Diwan-I-Shams-1-TABRiz,

"Whence did this breath come to thee, $\mathrm{O}$ my soul ;

Whence this throbbing, $\mathrm{O}$ my heart?

$O$ bird, speak the language of birds

I can understand thy hidden meaning.

The soul answered ' $I$ was in the divine factory

While the house of water-and-clay was a-baking

I was flying away from the material workshop

While the workshop was being created

When I could resist no more, they dragged me

To mould me into shape like a ball." "

(Nicholson).

"Ey kabki khush-khiram, kuja mi-ravi bayist?

Gharra ma shu, ki gurba'e 'abid namaz kard."

HAFIZ ODE, 122.

"O partridge, bird of graceful gait, say whether wouldst thou shape thy way?

Be not so bold, for well we know how the religious cat can pray."

BICKNELL. 
" Ey khush an dana ki pish-i-shah dam

Gah qahr az nukta'e khush mizanad;

Nukta'e chun ab mi arad latif,

Shah ra abe bar atish mizanad."

Jami, Biharistan (3).

" Happy is that learned man who in the presence of the Shah

Utters a pleasant maxim when he is inflamed with anger;

When like water he brings the graceful maxim

To the Shah, it throws water upon fire."

REHATSEK.

“ Ey khunuk chashme ki u giryan-i-u'st,

Ey hamayun dil ki u buriyan-i-u'st,

Az pai har giriya akhir khanda ast

Mard akhir-bin mubarak banda ast."

Jalaluddin Rumi.

" How blessed are the eyes that smart with sorrow's brine,

How blessed is the heart inflamed with love divine !

Contrition's tears are ever hallowed by heaven's smile,

The latter end of all things man should scan awhile."

REDHOUSE.

" Ey khwaja sarmastak shudi, bar ashiqan khunbak zadi,

Mast-i-khudawand-i-khudi, kushti girifti ba khuda,

Bas murgh parran dar hawa az damba fard wa juda

Miayad az charkh-i-qaza ba sina ash tir-i-bala."

Diwan-1-Shams-1.TABRiz.

"Lo! a besotted fool like thee to scorn,

The votaries of love! God's wine has drowned

Thy wits and bidden thee wrestle with thy Lord,

As when a bird his airy flight resumes

Exultingly, nor dreads the distant lure,

Fate to his bosom speeds the shaft of woe."

(Nicholson).

" Ey ki bahangam-i-dard rahat-i-jani mara,

Ey ki batalkha'e faqr ganj-i-rawani mara,

Anche na burdast wahm, an che nadidast fahm,

Az tu bijan mirasad, qibla az ani mara." 'Diwan-J-Shans-I-TAbriz.

"O Thou, who art my soul's comfort in the season of sorrow,

$\mathrm{O}$ Thou, who art my spirit's treasure in the bitterness of dearth,

That which the imagination has not conceived, that which the understanding has not seen,

Visiteth my soul from thee; hence in worship I turn towards Thee."

" Ey ki shakhs-i-manat haqir namud,

(NICHOLSON).

Ta durushti hunar na pindari ;

Asp-i-laghar miyan bakar ayad

Ruz-i-maidan na gav-i-parwari."

Gulistan, chap. I.

"Thou who my stature didst with scorn survey,

Think not that roughness marks the bold in war,

The slender courser in the battle day,

Will the fat stall-fed ox outvalue far."

Eastivick. 
“ Ey mudda'i ki mi-guzari bar kinar-i-ab, Mara ki gharqa em chi dani chi halatast?"

ANWAR-I-Suheili.

" Boaster, thou walkest by the water's brink How canst thou know the state of us who sink?"

"Ey murgh-i-sahar, "ishq za parwana bi-amuz

EASTWICK.

K'an sukhta ra jan shud wa awaz ni yamad, In mudd'ayan dar talabash bi khabar and, K'an ra ki khabar shud, khabarash baz niyamad."

Gulistan, Preface

"O bird of the morn! love of the moth be taught

Consumed it dies, nor utters e'en a cry!

Pretended searchers! of this true love nought

Know ye ;-who know, tell not their mystery."

"Ey rahida jan-i-tu az ma wa man,

EASTWICK.

Ey latifa'e ruh andar mard wa zan.

Mard wa zan chun yak shawad an yak tu'i

Chunki yakha mahw shawad an yak tu'i,

In ma wa man bahr in barsakhti

Ta tu ba khud nard khidmat bakhti."

Jalaluddin Rumi.

"O Thou, Who art exempt from ' us' and 'we'

Who pervadest the spirits of all men and women;

When man and woman become one, thou art that one.

When their union is dissolved, lo Thou abidest.

Thou hast made these ' us' and ' we' for that purpose

To wit, to play chess with them by thyself." Whinfiel.D.

" Ey sakj guzida, manindat ey du-dida,

Andar 'ajam niyamad, andar 'arab na didam;

Chandan biriz bada, $\mathbf{k}^{\prime} a z$ khud shawam piyada,

K'andar khudi wa hasti ghair-i-t'ab na didam."

Diwan-I-Shams-I-TABriz.

"O chosen cup-bearer, $\mathrm{O}$ apple of mine eyes, the like of thee,

Ne'er appeared in Persia, nor in Arabia have I found it ;

Pour out wine till I become a wanderer from myself,

For in self-hood and existence I have felt only fatigue."

" Ey ser! tura nan-i-jawin khush nanumayad,

(NICHOLSON).

M'ashuq-i-man ast an ki banazdik-i-tu zishtast ;

Huran-i-bihishtra duzakh buwad a'raf,

Az duzakhian purs, ki a'raf bihishtast."

Gulistan, chap. r.

"Sated, thou wilt my bariey-loaf repel ;

She whom I love, ill-favoured seems to thee ;

To Edin's Houris Araf * would seem hell,

Hell's inmates ask, - they'll call it heavenly." EAsTwrck.

* The Muhammadan Purgatory. 
"Ey sukhan, kimiya'e tu chist?

Aiyar tura kimiya saz kist?

Ki chandin nigar az tu barsakhtand

Hanuz az tu harfe na pardakhtand;

Na danam chi murghe badin niku'i;

Za ma yadgari ki manad tu'i."

ANWAR-1-SUHEII.s.

"Say, language ! whence is given thy wondrous magic power?

And who the alchemist that turns thee into gold?

Whence spring thy counlless images? While, to this hour

None can thy full resources ever hope to unfold ;

What bird art thou of so much beauty? We

Our sole memorial leave behind in thee."

EASTWICK.

" Ey" tabl buiand bang dar batin hich

Bi tusha chi tadbir kuni waqt-i-pasich

Gulustan, chap. 7 .

"O noisy drum, all emptiness within!

How without food wilt thou thy march begin?"

"Ey tihi dast rafta dar bazar,

Tarsamat baz na awari dastar."

EASTWICK.

"O thou, who goest empty-handed to the market-place,

I fear that thou wilt not bring loack thy turban."

EASTWICK.

"Ey tura khare ba pa na shikasta kai dani ki chist, Hal an sheran ki shamsher baia bar sar khurand?"

ANWAR-1-SUHEILJ.

"Thou in whose foot not e'en a thorn has broken,- how can'st ti,ou

Tell what the warriors feel, whose heads before the sabre bow."

"Ey waqif-i-asrar-i-zamir-i-hama kas,

EASTWICK.

Dar halat-i-ujz dastgir-i-hama kas,

Ya Rabb tu mara tauba dih wa uzr pazir,

Ey tauba dih wa uzr-pazir-i-hama kas."

Omar Khavyam.

"Oh Thou who know'st the secret thoughts of all

In time of sorest need who aidest all, Grant me repentance and accept my plea

O Thou who dost accept the pleas of all." Whinfield.

"Eyyaka wa'an yadhriba lisanuka 'unqaka."

Arabic Provers.

" Beware that thy tongue does not cul thy neck."

"Ey zabardast zir dast azar,

D. STEWAKT.

Garm ta kal bamanad in bazar?

Ba chi kar ayadat jahan dari,

Murdanat bih ki mardum azari."

Gulistav, chap. \&. 
" Oppressor! troubler of the poor! How soon will this thy mart be o'er! What good will empire be to thee? Better thy death than tyranny."

“ Ey zindagi-i-tan wa tawanam hama tu, Jani wa dili, ey dil, wa janam hama tu, Tu hasti-i-man shudi az ani hama man, Man nist shudam dar tu azanam hama tu."

OMAR KHAYYAII.

" My body's life and strength proceed from Thèe, My soul within and spirit are of Thee, My being is of Thee and Thou art mine, And I am thine, since I am lost in Thee." Whinfield. 2

" Fabadir eyyuha 'l'ghumru

Lima yahlu bihi 'lmurru;

Faqad kada yahi 'lumru

Wa ma aqla'ta 'an dhamma;

Wa la tarkan ila 'ddhari,

Wa'in lana wa'in sarra,

Fa tulqa kamani 'ghtara

Ba'fi'an tanfuthu 'ssamma."

Maqamat of Hakiki, chap. ir.

" Hasten, O simple one, to that by which the bitter is made sweet ; for thy life is now near to decay and thou hast not withdrawn thyself from blame. And rely not on fortune though it be soft, though it be gay : for so wilt thou be found like one deceived by a viper that spitteth venom."

Chenery.

"Fabala u'lfata 'ttibau hawa 'nnafsi wa badru 'lhawa tumuhu 'laini."

MaQAMat of HaRiRi, chap. Io.

"The trouble of man is the following of the soul's desire, and the seed of desire is the longing look of the eye."

(Cirenery).

" Fadhaka qari ud-dahri, ma'asha huwalun, Idha sudda minhu mankharun jasha mankharu."

Táabbata Sharkan.

"Against him the wild days dash, he meets them with cunning mind. Is one of his nostrils stopped? he breathes through the other free."

C. J. Lyall.

"Fa 'dhkuru 'llaha kadhikrikum aba'ikum au'ashadda dhikran."

KORAN, chap. 2.

" Remember God as ye remember your own fathers or with a yet more intense remembrance."

(RODWELL). 
" Fa fl'ssama nujumun la 'adada laha

Wa laitha yuksafu illa shshamsu wa' lqamaru ;

Wa kam ala 'lardhi min hadhra wa yablsatin

Wa laitha yurjamu flla ma lahu thamaru ;

Ahsanta dhannaka bi layyami jdh hasunat

Wa lam takhat su'a ma yati bihi lqadr." ALIF:LAILA Wa LAILA.

" We see the orbs of heaven above how numberless they are,

But sun and moon alone eclipsed and ne'er a lesser star;

And many a tree on earth we see, some bare, some leafy green,

Of them not one is hurt with stone, save what has fruitful been.

Think'st thou thyself all prosperous, in days which prosp'rous be,

Nor fear'st the impending evil which comes by heaven's decree?"

TORRENS.

" Fahadhiri 'nnasa w'asahbuhum 'ala dakhils

Wainnama rajulu 'ddunya wa wahiduha

Man la yuawwilu fl'ddunya "ala rajuli."

Al Tughrat.

"He only's fitted for the strife, Which fills the boist'rous paths of life Who as he treads the crowded scenes, Upon no kindred bosom leans."

J. D. Carlyle

"Fahjur mani 'istaghbaka hajra "quila, Wa habhu k'almalhudi fi ramsihi."

Maqamat of Hariki, chap. 4.

"Sunder with the sundering of hate from one who would make thee fool and hold him as one entombed in the grave."

Chenery.

" Fahm-i-sukhan chun na kunad mustam'i

Quwat-i-tab'a az mutakallime ma jui ;

Fushat-i-maidan-i-iradat biyar

Ta ba nizd-1-mard-1-sukhangui gui."

Gulistan, chap. 2.

" Expect not from that speaker eloquence,

Whose words his audience cannot value well.

With a wide field of willingness commence,

Then will the orator the ball propel."

(EASTWICK).

"Fahm wa khatir tiz kardan nist rah Juz shikasta minagirad fazl-1-shah."

Jalaludin Rum.

"Thee to thy goal wit-sharpening will not bring, Only the broken-hearted find"the favour of the king."

" Fallsufl divra munkir shawad, Dar haman dam sakhra-e-div shawad;

Gar na didi divra khudra bibin, Bi junun na bud kabudi bar jabin."

Jalaluddin RUm. 
"The philosopher denies the existence of the Devil At the same time he is the Devil's laughing-stock. If thou hast not seen the Devil, look at thyself, Without demon's aid how came that blue turban * on thy brow."

(WHINFIELD).

"Fa'innaki lau sa'alti baqa'i yaumin 'ala 'lajali 'lladhi lam tuta'i

Fa sabran fi majali 'lmauti sabran fa ma nailu 'lkhuludi bimustata'i."

KATARI.

"Yea, if but a day of life thou shculdst beg with weeping

Beyond what thy doom appoints, thou wouldst not gain it, Be still then and face the onset of death, high-hearted, For none upon earth shall win to abide for ever." C. J. Lyal.L.

"Fa'inna 'ssaida man wuidha bighairihi."

GhazZALI.

"Happy the man who lets hinself be warned by the example of others."

"Fain takuni' l'aiyyamu fina tabaddalat bibusa wa nu'ma w'alhawadithu taf'alu

Fa ma layyanat minna fatatun wa la dhallatana lillati laisa tajmulu."

"And suoth, if the changing days have wrought us-their wonted way, a lot mixed of weal and woe yet one thing they could not do: They have not made soft or weak the stock of our sturdy spear, they have not abased our hearts to doing of deeds of shame." C. J. Lyal.L.

"Faizi 'lruhu 'lqudus ar baz madad farmayad,

Digaran ham bikunad an che Masiha ml-kard." HAFIZ Ode, 123.

"If by the Holy Spirit's grace the gift again be won

The works which the Messias wrought by others may be done."

BICKNELL.

"Fakaifa tattaquna, in kafartum, yauman yajalu 'Iwildana shiban, 'ssama'u munfatirun bihi kana w'aduhu maf'ulan."

KORAN, chap. 73 .

"And how, if ye believe not, will you screen yourselves from the day that shall turn children grey-headed? The very heaven shall be rent asunder by it : this threat shall be carried into effect." (RODWELL).

" Fakam tasdiru fi 'ssahwi, wa takhtalu mina 'zzahwi,

Wa tansabbu 'ila 'llahwi, ka'anna 'lmauta ma 'amma?

Wa hattama tajaflka wa 'ibta' $u$ talafika

Tiba'an jama'at flka alyuban shamluha 'ndhamma;

Idha 'askhatta maulaka, fama taqlaqu min dhaka,

Wa 'in 'akhfaqa mas'aka, taladha'aita mina 'lahamma."

Maqaiat of HaRiRi, chap. ir.

* Blue turbans were considered a sign of hypocrisy. 
" How long wilt thou be bewildered in carelessness, and walk proudly in vanity, and go eagerly to diversion, as if death were not for all,

Till when will last thy swerving, and thy delaying to mend habits that unite in thee vices whose every sort shall be collected in thee?

If thou anger thy Master, thou art not disquieted at it ; but if thy scheme be bootless, thou burnest with vexation."

(CHEHERY).

"Fa laisa takhfa ala 'rrahmani khaflyatun

In 'akhlasa 'labou fl 'tta'ati au daja,

Wa badiri 'imauta bi'lhusna tuqaddimuha

Fa ma yunanahu d'ai 'Imauti "in faja." Maqanat of Hariki, chap. 31.

"Io ! no hidden dead shall remain hidden from the Compassionate

Whether the servant be sincere or shamming

Steal a march on death by good deeds sent before: death's sudden summons when it comes is not put off." (STEIxGass).

"Falakra ghair az in khud nist kare

Ki yare ra juda sazad za yare."

ANIWAR-J-SUHEILI.

"This seems the task by which Fate's occupied

To sever love, and friend from friend divide." EAsTwick.

" Falak za hal-i-pareshan-i-ma chi gham darad, Agar chiragh bimirad, saba chi gham darad."

ANWAR-I-SUHEILJ.

"For our lorn state what cares the tranquil sky?

What cares the morning though the taper die?"

EASTwick.

"Fala 'qtahama 'l'aqabata, wa ma 'adraka ma 'l'aqabata faklku raqabatin au 'it'amun $\mathrm{fl}$ yaumin dhi masghabatin yatiman dha maqrabatin au miskinan dha matrabatin."

KORAN, chap. go.

"Yet he (man) attempteth not the steep. And who shall teach thee what the steep is? It is to ransom the captive, or to feed in the day of famine the orphan who is near of kin, or the poor that lieth in the dust."

(RODWELL).

“Fa la tahsabi 'anni takhashsh'atu b'adakum lishalan wa la 'anni mina 'Imauti 'afraqu

Wa la 'an nafsi yazdahiha waidukum wa la 'annani bi 'lmashi fl 'iqaidi akhraqu."

JAFAR IBN ULEAH.

"Nay think not that I am bowed by fear away from you,

Or that I tremble before the death that stands so nigh,

Or that my soul quakes at all before your threatenings

Or that my spirit is broken by walking in these chains."

" Fa la taktumunna 'llaha ma fl sudurikum

C. J. Lyall.

Liyakhfa wa mahma yuktami 'llaha y'alim

Yuakhkhar fayudh'a fl kitabin fayuddakhar

Liyaumi 'lhisabi au yuajjai fa yunqam."

ZUHAIR. 
"Attempt not to conceal from God the designs which your bosoms contain; for that which you strive to hide, God perfectly knows. He sometimes defers the punishment but registers the crime in a volume and reserves it for the day of account ; sometimes He accelerates the chastisement and heavily it falls."

SiR W. JoNes.

" Fa la tathiq biwamidhin min barqihi fahuwa khullaba,

W'asbir idha hu 'adhra bika 'lkhutuba w'allaba,

Fama 'ala tibri 'arun fl 'nnari hina yaqallaba."

MAQAMAT OF HARIRI, chap. 2.

" Trust not the gleam of fortune's lightning, for it is a deceitful gleam, But be patient if it hounds calamities against thee, and drives them on, For there is no disgrace on the pure gold, when it is turned about in the fire."

(Chenery).

"Fa laula fadhlu 'llahi 'alaikum warahmatuhu lakuntum mina 'lkhäsirin."

Koran, chap. 2. $\quad v \cdot 6$ I

"But for God's grace and mercy towards you, ye had surely been of the lost."

(RODWELL).

\section{"Fa la yakhda 'anka lumu' 'ssarab wa la t'ati 'amran idhama 'ashtabahi." \\ MAQAMAT OF HARIRI, chap. 6.}

" Let not the glare of the mirage beguile thee; undertake not that which is doubtful."

(Chenery).

"Fa ma adri, idha yammamtu ardhan

Uridu'l khayra, ayyuhuma yalini :

A'al khayru 'lladhi ana abtaghihi

Ami' sh-sharru 'lladhi huwa yabtaghini." Al-MuthakkiBu L'ABdi.

"And I know not when bound for the land of my quest if my portion shall be

The good which I hope for and seek, or the evil that seeketh for me."

(E. G. Browne).

"Fa ma kana Qaisun hulkuhu hulka wahid wa lakinnahu buniyanu qaumin tahaddama."

ABDAH IBN AT-TABIB.

"When Qais died it was not one who went down the way of death ;

A people it was, whose house with his death in ruin fell."

C. J. LyalL.

"Fama lahum 'ani 'ttadhkirati m'uridhin ka' annahum humurun mustanflratun farrat min qaswaratin."

KORAN, chap. 74 .

"What hath come to them that they turn aside from the warning as if they were affrighted asses fleeing from a lion?"

(RODWELL). 
“F”ama 'imalu musta'arun laitha fl halaktihi 'arun w'al amalu ka 'ssahaba minha' ssayyaqu wa minha 'rayyaqu."

A MU'L ALA.

"Wealth is only lent us and there is no shame in losing it. Nnd hopes are like clouds, some of which drift while others shed water."

D. S. Makgoliouth.

"Faman yuridi llahu 'an yahdiyahu yashrah sadrahu lilislami wa man yurid 'an yudhillahu yaj'al sadrahu dhayyiqan harajan ka'annama yass'adu fl' ssama4."

KORAN, chap. 6 .

"And whom God shall please to guide, that man's breast will He open to Islan ; but whom He shall please to mislead, strait and narrow will He make his breast as though he were mounting up into the very heavens."

(RODWELL).

"Fa na'udhib 'illah' 'Iwahid mina 4shar alnubl w'al'ud."

ABU'L. At.A.

"God protect us from attending concerts and music."

“F”anqad liman 'adha 'zzimam bikafflhl,

D. S. Margoliouth.

Wa taghadha in 'algha 'rriayata au lagha,

Wa'r'a 'Imarara idha d'aaka lira'ihi,

Warid 'lajaja idha hamaka 'ssiyyagha." Makamat of Hakik! (21).

"Obey thou him in whose hand is the leading cord; cast down thine eye if he neglect observance or speak vainly. And graze on bitter pasture when he calls thee to the grazing on it, and water at the salt well when he forlids thee the sweet."

(ChenRry).

"Faqadttu zamana 'lwasli wa' l maru jahilun

Bi qadri ladhidh' 'l'aishi qabla'l masa' ibi."

Gulistan, chap. 5 .

"I have lost the season of union and man is ignorant

Of the value of the joys of life previous to the trials of separation."

"Farbahat karda base ni'amat wa naz .

Pi.nTts.

Z'an biandesh ki chun khwahi raft:

Ba chunin jussa nadanam ki chi shan

Ba dar-i-marg darun khwaht raft."

JAMi (BEHARISTAN).

"When thou growest fat in plenty and enjoyment

Think of this also, - how thou art to escape

With such a large body I know not how thou wilt enter the door of death."

" Fareb khush az khashm na khush bih ast,

Bar afshandan ab za atish bih ast, Murade ki dar lutf gardad tamam,

Chł bayad sue qahr dadan lagam?"

ANwar-1-Suheil., 
"Sweet guile is better than unpleasant ire

Tis best to sprinkle water upon fire.

When thou by gentle means thy wish canst gain

Why towards anger give unchecked the rein?"

"Farumandan-i-shahr-i-khud ba khasan

EASTwICK.

Bih az shahriyari ba shahr-i-kasan;

Bashahr-i-kasan garchi bashad bihi

Dil az mihr-i-khana nabashad tihi."

Nizani.

"And what though, far from home we share

Earth's hollow pomps that perish?

The friends the loves of youth are there

And these the heart will cherish :

Its strings will twine around the home

Where we were nursed howe'er we roam."

" Farq ast miyan anki yarash dar bar

(FALCONER).

Ba anki du chashm-i-intizarash bar dar."

Gulistan, chap. I.

"Wide is the space 'twixt him who clasps his love

And him whose eyes watch for the door to move."

"Farq-i-shahi wa bandagi barkhast

(EASTWICK).

Chun qaza'e nabishta ayad pish ;

Gar kase khak-i-murda baz kunad,

Nashinasad tawangar az darwish."

(Gulistan, chap. 1).

"Lost is the difference of king and slave,

At the approach of destiny's decree :

Should one upturn the ashes of the grave,

Could he discern 'twixt wealth and poverty."

(EASTWICK).

" Faryad az in umr-i-subuk, zinhar az in khwab-i-giran

Ey dil sue dildar shu, ey yar sue yar shu;

Ey pasban bedar shu, khufta nashayad pasban."

Diwan-I-Shaus-I-TAbriz.

"Alas for this life so light, beware of this slumber so heavy,

$\mathrm{O}$ soul seek the Beloved, $O$ friend seek the Friend

O watchman be wakeful ; it behoves not a watchman to sleep."

"Faryad ki raft 'umr bar behuda,

(NichOLSON).

Ham luqma haram wa ham nafs aluda,

Farmuda'e nakarda siyah rue'am kard

Faryad za kardha'e na farmuda."

Omar Khayyam.

"Alas! my wasted life has gone to wrack, What with forbidden meats and drinks, alack!

And leaving undone what 'twas right to do, And doing wrong, my face is very black." Whinfield. 
" Fasad-1-charkh na binand wa nashnawand hama,

Ki chashmaha hama kurast wa gushha hama kar,

Basa kasa kl mah wa mlhr bashadash balin,

Ba "aqlbat zi gil wa khisht gardadash bistar."

HAFIZ.

"None see nor hear the malice of the sky

Each ear is deaf and blind is every eye

Oft those who moon and sun their pillow thought

Have later bricks and clay too gladly sought." BiCKNELL.

" Fa' sbir 'ala ma yaquiuna wa sabblh bihamdi rabbaka qabla tulu' 'shshamsi wa qabla ghurubiha wa min änä'i 'llaili."

Koras, chap. 20. $\mathrm{V} \cdot 13 \mathrm{u}$

" Put up then with what they say; and celebrate the praise of thy Lord

before the sunrise, and before its setting; and sometime in the night do thou praise Him."

(RODWELL).

"Fash miguyam wa az gufta'e khud dilshadam,

Banda'e 'ishqam wa az har du jahan azadam,

Tair-1-gulshan-i-qudsam chi diham sharh-1-firaq

Ki dar in damgah-1-hadisah chun uftadam?"

HAFIZ ODE, 4 I6.

"Aloud I say it and with heart of glee, 'Love's slave am I and from both worlds am free.'

Can I, the birl of sacred gardens tell, Into this net of chance how first I fell?"

(BICKNELL).

"Fata'antu 'anhu 'lkhaila hatta tanaffasat, wa hatta 'alani haliku 'llaun' 'aswadi

Qitala 'marian 'aasa 'akhahu binafsihi wa y'alamu .anna 'Imar'a ghuiru mukhalladi."

DURAID.

"I plied spear above him, till the riders left their prey,

And over myself black blood flowed forth in a dusky tide;

I fought as a man who gives his life for his brother's life,

Who knows that his time is short, that death's doom above him hangs."

“Fa ya dhulla 'rrajali baghairi malin,

C. J. Lyali.

Wa lau kanat fadhailuhum ka shamsi."

Alif Laila wa Laila.

"Let men have attainments that shine like the sun

They're but poor abject fellows, if money they've none."

" Faya mautu zur anna 'lhayata dhamimatun,

TORRENS.

Idha anhattati 'lbazatu wa urtafa 'lbattu,

Fa la ajaban in kunta ayanta fadhilan

Faqiran wa dha nagsin bidaulati yastu."

Alif Laila wa Laila.

"Oh how vile e'en to thee Death, this life we must own

When the mallard flies high, while the hawk is struck down, Is it strange to see wisdom ask alins at the gate And within the foul lord it in insolent state?"

TORRENS. 
" Faza shu chu bini dar-i-sulh baz, Ki nagah dar-i-tauba gardad faraz ; Marau zir bar-i-gunah, ai pisar, Ki hummal "ajiz shawad dar satar."

BOSTAN OF S'ADl, chap. 9.

"Rise and come forward when thou seest the door of peace open For the door of repentance suddenly becomes shut.

Oh son! go not beneath the load of sin

For the burden-carrier becomes wcaried on a journey."

(C'larke).

"Fazl wa hunar za'ist ta nanumayand, "Ud bar atish nihand wa mushk basayand."

Gulistan, chap. 3 .

"Merit and skill are weak while in the husk Aloes they cast on fire and crush down musk."

(EASTWICK).

"Feridun farrukh firishta nabud,

Za mushk wa z'ambar sarishta nabud ;

Ba dad wa dahish yaft an nikui

Tu dad wa dahish kun, Feridun tu'i."

FiRdAUSI.

"The happy Feridun was not an angel,

He was not formed of musk or ambergris,

He gained his reputation by justice and liberality,

Be thou just and liberal, and thou wilt be a Feridun."

Sir W. JONES.

"Feridun guft naqqashan-i-Chin-ra

Ki pairamun-i-khargahash biduzand,

Badanra nik dar ey mard-i-hushyar,

Ki nikan khud buzurg wa nik ruzand."

Gulistan, chap. 8.

"Said Feridun to China's men of art

'Round my pavilion's wall's embroider this,

'If thou art wise, to bad men good impart

The good enough of honour have and bliss." EAstwick.

“Fi akthari ayyami kuntu k'-abdin illadhi yakunu jalisan tahta sayfin 'ullika bi-sha'ratin wahidatin wa lam yadri mata yanzilu 'aleyhi fi'l-hin, aw ba'da hin."

BEHA-ULLAH.

" For most of my days I was a servant who is sitting under a sword which is suspended by a single hair, and he knoweth not when it shall descend upon him at once or after a while."

(E. G. Browne).

" Fikreki ba kar-i-khud tura bayad kard,

Bahri chi ba digare riha bayad kard,

Wa an gah ki badin nau' khatae kardi,

Dar kardan-1-digaran chira bayad kard."

ANwar-1-SuheILr. 
"Why to another's care consign

Schemes that thine own exertions claim ?

And when thou hast been thus supine

Why on another hang the blame?"

Eastivick.

" Fikr-1-ma tir ast az Hu dar hawa,

Dar hawa kal payad, ayad ta khuda."

JALAL.UDdIN RUMI.

"Thought is an arrow shot by God into the air How can it stay in the air? It returns to Gorl."

WHINFIELD.

" Firagh-i-dilat hast wa nirawi tan,

Chu maidan farakh ast gue bizan,

Man an ruz ra qadr nashinakhtam,

Bidanistam uknun ki dar bakhtam."

BOSTAN OF S'ADI, chap. 9.

" Thou hast leisure of mind and strength of body

When the plain is spacious, strike the ball of life ;

I understood not the value of that day of youth

Now I know it when I have played it away."

Clarke.

"Firaq-1-dustan didan nishane bashad az duzakh

Ma'adh 'ullah ! ghalt kardam, ki duzakh z'u nishan bashad."

Anwar-I-Suheil.

" 'Tis sure a shadowing forth of hell from friends to separate

Forgive me, heaven ! for my error,-hell is but its entrance gate."

EAstwick.

"Firishta khue shawad admi ba kam khurdan

Wa gar khurad chu bahaim biuftad chu jamad :

Murad-1-har ki bar ari muti-i-amr-1-tu shud

Khilaf-1-nafs ki gardan kashad chu yaft murad."

Gulustan, chap. 7 .

"By abstinence man might an angel be

By surfeiting his nature brutifies;

Whom thou obligest will succumb to thee, Save lusts, which, sated, still rebellious rise."

" Firishta rust ba ilm wa bahima rust ba jahl

(EAstwick).

Darin miyan ba tanaz'a bamand mardumzad ;

Gahe hami kashadash ilm sue 'allyyin

Gaheash jahl ba pasti ki har chi bada bad."

DiWan-I-ShaMS-I-TABRIZ,

"The angel grew with knowledge, the beast with ignorance,

Man remained in dispute between them.

Sometimes knowledge draws him to the seventh heaven,

Sometimes ignorance drags hin down, so that (he says) 'Come what will !" "

(Nichol.son). 
"Firistada bayad ki dana buwad, Ba guftash diler wa tawana buwad, Az u har chi pursand goyad jawab, Ba nau'e ki bashad tariq sawab, Sukhanha'e khwish ashkara kunad, Bud insan ki majlis taqaza kunad Bisa kas ki az yak hadis durusht Baham zad jahane wa khalqe bakusht, Yake digar az gufta'e dil-pasand Miyan du zidd tarah-i-yari flgand."

Anivar-i-Suheil.i.

"Wise must he be by monarchs sent And bold in speech and eloquent; He must reply to all they ask, So as to best fulfil his task. In speaking it must be his aim For those who hear his speech to frame. Oft has a word too roughly said The world embroiled and heaped with dead; And oft another soft and mild Two nations, hate has reconciled."

EAstwick.

"Firumandaganra dirun shad kun,

Za ruz flrumandagi yad kun;

Na khwahinda'i bar dar-i-digaran

Ba shukrana khwahinda az dar maran."

Bostan of S‘Adi.

" Make the hearts of those dejected happy,

Remember the day of helplessness (the judgment day)

Thou art not a beggar at the doors of others,

In thanks to God, drive not a beggar from thy door."

Cl.ARKe.

"Fursate dan; ki za lab ta badahan in hama nist, Az tahattuk ma kun andesha wa chun gul khush bash, Z'anki tamkin-i-jahan-i-guzran in hama nist."

HAFIZ OdE 88.

"Enjoy! 'twixt lip and mouth the bounds as nothing are If humbled, care not ; as the rose be gay, Life's honours which pass soon away, as nothing are."

Bicknell.

"Fursat nigar, ki fltna chu dar 'alam uftad,

Haflz ba jam mai zad wa az gham karan girift." Hafiz, Odes.

" Regard opportunity. For when uproar fell upon the world, Hafiz struck at the cup and through grief took the corner of retirement."

(CLARKE).

"Fursat shumar suhbat k'az in du raha manzil Chun bigzarem digar natawan baham rasidan." HAFIz, Odes. 
"Profit by companionship ; this two-dorred house (i.e., life) forsaken, No pathway that can thither lead in future time is taken."

(BICKNEI,L).

" Fursat shumar tariqa'e rindi, ki in nishan

Chun rah-i-ganj bar hama kas ashkara nist."

HAV́IZ.

" Reckon as plunder the path of profligacy. For this track like the path to the hidden treasure is not evilent to every ons."

Clarke.

“Fusurda manad yakhe k'an ba zir-i-saya buwad, Na did shi'shi'a'e aftab-i-tabanam;

Tabassum-i-rukh-i-khurshed har yakhe ki badid Bakhwish balad wa guyad ki ab-i-haiwanam."

Diwan-l-Shams-1.TAbriz.

"The ice that remains in the shade is frozen It saw not the brilliance of my glowing sun. All ice that has seen the smile of the sun's face Grows itself again, and says "I am the water of life."

(NICHOLSON).

"Futada dar sar-i-Haflz hawa'e chun tu shahi,

Kamina banda'e khak-i-dar-i-tu budi kaj."

HAFIZ.

"A Shah no other than thyself aspiring Hafiz craves;

Oh! were he in thy doorway's dust one of thy common slaves."

BickNell.

"Futad atish-i-subh dar sukhta

Ba ek dam jahane shud afrukhta

Tu gufte ki dar khatt-i-zangbar

Za ek gusha nagah dar amad tatar."

BOSTAN OF S'ADI.

"The fire of the morning fell upon tinder

A world became in a moment illumined

Thou wouldst have said that in the country of Zanglar

A Tartar had suddenly issued from a corner."

Clarke.

"Gar anha ki mi danami kardami, niku sirat wa parsa budami."

GuListan, chap. 2.

" Had but my deeds been like my words, ah, then

I had been numbered too with holy men." (EAsTwICK).

" Garat hawast ki mashuq nagsilad paiman,

Nigah dar sar-i-rishta ta nigah darad."

HaFtz.

"If it is thy desire that the leloved should not break the covenant, Keep thy end of the thread that IJe may keep his.end."

(NicholsoN). 
" Gar az kuh giri wa na nihi ba jae, Saranjam kuh andar ayad za pae."

ANIVAR-I-SUheILI.

"Dig from a hill and nought return

Thou soon that hill wouldst overturn." EASTwICK.

" Gar bad ast az wai itibar ma kun, War niku hast, i timad ma kun."

Jami Bibaristan 2.

"If she be bad, confide not in her And if she is good, trust her not." ReHatsek.

" Gar ba jae nanash andar sufra budi aftab,

Ta qiyamat ruz-i-rushan kas na didi dar jahan."

S‘ADI.

"If the sun upon his table cloth instead of dry lread lay

In all the world none would behold again the light of day."

EAstivick.

" Gar ba qiyas-i-fazl bagashti madar-i-charkh, Juz ba maqarr-i-mah nabudi maqar mara, $\mathrm{Ni}$ ni, ki charkh wa dahr nadanand qadr-i-fazl, In gufta bud gah-i-jawani pidar mara." NAsiR-I-K hUSRAw.

"Were the turns of the wheel of fortune proportioned to worth alone O'er the vault of the lunar heavens would have been my abode and throne

But no! for the worth of wisdom is lightly esteemed in sooth

By fickle fate and fortune as my father warned me in youth."

E. G. Browne.

" Gar yakera tu kamran bini,

Digrera dil az mujahida rish,

Ruzake chand bash, ta bikhurad

Khak maghz-i-sar-i-khiyai andish." : . GuLisran, chap. I.

"To-day thou markest one flushed with success

Another sick with struggles against fate.

Pause but a little while, the earth shall press

His brains that did such plans erst meditate."

(EASTWICK).

"Gar gauhar-i-ta'atat nasiftam hargiz,

Gard-i-gunah az chihra naraftam hargiz, Naummid niam az bargah-i-karmat, Zira ki yaki ra du na guftam hargiz."

Omar Khayyam.

" No pearls of righteousness do I enlace,

Nor sweep the dust of sin from off my face,

Yet since I never counted one as two,

I do not quite despair of heavenly grace."

(WhiNFIELD). 
"Gar hunare dari wa haftad "aib,

Dust na binad bajuz an yak hunar."

A.NWAR-I-SUheILI.

" Iladst thou one virtue, faults three-score and ten .

Nought but that virtue shines in friendship's ken."

EASTWICK.

"Gar gazandat rasad za khalq maranj,

Ki na rahat rasad za khalq na ranj,

Az khuda dan khilaf-i-dushman wa dust,

Ki dil-i-har du dar tasarruf-i-ust ;

Garchi tir az kaman hamiguzarad,

Az kamandar binad ahl-i-khirad."

Gulistan, chap. 1 .

"Art thou by creatures injured? do not grieve;

None joy or pain from creatures e'er receive.

Know that by God both friends and foes are given,

Yes! for the hearts of both are swayed by heaven.

What though the arrows from the bowstring fly,

The wise well know the archer's agency." (EAsTlick).

" Gar hunarmand za aubash jafa'e binad,

Ta dil-i-khwish niyazarad wa darham nashawad;

Sang-i-bad gauhar agar kasae zarrin shikunad,

Qimat-1-sang niafzayad wa zar kam na shawad."

Gulistan, chap. 8.

"What if a vagabond on merit rail?

Let not the spirits of the worthy fail

A common stone may break a golden cup ;

Its value goes not down, the stone's not up."

EASTwick.

"Gar in mudd'ai dust bishinakhte,

Paikar-i-dushman na pardakhte."

Bostan of S'ADI, chap. 4 .

"If this claimant had known the Friend (God)

He would not have engaged in contest with the enemy."

(Clarke).

"Gar jahan pishat buzurg wa be bandist,

Pish qudrat zarra'e medan ki nist;

In jahan khud khabs janiha shumast,

Hin duvid an su ki sahara shumast."

JALALUDDIN RUMI.

"In man's esteem the world is vast without an end

With Power Infinite compared, a grain of sand

The world's around the suul a dismal prison den

Arise! Escape! Regain the felds at large! Be men!"

(REDHOUSE). 
"Gar kase wasf-i-u za man pursad, Be-dil az be-nishan che goyad baz? Ashiqan kushtigan-i-m 'ashuq and, Bar na ayad za kushtigan awaz."

Gulistan (Preface).

"If one His praise of me would learn, What of the traceless can the tongueless tell? Lovers are killed by those they love so well; No voices from the slain return."

(EASTwICK).

" Gar kutahi pae chubin maband

Ki dar chashm-i-tiflan numai buland." BOSTAN of S'ADI, chap. 5 .

" If thou art small, fasten not on wooden feet, That thou mayest in children's eyes appear tall."

" Gar kushi war jurm bakhshi,

CiLA'KE.

Rue wa sar bar astanam;

Bandara farman nabashad

Har chi farma'i bar anam."

Gulistan, chap, 2.

"Whether Thou wilt slay or spare me, at thy door my head I lay

To the creature will belongs not, Thy commandment I obey."

" Gar man za mai maghana mastam, hastam,

(EASTWICK).

War kafir wa gabar war but-parastam, hastam,

Har taifa baman gumane darand,

Man zani khudam chunanki hastam, hastam."

OMar Khayyam.

" Am I a wine-bibber? What if I am?

A giaour or infidel? Suppose I am?

Each sect miscalls me but I heed them not,

I am my own, and what I am, I am." (Whinfield).

"Gar mara zar bakushtan dihad an yar-i-'aziz

Ta na gu'i ki dar an dam gham-i-janam bashad;

Guyam az banda'e miskin chi gunah sadir shud,

K'u dil azurda shud az man? Gham-i-anam bashad."

Gui.istan, chap. 2.

" If that Loved One should say me cruelly

Thou shouldst not say, e'en then, I feared to die

I'd ask 'What fault has thy poor servant done

"Tis for thine anger that I grieve alone." " (EASTwICK).

"Gar na bashad gandam mahbub nush

Chi burd gandam numa jau farush?

Pas magu k'in jumla dinha batiland

Batilan ba bu-i-haqq dam dil and ;

Pas magu jumla khiyal ast wa zalal

Bi haqiqat nist dar alam khiyal.

Darmiyan dalq-pushan yak faqir

Imtihan kun wa an ki haqq ast, an bigir." JAlaluddin RuMr. 
"If wheat were not valued as sweet and good for food,

The cheat who shows wheat and sells barley would make no profit.

Say not then that all these creeds are false

The false ones ensnare hearts by the scent of truth.

Say not that they are all erroneous fancies

There is no fancy in the universe without some truth.

In the crowd of rag-wearers there is one faqir,

Search well and find out that true one."

(WHINFIELD).

" Gar nabudi ummid-i-rahat wa ranj,

Pae darwesh bar falak budi;

War wazir az khuda bitarsidi,

Hamchunan k'az malik, malak budi."

Gulistan, chap. I.

" Could the holy darwish cease from worldly joy and sorrow,

On the sky his foot would be ;

And the vizier for himself angelic light would borrow,

Served he God as royalty."

(EASTWICK).

" Gar nabudi amr murr,

War nabudi khub wa zisht wa sang wa war,

War nabudi nafs wa Shaitan wa hawa,

War nabudi zakhm wa chalish wa dagha,

Pas ba che nam wa laqab khandi malik

Bandagan $1 \mathrm{khwish}$ ra mantahik!

Chun ba gufti 'ey sabur' wa 'ey halim'

Kai ba gufti 'ey shuj' $a$ ' wa 'ey karim ?'"

JALALUdDIN RUMI.

"If there were no bitter things,

And no opposition of fair and foul, stone and pearl,

And no lust or Satan or concupiscence,

And no wounds or war or fraud,

Pray, $\mathrm{O}$ destroyer of virtue, by what name and title

Could the King of kings address his slaves?

How could He say 'O temperate' or 'O meek one,'

Or " $\mathrm{O}$ courageous one' or " $\mathrm{O}$ wise one."

" Gar nashinad firishta'e ba div,

Jalaludin RUMi.

Wahshat amuzad wa khiyanat wa riv;

Az badan nekui niyamuzi,

Niyad za gurg pustin duzi."

Gulistan, chap. 8.

" With demons did an angel take his seat,

He'd learn but terror, treason and deceit ;

Thou from the bad will nothing learn but ill

The wolf will ne'er the furrier's office fill." (EAsTwick).

" Gar niayad ba gush-i-raghbat-i-kas

Bar rasulan paiyam bashad wa bas."

Gulistan, chap. B.

"What though men hear not? Messengers of heaven

Can but discharge their duty : and it is

'To tell their message."

(EAstwick). 
"Gar parwani darakht-i-karm, Bar-i-niknami khuri la-jarm, Agar khud hamin surate chun tilism Bi miri wa ismat bimirad chu jism."

Bostan of S'adig chap. 4 .

"If thou causest thyself to cherish the tree of liberality Thou mayest assuredly enjoy the fruit of a good name. But if thou art a mere semblance, Thou wilt die, and thy name like thy body will die."

(Clarke).

"Gar ranj pishat ayad wa gar rahat, ey hakim, Nisbat makun baghair, ki inha khuda kunad."

HAF12, ODE, 208.

" lic misery thy portion here, O Sage, or be it bliss

lefer it not to other men : 'tis God who orders this."

BICKNELL.

" Gar ru-e-zamin ba jumia abad kuni, Chandan nabud ki khatire shad kuni, Gar banda kuni baiutf azadera, Bihtar ki hazar banda azad kuni."

OMaR K Kayyam.

"Better to make one soul rejoice with glee, Than plant a desert with a colony, Rather one freeman hind with chains of love, Than set a thousand prisoned captives free."

(WHINFIELD).

"Gar sang hama l'al-i-Badakhshan budi, Pas qimat-i-l'al wa sang yaksan budi."

Gulistan, chap. 8.

"Were each stone such ruby as is found in Badakhshanyan earth, Ilow then would the ruby differ from the pebble in its worth?"

Eastwick.

"Gar saru raft, narwan hast;

War lala namanad, yasmin hast."

ANwar-I-Suheili.

"What, has the cypress perished? but Narvan's flowers the eye still bless, The tulips gaudy bloom is o'er, then mark the jasmine's loveliness."

EASTWICK.

"Gar shadi-i-khwishtan badan medani

K'asuda dilira ba ghami binshani,

Dar matam-i-aql-i-khwish bashi hama umr,

Medar musibat, ki "ajab nadani."

Omar Khayvam.

"O thou who for thy pleasure dost impart

A pang of sorrow to thy fellow's heart,

Go! mourn thy perished wit and peace of mind

Thyself hast slain them, like the fool thou art."

WHINFIELD. 
" Gar tu khwahi k'u tura bashad shakkar,

Pas u-ra az chashm-i-ashiqan nigar;

Mangar az chashm khudat an khub ra,

Bin ba chashm-1-taliban matlub ra."

JALAi.UDDIN RUMi.

"If you desire that God may be pleasing to you,

Then look at Him with the eyes of those that love Him.

I.ook not at that Beauty with your own eyes,

Look at that Object of desire with His volaries' eyes."

(WHINFIELD).

" Gar tu ra daya bitarsanad za ab

Tu matars wa sue darya an shitab,

Tu bate bar khushk wa bar tar zinda'i

Na chu murgh khana khana kanda'i."

JalaludDin RUMI.

"Though thy nurse may frighten thee away from water

Do thou fear not, hut haste on into the ocean;

Thou art a duck, anil flourishest on land and water,

And dost not like a don estic fowl dig up the house."

(WHINFIELD).

“ Gauhar-i-pak buwad jauhar-i-hishmat, lekin

Ba amal kush, ki hishmat na ba asl wa nasabast." Hafiz, Ode, ro4.

" High birth may be a pearl of lustre, but let thine effort be

To rise by deeds. Distinct is greatness fronı birth and pedigree."

BickNel.L.

" Ghail-i-Haqq jan nabira yar nest

Ba qabul wa radd khalqash kar nest."

JaLALUddin Rumi.

"The soul of the prophet cares for nought but God,

It has nothing to do with approving or disapproving His works."

(WhINFIELD).

"Ghalani 'ddharu bi wafri 'lghanl falaisa li malun siwa irdhi."

HitTan.

"Fortune has rent away my plenteous store,

Of all my wealth honour alone is left."

C. J. Lyal.L.

" Ghali binafsi "irfani biqimatiha, .

Fasuntuha 'an rakhisi 'lqadri mubtadhali,

Wa 'adatu 'nnasii 'an yuzha bijauharihi

Wa laisa y'amalu illa fl yaday batali."

Al Tughrai.

"My soul from every tarnish free

May boldly vaunt her purity,

However keen, however bright,

The sabre glitter to the sight,

Its splendour's lost, its polish vain,

Till some bold hand the steel sustain."

J. D. CARI.Yl.F. 
" Ghalt wa sahw bar man wa tu rawast Bar jahan-i-afrin ghalt na rawad."

Anwar-I-Suheill.

" Mistakes and faults may spring from thee and me;

In earth's creator error cannot be."

EASTIVICK.

" Ghame k'az pish-i-shadmani buri

Bih az shadi k'az pasash gham khuri."

Gulistan, chap. 8.

"Better feel sorrow ere we gladness know

Than to be happy and then suffer woe." (EASTivick).

" Gham-i-farzand wa nan wa jama wa qut

Bazat arad za sirat-i-malkut.

Hama ruz ittifaq misazam

Ki bashab ba khudae pardazam,

Shab, chu 'aqd-i-namaz mibandam,

Chi khurad bamdad farzandam."

GUListan, chap. 2.

"Care for thy sons, bread, raiment and support

Will drag thy footsteps back from heaven's court.

All day I must the just arrangements make,

To God at night myself in prayer betake.

Night comes; I would to prayer myself confine

But think "How shall my sons to-morrow dine?"

(EASTIVICK).

“ Gh m ma khur k'az in chaman shakh-i-gule pazhmurda shud, Rue nasrin taza ast, wa j‘ad sambal tabdar." ANwar-i-SuHEILI.

"Grieve thou not thou in this garden branches of the rose are lead, Still the hyacinth curls its tresses, still the Nasrin lifts its hearl."

" Gham wa shadmani na manad wa lek Jaza'e "amal manad wa nam nek."

EASTwICK.

Bostan of S'adi.

"Grief and gladness remain not; but the recompense of virtuous deeds and the memorial of a good name, - they remain." (FALCONER).

"Ghani gar na bashi makun "iztirab

Ki sultan na khwahad khiraj az kharab."

Pandnana of S'Adi.

"If thou art not rich, be not disturbed,

Since the king will not exact tribute from the desolate."

" Ghanimat dan wa mai khur dar gulistan

Gladwin.

Ki gul ta hafta' $\theta$ digar nabashad

Zaman-i-khush dili dar yab, dar yab,

Ki da'im dar sadaf gaubar nabashad."

HAFIZ ODE, 204 .

"Spend well thy time; drink wine within the bower

For when a week is gone, the flower is not;

snatch, snatch the hour that glads the heart so well

Fin the pearl always in the shell is not."

Bicknel.L. 
"Ghanimat shumar in girami nafas,

Ki bi murgh qimat na darad qafas;

Makun 'umr za'i b'afsus wa haif,

Ki fursat aziz ast w'alwaqt saif."

BOSTAN OF S'ADI, chap. 9.

"Keckon this precious soul gain

For the cage, birdless, has no value ;

Waste not thy life in regret and sorrow

lor opportunity is precious ; and time, a sword."

(CI.ARKE).

"Ghanira zar wa sim araish ast

Walekin bifaqar andar asaish ast."

Pandanata of S'adi.

"Gold and silver are the ornament of a rich man,

But in poverty there is rest."

(GI.ADIVIN).

" Gharaz-i-naqshist k'az ma yad manad

Ki hasti ra na mi binam baqa'e

Magar sahib dile ruze barahmat

Kunad dar kar-i-darwishan dua'e."

Gulistan, Preface.

"In short, since in no mundane thing I see

The signs impressed of perpetuity;

This picture (the Gulistan) shall my sole memorial be ;

Perhaps hereafter for this pious task

Some man of prayer for me too grace shall ask."

(EASTWICK).

" Gharibe garat mast pish award,

Do paimana abast wa ek chumcha dugh ;

Gar az banda laghwi shunidi, maranj,

Jahan dida bisyar guyad darugh."

Gulistan, chap. I.

"Curds, which to thee a poor man brings, will prove

Water, two cups; and buttermilk, one spoon.

Let not my idle tales thine anger move

For, from a traveller lies thou'lt hear full soon."

(EASTWICK).

" Gharq gashta aqlhae chun jabal,

Dar bahar wahm wa girdab khiyal ;

Kuhara hast z'in tufan fazuh,

Ku amanl juz ki dar kishti Nuh;

Z'in khiyal rahzan rahi 'lyaqin

Gasht haftad wa du millat z'ahl-i-din.

Mard u'lyaqin rast az wahm wa khiyal

Mui abrura na miguyad hilal."

Jalaluddin Rumi. 
" Human reason is drowned like the high mountains In the flood of illusion and vain imaginations. The very mountains are overwhelmed by this flood, Where is safety to be found save in Noah's ark? By illusions that plunder the road of faith The faithful have been split into seventy-two sects; But the man of conviction escapes illusion, He does not mistake his eye-brow for the new moon."

(WHINFIELD).

"Ghawwas gar andisha kunad kam-i-nihang.

Hargiz na kunad durr-i-giran maya bachang." Gulistan, chap. 3.

"At the ravening monster's jaw should the diver pause and gasp He'd ne'er hold the precious pearl, the bright pearl in his grasp."

(EASTWICK).

"Ghawwas-i-tura juz gil-i-shuraba na dadast, Zira ki na didast az tu juz ki mu'ada ; Ma'na talab az zahir-i-tanzil chu mardam Khursand ma shu hamchu khar az qaul bawa." NAstR-I-KHt sRaw.

"A handful of sait-stained clay hath the diver offered to thee, Because in thy heart he beheld but envy and enmity; Strive from the Outward Form from the Inward Sense to win Like a man, nor rest content like an ass with a senseless din."

E. G. BRowne.

" Ghazab az shu'alaha'e Shaitanast, Aqibat mujib pashiman'ast."

ANivar-I-SuHeili.

"Wrath is a flame from Satan that proceeds And in the end it to repentance leads." EAstwick.

Ghazab chun nafs-i-tausin ra kunad garm, "Inanash wa kash anja ta shawad narm."

ANWAR-I-SUHEILI.

"When hot the champings of thy spirit wax Pull back the reins until thy fury slacks." EAsTilick.

" Ghudhita bidarrina wa nash'ata fina

Faman ambaka annaka ibnu dhi'bi?

Idha kana 'ttiba'a su'an

Falaitha binaf'in adabu 'ladibi."

Gulistan, chap. $\mathbf{x}$.

"Thou hast been nourished with our milk and grown up among us ;

Who informed thee then that thou art a wolf's whelp?

When the nature is a nature of evil,

Naught will the instruction of the teacher avail."

Platts.

" Ghurub shams wa qamarra chira ziyan bashad?

Tura ghurub numayad, wali shuruq buwad,

Lahad chu habs numayad, khalas-i-jan bashad."

Diwan-I-Shamis-I-TABRiz. 
"Why should setting be injurious to the sun and moon?

To thee it seems a setting, but 'tis a rising ;

Tho' the vault seems a prison, 'tis the release of the soul."

" Ghussa ma khur z'an ki shiqawat dar u'st,

(Nicholsoñ).

Khashm faru khur ki halawat dar u'st ;

Sh'asha'e barq dar azurdan ast,

Qaida'e bahr faru khurdan ast ;

Sina'e darya na shawad pur ghubar

Garchi ki baran kunadash sangsar."

ANWAR-1-SuHEILI.

"Be not thou wroth for wroth doth grief contain

Swallow thy rage and 'twill be sweet to thec

The lightning flashes but to give men pain

But as'e to swallow is thy wont, $O$ sea,

And hence thy breast is ne'er with dust o'erspread,

Though showers descend all stone-like on thy head."

"Gile khushbue dar hammam ruze

EASTWICK.

Rasid az dast-i-mahbube ba dastam ;

Badu guftam ki mushki ya ambire,

$\mathrm{Ki}$ az bu'e dilawiz-i-tu mastam.

Bagufta 'Man gil-i-nachiz budam,

Wa lekin muddate ba gul nishastam.'

Kamal-1-hamnishin dar man asr kard,

Wagarna man haman khakam ki hastam." Gulistan (Preface).

"T 'Twas in the bath, a piece of perfumed clay

Came from my loved one's hands to mine one day ;

'Art thou then musk or ambergris?' I said,

'That by thy scent my soul is ravished?'

'Not so' it answered, ' worthless earth was I,

But long I kept the ruse's company.'

Thus near, its perfect fragrance to me came

Else I'm but earth, the worthless and the same."

" Giraya kun ta badihan khandan shawi

(EAstwick).

Kin tazarra 'ra bar haqq qadraha'st

Wa an baha k'anja'st zarira kujast

Ey khusha chashme ki an giriyan-1-u'st

Wa ey humayun dil ki an buriyan-i-ust

Akhir har giraya'e ma khanda ast

Mard-i-akhir bin mubarak banda ast."

Jalaludin Rumi.

"Weep that at length thou may'st be of a smiling countenance,

For this lamentation hath great value with God;

And the value which sorrow hath there, where else has it such?

Happy the eye that thus weeps,

Noble the heart that thus burns,

In the end all our weeping shall be turned to smiles,

The man who considers the end is a blessed servant."

KeENR. 
"Gui "arche khauf hirman ast pish, Hast andar kahiii an khauf bish ; Hast dar kush ummidam beshtar Daram andar kahili afzun khatar' Pas chara dar din, ey bad-guman, Damanat migirad an khauf ziyan? Ya na didi kahil in bazarha Dar chi sudand ambiya wa auliya?"

Jalaluddin Rumi.

"You say 'Although the fear of loss is before me, Yet I feel greater fear in remaining idle.

I have a better hope through exerting myself My fear is increased by remaining idle.'

Why then, $\mathrm{O}$ faint-hearted one in the matter of religion, Are you paralysed by the fear of loss?

See you not how the traders in this market of ours

Make large profits, both apostles and saints?" WHINFIELD.

" Gui mara ki 'gauhar divan za atish ast,

Divan in zaman hama az gil mukhammarand." NASIR-I-KHUSRAw.

"Thou sayest to me "The essence of the devils is of fire; the devils of this age are fashioned from clay."

E. G. BROWNE.

" Gush dar, ey ahwal inha ra ba hush

Daru'e dida bikash az rah-i-gush

Bas kalam pak dar dilha'e kur,

Minayad, mi rawad ta asi-i-nur ;

W'an afsun div dar dilhae kajh,

Mirawad chun kafash kajh dar pae kajh."

JAlAluddin RUm.

" $\mathrm{O}$ man of double vision, hearken with attention, Seek a cure for your defective sight by listening Many are the holy words that find no entrance Into blind hearts but they enter hearts full of light. But the deceits of Satan enter crooked hearts Even as crooked shoes fit crooked feet."

WHINFIEI.D.

"Gush-i-tu du dadand zaban-i-tu yake

Y'ane ki du bishnu, wa yake pish magu."

HAFIZ.

" Two years and but a single tongue

By nature's law to nian belong;

The lesson she would teach is clear,

'Repeat but half of what you hear.',

(Asiatic Journal.).

"Gush kun az man in nukta'e khush

Ki manad ast dar gusham az nukta danan,

Ki har k'u kashad tigh-i-na-mihrbani

Shawad kushta'e tigh-i-na-mihrbanan." Jami, Biharistan, chap. 2. 
"Lea n this good saying which I heard from those wluo know wise saws:

"Who draws the unrighteous sword, will be slain ly the sword of the unrighteous."

(REHATSEK).

" Gush tawanad ki hama umr wai

Nashnawad awaz-i-daf wa chang wa nai ;

Dida shikibad za tamasha'e bagh,

Bi gui wa nasrin basar ayad dimagh ;

Gar na buwad balish agandah par

Khwab tawan kard hajar zir-i-sar;

Wa in shikam bi-hunar pich pich,

Sabr na darad ki basazad ba hich."

Gulistan, chap. 3 .

"The ear may never through one's life

Hear sound of tabor, lute, or fife,

The eye abstain from floral show

The brain the rose's scent not know :

Though pillowed not on down, the head

May on a stone find sleep instead,

But this vile belly base and dull

Will never rest until its full."

(EASTWICK).

" Guyand 'ishq chist,' bigu 'tark-i-ikhtiyar'

Har k'u za ikhtiyar narast, ikhtiyar nest." Diwan-I-Shams-I-TABriz.

"They say 'What is lore?" Say 'renunciation of will'

Whoso has not escaped from will, no will has he."

(Nicholson).

"Gufta ii kist bar dar, guftam kamin ghulamat;

Gufta che kar dari, guftam miha salamat ;

Gufta ki chand rani, guftam ki ta bikhwani ;

Gufta ki chand jushi, guftam ki ta qiyamat."

DIw AN-I-SHAMS-1-T ABR1Z.

"He said 'Who is at the door?' Said I "Thy humble servant.'

He said 'What business have you ?' Said I 'Lord, to greet thee.'

He said 'How long will you push?' Said I 'Till thou call.'

He said 'How long will you glow ?' Said I 'Till resurrection."

(NICHOLSON).

" Guftam ki dila mubarakat bad

Dar halqa'e ashiqan rasidan,

Z'an sue nazar nazara kardan

Dar kucha'e sinaha duwidan."

Diwan-I-Shams-I-T Abrit.

" ' Oh heart,' said I, ' may it bless thee

To have entered the circle of lovers,

To look beyond the range of the eye

To penetrate the windings of the bosom."

(Nicholson). 
" Guft an nasih nikhwah

Bigush-1-dil an sitamgarah shah, Ki az zulmat-i-zulm andisha kun, . Pai azmun 'adl ra pisha kun, Agar adalat az zulm niayad farih, Digar barah dar rah-i-zulm nih."

"Well did that kind adviser say

To the heart of a tyrannic king :

'Be on thy guard of the darkness of tyranny, Practise justice for an experiment, If justice does not pay better than tyranny Thou naayest again oppression try."

(REHATSEK).

" Guftan az zambur bi hasil buwad

Ba yake dar umr-i-khud na khurda nish;

Ta tura hale nabashad hamchu man

Hal-i-ma bashad tura afsana pish ;

Suz-i-man ba digare nisbat ma kun,

U namak bar dast bar dast wa man ba "uzu rish."

Gulistan, chap. 5.

" Of the hornet's wound

What reck they who did never feel

Its sting. Till fortune shall bring round

Thy woes to thee, they will but seem

The weak illusions of a dream.

Do not my sufferings confound

With those of others. Canst thou deem

One holding salt can tell the pain of him

Who has salt rubbed upon his wounded limb?"

EAS'TwICK.

"Guft 'Atfal manand in auliya,

Dar gharibe fard az kar wa kiya;

Az barae imtihan khwar wa yatim,

Lekin andar sar manam ba u nadim ;

Pishat dar jumla 'asmatha'e man,

Guya hastand khud ajza'e man."

Jalaluddin Rum.

" He saith "These saints are My children

Though remote and alone and away from their Lord.

For their trial they are orphans and wretched

Yet in love I am ever holding communion with them.

Thou art backed by all My protection,

My children are as it were parts of Me."

(WhiNfIELD). 
" Guft ba Daud paighambar khuda'e,

Kamat khudra bigu ey nik rae

Gar 'A Jam chun badshahan awarand,

Nam ishan juz ba nlki kam barand ;

Garchi bud atish-parasti din ishan

Bud 'adl wa rast1 ishan

Qarnaha za ishan jahan m'amur bud

Zulmat-1-zulm az raiya dur bud.

Bandagan farigh za gham farsudagi

Dashtand az adl ishan sudagi."

Jami (Salainan and Absai.).

" God said to the Prophet Davirl

'David, speak, and to the challenge

Answer of the faith within thee.

Even unbelieving princes

Ill-reported if unworthy

Yet, if they be just and righteous,

Were their worship of the fire,

Even these unto themselves

Reap glory and redress the world."

(E. FITZGERALL).

" Guft dar gush-1-gul wa khandanash kard,

Guft ba sang wa 'aqiq-i-kanish kard.

Guft bajism ayate ta jan shud $u$

Guft ba khurshid ta rukhshan shud $u$,

Baz dar gushash damad nukta makhauf

Dar rukh khurshid uftad sad kasuf."

JaLALCDDin Rum.

"He speaks to the rose's ear and causes it to bloom, (He speaks to the stone and it becomes a jewel of the $m$ ine), II speaks a spell to body and it becomes soul, IIe speaks to the sun and it becomes a fount of light Again in its ear IIe whispers a word of power And its face is darkened as by a hundred eclipses."

(WHINFIELD).

\footnotetext{
"Guft "ey yaran haqqam ilham dad

Bar zaiflra qawi rai uftad

Anchi haqq amukht mar zambur ra

An na bashad sher ra wa gur ra

Khanaha sazad pur az halwa tar

Haqq bar $u$ an ilmra bikushad dar,

Anchi haqq amukht kirm pilare

Hich pili danad an gun hila ra."
}

Jalaludis Rum. 
" He said ' $\mathrm{O}$ friends, ( od has given me inspiration Oftentimes strong counsel is suggested to the weak. The wit taught by God to the bee Is withheld from the lion and the wild ass. It fills its cells with liquid sweets, For God opens the door of this knowledge to it. The skill taught by God to the silkworm Is a learning beyond the reach of the elephant."

(WHINFIELD).

" Guft-i-alim ba gush-i-jan bishnau

War namanad ba guftanash kardar, Batilast an ki mudd'ai guyad

Khuftara khufta kai kunad bedar?

Mard bayad ki girad andar gush

War nawishtast pand bar diwar."

Gulistan, chap. 2.

" Heed thou well the wise man's warning Though his acts his words belie;

Futile is the objector's scorning 'Sleepers ope not slumber's eye.'

Heed then well the words of warning Though on a wall thou them descry."

(EAstwick).

" Guft Laile ra khalifa k'an tu'i

K'az tu Majnun shud parishan wa ghawi?

Az digar khuban tu afzun nesti

Guft khamush chun tu Majnun nesti,

Dida'e Majnun agar budi tu-ra,

Har du 'alam be khatar budi tu-ra."

Jal,aluddin RUmi.

" The khalifa said to Laila 'Art thou really she

For whom Majnun lost his head and went distracted?

Thou art not fairer than many other fair ones.'

She replied, 'Be silent ; thou art not Majnun!

If thou hadst Majnun's eyes,

The two world's would be within thy view."

WHINFIELD.

" Guft paighambar 'Ali ra 'k'al All

Sher haqqi pahlawani pur dili,

Lek bar sheri makun ham itimid

Andar aur saya-e-nakhl ummid

Andar aur saya-e-an aqile

Kas natanad burd az rah naqile

Zill-i-u andar zamin chun kuh-i-Qaf,

Ruh-i-u Simurgh bas ala tawaf

Gar baguyam ta qiyamat n'at-i-u

Hich anra muqatt'a wa ghayat ma ju

Dar bashar rupush gardast aftab.

Fahm kun wa Allah alim bi' sawab." "

Jalaluddin RUM. 
"The Prophet said to Ali 'O Mli

Thou art the Lion of God, a heru most valiant;

Yet confide not in thy lion-like valnur

But seek refuge under the palm-trees of the truth

Come under the shadow of the Man of Reason,

Thou canst not find it in the road of the traditionists.

His shadow on earth is as that of Mount Qaf,

His spirit is as a Simurgh soaring on high.

Were I to tell his praises till the last day

My words would not be too many nor admit of curtailment ;

That sun is hioden in the form of a man

Uunderstand me. Allah knows the truth."

(WHINFIELD).

" Guft paighambar ki Haqq farmuda ast

Man na ganjam hich dar bala wa past

Dar zamin wa asman wa 'arsh niz

Man na ganjam, in yaqin dan, ey 'azjz;

Dar dil-i-mumin biganjam, ey 'ajab,

Gar mara ju'i, dar an dilha talab."

Jalallidin Rum,

"The Prophet said that God has declared,

- I am nut contained in aught above or below,

I am not contained in earth or sky or even

In highest heaven, know this for a surety, $O$ beloved,

Yet am I contained in the believer's heart,

If ye seek Me, search in such hearts."

WHINFIELD.

“ Gul ni'mati'st hidaya flristada az bihisht.

Mardum karimtar shavad andar naim-i-gul,

Ey gul-furush $\mid$ gul chi flrushi barayi sim

W'az gul aziztar chi sitani bi-sim-i-gul."

KISA'r.

"A heaven-sent gift and blessing is the rose

Its grace inspireth aspirations high

Oh flower girl, why the rose for silver sell?

Or what more precious with its price can buy?

E. G. Browne.

" Gul raft za bagh khar wa khas ra chi kunam?

Shah nest bashahr, dar asas ra chi kunam?

Khuban qafsand, husn wa khubi tote,

Tote chu parid, qafs ra chi kunam?"

Jami, Bimaristan, chap. 5.

"The rose has left the garden, of what use are the thorns?

The shaw is not in the town, of what use is his retinue?

Belles are the cage, beauty and attraction the parrot,

When the parrot has fled, of what use is the cage?"

REHATSEK.

"Gurgi wa sagi kam kun ta mihr-i-shaban bini."

Diwan-I-Shans-I-Tabriz. 
"Cease to behave as wolves and dogs that you may experience the Shepherd's love."

(NICHOLSON).

"Guzar gah koran wa pandast gush

Bi buhtan wa batil shunidan makush." Bostan of S'ADI, chap. 8.

"The ear is the thoroughfare for the Koran and counsel

Strive not to listen to calumny and falsehood." (Cl.ARKE).

" Habatat 'ilaika mina 'Imahalli 'larfa"

Waraqau dhatu taazzuzin wa tamannu'i

Mahjubatun 'an kulli muqlati 'arifln

Wa hia 'llati safarat wa lam tatabarq'a.

Wasalat 'ala kurhin ilaika wa rubbama

Karihat firaqaka wa hia dhatu tafajju'i."

Avicenna,

"It (the soul) descended upon thee from the lofty station, a dove rare and uncaptured, curtained from the eyes of every creature; yet 'tis it which is manifest and never wore a veil. It came to thee unwillingly and it may perhaps be unwilling, althuugh it complain of its sufferings, to leave thee."

De Si.ane.

" Hadis-i-dust naguyam magar bahazrat-i-dust Ki ashna sukhan-i-ashna nigah darad."

HAFIZ, ODE, 146.

" News of a friend but to a friend I tell

The bosom's thoughts the bosorn's friend keeps well."

Bicknel.t.

" Hafldh 'ala taqwa 'llahi wa khaufli

Litanjua mimma yuttaqa min iqabihi

Wa la talhu 'an tadhkari dhumbik, w'abkihi

Bidam in yudhahi 'lwabla hala masabihi"

" Keep to the fear of God and the dread of Him that thou may'st escape from His punishment which is to be feared.

Neglect not, call to mind thy sin, but weep for it with tears that shall be like the rain-flood at its pouring."

(Cheneky).

" Haflz madar ummid-i-farah z'in madar-i-kaun, Darad hazar "aib wa na darad tafazzuli."

Hafiz, Ode 528.

"From life's home, O Hafiz, what joy can be won?

Defects it has thousands, but excellence none." Bicknert.

"Haif ast ki dar zumra mardan bashad nam

An ra ki haqq-i-suhbat-i-yaran nashinasad." ANwar-l-SuheIL.I.

" One who is blind to friendship's rights, 'twere shame

To mention in the rank of men his name." EAsTwICk. 
" Hakimera kard shagirde suwal

K 'ey munhadis kist farzand halai?'

Guft 'k'an k'u 'aqibat gardad shabih

Ba pidar, gar ba khirad ast wa gar safih ;

Chand ruze gar na manad ba pidar,

Aqibat khudra rasanad ba pidar."

Jami, Salaman and Absal.

" A disciple asked a master

'By what token should a father

Vouch for his reputed son?'

Said the Master 'By the stripling

Ilowsoever late or early,

Like to the reputed father,

Growing, whether wise or foolish."'

E. Fitzgerald,

" Hakim guft ki taqdir sabiq ast, wale

Bahich hal tu tadbir-i-khud faru magzar ;

Ki gar muwaflq hukm-i-qazast tadbirat

Ba kam-i-dil shawi, az kar-i-khwish barkhurdar."

ANWAR-1-SUHEILI.

“" True' said the wise man 'fate preceeds, but still

Neglect in no case thine own plans for should

Thy counsels coincide with the high will

Of destiny then thine own actions would secure thee fruit to thy heart's wish." "

(EASTWICK).

"Hal nunabbi 'ukum bi'l 'akhsarina 'a'malan 'alladhina dhalla sa'iuhum fl'halyatl' dduniya wa hum yahsabuna 'annahum yuhsinuna sun'an, aula'ika kafaru bi'ayati rabbihim wa liqa'ihi."

KORAN, chap. 18.

"Stall we tell you who they are that have lost their labour most? Whose aim in the present life hath been mistaken, and that deem that what they do is right? They are those who believe not in the signs of the Lord or that they shall ever meet Him."

(RODWELL).

"Halaka 'nnasu haulahu 'atashan

Wa huwa saqin yara wa la yasqi."

Gulistan, chap. 2.

"Men perished around him of thirst

And he was a cup-bearer who saw and would not give to drink."

(PlatTS).

"Hama yar-i-tu az bahr tarashand

Pae luqma hawadar-i-tu bashand;

Chu malat kahad az mihr-i-tu kahand

Zlyanat bahri sud-i-khwish khwahand;

Az in mushti rafligan riyai

Buridan bihtar ast az ashnaf."

ANwar-1-Suheill. 
" Thy friends are all on parings set

Each loves thee for what he can get;

As thy wealth fails thee, love grows less

For their own ends thy fall they'd bless;

From such a band of false allies

To part, nor call them friends, were wise."

"Ham chunan dar flkr-i-an baitam ki guft

EAstwick. Pilbani bar lab-i-darya'e Nil ;

Zir-i-payat gar badani hal-i-mur, Hamchu hal-i-tust zir-i-pa'e pil."

" Just thus that couplet I recall, which said

On the Nile's bank he of the elephant:

'Wouldst thou know what the ant feels neath thy tread

Think if on thee my beast its foot should plant !"

" Hamchu sange k'u shawad kul l'al nab,

Pur shawad u az sifat-i-aftab;

Wasf an sangi na manad andar $u$

Pur shawad az wasf-i-khur u pusht ru."

JALALUdDin RUMr.

"As a stone which is changed into a pure ruby

Is filled with the bright light of the sun,

In that stone its own properties abide not

It is filled with the sun's properties altogether."

"Ham khuda khwahi, ham dunya dun,

In muhal ast, in khiyal ast, in junun."

Jalaluddin Rumi.

"You wish to have both God and the base world together,

This is impossible, ridiculous and mad."

"Hangam-i-sabuh ey sanam-i-farrukh pai

Bar saz taranae wa pish awar mai,

K'afgand bakhak sad hazaran Jam wa Kai

In amadan-i-Tir mah wa raftan Dai."

OMar Khayyam.

"Angel of joyful foot ! the dawn is nigh

Pour wine and lift thy tuneful voice on high,

Sing how Jamsheds and Khosraus bit the dust

Whelmed by the rolling months from Tir to Dai."

" Haqq flristad ambiyara bahri in

(WhinfiRLD).

Ta juda gardad za ishan kufr wa din;

Mumin wa kafir, Mussalman wa Jahud

Plsh az ishan jumla yaksan namud."

Jalaluddin Rumi.

" God sent the prophets for this purpose

Namely to sever infidelity from faith,

Infidel and faithful, Mussalman and Jew,

Before the prophets came, seemed all as one." WHiNfield. 
" Haramash buwad n'imat-i-badshah

Ki hangam-i-fursat na darad qarar;

Majal-1-sukhan ta nabini za pesh

Ba behuda guftan mabar qadr-1-khwish."

Gulistan, chap. $:$.

"Let him not hope kings' favours who omits

To watch the moment which his prayer befits.

Till thou observest the just time for speech

Do not by useless words thy cause impeach."

(EASTwICK).

"Haram dar pishat wa harami dar pas; agar rafti burdi, agar khufti, murdi."

Guzistan, chap. 2.

"The sanctuary is before thee, and the robber behind: if thou goest on thou wilt obtain thy object ; if thou sleepest, thou wilt die."

EASTWICK.

" Har an dushman ki ba way ahsan kunl dust gardad magar nafs ki chandan ki madara blsh kuni mukhalifat ziyadat kunad."

(Gulistan, chap. i).

"Every enemy on whom thou conferrest favours becomes a friend save lust, whose hostility increases the more thou dost gratify it."

(EAsTwick).

"Har an kas ki dar band-1-hirs uftad

Dihad khirman zindagani babad."

Pandiama of S'adt.

"Whosoever falleth into the prison of avarice

Giveth the harvest of life to the winds."

Gladwis.

" Har anki tukhm-i-badi kisht wa chashm-i-niki dasht

Dimagh behuda pukht wa khiyal-i-batil bast;

Za gush pumba birun ar wa dad-i-khalq bidih,

Wa gar tu mina dihi dad, ruz-i-dadi hast."

Gulistan, chap. x.

" Who sows ill actions and of blessing dreams

Fosters vain phantasies and idly schemes;

Unstop thy ears, thy people's wants relieve

If not, a day shall come when all their rights receive."

(EASTWICK).

"Hal atish ki dast-l-qaza bar farukht

Hama fikr wa tadbirhara basukht."

ANWAR-I-SUHEILI.

"When fate's hand the mighty flame has lit, All thought, all counsel is consumed in it."

Eastwick.

" Har bala'e k'az asman ayad

Garchi badigare qaza bashad

Bazamin narasida mi-guyad

Khana'e Anwari kuja bashad."

(ANWAK1). 
"No sooner does any calamity coming from the sky reach the ground, than it asks, although it be destined for someone else, "Where is the house of Anwari?"

(KUKA).

"Har chand ki rang wa bu-e-zebast mara Chun lala rukh wa chu sar wa balast mara M'alum nashud ki dar tarabkhana-e-khak Naqqash-i-man az bahr-i-chi arast mara."

Omar Khayyam.

"What though 'tis fair to view, this form of man

I know not why the heavenly Artisan

Hath set these tulip cheeks and cypress forms To deck the mournful walls of earth's divan."

WHINFIELD.

" Har char unsur and dar in digh ham bajush

Na khak bar qarar wa na nar wa nam wa hawa;

Gah khak dar libas-i-giya rafta az hawas;

Gah ab khud hawa shuda az bahr-i-in wala

Az rah-i-ittihad shuda ab atishi

Atish shuda za'ishq hawa ham dar in faza."

Diwan-1-Shans-I.T AbRIZ.

"All the four elements are seething in this cauldron (the world)

None is at rest, neither earth nor fire nor water nor air

Now earth takes the form of grass on account of desire

Now water becomes air for the sake of this affinity,

By way of unity water becomes fire

Fire also becomes air in this expanse by reason of love."

(Nicholson).

"Har chi girad 'illate illat shawad, Kufr girad kamil, millat shawad."

JaLALUDDIN RUMu.

"Whatever a sick man eats is a source of sickness;

But if a saint imbibe infidelity, it becomes faith."

WHINFIELD.

"Har chi za ghaib ast be'aib ast."

Persian Proyerb.

"What the Unseen sends us cannot have defect."

(Eastwick).

" Har dam az 'umr mirawad nafsi

Chun nigah mikunam, namanad basi ;

Ey ki panjah raft wa dar khabi,

Magar in panj ruz daryabi."

Gulistan, (Preface).

" One breath of life each moment flies

A small remainder meets my eyes.

Sleeper! whose fifty years are gone

Be these five days at least thine own." (Eastwick). 
" Har dil ki dar u nur-i-muhabbat basarisht

Gar sakin-i-musjid ast wa gar za ahl-i-kanisht

Dar daftar-1-ishq har ki ra nam nawlsht

Azad az duzakh ast wa farigh za bihisht."

OMAR KHAYYam.

" Hearts with the light of love illumined well

Whether in mosque or synagogue they dwell, Have their names written in the book of love Unvexed by hopes of heaven or fears of hell."

" Har du gun zambur khurdand az mahal

(WIINFIELD).

Lek shud z'in nish z'an digar 'asal

Har du gun ahu giya khurdand wa ab

Z'in yake sargin shud, wa z'an mushk nab,

Har du nai khurdand az ek abkhur

In yake khali wa an pur az shakar."

JALALUdDin RUMi.

" Both sorts of bee (i.e. bee and wasp) draw nourishment from one place but from this comes the sting and from that other the honey.

Both sort of deer feed on the same grass and water; by this only dung is produced, by that pure musk.

Both reeds (the common reed and the sugar-cane) are fed from one source ; this one is hollow, while that one is full of sugar."

\section{E. G. BROWNE.}

" Hargiz na mirad an ki dilash zinda shud ba ishq

Sabatast bar jarida'e 'alam dawam-i-ma."

HAFI2 ODE, 3.

" He whose soul by love is quickened never can to death be hurled, Written is my life immortal in the records of the world."

" Har ki aib-i-digaran pish-1-tu aurad wa shumard,

(BICKNELL). Bi-guman aib-i-tu pish-i-digaran khwahad burd."

Gul.istan, chap. 2.

"They who the faults of others bring to you

Be sure they'll bear to others your faults too."

" Har ki ain-i-zulm pish nihad

(EASTWIICK).

Band ba dast wa pa'e khwish nihad;

Chend ruze agar sar afrazed

Dahrash akhir za pa dar andazad."

ANWar-1-Suhril.t.

"They who have chosen an unjust career

Do gyves on their own hands and feet impose

What though they should some days their heads uprear

Yet fortune in the end all such o'erthrows."

EASTWICK.

" Har ki amad imarat-i-nau sakht

Raft wa manzil badigari pardakht

Wa an digar pukht hamchunin hawase

Wa in imarat basar naburd kase."

Gulistan (Preface). 
"Each comer a new house erects

Departs, - the house its lord rejects.

The next one forms the same conceit

This mansion none shall ere complete." (EAsTwick).

" Har ki asudagi wa rahat just
Dil khud ra za bakht shad na kard ;
Wa anki tarsid az jafa'e khamar
Qadah bada'e murad nakhurd."

" Those easy souls who venture nought

Ne'er their hearts gladden with success

Who fear the revel's after-thought

With vinous aches and throbbings fraught

Ne'er drain the bowl of happiness."
ANWAR-1-SUHBIL.1.

EASTwick.

" Har ki ba pulad bazu panja kard

Ba'id-i-simin-i-khuđra ranja kard ;

Bash ta dastash babandad ruzgar

Pas bakam-i-dustan maghzash birar."

Gulistan, chap. $x$.

" $\mathrm{He}$ that has grappled with a hand of steel

Will in his silver arm the anguish feel ;

Wait thou till fortune shall his hand rcstrain

Then at thy will, thou mayest thy foeman brain."

" Har.ki dar asl bad nihad uftad

(EASTWICK).

Hich neki az u madar ummed,

Z'anki hargiz ba jihad natawan sakht

As kalaghsiyah baz sufld."

ANWAR-I.SUhetL.

" Expect no trace of goodness in the man

Who from the outset is by nature bad,

For by no efforts of thy making can

A white hawk from a dingy crow be had."

EASTIVICK.

“ Har ki faryad-ras-i-ruz-i-musibat khwahad,

Gu dar ayyam-i-salamat bi jawanmardi kush;

Bandae khalqa ba gush ar nanawazi birawad

Lutf kun, lutf ki big'anah shawad khalqa ba gush."

Gulistan, chap. $x$.

"He who in adversity would succour have

Let him be generous while he rests secure.

Thou that reward'st him not, wilt lose thy slave

Though wearing now thy ring. ${ }^{*}$ Wouldst thou secure

The stranger as thy slave, to him be kind

And by thy courtesy enslave his mind."

EAstwick.

* The ring in the ear is the badge of servitude in the East. 
- Har ki 'ilm shud ba sakha wa karm Band nashayad ki nihad bar daram Nam-1-nekui chu birun shud bikul Dar natawani ki bi bandi biruf."

" Whom mankind with the name of 'generous' grace Must on his dirhems no restrictions place ; When our good fame pervades the public street, We must no suitor with denial meet."

EASTIVICK.

" Har ki iman tura kandan wa paiwastan guft

Bayad an qaul pasandtda az u bipasandi; Hasil m'ana an kandan wa paiwastan chist?

Yane az khalq kani dłl, bakhuda paiwandi."

Jami, Beharistan, chap. I.

"Whoever told thee that faith is 'to dig up and unite,"

Thou must approve of his laudable definition.

What is the meaning of to upront and to join?

It is to sever thy heart from creatures, and unite it to the Creator."

REHATSEK.

" Har ki mazrui-i-khud khurad bi khawid,

Waqt-i-kirmanash khusha bayad chid

Pand-i-Saadi ba gush-i-dil bishnau

Rah chunin ast, mard bash, wa birau."

Gulistan, Preface.

"Who eat their corn while yet 'tis green, At the true harvest can but glean.

To Saadi's counsel let thy soul give heed,

This is the way, be manful and proceed." (EASTwick).

"Har kira bashad za sina fath bab

U za har zarra bibinad aftab."

JALALUddin Rumi.

" He, the door of whose breast has been opened, sees the sun reflected in every atom."

" Har kira jama parsa bini

Parsa dan wa nik mard angar;

War nadani ki dar nihanash chist

Muhtasibra darun-l-khana chi kar?"

Gulistan, chap. 2.

"When thou dost one in saintly vestments find

Doubt not his goudness or his sanctity.

What though thou knowest not his inmost mind

Not within doors need the policeman pry." (EASTwICK).

" Har kira jah wa daulatast wa badan

Khatir khasta dar nakhwahad yaft;

Khabarash dih kl hich daulat wa jah

Basara'e digar nakhwahad yaft."

Gulistan, chap. 8. 
"Tell those to whom rank, wealth are given

Who care not for the sons of pain, That in the bright abodes of heaven

Thcy neither wealth nor rank will gain." EASTwick.

“ Har ki ra khwabgah akhir bada mushti khakast, Gu 'chi hajat ki bar aflak kashi aiwan ra?'”

HAFIZ ODE, 7.

" As earth, two handfuls yielding, shall thy last couch supply, What need to build thy palace aspiring to the sky." BICKNELL.

"Har ki tigh-i-sitam kashad birun Falakash ham badan birizad khun."

ANwar-I-SUheILI.

"Whoever dares unsheathe the tyrant's sword Blood will for that froin heaven on him be poured."

Eastwick.

" Har muhal az dast-i-u mumkin shawad

Har harun az bim-i-u sakin shawad.

Akma wa abras chi bashad murda niz,

Zinda gardad za afsun-i-an aziz.

Kamtarin karash bahar ruz an buad

K'u sih lashkar ra rawana mikunad,"

JaLALUddin Rumi.

"Impossibities are possible to Him,

The stubbornest is docile when His will curbs whim,

The blind from birth, the leper, e'en the dead arise

Whole, sound, whene'er the Omnipotent 'Come forth !' but cries.

His smallest daily toil, a work-like pleasure still,

Is to send forth three armies, bound to work His will."

(REDHOUSE).

"Har nafas awaz-i-ishq mirasad az chap wa rast

Ma ba falak mi-rawem 'azm-i-tamasha kirast."

Diwan-1-Shams-1-Tabriz.

" Every moment the voice of Love is coming from left and right

We are bound for heaven; who has a mind to sight-seeing?"

(NICHOLSON).

"Har naqshra ki didi jinsash za lamakanast, Gar naqsh raft gham nest, aslash chu jawidanast, Har surate ki didi, har nuqta ki shunidi, Bad-dil mashu ki raft zira na an chunanast."

Diwan-I-Shams-I-TABRiz.

"Every form you see has its archetype in the placeless world,

If the form perished, no matter, since its original is everlasting, Every fair shape you have seen, every deep saying you have heard, Be not cast down that it perished, for that is not so."

(NiCHOLSON). 
" Har nuqta k'ayad az lab wa dandan chu gauhar ist

Khush an ki sakht ganj-l-gauhar darj sina ra." JAMI, BIHARISTAN.

" Every maxim uttered by the mouth and teeth is a jewel, Happy is he who has made of his breast a casket of jewels."

ReHATSEK.

" Har zarra kl dar ru-e-zamini buzast

Khur shezarkhi zuhra jabini buzast

Gard az rukh-i-naznin bazaram fishan

K'an ham rukh wa zulf-i-naznini buzast." OMar KнаYYaM.

" Each grain of dust that on the ground is shed

Was once a Venus brow or sunny head,

Blow the dust gently from thy cheek fair maid

'Twas once a curl whose owner now lies dead."

WIIINFIELD.

"Hasil-i-kargah kaun wa makan, in hama nist

Bada pish ar, ki asbab-i-jahan, in hama nist,

Az dil wa jan sharf-1-suhbat-i-janan gharzast

Hama anast; wagarna dil wa jan in hama nest." HAFIz ODE, 88.

"The profits of earth's labouring place as nothing are,

Bring wine! the things of time and space as nothing are.

Love's converse high is heart and spirit's goal,

Yea, all is this ; else heart and soul as nothing are."

BICKNELL.

" Hasil na shawad riza-i-Sultan

Ta khatir-i-bandagan na jui,

Khwahi ki khuda bar tu bakshad

Ba khalq-i-khuda kun nikul."

Gulistan, chap. I.

"The Sultan's praise thou can'st not gain

Till thou can'st win his people's heart, Wouldst thou God's pardoning grace obtain

Then to his creatures good impart."

(EAST WICK).

"Hast bar mardum ala gauhar

Bukhul za asraf pasandidatar."

Anivar:1-Suheill.

"Men of a noble nature less eschew

The parsimonious than the profligate." EAsTwick.

" Hawa'e nafs mahar ast wa khalq chun shuturan

Baghair-i-an shutur-1-mast-ra mahar magir."

Diwan-I-Shams-1.Tabriz.

"Sensual desire is a bridle and men are as camels

Do not suppose there is any bridle except that for the senseless camel."

(NICHOLSON). 
" Hazar bar charagah khushtar az maidan Wa lekin asp nadarad bidast-i-khwish "anan."

Gulistan, chap. 8.

" Far better is the pasture than the battle-plain

But the horse guides not for himself the rein."

EASTIVICK.

"Hazar khwish ki begana az khuda bashad

Fida'e ek tan-i-begana k'ashna bashad."

Gulistan, chap. 2.

"Thou for one friendly stranger sacrifice

A thousand kinsmen who their God despise."

“ Hazar kun za dud-i-darunha'e-rish,

(EASTWICK).

Ki rish-i-darun 'aqibat sar kunad;

Baham bar makun ta tawani, dili,

Ki ahe jahane baham bar zanad."

Gulistan, chap. $\mathbf{x}$.

"Beware of the sigh of the wounded heart,

For the secret sore you'll too late discern;

Grief, if thou canst to no bosom impart,

For the sigh of a grief will a world o'erturn."

"Hazar naqsh bararad zamana wa na bud

Yake az an chi dar aina'e tasawwar ma'st."

(EASTwick).

" Fortune in all her changes showed me nought

Such as I pictured in the glass of thought." EAsTwick.

" Hich "ashiq khud na bashad wasl-ju

K'az na mashuqash buwad juy'e u."

ANWAR-1-SUheILI.

" No lover ever seeks union with his beloved,

Without his beloved seeking him in turn."

"Hich bang-i-kaf zadan ayad badar

Az yake dast tu bi dast digar ;

Tishna mi nalid ki ku ab gawar

Ab ham nalid ki ku an ab khwar,

Jazb abist an atsh dar jan-i-ma

Ma azan u wa u azan-i-ma."

JaLALUddin Rumi.

"The noise of clapping of hands is never heard

From one of thy haxds unaided by the other hand

The man athirst cries; 'Where is delicious water?'

Water too cries 'Wherc is the water-drinker?'

This thirst in my soul is the attraction of the water

I am the water's and the water is mine." (WhINFIELD).

"Hichkas nazanad bar darakht-i-bi-b.ìr sang." Gulistan, chap. 1.

" None cast stones at trees save fruit be there."

(EASTWICK). 
"Hich kas rah sue bala na yaft,

Ta qadam az himmat wa ala na yaft;

Martabaju ki barai ba mah

Kas na khurad sharbat-1-baran ba chah."

ANwar-1-Suheill.

" None ever found the way on high to rise,

Till he obtained the step of high emprise

Seek rank, that to the moon thou mayest nount

None drink cloud-water from a well's low fount."

" Hich kas 'ukda'i az kar-1-jihan baz na kard

Har ki amad girihi chand barin tar fuzud."

EAstivick.

(ANON).

"No one yet hath unravelled a knot from the skein of the Universe, And each who came and essayed the same but made the tangle worse."

"Hich name bi haqiqat didai?

(E. G. BROWNE).

Ya za Gaf wa Lam 'gul' chidai?

Ism khwandi rau, musamma ra bi ju,

Mah ba bala dan na andar ab ju ;

Gar za nam wa harf khwahi bugzari

Pak kun khudra za khud han yaksari."

JALALUdDin Rumi.

"Know you a name without a thing answering to it?

Have you ever plucked a rose (Gul) from Gaf and Lam?

You name $H$ is name; go seek the reality named by it.

Look for the moon in heaven, not in the water.

If you desire to rise above mere names and letters

Make yourself free from self at one stroke." (WhiNfieLD).

" Hich ri 'mat bihtar az farzand nist

Juz ba jan-i-farzand ra paiwand nist ;

Hasil az farzand gardad kam-1-mard

Zinda az farzand manad nam-i-mard,

Chashm-i-tu ta zinda rushan badu'st,

Khak-i-tu chun murda gulshan badu'st

Dast-i-tu girad agar ufti za pae

Payat amba shud agar manad bajae." Jam, Salaman and Absal.

"Is any blessing better than a son?

Man's prime desire; by which his name and he

Shall live beyond himself; by whom his eyes

Shine, living and his dust with roses blows,

A foot for thee to stand on; he shall be

A hand to stop thy falling."

E. FitzGerald.

“ Hifz-i-shah bayad chunan k'az astan-i-u 'abur

Dar zamir-i-banda'e wa azad natawanad guzasht;

Dar harim hurmat Izzash kj sar-1-daulat ast

Murgh natawanad parid, wa bad natawanad guzasht."

JaMi, Biharistan. 
" The Shah is to be so guarded, that to overstep his threshold Must not enter the head of a slave or a freedman;

To the sanctuary of his honour which is the seat of dominion

No bird can fly, no wind can penetrate."

(REHATSEK).

" Hijab-i-chihra'e jan mi shawad ghubar-i-tanam

Khusha dame ki az in chihra parda bar flkanam

Chunin qafas na sazai chu man khushilhanist

Rawam bagulistan-i-Ridhwan ki murgh-i-an chamanam."

HAFIZ ODE, $3^{8} 5$.

" The dust of my corporeal frame has my spirit's features veiled,

That veil removed which hides that face, what delight shall then be hailed!

A songster of my own sweet strain ill befits this cage's tie

Fain to Rizvan's parterre I'd soar, for yon meadow's bird am I."

(BICKNELL).

" Hikmat talab wa buzurgi amuz

Ta bih gardad ruzat az ruz.".

ANIVAR-I-SUHEILl.

"Seek wisdom, study greatness that men aye May note thy morrow happier than to-day."

(EASTWICK).

" Himmat darwish chu hamrah shawad

Khwajah za asrar-i-dil agah shawad;

Har ki za ma'na khabre yaftast

Az dil sahib-i-nazare yaftast."

Anwar-I-SuheILl.

"With whom the blessings of the pious go,

He learns the secrets of the heart to know ;

Whoe'er have fathomed wisdom's mysteries

Have learned them through the teaching of the wise."

EAstwick.

"Hin bidih, ey zagh, jan wa baz bash,

Pish tabdil khuda jan-baz bash ;

Taza me gir, wa kuhan ra me sipar,

Ki har imsalat fazunast az sih bar."

JALALUDdin RUMi.

"Ah! O crow, give up this life and live anew ?

In view of God's changes cast away your life !

Choose the new, give up the old,

For each single present year is better than three past."

(WHINFIELD).

" Hin makun khud-ra khasi rahban mashu

Z'an ki iffat shahwat ra girau;

Bi hawa, nahi az hawa mumkin na bud

Ham ghaza ba murdagan natawan namud." Jalaludin Rum. 
" Ah ! make not thyself a eunuch, become not a monk, Bccause chastity is mortgaged to lust.

Without lust, denial of lust is impossible,

No man can display bravery against the dead." WHINFIELD.

" Hin subh damid wa daman-i-shab shud chak

Barkhiz wa sabuh kun chira'i ghamnak.

Mi-nush, dila, ki subh bisyar damad

U rue ba ma karda wa ma rue bakhak."

Omak Kuavyam.

"See! the dawn breaks and rends night's canopy;

Arise! and drain a morning draught with me!

Away with gloom ! full many a dawn will break

Looking for us, and we not here to see."

WIINFIELD.

"Hirs ast ki jumla ra ba dam andazad

Wa andar talab-i-mal haram andazad

Hirs ast ki jumla khalq ra za asaish

Baz arad wa dar ranj-1-mudam andazad."

ANWAR-1-SUheIL.

" 'Tis greed which doth enmesh all living; greed

That makes us follow most unrighteous gain ;

Greed robs all creatures of the rest they need

And steeps their being in perpetual pain."

Eastwick.

" Hushyar-1-huzur wa mast-1-ghurur

Bahr-1-tauhid wa gharqa'e gunahem,

Ganj dar astin wa kisa tihi

Jam-i-gitinuma wa khak-1-rahim."

HaFIZ, Ode, 418.

"Meek in the Presence, with conceit we're drunk, .

Seas of the unity, in sin we're sunk ;

With treasure in our sleeves, with empty purse,

We, though road-dust, reflect the universe."

(BICKNELL).

" Hubbu 'salamati yathni 'azma sahibihi

'Ani 'lma'all wa yughri 'Imara bi'lkasali;

Fa'in janahta ilaiha fa'ttakhidh nafaqan

Fi'lardhi au sullaman fl 'ljawwi f'atazili

Wa d'a ghimara 'l'ula lilmuqqadimin 'ala

Rukubiha wa'qtan'i minhunna bi'lbalali."

TUghrai.

"Ah Selim ! shall the spells of ease

Thy friendship chain, thine ardour freeze

Wilt thou, exhausted thus decline

Each gen'rous thought, each bold design?

Then far from men some cell prepare

Or build a mansion in the air

But yield to those ambition's tide

Who fearless on its waves can ride,

Enough for thee, if thou receive

The scattered spray the billows leave." J. D. Carlyle. 
"Hujjatash in àst wa guyad har dame

Gar budi chize digar, man didame, Gar nabinad kudake ahwal aql Aqile hargiz kunad az aql naql War nabinad aqile ahwal-i-ishq Kam na gardad mah niku fal ishq."

Jalaluddin RUmi.

"His argument is this; he says again and again

'If there were aught beyond this life, we should see it.'

But if the child sees not the state of reason, Does the man of reason therefore forsake reason?

And if the man of reason sees not the state of love Is the blessed moon of love thereby eclipsed?"

WHINFIELD.

“ Hujum-i-nafs wa hawa k'az sipah-i-shaitanand Chu zur bar dil mard-i-khuda-parast aurad, Bi juz junud hikayat rahnumayan-ra

Chi tab an gah bar an rahzanan shikast arad."

Jami Beharistan, chap. $\mathbf{I}$.

"When passion and lust which are combatants for Satan

Assail the heart of a God-fearing man,

Only the armies of maxims of directors

By their power defeat those highway robbers." (REнAтsek).

" Hukama gufta and 'a'lamat ahmaqi panj chiz ast, awwal talabi-manfa'at-i-kbwish dar mazzarat-i-digaran kardan, duyam sawabj-akhirat bi riyazat wa ibadat chashm dashtan, siyum ba durusht gui wa tund khui ba zanan ishqbazi namudan, charam ba tan asani wa rahat daqqaiq-i-"ulum danistan, panjam bi wafadari wa ra'iyat haqquq yari tawaqq'i dusti az mardum namudan."

Anwar-i-Suheili.

"Sages have said : 'five things are marks of folly : first, to seek one's own advantage by injuring others; secondly, to look for the rewards of the future life without mortifying the flesh and piety; thirdly, to make love to women with rough language and ill temper; fourthly, to expect to learn the niceties of science in slothful indulgence and ease; fifthly, to expect friendship from men without being faithful and observing the duties of a friend."

EASTWICK.

"Hukm-i-Sultan ba shan-i-atish wa ab

Dar dame 'alame kharab kunad,

Pas chunin hukmra rawa na bud,

Ki shah az rue iztirab kunad."

Anwar-1-Suheili.

" Like a fierce fire or a raging ocean

Commands of monarchs may destroy a world ;

It fits not then in times of wild emotion

The thunders of their will be round them hurled."

EASTWICK. 
- Huma'e chun tu aliqadr hirs-i-ustukhan bakti? Darigh an saya'e himmat kd ba murdar afghandi l"

ANWAR+1-SUHELLI.

"Can a phœnix such as thou condescend to carrion?

Fie! that such a glorious shadow o'er a carcase should be thrown."

(EASTWICK).

" Humal bar hama murghan az an sharaf darad

Ki ustukhwan khurad wa ta'ire niazarad."

Gulistan, chap. 1.

"The Huma (Phœenix) is for this of lirds the king

It feeds on bones and hurts no living thing." (EAsTwick).

"Hunar chashma'e zayinda ast wa daulat-i-payinda, wa agar hunarmand az daulat biuftad gham nabashad, ki hunar dar nafs-ikhud daulatast."

Gulistan, chap. 7 .

"Knowledge is an ever-springing fountain, and a source of enduring wealth, and if an accomplished person ceases to be wealthy it matters not, for his knowledge is wealth existing in his mind itself." (EASTwICK).

"Hunar chu mushk buwad, agar nihan manad, Za faiz raiha'e u mashamra khabar ast."

ANWAR-1-SUHEILI.

"Like musk is moral worth ; from sight concealed,

'Tis by its odour to the sense revealed." EASTwICK.

"Hunar na mi-kharad ayyam z'an shikasta dilam Kuja rawam ba tajarat badin kasad mita!"

ANWAR-I-SUhetL.t.

"These times refuse to purchase merit, therefore breaks my heart,

For gcar then so unvalued where shall I go seek a mart ?"

EAstwick.

" Hunarwar chunin zindagani kunad

Jafa binad wa mihrbani kunad."

BOSTAN OF S'ADI, chap. 4.

"The skilful one possesses life in this way,

He suffers violence and exercises kindness." (CLARKE).

" Husni-in nazm az bayan mustaghnist,

Ba furugh-i-khur kase juyad dalil?

Afrin bar kilki naqqash! ki dad

Bikri m'ana ra chunin husni jamil.

Kas niyarad guft ramzi z'in namat

Kas nadanad suft durri z'in qabil."

HAFIZ.

"The beauty of these verses baffles praise

What guide is needed to the solar blaze?

Extol that artist by whose pencil's aid

The virgin Thought so richly is arrayed ;

By me as by none else are secrets sung,

No pearls of poesy like mine are strung."

BiCKNell. 
" Husn-i-mah-ra ba tu sanjidam bi-mizan-i-kiyas

Palle-i-mah bar falak shud, u tu mandi bar zamin."

(RASIKH).

"I weighed thy beauty against that of the moon in the balance of my judgment :

The scale containing the moon flew up to heaven, and thou were left on the earth."

(E. G. Browne).

" Husnu dhanika bi'l'ayyami m'ajazatun

Fadhunna sharran wa kun minha 'ala wajali

Ghadha 'lwafa'u wa fadha 'lghadru w'anfajarat

Masafatu 'lkhulf baina 'lqauli wa'l'amall."

Tughrai.

"Too long my foolish heart had deemed

Mankind as virtuous as they seemed;

The spell is broke, their faults are bare,

And now I see them as they are,

Incredulous, I listen now

To every tongue and every vow,

For still there yawns a gulf between

Those honied words and what they mean."

J. D. Carlyle.

"Huwa 'lladhi ja'ala 'shshamsa dhiy'an wa'lqamara nuran wa qaddarahu manazila litalamu 'adada' ssinina wa' lhisaba, ma khalaqa 'llahu dhalika illa bi'lhaqqi yufassilu 'layati liqaumin ya'lamun."

KORAN, chap. Io.

"It is He who hath appointed the sun for brightness and the moon for a light, and hath ordained her stations that ye may learn the number of years and the reckoning of time. God hath not created all this but for the truth. He maketh His signs clear to those who understand."

(RODWELL).

"Huwa 'lladhi 'arsala rasulahu bi'lhuda wa dini 'lhaqqi liudhirahu ala 'ddini kullihl wa lau kariha 'Imushriqin."

KORAN, chap. 6r.

" $\mathrm{He}$ it is who hath sent His apostle with guidance and the religion of truth, that, though they detest it who join other gods with God, He may make it victorious over every other religion."

(RODWELL).

" Huwa 'lladhi madda 'l'ardha wa ja'ala flha rawasia wa 'anharan wa min kulli 'ththamarat ja'ala flha zaujaini 'thanaini yughshi 'llalla 'nnahara 'inna fl dhalika l'ayatin liqaumin yatafakkarun."

KORAN, chap. 13.

" $\mathrm{He}$ it is who hath outstretched the earth and placed on it the firm mountains and rivers; and of every fruit He hath placed on it two kinds : He causeth the night to enshroud the day. Verily in this are signs for those who reflect."

(RODIVELL).

"Huwa 'lladhi yurikumu 'lbarqa khaufan wa tama'an wa yunshi'u 'ssahaba 'ththiqal."

KORAN, chap. I3. 
"He it is who maketh the lightning to shine unto you for fear, and for hope of rain, and who bringeth up the laden clouds." (RODWRLL).

"Huzuri gar hami khwahi, az u ghaib ma shu, Haflz, Mata ma talqa man tahwa, d'ai 'ddunya wa ahmilha."

"If joy by thy desire, O I Iafiz, HAFIZ ODE, I. From Him far distant never dwell ; 'As soon as thou hast found thy loved one, Bid to the world a last farewell."

(BICKNELL).

“Idfa 'b'lliati hia 'ahsanu fa'idha 'lladhi bainaka wa bainahu "adawatun ka'annahu wahiyyun hamim."

KORAN, chap. 4 r.

"Turn away evil by what is better, and lo! he between whom and thyself was enmity shall be as though he were a warm friend."

(RODWELL).

"'Idh 'akhadha rabbuka min bani Adama min dhuhurihim dhur riyyatahum wa 'ashhadahum ala 'anfusihim 'alastu birabbikum qalu bala."

KORAN, chap. $7 \cdot v \cdot 17$

"When thy Lord brought forth their descendants from the reins of the sons of Adam, and took them to witness against themselves, 'Am I not' said He 'your Lord.' They said 'Yes." " (RoDwelL).

"Idha balaghati 'ttaraqia, wa qila man raqin, wa dhanna 'annahu 'Ifiraq, we'ltaffati 'ssaqu bi 'ssaqi, ila rabbika yanma idhin 'Imasaq."

KORAN, chap. 75 .

" When the soul shall come up to the breast-bone, and there shall be a cry 'Who is the magician to restore him ?' and the man feeleth that the time of his departure is come, and when one leg shall be enlaced with the other, to thy Lord on that day shall he be driven on." (RodivelL).

"Idha 'ftakara 'lyahudiyyu nadhara fl hisabihi 'l'atiq."

Arab Proverb.

"When the Jew grows poor, he looks into his old accounts."

D. Stewari.

“' Idha ja'l nasru 'llahi wa 'lfathu, wa ra'aita 'nnasa yadkhuluna fl dini 'lahi 'afwajan, fasibbih bihamdi rabbika w'astaghflrhu, 'innahu kana tawaba."

KORAN, chap. IJo.

"When the help of God and the victory arrive, and thou seest men entering the religion of God by troops; then utter the praise of thy Lord, and implore His pardon ; verily He loveth to turn in mercy."

"Idha shabi'a 'lkamiyyu yasulu batshan

(Rodivell). Wa khawi 'ibatni yabtushu bi'lfirari."

Gulistan, chap. I.

"The well-fed warrior will with ardour fight,

The starved will be as ardent in his flight." (EAstwick). 
"Idha 'shshamsu kuwwirat, wa'idha 'nnujumu 'nkadarat, wa'idha 'ljibalu suyyirat, wa'idha 'l'isharu -uttilat, wa'idha 'Iwuhushu hushirat, wa'idha 'lbiharu sujjirat, wa'idha 'nnufusu zuwwijat, wa idha l'mauudatu su'ilat biayya dhambin qutilat, waidha 'ssuhufu nushirat waidha 'ssama'u kushitat waidha 'ljahimu su'irat, wa'idha 'ljannatu 'uzlifat, 'alimat nafsun ma 'ahdharat."

KORAN, chap. $8 \mathrm{r}$.

"When the sun shall be folded up, and when the stars shall shoot downwards, and when the mountains shall be set in motion, and when the camels ten months gone with foal shall be abandoned, and when the wild beasts shall be gathered together, and when the seas shall be swollen, and when souls shall be paired with their hodies, and when the damsel that had been buried alive shall be asked for what crime she was put to death, and when the leaves of the Book shall be unrolled, and when the heaven shall be stripped away, and when hell shall be made to blaze, and when Paradise shall be brought near, every soul shall know what it hath produced."

(RODWELI.).

“ 'Idha zulzilati 'l'ardhu zilzalaha wa'akhrajati 'l'ardhu 'asqalaha wa qala 'l'insanu ma laha yaumaidhin tuhaddithu 'akhbaraha bi'anna rabbaka 'auha laha."

KORAN, chap. 99.

"When the earth with her quaking shall quake and the earth shall cast forth her burdens, and man shall say 'what aileth her?' On that day shall she tell out her tidings because thy Lord shall have inspired her."

(RODWELL).

"' 'Ilaj waqi'a pish az wuqu 'bayad kard,

Darigh sud na darad chu raft kar az dast."

Anwar-1-Suhenl.I.

" Think of the cure before the thing occurs

He grieves in vain who till 'tis past defers." EASTwick.

"I'lamu 'annama 'lhayatu 'ddunya la'ibun wa lahwun wa zinatun wa tafakharun bainakum wa takatharun fllamwali wa'lauladi kamathali ghaisin ajjaba 'lkuffara nabatuhu thumma yahhiju fatarahu musfaran thumma yakunu hutaman." KORAN, chap. 57.

" Know ye that this world's life is only a sport and pastime and show, and a cause of vainglory among you. And the multiplying of riches and children is like the plants which spring up after rain, whose growth rejoiceth the husbandman; then they wither away and thou seest them all yellow; then they become stubble."

(RODWELI).

" "Il'aqi 'l'asala wa la tasal."

Maqainat of Hariri, (44).

" Lick up the honey and ask no questions."

Steingass.

" Ilm bi amal chu mum bi "asal."

Anwar-1-Suheill.

" Iearning without practice is like wax without honey." 
" Imruz dar an kush ki bina basht

Hairan-i-jamal-i-an dilara bashi,

Sharmat bada chu kudakan dar shab-1-4d

Ta cband dar intizar-i-farda bashi?"

AKHLAK·-JALALI.

" To-day aspire to this that thou may'st obtain sight

That thou may'st be enraptured with the charms of the beloved object,

Shame on thee! How long like children on the eve of a festival

Wilt thou still fondly anticipate the morrow?" (ASIATIC JouRNAL).

"Inda hububi 'nnashirati "ala 'lbima

Tamilu ghusunu 'Iban!, la'lhajaru 'ssaladu."

"When the scattering winds blow over the meadows

The branches of the ben-tree bend, not the hard rock."

Gulistas, chap. 2.

" 'Indahu mafatihu 'lghaibi la ya'lamuba illa huwa wa y'alamu ma fl'barri wa 'lbahri wa ma tasqutu min waraqatin illa ya'lamuha wa la habbatin fl dhulmati 'l'ardhi wa la ratbin wa la yabisin illa fi kitabin mubin."

KORAN, chap. 6.

"With Him are the keys of the secret things; none knoweth them but $\mathrm{He}$ : and He knoweth whatever is on the land and in the sea, and no leaf falleth but He knoweth it ; neither is there a grain in the darknesses of the earth nor a thing green or sere but it is noted in the perspicuous Book."

" In daira'e jahan chu angushtarist

(RODWELL).

Bi hich shake naqsh-i-naginash ma em."

OMAR KHAYYAM.

"This circle of the universe resembles a ring,

Unquestionably we are the signet engraved on its bezel."

"In hama hich ast chun mi bugzarad

(Nicholson).

Bakht wa takht wa amr wa nahi wa gir wa dar

Nam-i-nik-raftagan za'l makun

Ta bamanad nam nikat bar qarar."

Gulistan, chap. I.

"These are no more than trifles swiftly sped,

Fortune and throne, command and conquest-all.

Destroy not thou the good name of the dead

That thy fame, too, may last and never fall." (EAsTwICk).

" In hukm wa ghurur wa khashm ta chand

Hast az tu buzurgtar khudawand,

Ey khwaja'e Arslan wa Aghush

Farman-dih-i-khud ma kun faramush."

Gulistan, chap. 7.

"Soon must thou anger, rule, and pride resign

There is a Lord whose sway surpasses thine

Thou'rt master of Arslan * and Aghush * yet

Beware, lest thine own master thou forget."

EAstwick.

* Names of slaves. 
"In huwa illa wahlun yuha allamahu shadidu 'lquwa dhu mirratin fa'stawa wa huwa bilu'fuki 'l'ala, thumma dana fatadalla, fakana qaba qausaini au 'adna, fa'auha ila 'abdihi ma 'auha."

KORAN, chap. 53 .

" Verily the Koran is no other than a revelation revealed to him; one terrible in power taught it him, endued with understanding. With even balance stood he, and he was in the highest point of the horizon; then came he nearer and approached closely, and was at the distance of two bows or even closer, and he revealed to his servant what he revealed."

(RODWELL).

\section{"In jahan ba misal mur dar ast \\ Gargasan gird-i-u hazar hazar \\ In mar anra hamizanand mukhallab \\ An mar inra hamizanand minqar. \\ Akhiru 'l'amr bar parand hama \\ Wa za hama baz manad in murdar."}

ANWAR-I-SUheILI.

"The world is to a carrion-carcase like

Round which a myriad vultures without pause

A contest wage. These with their talons strike

Those who in turn wound them with beak and claws

At length they spread their wings and soaring quit

Their evil prey, nor can they taste or come near it."

Eastwick.

" In jahan kuhast wa fi'l-i-ma nida

Sue ma ayad nidaha ra sada ;

Garchi diwar afganad saya'e daraz

Baz gardad sue u an saya baz."

ANWAR-I-SuHeILI.

"The world a hill is and our acts a shout

And back the hill to us the echo spurns

Though long the shadow that a wall throws out,

That shadow dwindling to the wall returns." EASTwICK.

In jam'a-i-akabir ki manasab darand

Az ghussa wa gham za jan-1-khud bizarand

Wa ankas ki asir-i-hirs chun ishan nest

Wa in tarfa ki admish mi nashumarand."

Omar Khayyam.

"Strange! the great lord, the wealthy citizen

Find their own lives a burden sore, but when

They meet with poorer men, not slaves to sensc,

They scarcely deign to reckon them as men."

(WHINFIELD).

“ In kana lirrahmani waladun, fa'ana 'awwalu '1'abidin."

KORAN, chap. 43. him."

"If the God of mercy had a son, the first then would I bc to worship (RODWELL). 
"In ki mibinam ba be dar ast, ya rabb, ya bakhwab, Khwishtan ra dar chunin ni'mat pas az chandin "azab."

ANWAR-1-SUHEILI.

"In slumber see I this my God, or with nyy waking eyes Myself in plenty such as this after such agonies?"

EAstwick.

"In mahalla wa in martahala, wa inna fl 'ssafari idh madhu mahala Astathara 'llahu bi 'Iwafa wa b'll'adi wa wala 'Imalamata 'rrajala."

Abu's. Al.s.

"Truly there is a time for resting and a time for travelling, and a time for the traveller to linger. God has claimed for himself justice and faithfulness and assigned the blame to man." D. S. MARGoliouth.

“'Inna 'anzalnahu fl lailatí 'Iqadri, wa ma 'adraka ma lailatu 'Iqadri, lailatu 'Iqadri khairun min 'alf shahrin, tanazzalu 'Imala'ikatu wa'rruhu flha bi'idhnin rabbihim min kulli 'amrin, salamun hia hatta matla'i 'lfajri."

KORAN, chap. 97.

"Verily we have caused It to descend on the night of power, and what shall teach thee what the night of power is? The night of power is better than a thousand months. Therein descend the angels and the Spirit by permission of their Lord for every matter; all is peace until the breaking of the morn."

(RODWELL).

"Inna 'aradhna 'l'amanata ala 'ssamawati wa'l'ardhi wa'ljibali fa'abaina 'an yahmilnaha wa 'ashfaqna minha wa hamalaha 'IInsanu innahu kana dhaluman jahulan."

Koran, chap. 33 .

"Verily we proposed to the heavens and to the earth and to the mountains to receive the Faith, but they refused the burden and they were afraid of it. But man undertook to bear it for he is unjust, senseless."

(RODWELL).

" Inna 'ash'ara baltin anta qa'lluhu,

Baitun yuqalu, Idha 'anshadtahu, Sadaqa."

ZUHAIR.

"Of all the verses which thou hast made, the fairest in praise is that whereof, when they hear men say "Y'ea, that is the truth.",

(C. J. LYALL).

" 'Inna bilsh 'ibi 'lladhi duna Sal'in laqatilan damuhu ma utallu Khalaffa 'l'ib'a 'alayya 'ana bi 'lib'a lahu mustaqillu."

'Aabbata Sharkan.

"In the cleft of the rocks below Sal" is lying

One slain whose blood drips not without vengeance

IIe left the burden to me and departed

And I take up the load lightly and bear it." C. J. LyalL. 
“ Inna 'dhdhanna la yughni mina 'lhaqqi shaian." KoraN, chap. 53. "Truly mere conceit can profit nothing against the truth."

(RODWELL).

"Inna khalaqnakum min dhakarin wa 'untha wa ja'alnakum shu'uban wa qaba'ila lita'arafu 'inna 'akramakum 'inda 'llahi 'atqakum."

KORAN, chap. 49.

"Verily we have created you of a male and of a female, and we have divided you into peoples and tribes, that ye might take knowledge one of another. Truly the most worthy of honour in the sight of God is he who feareth Him most."

RODWELL.

"Inna khulasata 'ljauhari tadharu bi 'ssabki, wa yadu 'lhaqqi tasd'au rida'a 'shshakki." MAQAMAT OF HARIRI, chap. 2.

" Truly the purity of the gem is shown by the testing, and the hand of truth rends the cloak of doubt."

Chenery.

"Inna 'l'insana khuliqa halu'an, idha massahu 'shsharru jazu'an, wa' idha massahu 'lkhairu manu'an."

KORAN, chap. 70 .

" Man truly is by creation, hasty; when evil befalleth him, impatient ; but when good falleth to his lot, tenacious."

(RODWELL).

"Inna 'llaha la yughayyiru ma biqaumin hatta yughayyiru ma bi anfusihim wa idha 'aradha 'llahu biqaumin su'an fa la maradda lahu wa la lahum min dunihi min wal."

KORAN, chap. I3.

"Verily God doth not change His gifts to a people till they change what is in themselves; and when God willeth evil to a people, there is none can turn it away nor have they any protector beside Him."

ROIWELL.

"Inna 'llaha yahulu baina "Imar'a wa qalbihi." KORAN, chap. 7.

" God cometh in between a man and his own heart."

(RODWELL).

"Inna 'llaha yuhibbu 'lladhina yuqatiluna fi sabilihi saffan ka'annahum bunyanun marsusun."

Koran, chap. 6r.

"Verily God loveth those who, as though they were a solid building, do battle for his cause in serried lines."

(RODWELL).

“ Innama auladuna bainana 'akbaduna tamshi 'ala l'ardhi

Lau habbati 'rrihu ala b'acthihim l'amtan'aat mina 'lghamdi."

" Nay but our children in our midst what else

HitTan.

But our hearts are they, walking on the ground?

If but the breeze blow harsh on one of them,

Mine eye says no to slumber all night long." C. J. Lyal. 
"Innama 'Imu'minuna 'Ikhwatun fa'aslihu baina 'akhawaikum wa'ttaqu'llaha la'allakum turhamun."

KorAs, chap. 49.

"The faithful are brethren; wherefore make peace between your brethren and fear God ; haply ye may obtain mercy." (RonwelL).

"Innama qauluna lishaian idha 'aradhnahu 'an naqula lahu kun fayakun."

KORAN, chap. 36.

"Our word to a thing when we will it, is but to say 'Be' and it is."

(RODWELL).

"Innama sahibu 'dirhamaini ghanniyun "inda sahibi 'dirhami wa 'laftasu ashamma fl takhiyali 'l'akshaml."

ABu'L Ala.

"A man with two dirhems is rich in the eyes of him who has only one, and a snub-nosed man aquiline as compared with him who has no nose at all."

D. S. Margoliouth.

"Innama yahfadhu 'ttuqa 'l'abrar,

Wa 'ila 'llahi yastaqirru 'lqararu

Wa ila 'llahl turja'una wa "inda 'llahi wirdu 'lumuri wa 'l'isdaru."

DiwaN of LEBid.

"Yea, the righteous shall keep the way of the righteous

And to God turn the steps of all that abideth,

And to God ye return, ye too: with Him only

Rest the issues of things and all that they gather."

C. J. Lyall.

'Innama yutajamilu inda 'l'gharibi, la 'lqaribi, w'al sahibu 'lwad 'ulbadi, dun sahibu 'lwada 'l'abadi."

ABu'L Ala.

"We only put on airs before strangers, not before relations, and before new friends, not before those of old standing." D. S. MARGolioutr.

"Inna qusara maskani 'lhayy hufratun .

Sayanziluha mustanzalan 'an qibabihi ;

Fawahan li'abdin sa'hu sa'u f'ilihi,

Wa 'abda 'ttalafl qabla "ighlagi babihi." Maqamat of Hariri (21).

"The end of the dwelling of the living is a pit, to which he shall descend brought down from his towers,

Then well-done! the servant whom the evil of his deed grieves and who shows amendment before the shutting of his gate." (CHENERY).

"Inna safaha shsheikhí la hilma b'aduhu

Wa'inna 'lfata b'ada 'ssafahati yahlumi." Muleakair of Zuhair.

"If a man be old and a fool his folly is past all cure,

But a young man may yet grow wise and cast off his foolishness."

C. J. Lyall. 
"Inna 'ttibra fl 'irqi 'ththara khafin 'ila 'an yustathara binabshihi Wa fadhllatu 'ddinari yadharu sirruha min hakkihi la min malahiti naqshihi." Maqamat of Hariri (2r).

"The pure gold in the vein of the earth is hidden until it is brought out by the digging,

And the worth of the denarius, its secret appears by scratching it and not from the leauty of the engraving."

(ChENERY).

"Inni lamustatirun min 'aini jirani

Wa 'llahu yalamu israri wa i'lani."

Gulistan, chap. 2.

" True I may be from neighbours' eyes concealed

God knows my acts both secret and revealed."

(EASTWICK).

" In qaflla'e umr 'ajab mi guzarad, Daryab dame ki az tarab mi-guzarad

Saqi gham-i-farda'e harifan che khuri?

Plsh ar piyala ra ki shab mi-guzarad."

OMar Khayyan.

" Life's caravan is hastening on its way, Brood not on troubles of the coming day, But fill the wine-cup ere sweet night be gone, And snatch a pleasant moment while you may."

WHINFIELD.

" 'In taqtadir, fa'sfah fa la khaira fl'mrin

Idha "atalaqat 'adhfarahu bi 'shshawa, shawa."

MAQAMAT OF HARIRI, cliap. 47.

" Pardon if thou art strong, for no good is in a man, who needlessly wounds, when power of wounding is in his grasp."

"In tansuru 'llaha yansurkum wa yuthabbit 'aqdamakum."

KORAN, chap. 47.

"If ye help God, God will help you, and will set your feet firm."

(RODWELL).

" 'In yamsaska 'llahu bidhurrin fala kashifa lahu, illa huwa wa'in yuridka bikhairin fala radda lifadhlihi yusibu bihi man yashau min ibadihl."

Koran, chap. ro.

" If God lay the touch of trouble on thee, there is none to remove it but $\mathrm{He}$; and if He would confer good upon thee there is none to keep back his bounty; He will confer it on such of His servants as $\mathrm{He}$ chooseth."

(RODWELL).

“ 'Iqra 'b'ismi rabbika 'lladhi khalaqa, khalaqa 'l'insana min 'alá, 'iqra wa rabbuka 'l'akramu, 'lladhi allama b'ilqalami, allama 'linsana ma lam ya'lama."

Koran, chap. 96 . 
" Read! in the name of thy Lord who created;-created man from clots of blood. Read! for thy Lord is the most beneficent, who hath taught the use of the pen; hath taught man that which he knew not."

(ROI)WELL).

"Iqtaraba linnasi hisabuhum wa hum fl ghaflatin mu'ridhun."

KORAN, chap. 2 I.

"This people's reckoning draweth nigh, yet, sunk in carelessness they turn aside."

(RODWELL).

"Isa, ruh-i-tu ba tu hazir ast

Madad az way khwah k'u khush nasir ast." Jalaleddin Rum.

" Jesus, thy spirit, is present beside thee, Ask aid of Him for He is a sufficient helper."

“ Isa'e Maryam bafalak raft wa faru mand kharash Man bazamin mandam wa shud janib-i-bala dil-i-man."

Diwan-I-Shanis-I-TABRI7.

" Jesus, son of Mary, went to heaven and his ass remained below, I remain on the earth but my spirit has flown to the sky."

(Nicholson).

"Ishq an shu'ala ast ki chun bar farukht, Har ki juz m'ashuq, baq1 jumla sukht."

JALALUDDIN RUMI.

"Love is that flame which, when it is kindled, Devours everything except the Beloved."

' Ishq ast dar asman paridan

Sad parda bar har nafas daridan."

"This is Love; to fly heavenward

To rend every instant a hundred veils." (NicholsoN).

"Ishq burd bahs-ra, ey jan, wa bas,

Ku za guftugu shawad faryad-ras;

Hairati ayad za ishq an nutq-ra

Zahra na buwad ki kunad u majra

Lab ba bandad sakht $u$ az khair wa sharr

Ta mubada az dihan uftad gauhar."

Jalaluddin Rumi.

" Love of God cuts short reasonings, $O$ beloved,

For it is a present refuge from perplexities.

Through love bewilderment befalls the power of speech

It no longer dares to utter what passes;

Therefore it closes lips from saying good or bad

So that its treasure may not escape it."

(WHINFIELD). 
" Ishqe ki hast t'abi taba " wa hawa'e nafs Khasiyat taba' saba" wa bahaim ast."

JAMI, BiHARISTAN, chap. 5 .

"The love which follows nature and sensual appetite

Is a quality of the nature of animals and beasts of prey."

RehatseK.

"Ishq wa jan har du nihanand wa satir

Gar 'arusash khwanda am 'aibi magir.

Az malul yar khamush kardami

Gar ham u muhlat badadi yak dame.

Lek mi guyad 'bigu hin aib nist,

Juz taqaza-e-qaza-e-ghaib nist.

Aib bashad k'u na binad juz ki aib

Aib kai binad ru an pak ghaib."

JAI.ALUDDIN RUML.

"Love and mistress are both veiled and hidden

Impute it not as a fault if I call Him 'Bride.'

I would have kept silence from fear of my Beloved

If He had granted me but a moment's respite.

But He said, 'Speak on, 'tis no fault,

'Tis naught but the necessary result of the hidden decree

'Tis a fault only to him who only sees faults

How can the Pure Hidden Spirit notice faults."

(WHINFIELD).

"Ishq ki majazi bud, abash na bud

Chun atish-i-min murda tabash na bud

Ashiq bayad ki mah wa sal wa shab wa ruz

Aram wa qarar wa khurad wa khabash na bud."

Omar Khayyam.

" Love only surface-deep is counterfeit, And like a half-spent blaze, lacks life and heat;

True love is his who for long months and years

Rests not, nor sleeps, nor craves for drink nor meat."

WHINFIELD.

"Isna" bi ma 'anta lahu 'ahluhu wa la taf"al bina ma nahnu biahlihi."

Gulistan, chap. 2.

"Do unto me that which is worthy of thee, and not that of which I am worthy."

(EAsTivick).

"Istajibu lirabblkum min qabli 'an ya'tla yaumun la maradda lahu min 'llahi ma lakum min malja'i yauma'idhin wa ma' lakum min nakir."

KORAN, chap. 42 .

"Hearken to your Lord ere the day come, which there will be no averting on the part of God. No place of refuge for you on that day! no disavowal of your works."

(RODWELL). 
" 'Itiraz ast bar ahkam jahandar hakim

Adat mard-1-hasad pashi ki khakash bidihan

Har chi binad bikaf-1-ghair flghan bar darad,

Ki 'chira dad ba-wal anera na baman?'" Jami, BHARISTAN, chap. 2.

"The habit of an envious man.-be his mouth filled with dust !

Is to find fault with the decisions of the wise ruler of the world;

Whatever he sees in another man's grasp he bemoans, saying,

"Why was it given to him without cause and not to me?"

"Ittisale bi-taqaiyuf bi qiyas

Hast baina 'nasa wa Rabb 'annas."

(REHATSEK).

" Union exists beyond all thought and speech

Between great Allah and the soul of eacl."

" 'Iyan na shud ki chira amadam, kuja budam,

Darigh wa dard ki ghafl za kar-i-khwishtanam ;

Chiguna tawaf kunam dar faza'e 'alam-i-quds

Chu dar saracha'e tarkib takhtaband am;

Mara ki manzar-i-hurast maskan wa mawa

Chira bikui kharabatian buwad watanam."

HAFIZ, Ode, $3^{85}$.

"Wherefore I came, and where I was have now faded from my mind :

Alas of what concerns myself no remembrance can I find,

Around the IIoly World's expanse can I make my circuit aye,

As long as by this body pent, in this mixed abode I stay?

Shall I whose dwelling and abode is the huri's lofty dome,

Continuc to acknowledge here in the revellers' lane my home."

" Izid babihisht w'ada ba mal kard

(BICKNELL).

Pas dar du jahan haram maira kai kard."

Omar Khayvam.

"Allah hath promised wine in Paradise,

Why then is wine on earth declared a vice."

" Izid faramushat na kard dar an hal

(WHINFIELD).

Ki budi nutfa'e madfun wa madhush ;

Ruanat dad wa aql wa tab'a wa Idrak

Jamal wa nutq wa rae wa flkrat wa hush ;

Dih angusht marattab kard bar dast

Do bazuat marakkab sakht bar dush ;

Kunun pindari, ai na-chiz himmat,

Ki khwahad kardanat ruze faramush."

Gulistan, chap. 7 .

"Thou wast by God then not forgotten, when

Thou wast a seed, thy nature in suspense ;

He gave thee soul and reason, wisdom, ken,

Beauty and speech, reflection, judgment, sense ;

He on thy arm arrayed thy fingers ten,

And thy arms fastened to thy shoulders. Whence

Canst thou then think, $O$ thou most weak of men !

He'll be unmindful of thy subsistence."

(EASTWICK). 
" 'Izzat an yaft ki barkand dil az mihr-i-jahan

Rahat an did k'az an dast-i-tama“ baz kashid." ANwar-1 SUHEILI.

" Who tear their hearts from worldly things the sole true honour find,

And they have peace who from its gauds and show withdraw their mind."

EASTWICK.

"Ja'a 'lhaqqu wa zahaqa 'lbatilu, 'inna lbatila kana zahuqa."

KORAN, chap. r7. $\vee .83$

"Truth has come and falsehood has vanished, verily falsehood is fleeting."

“ Ja'alna 'llaila wa'nnahara ayataini, wa mahvna ayata 'llaili wa ja'alna ayata 'nnahari mubsiratan litabtaghu fadhlan min rabbikum wa lita'lamu 'adada 'ssinina wa 'lhisaba wa kulla shai'an fassalnahu tafsila."

KORAN, chap. 17.

"We have made the night and the day for two signs; the sign of the night do we obscure, but the sign of the day cause we to shine forth visibly, that ye may seek plenty from your Lord, and that ye may know the number of the years and the reckoning of time; and we have explained. everything with clear explanation."

(RODWELL).

"Jahan Afriniyat kushaish dihad

Ki gar wai bibandad nashayad kushad." BOSTAN OF S'AdI, chap. 5.

" May the world-creator give thee the means of opening the door, For if He shuts, none can open."

(CLARKE).

"Jahan, ey biradar, namanad bakas

Dil andar jahan-i-afrin band wa bas

Makun takiya bar mulk-i-dunya wa pusht

Ki bisyar kas chun-i-tu parwarad wa kusht.

Chu ahang-i-raftan kunad jan-i-pak

Chi bar takht murdan, chi bar ru-e-khak."

Gulistan, chap. r.

" The world, my brother, will abide with none, By the world's maker let thy heart be won, Rely not nor repose on this world's gain

For many a son like thee she has reared and slain.

What matters, when the spirit seeks to fly

If on a throne or on bare earth we die."

(EASTWICK).

"Jahan az aql wa nafas wa charkh wa ajram Chun yak qatra dan za aghaz ta anjam."

Gulshan-I-Raz.

" The world which is composed of intellect, soul, heavens and bodies, Know them to be as a drop from beginning to end."

(TROYER).

"Jahan gashta az adlash arasta

Wa z'an gard bi-dad barkhasta."

ANWAR-I-SuHEILI.

" His justice added to the world fresh grace And swept oppression dust-like from its face." Eastwick. 
"Jahan misal-i-tan-1-bisarast bi an shah

Ba plch gird-1-chunan sar misal-i-dast dare, Agar slyah na'l, aina ma dih za dast Ki ruh aina'e tust, Jtsm zangare."

DIWAN-1-SHAMS-1-TABRIZ.

"The world without that king is like a headless body ;

Fold yourself turban.wise, round such a head.

Unless you are black, do not let the mirror go from your hand

The soul is your mirror, while the body is rust." Nicholson.

"Jahan ra az bakhshish pur awaza dar

Hama waqt shu dar karam mustaqim

Ki hast Afrinanda'e Jan karim."

Pandnama of S'adi.

"Fill the world with the fame of your beneficence At all times be steadfast in active goodness

Since the Creator of the soul is beneficent." Gladwix.

" Jahan ra bih az 'adl mi'mar nist

$R$ 'aiyat darigh az ra'iyat madar

Murad-i-dil dad khwahan barar."

PaNdNaMa of S'Adi.

"The world has no architect superior to justice

Withhold not favour from the peasant

Gratify the hearts of the suppliants for justice."

“ Jahan-ra nist hasti juz majazi

Sarasar hal-i-u lahv ast wa bazi."

(GLadwiN).

GULShAN-1-RAz.

"The world has no existence but as a metaphoric image

Its state is entirely a farce and a play."

(Shea).

"Jahansuz ra kushta bihtar chiragh ;

Yake bih dar atish ki khalqe ba dagh."

ANwar-1-SUheil.,

"The lamp of an incendiary

Is better quenched. That one should dic

And fiery torments undergo,

Is better than all mankind's woe."

EAstwick.

“ Jam 'ast ki aql-i-afrin mi-zanadash

Sad busa za mihr bar jabin mi-zanadash

In kuzagar-i-dahr chunin jam-i-latif

Mi-sazad wa baz bar zamin mi-zanadash."

OMar Kilayyam.

"There is a chalice made with art profound, And with its Maker's approbation crowned, Yet the world's Potter takes His masterpiece And dashes it to pieces on the ground."

WhiNFIELD.

"Jahil ar ba tu numayad ham dili

Aqibat zakhmat zanad az Jahlli."

JALAI.UdDIN RUMi.

"Although a fool may show you sympathy

At the end he will wound you with his folly." 
"Jam'a ast khairha hama dar khana wa nist

An khana-ra kalid baghair az farutani." JaMi, BeHaristan (chap. x).

"All benefits are in one house, and there is

No other key to it except humility." (ReHatsek).

"Jama'e k'abara ki mi-pushand

U na az kirm-i-pila name shud;

Ba 'azize nishast ruze chand,

La jarm hamchu u girami shud."

GULISTAN, chap. 7.

" The pall suspended o'er the K'aba's shrine, Not from the yellow worm* derives its fame, But it has dwelt some days near the divine, And therefore do men venerate its name." (Eastwick).

" Jamal-i-bakht zi rue zafar niqab andakht

Kamal-1-'adl bafaryad-i-dadkhwah rasid

Sipihr daur-i-khush aknun zanad ki mah amad

Jahan bakam-i-dil aknun rasad, ki shah rasid."

HAFIz.

" The veil from victory's face the beauty of fortune hath cast,

To the complaint of the complainers the perfection of justice hath arrived,

Now the sky displayeth a sweet revolution for the moon hath come,

Now to the heart's desire the world arriveth, for the king hath arrived."

"Jami az alaish-i-tan pak shu"

(Clarke).

Dar qadam-1-pak rawan khak shu."

The Dabistan.

"Be thou as a goblet free from the contamination of body

Be thou earth in the footsteps of the pure."

(SHEA).

" Jamila ast 'arus-i-jahan wale hushdar

$\mathrm{Ki}$ in mukhaddara dar "aqd kas na ayad."

Anwar-1-Suhelli.

" A fair bride is the world; but yet, be wise,

For none may wed this coy and curtained prize."

"Janaha'e khalq pish az dast wa pa

Mi paridand az wafa andar safa."

EASTWICK.

JaLALUDDIN Rumi.

"The souls of our first parents, even before their hands,

Flew away from fidelity after vain pleasure." WHINFIEI.D.

"Janam bi fida-e-anki u ahl bud

Sar dar qadamash agar niham sahal bud,

Khwahi ki badani bayaqin duzakhra

Duzakh bajahan suhbat-i-na-ahl bud."

Omar Khayyam.

* The silk-worm. 
"For him that's good my very life I'd sell, Yea, though he trod me down, I'd count it well, Men say 'Inform us what and where is hell?'

Bad company will make this earth a hell." WhiNFit.d.

"Janam m'alul gasht za Fir'aun wa zulm-i-u

An nur-i-rue Musa "Imranam arz'ust." Diwan-I-Shanis-I-Tabriz.

"My soul is grown weary of Pharaoh and his tyranny,

I desire the light of the countenance of Mloses, son of "Imran."

(Nicholson).

“Janan za dar-i-tu dur natawanam bud

Qan' bi bihisht wa hur natawanam bud,

Sar bar dar-i-tu bihukm-i-'ishq namabzar

Z'In dar chi kunam sabur, natawanam bud." Jami (Beharistan).

" My life ! I cannot keep myself far from thy door

I cannot be content with Paradise and the houris;

I lay my head at thy door for love not for hope of gain

And from that door I have not the patience to remove."

(Asiatic Journal).

“Janaza 'am chu babini magu 'flraq I fraq !

Mara wisal wa mulaqat an zaman bashad,

Mara bagur sipari magu 'wid'a! wid'a!'

Ki gur parda'e jam 'yaat-i-jinan bashad," Drwax-1-Shasis-l-Tabriz.

“ When thou seest my hearse, cry not, 'parted ! parted !'

Union and meeting are mine in that hour.

If thou commit to the grave, say not 'farewell! farewell!

For the grave is a curtain hiding the communion of Paradise."

(Nicholson).

"Jan chu aina safl ast bar $u$ tan gardast

Husn dar ma nanumayad, chu ba zir-i-gard'em."

DiwaN-I-SIIAMS-I-TABRIZ.

"The soul resembles a clear mirror, the body is dust upon it,

Our beauty is invisible since we are under the dust."

(Nicholson).

"Jan chist janin-i-nutfa-i-suib-i-gaza

Giti rihm ast wa tan mashima ast ura

Talkhi ajal dard-i-zih-i-madar dahr

In mur dan chist? zadan-i-malak-i-baqa."

BLZURGI.

"What is the soul? The seminal principle from the loins of destiny, This world is the womb: the body its enveloping membrane

The bitterness of dissolution Dame Fortune's pangs of child-birth.

What is dealh? to be born again an angel of eternity." (SHEA). 
"Jan chu ruz ast wa tan-i-ma chu shab wa ma bamiyan Wasta'e ruz wa shab-i-khwish misal-i-sahar em."

Diwan-l-Shats-1-TamRIz.

"The soul resembles day and the body night and we in the middle Are like the dawn between our own day and night."

(Nicholson).

"Jan dar himayat-i-yak dam ast wa dunya wujude miyan-i-du "adam."

Gulistan, chap. 8.

"Life hangs on a single breath and the world of existence is between two non-existences."

EASTWICK.

"Jang wa sulh be mahal ni ayad bakar

Jae gul gul bash wa jae khar khar."

ANWAR-I-SUHEILI.

" Inopportunely war or peace comes ill, Let flowers or thorns the place that suits them fill."

EASTWICK.

" Jauhare agar dar khilab uftad hamchunan nafis ast, wa ghubar gar ba falak rasad hamchunan khasis."

Gulistan, chap. 8.

"If a jewel fall into the mire, it remains as precious as before: and though dust should ascend to heaven its former worthlessness will not be altered."

(EASTIVICK).

"Jaur-i-dushman chi kunad gar na kashad talib-i-dust

Ganj wa mar wa gul wa khar wa gham wa shadi bahamand."

Gulistan, chap. 7 .

"Who would have friends a foe's hate must sustain; Linked are snakes, gold ; thorns, flowers ; joy and pain."

(EASTwick).

"Jawab ul ahmaq sakut."

Arab. Prov.

"The answer to a fool is silence."

" Jawan mard wa khush khue wa bakhshinda bash, Chu haqq bar tu pashad, tu bar khalq pash,

Niayad kas andar jahan k'u bamand

Magar an k'az u nam-i-niku bamand."

Bostan of S'ADI, chap. $x$.

" Be generous and pleasant-tempered and forgiving,

Even as God scatters favours over thee, do thou scatter over the people,

No one came into the world who remained

Save that one, whose good name remained."

(Clarke).

" Jawana ta'at imruz gir

Ki farda niayad jawana za pir."

SAADI.

"O youth! enter this very day into the path of obedience

For to-morrow the vigour of youth comes not from the aged man."

SHEA. 
" Jazba'e shakh abra az bikh ta bala kashid

Hamchunankl jazba janra bar kashad bi nirduban."

DIWAN-I.SHAMIS-I-TABRIZ.

"The bough's attraction drew the sap from root to summit,

Even as attraction draws the soul upward without a ladder."

(Nicholson).

" Jazbat shauqika aljamat bi salasili 'lgham wa ' bala Hama ashiqan shikasta dil ki dihand jan birah-i-wela, Agar an sanam za sar sitam pa'e kushtan-i-man bi gunah Laqad istiqama bi saifhi falaqad radhaitu bi ma radha."

KuKRat'Ul AYn.

"The thralls of yearning love constrain in the bonds of pain and calamity, These broken hearted lovers of thine to yield their lives in their zeal for thee,

Though with sword in hand my darling stand with intent to slay though I sinless be,

If it pleases him, this tyrant's whim, I am well content with his tyranny."

(E. G. BrowNE).

"Jazbatun min jazabati 'lhaqqi turba 'ala "amali 'ththaqalain."

ABu'L QASIM NASRABadi.

"One pull from God is better than all the actions of men and jinn."

(NICHOLSON).

"Jidd wa jihad kase ki beshtar ast

Karash az kar jumla peshtar ast."

Axwar-I-Suheilt.

"They who excel in zeal, in toil precede, Must of all others fairly take the lead." EAstivick.

“ Jihad-i-rizq war kuni wa gar na kuni

Birasanad khuda'e azz wa jall ;

Wa shawi dar dihan-i-shir wa palang

Nakhurandat magar ba ruz-1-ajal."

Gulistan, chap. 8.

" Would'st thou by toil or not thy wants supply

The Glorious and High God will give thee food.

Nor, mortal, can'st theu unpredestined die

Did'st thou in maw of ravenous tigers lie

Or savage lions thirsting for thy blood." (EAsTwick).

"Jihad mi-kun ta tawani, ey giya

Dar tariq ambiya wa auliya

Ba qaza panja zadan na bud jihad

Z'anki in ra ham qaza bar ma nihad;

Kaflr am man gar ziyan karda ast kas

Dar rah iman wa ta'at yak nafs." 
" Exert thyself, O man ; put shoulder to the wheel The prophets and the saints to initate in zeal. Exertion's not a struggle against Providence, 'Twas Providence enjoined it ; made it our defence Blasphemer may I be, if ever single man Bestowed in vain one effort to fulfil God's plan."

REDHOUSE.

"Jilu haza 'zzamani fa ma fihim man yamihu idha sigha lahu 'lmadihu wa la man yujizu idha 'unshida lahu 'l'arajizu wa la man yughithu idha 'atrabahu 'Ihadithu." Maqanat of Harrri (chap. 43).

" As for the people of this age, there is none among them who bestows a gift when an encomium has been fashioned for him, none who gives a reward when a poem has been recited to him, none who shows himself bountiful, when a tale has diverted him."

STEINGASS.

\section{"Jism bahrl ruh bashad gur tang}

Gur gar dar gur bashad sur bini, sur nist

Gur gar dar gur bashad zinda az zindan rihad." The Dabistan.

"The body is a narrow sepulchre which entombs every spirit,

When that tomb is entombed thou beholdest a wall that really is no wall,

When the tomb is entombed the living spirit is freed from its prison."

(SHEA).

"Jism-i-khaq az ishq bar afiak shud

Kuh dar raqas amad wa chalak shud,

Ishq jan-i-Tur amad, ashiqa,

Tur mast wa kharra Musa sai'qa.

Ba lab damsaz khud gar juftame

Ham chu nai man guftaniha guftame."

JaLALUDDin RUm.

" Love exalts our earthly bodies to heaven,

And makes the very hills to dance with joy!

O Lover, 'twas love that gave life to Mount Sinai

When it quaked and Moses fell down in a swoon.

Did my Beloved only touch me with his lips

I too, like the flute would burst out in melody."

WHINFIELD.

" Jism-i-ma juz wa muiz ast, ey pisar,

Gar tu mard'i z'in du chiz andar guzar,

War tu andar bugzari ikram-i-Haqq

Bugzaranad mar tura az nih tabaq."

JALAi.UDDIN RUMi.

"Pleasures of the flesh are as nuts and raisins, $\mathrm{O}$ son, If you are a man dispense with these two things; And if you dispense with them the goodness of God Will set you above the nine heavens." 
" Jism-1-pakan hamchu jan uftad saf Guftshan wa f'lishan wa zikrshan

Jumla jan mutlaq ayad nai nishan."

JaLALUDDin RUM!.

"The bodies of the righteous are as pure souls

Their words, their actions, their praises

Are all as a pure soul without spot or blemish."

" Jism jismana tawanad didanat

WIINFIEI.D.

- Dar khiyal arad gham wa khandidanat

Dil ki u basta gham wa khandidanast

Tu ma gu ki laiq an didan ast

An ki u basta gham wa khanda bud

$\mathrm{U}$ ba-din du 'ariyat zinda bud

Bagh-i-sabz-i-ishq k'u bi muntahast

Juz gham wa shadi dar u bas mowahast."

JALALUdin Rum.

"Can eye now behold Thee as truly Thou art?

Can heart Thy love picture and smiles e'en in part?

The heart that's a slave to a love or a smile

Can never be worthy to see thee awhile.

Engrossed he that's now with pleasure and pain

Can he by these accidents live o'er again?

Green pastures of love in their infinitude

More fruits yield than care and than beatitude."

" Jud bi ma jama'at kafaka min nashabin

REDHOUSE.

Hatta yura mujtadi jadwaka ma bhuta

Wa khuz nasibaka minhu qabla ratiatin

Mina 'zzamanl turyaka 'l'uda makhuta

Fa 'ddharu 'ankadu min 'an tastamirra

Halun takarrahta tilka 'lhala 'am shi'ta."

MaQquat of HaRik, chap. 38.

" lie bountiful with what thine hands have. been gathering that he who liegs for thy boon may be dumbfoundered,

And take thy share ere a stroke of fortune comes over thee that shows thee thy tree of life deprived of its fisliage,

For time is too fickle as in one state to endure whether thou delight in that state, or whether it be hateful."

STlingass.

"Jud wa la tamnun fa'inna 'lfaidata 'ilaika 'aidatun."

Arabic l'kovera.

"Do good and to not speak of it, and assuredly thy kindness will be recompensed to thee."

(litsturk).

"Jumbish har zarra bi asli khud ast

Har chi buwad mail-i-kase an shawad;

Jan wa dil az jazba'e mail wa hawas

Ham sifati dilbay wa janan shawad."

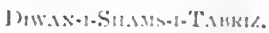


"The motion of every atom is towards its origin

A man comes to be the thing on which he is bent ;

By the attraction of yearning and fondness the soul and the heart

Assume the qualities of the Beloved and the soul of souls."

(Nicholson).

"Jumbish-i-khalq az qaza wa w'ada ast

Tizi dandan za suz m'ada ast

Aql awwal ra mudabbir aql duyam."

JALAI.UDDIN RUMI.

" Men are moved by God's decree and fixed ordinance, As sharp-set teeth are caused by heat of belly, 'Tis Primal Soul that dominates the Second Soul."

WhINFIELd.

"Jumbish-i-ma har dame khud ashahad'ast

K'u gawah zu'ljalal sarmad ast

Gardish sang-1-asya dar iztirab

Ashahad amad bar wujud jui ab

Ey birun az wahm wa qal wa qil-i-man

Khak bar farq-i-man wa tamsil-i-man."

JaLALUddin RUmi.

" Our every motion evcry moment testifies

For it proves the presence of the everlasting God,

So the revolution of the millstone so violent

Testifies to the existence of a stream of water.

O Thou who art above our conception and descriptions,

Dust be upon our heads and upon our similitudes of Thee."

WHINFIELD.

"Jumla alam mishawad har dam fana

Baz paida mi-numayad dar baqa,

Har nafs nau mishawad dunya wa ma

Bi-khabar az nau shudan andar baqa.

Umr hamchun jui nau nau mi-rasad

Mustamari mi-numayad dar jasad,

An za tizi mustamar shakl amadast,

Chun sharar kash tiz jumbani ba dast."

JalALUdDin Rumi.

" Every moment the world and we are renewed

Yet we are ignorant of this renewing for ever and aye.

Life like a stream of water is renewed and renewed

Though it wears the appearance of continuity in form,

That seeming continuity arises from its swift renewal

As when a single spark of fire is whirled round swiftly."

(WhiNEIELU).

"Jumla 'alam $z^{\prime}$ an ghaiyur amad ki haqq

Burd dar ghairat bar in 'alam sabaq

$\mathrm{U}$ chu jan ast wa jahan chun kalbud

Kalbud az jan pazirad nik wa bad."

JALALUDDiN RUmi. 
"The whole world is jealous for this cause

That God surpasseth the world in jealousy.

God is as a soul and the world is as a body

And bodies derive their gond and evil from souls."

WHINFIELD.

"Jumla dunya za kuhan ta ba nau

Chun guzaranda ast niarzad ba jau;

Mamlukate bihtar az in saz kun

Khushtar az in hujra dari baz kun."

ANWAR-1.SuheILr

" Or old, or new, so transient is this earth,

'Tis not in all one grain of barley worth, Prepare a better kingdom, then, than this, Forsake this cell, and ope the door to bliss."

Eastwick.

" Jumla haftad wa du millat dar tu ast

Wah ki ruze an bar arad az tu dast

Har ki u-ra barg an iman buad

Hamchu barg az bim an larzan buad."

JaLALUdDin RUMi.

"All the seventy and two heresies lurk in you, Have a care lest one day they prevail over you ;

$\mathrm{He}$ in whose breast the leaf of true faith is grown

Must tremble as a leaf from fear of such a catastrophe."

(WHINHELD).

"Jumla khalqan sakhra'e andisha and

Z'an sabab khasta dil wa gham pisha and."

Jalaluddis Rum.

" All crealures are enslaver to thought,

For this cause are they sad at heart and sorrowful."

WHINFIELD.

“Jumla nafsaha'e tu ey bad sanj

Kil zujan ast wa tarazu'e ranj

Manda tu dar arzu'e sang wa durr

Kil tihi gashta wa paimana pur."

Nizasit.

"All thy breaths, $\mathrm{O}$ thou weigher of wind, are but measuring loss and weighing sorrow,

II hile thou art remaining in eager search of stone and pearl,

Thy measure of wealth is become empty and the cup of thy life full."

Asiatic Miscellany.

"Jumla ra chun hast bar duzakh guzar

Jae shadi nist ba chandin khatar

Atishe dar pish dari, ey fagir

Hich khaufat nist az nar saqir?

Uqba dar rahast wa barat bas giran,

Nagzarad barat ba s'al digaran."

FARIDUUdin ATtar. 
"Since all mortals have to pass by hell, thou should'st not abandon thyself to joy in face of so great danger. Faqir, thou hast a fire before thee. Art thou not afraid of the consuming flame. Thou hast a mountain to traverse in the way and thy load is heavy: the efforts of others will not help thee to carry it."

" Jumla rindan chunki dar zindan rawand

Muttaqi wa zahid wa haqq khwan shawand

Chunki qudrat raft, kasid shud amal

Hin ki ta sarmaya nastanad ajal.

Qudratat sarmaya sud ast, hin,

Waqt qudratra nigahdar wa bibin."

JALALUDDIN RUM1.

" If all dissolute men were shut up in prison

They would all be temperate and devout and pious.

When power of choice is absent, actions are worthless

But beware lest death snatch away your capital,

Your power of choice is a capital yielding profit

Remember well the day of final account."

WHINFIELD.

"Juz ba khilwat-gah-i-Haqq aram nist."

JALALUDDIN Rumi.

" Except in the house of communion with God there is no peace."

"Juz ba shab, jalwa na bashad mah ra

Juz ba dard-1-dil, ma ju dil-khwah ra."

JALALUDDIN RUMI.

"Only in the night the moon shines,

Only in pain of heart seek the Beloved."

" Juz ba zidd ziddra hami natawan shinakht

Chun ba binad zakhm bishinasad nawakht;

La jurm dunya muqaddam amada ast

Ta bi dani qadr iqlim alast

Chun az in ja wa rihi, an ja rawi,

Dar shakr khana'e abad shakir shawi."

(Jalalludin RuniI).

"Opposites can only be know by opposites,

Only through a wound is a caress understood;

Certainly this world first comes into view,

That we may understand the value of that eternal world;

When you are released from this, you go to that;

In that eternal home of delight, you are grateful."

" Juzha bisyar wa dar waj maghz nai

Zauq bayad ta dihad ta'at bar

Maghz bayad ta dihad dana shajr

Dana'e bi maghz kai gardad nihal

Surat bi jan na bashad juz khiyal."

Jalal.uddix Rum. 
" Nuts in plenty but no kernel in any of them, Relish is needed for devotions to bear fruit, Kernels are needed that seeds may yicld trees, How can seeds without kernels become trees? Form without life is only a dreain."

WHINFIKL.D.

"Juz haqq, haqame ki hukmra shayad nist

Hasti ki za hukm-i-u birun ayad, nist

Har chiz ki hast anchunan mi-bayad,

Anchiz ki anchunan na mi bayad, nist."

Omar KhaYyam.

"What Lord is fit to rule but 'Truth?' Not one.

What creatures disobey His rule? Note one

All things that are, are such as He decrees

And naught is there beside beneath the sun."

WHINFIEI.D.

"Juzu duzakh ast in nafs-1-ma

Tabe'e kull darad juzuha."

JALALUDDIN RUMI.

Our earthly passions are a part of hell

And the parts always share the nature of the whole."

"Kabutare ki digar ashyan nakhwahad did

Qaza hami burdash ta ba sue dana wa dam." Gulistan, chap. 3

"The pigeon who his mate

Shall ne'er revisit, follows fate's deciee

Towards the net in blind security." (EAsTwick).

" Kada 'lfakru an yakuna kufran."

Proverb.

" Poverty borders on the denial of God."

Saying of Muhammad.

" Kada 'Ihalimu 'an yakunu nabian."

SAYing of MUнAMmad.

" The meek man is all but a prophet."

(EAstivick).

"Kafa bi taghaiyuri zzamani naziran."

Gulistan.

"Change of time is a sufficient admonisher."

(Platest).

“ Kafara 'lladhina qalu 'inna 'llaha huwa 'l Masihu 'bnu Maryama qul faman yamliku mina 'llahi shai'an in 'arada 'an yuhlika '1 Masiha 'bna Maryama wa 'ummahu wa man fl'l'ardhi jami'an."

KORAN, chap. 5. V.?

"Infidels assuredly are they who say "Verily God is the Messiah, Ibn Maryam (son of Mary)!'/(Say 'Who then could have any power over God if He chose to destroy the Messiah, Ibn Maryam, and his mother, and all who are on the earth together?" " (RoDwriL). 
"Kaflran karand dar ni'mat jafa

Baz dar duzakh nida ishan 'rabbanal'

Hast zindan sum'a duzd la'im

K'andar an zakir shawad haqq ra muqim

Chun ibadat buwad maqsud az bashar

Shud 'ibadatgah gardankash saqar."

JAlALUddin Rumi.

" Infidels when enjoying prosperity do wrong

When they are in hell, they cry ' $O$ our Lord!'

The prison is the hermitage of the wicked thief

For when he is there, he is ever crying to God.

Whereas the object of man's being is to worship God,

Hell is ordained as a place of worship for the proud."

- Kah na bud u ki bibadi parid,

WHINFIELD.

Ab na bud u ki bisarma fusurd,

Shana na bud u ki bi mui shikast,

Dana na bud u ki zaminash fushurd,

Ganj-i-zari bud darin khakdan

K'u du jahanra bi jaui mishumurd,

Qalib-i-khaki sue khaki flgand,

Jan wa khirad sue samawat burd;

Saf bar amikhta ba durd mai,

Ba sar-1-kham raft wa juda gasht durd,

Jan-i-duyamra ki na danand khalq

W'allah guyam ki bijanan supurd."

DiWan-1-Shams-I-TAbriz.

" He was not chaff which flew on the wind,

He was not water which froze in winter,

He was not a conb which was broken with a hair,

He was not a seed with the earth crushed,

He was a treasure of gold in this dust-pit,

For he valued the two worlds at a barley corn,

The earthly frame he flung to the earth,

Soul and intellect he bore to heaven,

The pure elixir mingled with the wine-dregs,

Came to the jar's surface, and the lees settled apart.

The second soul, which the vulgar know not,

I protest by God that he surrendered to the Beloved."

(Nicholson).

" Kaifa 'lhuda baghair b'airin wa 'lambadhu m'a faqadi 'ttawatir."

ABU'L 'ALA.

"How can camel-driving be done without a camel,

Or the bow be twanged unless it first be strung?"

(D. S. Margoliou'th).

" Kai sitara hajatasti, ey zalil,

Ki buad ba nur khurshaid u dalil?

Hich mah wa akhtari hajat na bud

Ki bud bar aftab-i-haqq shahud." .

JALALUDDIN RUMi. 
"What need were there of stars, O humble one, To one who was guided by the light of the sun, Neither moon nor planets would he needed, By one who saw directly the sun of the truth."

(WHINFIE1.D.

"Kaj rawan-ra dihand khirmanha

Barg kahi ba-rastan na dihand Magasan ra dihand shakar wa kand

Ba humayan juz ustukhwan na dihand."

ANWAR.I.SUHehl.

" The devious meet with ample measures

Straight-goers get but blades of grass ;

Flies feast on sweets and candied treasures And glorious Humas filthy bones amass."

EASTIVICK.

" Kalid dar ganj-i-maqsud sabr ast

Dar basta an kas ki bikashud sabr ast."

ANWAR-1-SvHEILl.

" Patience the key that opes the treasury

Of wished-for things, unlocks each closed-up way."

EASTwick.

" Kalld dar-i-duzakh ast an namaz

Ki dar chashm mardum guzari daraz." BOSTAN OF S'ADI, chap. 5.

"The key of hell's door is that prayer

Which thou, in men's ejes, makest long." (CLARKE).

"Kalid-i-qadr nist dar dast-i-kas

Tawana'e mutlaq khuda ast wa bas." Bostan of S'Ad1, chap. 8.

"The key of destiny is in no man's hand,

God is absolutely powerful, and that is enough."

(CLARKE).

"Kalimatan tayyibatan ka shajaratin tayyibatin 'asluha thabitun wa far'uha fl 'ssama'i."

KorAN, chap. 14.

"A good work is as a good tree; its root firmly fixed and its branches in the heaven."

(RODWEL1.).

“ Kallimi 'nnasa 'ala qadri 'uquilihim." Gulistan, chap. 5.

"Spcak to people according to the measure of their understandings." PI.ATTS.

"Kalukh andazra padash sang ast."

ANWAR-1.SUheIL.

"Those who throw clods are answered with a stone."

EAstivick. 
" Kalukh ar che uftada bashad birah

Na bini ki dar wai kunad kas nigah

Wa gar khurda'e zar za dandan-i-kaz

Bi uftad, bi sham'aash bijuyand baz."

Bostan of S'ADI, chap. 6.

"A clod though it be fallen on the road,

Thou seest not that anyone looks at it.

But if a fragment of gold from the teeth of the scissors

Falls, - they will search again and again for it with a candle.'

(ClaRkE).

"Kam 'ahlakna qablahum min qarnin, hal tuhissu minhum min 'ahadin au tasma'u lahum rikza."

Koran, chap. rg.

" How many generations have we destroyed before them?

Canst thou search out one of them? Or canst thou hear a whisper from them?"

(RODWELI.).

" Kamile gar khak girad zar shawad

Naqis ar zar burd khakistar shawad.

Chun za qabul-i-haqq bud an mard rast

Dast-i-u dar karha dast-i-khudast.

Dast-i-naqis dast Shaitan ast wa div

Z'anki andar dam taklifast wa riv."

JALALUDDIN RUMI.

" If a saint handles earth, it becomes gold

If a sinner handles gold, it turns to dust,

Whereas the saint is well-pleasing to God,

In his actions his hand is the hand of God.

But the sinner's hand is the hand of Satan and demons,

Because he is ensnared in falsity and fraud." (Whinfield).

" Kam ma bash az darakhte siyah fikan

Har ki sangat zanad samar bakhshash."

HAFIZ.

"Be not less than the tree umbrageous grown And fruit on him who flings a stone bestow."

Bicknell.

" Karimanra ba dast andar daram nist

Daram daran-i-alamra karm nist."

Gulistan, chap. 7 .

"The merciful are ever moneyless,

Hard-hearted they who have the power to bless."

(EASTWICK).

" Karm bin wa lutf khudawandgar

Gunah banda kardast, u sharmsar!"

Gulistan, Preface.

" God's condescension and Ilis mercy see His servant sinneth and ashamed is He." EAsTwick. 
“ Kar-í-tu tabdll ayan wa 'ata

Kar-i-ma sahwast wa nisian wa khata

Sahw wa nisian ra mubaddal kun ba $1 \mathrm{~mm}$

Man hama jahlam mara dih sabr wa hilm.

Ey ki khak shura tu nan kuni,

W'ey ki nan murdara tu jan kuni,

Mekuni juzu zamin ra asman

Me afzal dar zamin az akhtaran."

Jalaluduin RUMi.

"Thy business is changing things and bestowing favours, My business is mistakes and forgetfulness and error, Change my mistakes and forget/ulness to knowledge

I am altogether vilc; make me temperate and meek.

O thou that convertest salt earth into bread

And bread again into the life of men,

Thou makest some earth-born men as heaven

And multipliest heaven-born saints on earth." (WHINFIELD).

"Kar kun dar kargah bashad nihan,

Tu biru dar kargah binash ayan;

Kar chun bar karkun parda tanid

Kharij-i-an kar natawanash did."

JALAI.UDDIN RUMI.

" The Worker is hidden in the workshop,

Enter the workshop and lehold him face to face;

Since a veil is drawn over the Worker by his work,

Apart from His work you cannot see llim." (Nicholson).

" Kase ba gardan-i-maqsud dast khalqa kunad

Ki pish tir bala ha sipar tawanad buwad;

$\mathrm{Ba}$ arzu wa hawas bar ni-ayad in ma'na

Ba ab-i-dida wa khun-1-jigar tawanad buwad." ANwar-1-Suhtil.t.

"He may embrace his wish's neck, who will

Shield-like, confront the darts of coming ill ;

This will not from mere longing hopes arisc

'Tis won by efforts stern and tearful eyes." EAsTwick.

"Kase ki rue tawakkul na did, hich na did

Kase ki az qina 'at na yaft hich na yaft."

ANWAR:1-SUHEILI.

" Who trust in God has ne'er beheld, has ne'er discovered aught,

Contentments store who ne'er has found, his findings are but naught."

"Kas na ayad ba khana-e-derwish

Eastwick.

Kl khiraj-i-zamin wa bagh bi dih.

Ya batashwish-i-gussa razl shu

Ya jigarband pish-i-zagh binih."

Gulistan, chap. I.

" None in the poor man's hut demand

Tax on his garden or his land.

Be thou content with toil and woe

Or with thy entrails feed the crow." (EAstwick). 
"Kas na guyad ki dugh-i-man tursh ast."

Persian Proverb.

"Nobody calls his own butter-milk sour."

“ Kas ra pish-i-parda'e qaza rah na shud, W'az sirr-i-qadr hich kas agah na shud, Haftad wa du sal flkr kardam shab wa ruz Ma'lum na gasht wa qissa kutah na shud."

Omar Khavyam.

"What eye can pierce the veil of God's decrees?

Or read the riddle of earth's clestinies?

Pondered have I for years threescore and twelve

And can but say these things are mysteries." Whinfield.

"Kas ni ayad bazir-i-saya-i-bum

War huma az jahan shawad m'adum."

Gulistan, chap. I.

"What though the phœnix from the world take flight

'Neath the owl's shadow none will ere alight."

"Kas nabinad ki tishnagan-i-Hijaz

(EASTWICK).

Balab-i-ab-i-shur gird ayand

Har kuja chashma'e buwad shirin

Mardum wa murgh wa mur gird ayand."

Gulistan, chap. I.

"None sees the Hijaz pilgrims faint with thirst

Crowd to the margin of the brimy sea :

Where'er the fountains of sweet water burst

Their way : there men and birds and ants will be."

" Kaukab-i-bakht chu tali 'shawad az auj-i-murad

(EASTWICK).

An chi maqsud bud zud muyassar gardad,

Madad tali' agar nist, maranjan khudra

Ki agar rui sue bahr nihi, bar gardad."

ANWAR-1-SUhelli.

"When o'er hope's horizon rises fortune's brightly shining star, How swiftly every wish is won!

But if fortune does not aid thee, it will all thy efforts mar, Turn to the sea, 'twill from thee run."

"Kazhdum ra guftand 'chira ba zamistan birim na mi-ai?' Guft 'Batabistan chi hurmatast ki ba zamistan niz biyayam?"

Gulistan, chap. 7 .

"They said to a scorpion 'Why dost thou not come abroad in winter?" He replied 'What respect is shown to me in summer, that I should show myself in winter also ?"

(EASTWICK).

"Khabisra chu ta"hhad kuni wa binawazi

Bi daulat-i-tu gunah mikunand b'ambazi."

Gulistan, chap. 8.

"When thou to base men giv'st encouragement

Thou shar'st their sins since thou them aid hast lent."

(EASTWICK). 
- Khajil ankas kl raft wa kar nasakht

Kus-1-rihlat zadand wa bar nasakht."

Gulistan (Preface).

"Shame on the dull departed dead

Whose task is left unfinished

In vain for them the drum was beat

Which warns us of man's last retreat." (EAsTwICK).

" Khakistar agarchi nisbate "ala darad az an ki atish jauhar alu ast wa lekin chun ba nafs-i-khud hunare na darad ba khak barabar ast."

Gulistan, chap. 8.

"Ashes though akin to that which is exalted, inasmuch as fire is essentially nuble, yet not possessing any intrinsic worth are no better than dirt."

(EASTIVICK).

" Khal 'amran wa ma akhtara."

ABU'L 'Al.A.

"Leave a man to his choice."

D. S. Margolioutil.

" Khalaqnakum min turabin, thumma min nutfatin thumma min alaqatin, thumma min mudhghatin mukhalliqatin linubayyina lakum wa nuqirru fllarhami ma nashau lla 'ajalin musamma, thumma nukhrijukum tiflan, thumma litablughu 'ashuddakum, wa minkum man yuta waffa wa min yuraddu "ila 'ardhali 'lumuri."

Koran, chap. 22.

"We have created you of dust, then of the moist germs o? life, then of clots of blood, then of pieces of flesh shapen, that we might give you proofs of our power. And we cause one sex or the other at Our pleasure to abide in the womb until the appointed time ; then we bring you forth infants; then permit you to reach your age of strength and one of you dieth and another of you liveth on to abject age."

(RODUELL).

“Khalaqa sab'a samawatin tibaqan, ma tara fl khalqi 'rrahmani min tafawutin, fa'rji ' 1 basara, hal tara min futurin, thumma 'rji'i 'lbasara karrataini yanqalib llaika 'lbasaru khasi'an wa huwa hasir."

KORAx, chap. 67.

"He created seven heavens one above another. No defect canst thou see in the creation of the God of mercy. Repeat the gaze; Seest thou a single flaw? Then twice more repeat the gaze: thy gaze returns to thee dull and wearied."

(RODIVELL).

" Khalq chu murghabian zada za darya'ejan

Kai kunad in ja maqam murgh k'az in bahr khast?

Balki badarya durr em, jumla dar u hazir em

Warna za darya'e jan mauj-1-payapi chirast?"

DIWAN-1-SHAMS-I-TABRIZ. 
" Mankind like waterfowl are sprung from the sea, the sea of soul, Risen from that sea, why should the bird make here his home? Nay, we are pearls in that sea, therein we all abide, Else why does wave follow wave from the sea of soul."

Nicholson.

" Khalq diwanand wa shahwat silsila

Mik'ashad ishan sue dukan wa ghala

Hast in zanjir az khauf wa wala

$\mathrm{Tu}$ mabin in khalq ra bi silsila;

Mikashanadshan sue kisht wa shikar

Mikashanadshan sue kanha wa bahar."

Jalat.uddin RUMr.

" Men are as demons and lust of wealth their chain,

Which drags them forth to toil in shop and field;

This chain is made of their fears and anxieties,

Deem not that these men have no chains upon thein.

It causes them to engage in labour and the chase,

It forces them to toil in mines and on the sea."

WHINFIELD.

" Khana'e div ast dilha hama

Kam pazir az div mardam damdama."

JAI.ALUdDin Rumi.

"All hearts are the abodes of devils

Be not deceived by devil-men."

"Kharabi za bi dad binad jahan

Chu bustan khurram za bad-1-khazan."

PandNaina of S'Adi.

"The world suffers destruction from injustice As a delightful garden by the wind of autumn."

(GLADWIN).

"Khatama 'llahu 'ala qulubihim wa'ala sam'ihim wa'ala 'absarihim ghishawatun wa lahum 'adhabun "adhim."

KorAN, chap. 2.

"Upon their hearts and their ears hath God set a seal, and over their eyes is a covering (and for them a severe punishment.") (RoDweLL).

" Khatim-i-tu in dil ast, wa hushdar

Ta na gardad div ra khatim shikar."

JaLALUdDin Rum.

"Your heart is as Solomon's signet ; take care That is falls nut a prey to demons."

(WHINFIELD).

"Khilaf-i-ra'e-i-sultan ra'e justan

Ba khun-i-khwish bayad dast shustan

Agar shah ruzra guyad shabast in,

Babayad guft "inak mah wa parwin."

Gulistan, chap. I. 
"Opinions differing from the king's to have

Is your own hands in your own blood to lave;

Should he affirm the day to be the night,

Say you behold the moon and pleiads' light."

(EAstwick).

"Khil'ate bas fakhir amad 'aibash kutahist."

JAMI.

"Life is a very splendid robe ; its faults is brevity."

" Khilqat tifl az chi andar nih mah ast?

(Nicholsox).

Z'anki tadrij az sunnatha'e shah ast

Na chu tu, ey kham, k'aknun takhti

Tifli, wa khud-ra tu sheikhe sakhti."

Jalaluddix Rumi.

"Why does the formation of an infant take nine months,

Because God's method is to work by slow degrees.

Not hurrying on like you, $\mathrm{O}$ raw one,

Who claim to be a Shaikh whilst yet only a child."

" Khuda'erast musallam buzurgi wa 'ltaf

(WHINFIELD).

Ki jurm binad wa nan bar qarar mi darad." Gulistas, chap. I.

"Grandeur and merciful kindness are universally acknowledged to belong tu God,

Since He sees a fault and yet continues the means of sustenance intact."

" Khud gharibe dar jahan chun shams nist

Shams-i-jan baqist kura ams nist."

(Platts).

"In the world there is nought so wondrous as the sun, But the Sun of the soul sets not and has no yesterday."

"Khud sana guftan za man tark-i-sana'st Ka'in dalil-i-hasti wa hasti khata'st."

(WhINFIELD).

Jalaledin Rum.

"Tis blasphemy to praise Him": I proclaim Myself extant and "self" is mortal shame."

"Khuliqa'I'insanu dhaifa."

(NiCHOLSON).

" Man was created weak."

KORAN, chap. 4.

(RoDWEl.1.).

"Khuliqa 'l'insanu min "ajalin."

KukAx, chap. 21.

" Man is made up of precipitation."

(KONWELA.).

"Khusha tafarruj-i-Nawruz, khasse dar Shiraz

Ki bar kanad dil-i-mard-i-musaflr az watanash."

SA'DI.

" l'leasant is the New Vear's outing, especially in Shiraz

llhich turns aside the heart of the traveller from lis natire l:md."

(1.. (i. likumine). 
" Khushat az jam-i-wasl-i-dilbaran mai Wale hastash khamar-i-hijar dar pai."

ANWAR-I-SUHEILI.

"From the goblet of union with loved ones how sweet is the wine that is quaffed,

But the headache of parting soon follows, soon mars the delight of the draught."

(EASTWICK).

"Khushat zir-i-mughilan birah-i-badia khuft Shab-i-rahil wali tark-i-jan babayad guft."

GUi.lstan, chap. 2.

"Sweet is slumber in the desert under the acacia tree

On the night when friends are marching, but it bodeth death to thee."

"Khush buwad gar mahakk-i-tajruba bar ayad

(EASTWICK).

Ta siyah rui shawad har ki darughash bashad." ANwar-1-Suheil.

"How gond, if trial such a touchstone were

That liars would a blackened visage wear."

"Khwaja dar band-i-naqsh-i-aiwan ast

EASTWICK. Khana az pai past wa wiran ast."

Gulistan, chap. 6.

" The master's bent on garnishing

His house, which sapped, is falling in." (EAstwick).

“ K'ist dar gush ki u me shinawad awazam,

Ya kudamast sukhan mikunad andar dihanam,

K'ist dar dida ki az dida birun minigarad,

Ya chi janast (nagui) ki manash pairanham?"

Diwan-I-Shams-I-TABRiz.

"Who is he in my ear that hearkens to my voice,

Or who is he that utters words in my mouth?

Who is he in mine eye that looks out of mine eye

Or what is the soul-wilt thou not say-of which I am the garment?"

(NICHOLSON).

" Kuh'ra dida, na dida kan ba kuh."

JALALUDDIN RUMi.

"You have seen the mountain, not the mine within the mountain."

" Kudaki ku biaql pir buwad

Nizd-i-ahl-i-khirad kabir buwad."

Gulistan, chap. r.

"The boy who is an old man in point of wisdom

Is held great in the estimation of the wise." (PLATTS).

" Kudam dana faru raft dar zamin ki narust

Chira ba dana'e insanat in guman bashad?"

Diwan-I-Shams-I-TABriz.

"What seed went down into the earth but it grew, Why this doubt of thine as regards the seed of man?"

(NiCHOLSON). 
" Kuflta 'adhan ya man ta uddu mahasini

"Alaniyati hadha wa lam tadri batini."

Gulistan, chap. 2.

"Thou hast been made sufficient for doing harm, $\mathrm{O}$ thou who enumeratest my good qualities,

This is my outward conduct ; thou knowest not my heart."

(Platts).

"Kuhan kharqa khwish pirastan

Bih az jama'e 'ariyat khwastan."

Gulistan, chap. 8.

"Better patch up one's own old garment than

Borrow the rainent of another man."

EASTwICK.

" Kujast ahl-l-dill ta kunad dallalat khair

Ki ma ba dust naburdem rah bahich tariq."

Hafiz, Ode, 350.

"Where can I find a man devout my steps towards good to bend, I ask, for not by any path have I attained my friend." (BICk.Nei.l.).

“ Kulla 'insanin 'alzamnahu ta'irahu fl 'unuqihi wa nukhriju lahu yauma 'lqiyamati kitaban yalqahu manshura. 'Iqra kitabaka kafa binafsika 'lyauma alaika hasiba."

KORAN, chap. 17.

" Every man's fate have we fastened about his neck, and on the day of resurrection will we bring forth to him a Book which shall be proffered to him wide open : "Read thy book : there needeth none but thyself to make out an account against thee this day."

(KODWELL).

"Kullu 'amrin dhi balin lam yubda bibism'illahi fahuwa abtarun."

Savisg of Muhammad.

"Every work of import that is not begun in the name of God is abortive."

" Kullu kuthrin ila qullin maghabatahu wa kullu nazin ila linin, wa.in haja."

MaqAMAT OF HaRiRi, chap. 3 .

" Every mickle comes to be a mite, and meek grows every stiff-necked one, rage he, as he may." STEINGASS.

"Kullu man alaiha fanin wa yabqa wajhu rabbika dhu'ljalali wa'l'ikram."

KorAs, chap. 55.

" All on the earth passeth away, but the face of thy Lord ahideth in its majesty" and glory."

(RODWELL).

" Kullu 'mrin bima kasaba rahin."

KORAN, chap. 52.

" I'ledged to God is every man for his actions."

" Kullu nafsin dha'iqatu 'Imaut."

"Every soul shall taste of death."

(RODWELL).

Koras, chap. 21.

(Rodwell.). 
"Kullun laisa ya'du himamahu wa ma l'marin 'amma qadha 'llahu mazhalu."

IBRAHIM IBN KUNAIF.

"None outruns by a span his doom, And refuge from God's decree nor was, nor will ever be."
C. J. Lyall.

"Kullu shai'an haliqun "illa wajhahu."

KORAN, chap. 28. . $\gamma, E \%$

" Everything shall perish except His face." (Rorwell).

"Kullu shai'an hatta akhika mita'un

Wa biqadrin tafarriqun wa ijtama'un."

(ANON).

" Everything down to thy brother is 'furniture;' and fate rules both separation and gathering." $\quad$ D. S. Margoliouth.

"Kullu shaian yabdu saghiran thumma yakburu illa 'lmusibata fa 'innahaha tabdu kabiratan thumma tasghuru."

Lataif ul MUluk.

" Everything is small at its beginning and then increases, except trouble which is great at its beginning and then decreases."

"Kullu shai'an yarj'au 'ila 'aslihi."

Arabic Proverb.

" Everything returns to its source."

" Kunj-j-'uzlat ki tilismat-i-aja'ib darad

Fath-i-an dar nazar-i-himmat-i-darwishan-ast."

HAFiz.

"The talisman of magic might hid in some ruin's lonely site,

Emerges from its ancient night at the mild glance of darveshes."

BiCKNELl.

"Kuntu kanzan makhfian fa'ahbabtu 'an 'ur'afa, fakhalaqtu 'lkhalqa lakai 'urafa."

Saying of Muhamiad.

"I was a hidden treasure and I desired to be known, so I created the creation in order that I might be known."

" Kuntu kanzan makhfian shanau

Jauhar-i-khud gum ma kun izhar shau

Jauhar sidqat khafl shud dar darugh,

Hamchu ta'am raughan andar ta'am dugh,

An darughat, in tan fani buwad

Rastast an jan rabbani buwad

Salha in dugh-i-tan paida wa fash

Raughan jan andar " fani wa lash."

JaLALedir Rum. 
" Read 'I was a hidden treasure and desired to be known

Hide not the hidden treasure but disclose it ;

Your true treasure is hidden under a false one,

Just as butter is hidden within the substance of milk,

The false one is this transitory body of yours,

The true one your divine soul.

Long time this milk is exposed to view

And the soul's butter is hidden and of no account."

"Kununat ki imkan-i-guftar hast

(WHINFIELD).

Bigu ey biradar ba lutf wa khushi;

Ki farda chu paiyik-i-ajal dar rasad

Ba hukm-1-zarurat zaban dar kashi."

Gulistan (Preface).

"Now that the power of utterance is thine, Speak, O my brother ! kindly, happily, To-morrow's message bids thee life resign, Then art thou silent of necessity."

(EASTwICK).

"Kunun ba khirad bayad ambaz gasht

Ki farda na manad rah-i-baz gasht."

Bostan of S'AdI, chap. 9.

"Now it is proper to become a partner with wisdom For to-morrow the path of returning remains not."

(Clarke).

"Kunan kush k'ab az kamar dar guzasht

Na waqte ki sailabat az sar guzasht

Kununat ki chashm ast, ashke bibar

Zaban dar dihan ast, uzre byar."

BOSTAN'OF S'ADI, chap. 9.

"Strive now when the water possesses only thy waist,

Not when the torrent passes over thy head.

Now when thou hast an eye, rain a tear,

Thy tongue is in thy mouth, bring forth excuse for sin."

(Clarke).

"Kunun waqt-i-tukhm ast agar parwari

Gar ummed dari ki khirman bari ;

Garat chashm-i-aql ast wa tadbir-i-gur

Kunun kun ki chashmat nakhurdast mur."

BOSTAN OF S'ADI, chap. 9.

"If thou art solicious now is the seed-time

If thou hast hope that thou mayest take the harvest,

If thou hast an eye to wisdom and deliberation as to the grave, Act now when the ant of the grave has not devoured thine eye."

"Kura jama pak ast wa sirat palid

(CLARKE).

Dar duzakhashra nabayad kalid;

Dar in astan ujuz wa miskiniyat

Bih az ta'at wa khwishtan biniyat."

(BOSTAN OF SA'Dt). 
" He whose outward vesture is pure but whose morals are corrupt, to such a one the gates of hell will need no key,

At God's threshhold, impotence and distress will more avail thee than obedience and self-approval."

(AsIATIC JourNal).

" Kus-i-rihlat bikuft dast-i-ajal

Ey du chashmam ! wida'-sar bikunid

Ey kef-1-dast wa sa id wa bazu

Hama taudi' yakdigar bikunid ;

Bar man uftada dushman kam,

Akhir ey dustan guzar bikunid;

Ruzgaram bashad ba nadani,

Man na kardam, shuma hazar blkunid."

Gulistan, chap. I.

" Death's hand has struck the signal drum,

Eyes ! now obey your parting knell,

Hands, wrists and arms, all members come

And bid a mutual long farewell !

Hope's foe, death, has me seized at last ;

Once more, $\mathrm{O}$ friends before me move,

In folly has my time been past,

May my regrets your warning prove."

(EASTWICK).

" Kuza'e chashm harisan pur na shud

Ta sadf qani' na shud pur durr na shud,

Har kura jama za ishqi chak shud

U za hirs wa 'aib kulli pak shud."

Jalaludin Rum.

" The pitcher of the desire of the covetous never fills,

The oyster-shell fills not with pearls, till it is content,

Only he whose garment is rent by the violence of love

Is wholly pure from covetousness and sin." (WHINFIRLD).

“ La'amla'anna jahannama min '1jinnati wa 'nnasi 'ajmain."

"I will surely fill hell with Djinn and men together." (RoDweLL)

“ La 'amruka ma tughni 'lmaghani wa la 'lghana,

Idha sakana 'Imuthri ulththara wa thawa bihi,

Fajud fi maradhi 'llahi b'ilmall radhiyan,

Bima taqtani min 'ajrihi wa thawabihi,

Wamaththil l'ainaika 'lhimam wa waq'ahu,

Wa raw'atan malqahu wa mat'ama sabihi." Maqamat of Hariri.

" By thy life! mansions and wealth will not avail when the rich man dwells in the ground and abides in it ;

So be liberal with thy wealth in things pleasing to God, content with what thou gainest of $\mathrm{His}$ hire and reward.

And figure to thy mind Death and His stroke and the terror of His meeting, and the taste of his wormwood cup." Chenery. 
" La baraka 'llahu fl 'ddunya idha 'nqata'at Asbab dunyaka min asbabi dunyana."

HaMASA。

" God grant no blessing on our world now that it is no longer thine."

D. S. Margoliouth.

" Lab bar lab-1-kuza burdam az ghayat-i-az

Ta zu talabam wasta-e-umr-i-daraz

Lab bar lab-1-man nihad wa miguft baraz

Mal khur ki badin jahan na ml a'l baz."

OMAR KHAYYaM.

"I put my lips to the cup for I did yearn

The means of gaining length of days to learn,

It leaned its lip to mine and whispered low,

'Drink for once gone, you never will return.',

WHINFIELD.

" Lab khushk mazlum-ra gu "bikhand

Ki dandan-1-zalim bikhwahand kand." BOSTAN of S'ADI, chap. 1.

"Say to the withered lip of the oppressed one,- "laugh !

Because they will dig out the teeth of the tyrant." (CLARKE).

"La Ikraha fl'ddina, qad tabayyana 'rrushdu mina 'lghayyi fa man yakfur bi'ttaghuti wa yumin bi'llahi faqadi 'stamsaka bi' urwati 'lwuthqa la inflsama laha wa 'llabu sami'un 'alim."

Koras, chap. 2.

"Let there be no compulsion in religion.) Now is the right way made distinct from error; whoever therefore denieth Taghoot and believeth in God, hath taken hold on a strong handle that hath no flaw therein: and God is He who heareth, knoweth."

(RODWELL).

"Laisa 'Ibirra 'an tuwallu wujuhakum qibala 'Imashriqi wa 'Imaghribi wa lakinna 'lbirra man amana bi'llahi wa 'lyaumi 'lakhirl wa 'Imala'ikatihi wa 'lkitabi wa 'Inabbiyyin wa'ata Imala ala hubbihi dhul'lqurba wa 'lyatami wa 'lmasakin wa 'bna 'ssabil wa 'ssa'ilin."

Koran, chap. 2.

"There is no piety in turning your faces towards the east or the west, but he is pious who believeth in God and the last day, and the angels and the Scriptures and the prophets; who for the love of God disburseth his wealth to his kindred, and to the orphans, and the needy and the wayfarer, and those who ask."

RODWELL.

"Laisa lil'insani illa ma sa'a."

KORAN, chap. 53 .

"Nothing shall be reckoned to a man but that for which he hath striven."

RODWELI..

"Laisa li ma 'usa'u in fata au 'ahzanu in hawala 'zzamu 'btizaza

Ghaira 'anni 'abitu khilwan mina 'lhammi wa nafsi 'ani 'l'asa mun haza."

MAQAMAT OF HARIRI (chap. 27). 
" There is nothing mine that I miss when it is gone, or fret about when the vicissitudes of time rob me thereof;

Save that I pass my night free from concern, and my mind has severed partnership with sorrow."

(STEINGiASS).

'Lait sh'ari wa ain mini lait, in lauan wa laitan "ana." ABu Zubaid.

"Would I knew! yet what use is 'would that?' truly 'Ohs' and "woulds' are only trouble." D. S. MARGoliouTH.

“Lakini 'lladhina 'ttaqu rabbahum lahum ghurafun min fauqiha ghurafun mabniyyatun tajri min tahtiha 'nnaharu w'ada 'llahi, la yukhlifu 'llahu 'lmi'ad." KORAN, chap. 39.

" But for those who fear their Lord are storied pavilions, beneath which shall the rivers flow: it is the promise of God. God will not fail a promise."

RODWELL.

"Lakinnahu ma tashinu 'lhurra muji'atun

F'almisku yushaku wa'lkafuru maqtutu

Wa talama 'usila 'lyaqutu jamra ghadan,

Thumma 'ntafa 'ljamru, wa'lyaqutu yaqutu."

Maqamat of Hariri, chap. 47.

"But no distress brings disgrace on the high-minded man; camphor and musk though pounded, spread fragrance.

The ruby is often tried in Ghada-fire's fiercest glow ; the fire abates, but the ruby still remains ruby."

STEINGASS.

"Lakum dinukum wa li dini."

Koran, chap. rog. $\mathrm{V} \cdot 6$

"To you your religion, to me my religion."

"L'al ra gar muhr na bud bak nest

"Ishq dar darya-e-gham ghamnak nest."

JaLALUddin Rumi.

" Though the ruby has no stamp, what matters it?

Love is fearless in the midst of the sea of fear."

WhINFIELD.

"Lan tanalu "birra hatta tunflqu mimma tuhibbuna wa ma tunflqu min shai'an fa'inna 'llaha bihí 'alim.

KORAN, chip. 3.

"Ye shall by no means attain to goodness till ye expend that which ye love as alms; and whatsoever ye so expend, then of a truth God knoweth it."

"Lan yaflahu qaumun asnadu amrhum ila 'amratin."

Saving of Muhammad

"Never shall a nation prosper that has given a woman charge of its affairs."

D. S. Margoliouti. 
"Lan yahlaka 'amrun 'arafa qadrahu."

Arabic ProverR.

"No man ever conies to grief who knows his own place."

D. S. Margoliouth.

"Lan yanala 'llaha luhumuha wa la dima'uha wa lakin yanaluhu 'ttaqwa minkum kadhalika sakhkharaha lakum litukabbiru 'llaha ala ma hadakum."

KORAN, chap. 22.

"By no means can their flesh" reach unto God, neither their blood, but piety on your part reacheth Him. Thus hath $\mathrm{He}$ subjected them to you, that ye might magnify God for His guidance." RoDwell.

"Lana 'a'maluna wa lakum 'a'malukum, salamun 'alaikum la nabtaghi 'Ijahilln."

KORAN, chap. 28.

"Our works for us and your works for you! Peace be on you. We are not in quest of fools."

(RODWELL).

"Laqad karammna bani Adama wa hamalnahum fl'lbarri wa 'Ibahri."

KORAN (chap. I7).

"We have honoured the children of Adam and by land and by sea have we carried them."

(RODWELL).

"Laqad katabna fl'zzaburi min ba'di dhdhikri anna 'lardha yarithuha "ibadiya 'ssalihun."

KORAN, chap. 2I.

"We have written in the Psalms that ' $m y$ servants the righteous shall inherit the earth."

RODWELL.

"Laqad khalaqna '1'insana fl kabad."

- Koran, chap. go.

"Verily we have created man in trouble."

RODWELL.

"Laqad khalaqna 'linsana fl 'ahsanl taqwim, thumma radadnahu 'asfala saflinn."

(KORAN, chap. 95).

"Verily of goodliest fabric have we created man, then brought him down to be the lowest of the low."

(RONWELL).

"Laqad kunta fl ghaflatin min hadha fakashafna 'anka ghita"k fabasaruka 'lyauma hadid."

KORAN, chap. 50 .

"Of this day (the judgment) didst thou assuredly live in heedlessness; therefore have we stripped off thy veil from thee and thy sight this day is sharp."

(RoDWELL).

"La rahbaniyata fi'llslaml."

Saying of Muhammad.

"There is no monkery in Islam."

* i.e., Of animals. 
"La salata tamma illa bi'lhudhuri."

Saving of Muhammed.

"Prayer is not complete with concentration of mind."

" La tabki 'ilfan na'a wa la dara wa dur ma'a 'ddahri kaifama dara W'attakidhi 'nnasa kullahum sakanan wa maththali 'lardha kullaha dara

W'asbir 'ala khulqi man tu 'ashiruhu wa darihi f'allabibu man dara."

MAQqMAT OF HARIRI, (28).

"Weep not for a friend that is distant, nor for an abode, but turn thyself about with fortune as it turns about,

Reckon thou all mankind thy dwelling-place, and fancy all the earth thy home,

Forbear with the ways of him with whom thou dealest and humour him for it is the wise that humours."

(STEINGASS).

" La tahmil ala yaumika hamma sanatika."

"Load not upon thy day the burden of thy year." Prov.

"La tahsab al majda tamran anta akaluhu

Lan tadriku 'l majda hatta tal'aqu 'ssabira."

(ANON).

“ Think not glory a date which thou can'st eat; thou shalt not attain to glory till thou have licked wormwood." $\quad$ D. S. MARGOLIOUTH.

"La tahsabanna 'llaha ghaflan amma y'amalu 'dhdhalimun 'innama yu akhkiruhum liyaumin tashkhasu fihl 'lbsaru, muhti'ina muqni'i ru'usihim la yartaddu ilaihim tarfuhum wa 'afldatuhum hawa'un."

KORAN, chap. 14.

"Think not that God is regardless of the deeds of the wicked, He only respiteth them to the day on which all eyes shall stare up with terror; they hasten forward in fear; their heads upraised in supplication; their looks riveted ; and their hearts a blank."

RODWELL.

"Lataif-i-sukhan az sina tukhm-i-kin baburd

Zaban-i-rifq z'abrue khashm chin baburd."

ANWAR-r.SUHEILI.

"The seeds of hate are from the breast removed by words that soothe And gentle tongues can all the folds of frowning eye-brows smooth."

EAsTWICK.

" La taj'al yadaka maghlulatan 'ila unuqika wa la tabsuta kulla 'lbasti fataq "uda maluman mahsura."

Kors, chap. x7.

" Let not thy hand be tied up to thy neck; nor yet open it with all openness, lest thou sit thee down in rebuke, in beggary." (RovwelL).

" La t'ajalan biqadhiyyatin mabtutatin

Fi madhi man lam tabluhu au khadshihi ;

Wa qifl "lqadhiyyata flhi hatta tajtali

Wasfaihi fi hala radhahu wa batshihi."

maqamat of Hariri (21). 
" Hasten not with 2 decisive judgment in the praise of him whom thou hast not tried nor in the rebuke of him,

But stay thy judgment on him till thou hast had a view of his two characters in his two conditions of content and anger."

(Chenery).

“Latajlanna 'ashadda 'nnasl 'adawatan llladhina amanu 'lyahuda wa 'lladhina 'ashraku wa latajaddana 'agrabbahum mawaddatan lilladhina amanu 'lladhina qalu "inna Nasara dhalika bi'anna qlssisina wa ruhabanun wa 'annahum la yastakbirun."

KORAN, chap. 5 .

"Of all men thou wilt certainly find the Jews and those who join other gods with God to be the nost intense in hatred of those who believe;/and thou shalt certainly find those to be nearest in affection to them who say 'We are Christians.'// This because some of them are priests and monks, and because they are free from pride."

(RODWELL).

"La takunu ka'llati naqadhat ghazlaha min ba'di quwwatin 'ankathan tattakhidhuna 'aymanakum dakhalan bainakum."

KORAN, chap. 16.

" Be not like her who unravelleth into strands the thread which she had strongly spun by taking your oaths with mutual perfidy." (RoDwelL).

"La tamshi fi 'l'ardhi marahan 'innaka lan takhriqa 'l'ardha wa lan tablugha '1jibala tula."

KORAN, chap. 17.

"Walk not proudly on the earth ; truly thou canst by no means cleave the earth, neither canst thou reach to the mountains in height."

(RODWELL).

"La tamuddanna 'ainaika "lla ma matta'na bihl azwajan minhum wa la tahzan alaihim wa'khfldh Janahaka lilmuminin."

KURAN, chap. 15.

"Strain not thine eyes after the gond things we have bestowed on some of the unbelievers; and afflict not thyself on their account; and lower thy wing to the faithful."

(RODWELL).

"La taqfu ma laisa laka bihi ilmun 'Inna 'ssam'a wa'l basara wa 'Ifuw'ada kullu 'aula'lka kana anhu masula."

KORAN, chap. 17 .

"Follow not that of which thou hast no knowledge; verily the hearing and the sight and the heart ; each for this shall be enquired of."

(RODWRLL).

"La taqulu liman yaqtalu fi sabili 'llahi 'amwatun, bal 'ahyaun wa lakin la tashurun."

KORAN, chap. 2.

"Say not of those who are slain on God's path that they are dead ; nay rather that they are living I but ye understand not." (RoDwELL). 
"Latasbuwanna ila watan flihi tudhamu wa tumtahan W'arhal 'ani 'ddari tu 'll 'lwihada 'ala 'lfutan W'ahrab 'ila kinnin yaqi wa lau 'annahu hidhna hadhan W'alam ba'anna 'lhurra ff 'autanihi yalqa 'lghaban Ka'ddurri fl 'l'asdafl yustazra wa yubkhasu fl 'ththaman." MaQAmat OF HARIRI (chap. 39).

s" To a native place cling not, where folks oppress and hold thee in scant esteem,

But depart the land that exalts the low above the high in dignity,

And take thy flight to a safe retreat, although it were on the skirts of Mount Kaf,

For know full well that a free-born man in his country meets but with disregard

As the pearl within its shell is slighted, and underrated its preciousness." Steingass.

"La t'atibi 'ddhara fl khatbin ramaka bihi

In istaradda faqidman tala ma wahaba."

ZOHAIR.

"Blame not thy fortune when it seems unkind

It does but take back what it gave before." (PALMER).

" Latulhaqna ila 'ssa'ta akhtuha

Sharr'u'ssa'tl 'an tusa ma'awida."

At. Buhturi.

" Add not to ill-doing its sister ; the worst ill-doing is to do ill twice."

D. S. Makgoliouth.

" La turajji 'lwadda mimman yara annaka muhlajun 'ila falsihl."

Maqamat of Hariri, chap. 4.

"Hope not for affection from any who sees that thou art in want of his money."

(Chenery).

" La tay'asan 'inda 'nnuab min farjatin tajlu 'lkurab

Falakum samumin habba thumma jara nasiman fu'nqalab,

Wa sahabi makruhin tanasha fa'dhmahalla wa ma sakab,

Wa dukhani khatbin khifa minhu, fama 'stabana lahu lahab,

F'asbir idha ma naba ra'un, fa'zzaman 'abu 'lajab,

Watarajja min rauhi 'llahi lata'ifan la tuhtasab."

Hariri, Maqamat, 19.

"Despair not in calamities of a gladdening that shall wipe away thy sorrows,

For how many a simoom blows, then turns to a gentle breeze and is changed!

How many a hateful cloud arises, then passes away and pours not forth, And the smoke of the wood, fear is conceived of it, yet no blaze appears from it ;

So be patient when fear assails, for time is the father of wonders, And hope from the peace of God blessings not to be reckoned."

(Chenery). : 
"La taziru waziratun wizra 'ukhra wa'in tad'u muthqalatun ila himliha, la yuhmal minhu shal'un wa lau kana dha qurba."

KORAN, chap. 35 .

" And the burdened soul shall not bear the burden of another, and if the heavy-laden soul cry out for its burden to be carried, yet shall not aught of it be carried, even by the near of kin." (RoDwelL.).

"La tazur man tuhibbu fl kulli shahrin ghair yaumin wa la tazidahu 'alaihi

F'ajtila 'u'lhilall fi 'shshahri yaumun thumma la tanzuru 'laujunu "alaihi." Maqamat of Harire (25).

"Visit him whom thou lovest in each month only a day and exceed not that upon him,

For the beholding of the new moon is but one day in the month and afterward eyes look not on it." CHENery.

"La tubtilu sadaqatikum bi'Imanni wa 'l'adha ka'lladhi yunflqu ma lahu ri'ya 'nnasi wa la yumin bi 'liahi wa 'ljaumi 'lakhiri fa mathaluhu kamathali safwanin aiaihi turabun fa'asabahu wabilun fatarakahu saldan."

KORAN, chap. 2.

" Make not your alms void by reproaches and injury, like him who spendeth his substance to be seen of men, and believeth not in God, and in the latter day. The likeness of such an one is that of a rock with a thin scil upon it on which a heavy rain falleth but leaveth it hard."

(RODWELL).

"La tudrikuhu 'labsaru wa huwa yudriku 'labsara wa huwa 'llatifu 'lkhabir."

KORAN, chap. 6.

"No vision taketh in $\mathrm{Him}$, but $\mathrm{He}$ taketh in all vision and $\mathrm{He}$ is the Subtle, the All-informed."

(RODWELL).

"La tughilanna idha ma sabahta fa"inna 'ssaiamata fl 'ssahill."

Maqamat of Hariri (16)

"Go not in far when thou swimmest for safety is on the bank."

ChENery.

" La tulqu bi eydiyukum ila 'ttahalakati."

KORAN.

"Throw not yourselves with your own hands into perdition."

EAstwick.

"I au 'anfaqta ma fl 'l'ardhi jami'an ma 'alafta baina qulubihim wa lakinna 'llaha 'allafa bainahum innahu azizun hakim."

KORAN, chap. 7 .

" Hadst thou spent all the riches of the earth, thou wouldest not have united their hearts; but God hath united them: He verily is Mighty, Wise."

(RODWELI). 
"Lau 'ansafa 'ddahru fl hukmihi

Lama mallaka 'lhukma 'ahla 'nnaqisa."

Maqamat of Hariri, chap. I.

"If Fortune were just in its decree, it would not empower the worthless with authority."

(Chenery).

"Lau 'an Laila 'alakhailiyyata sallamat 'alayya wa duni turbatun wa safaihu,

Lasallamtu taslima 'lbashashati au zaqa ilaiha sadan min janibl 'lqabri saibu."

Tauba ibn Al Humaivir.

"Ah ! if but Laila once would send me a greeting down

Of grace, though between us lay the dust and the flags of stone, My greeting of joy should spring in answer, or there should cry Toward her an owl, *ill bird that shrieks in the gloom of graves."

C. J. Lyal..

“Lau 'anna lilladhina dhalamu ma fl 'l'ardhi jami'an wa mithlahu ma'ahu, la 'ftadu bihi min su' 'l'azabl yauma 'lqiyamati wa bada lahum mina 'llahi ma lam yakunu yahtasibun."

KORAN, chap. 39 .

"If the wicked possessed all that is in the earth and as much again therewith, assuredly they would ransom themselves with it from the pain of the punishment on the day of resurrection; and there shall appear to them from God things they had never reckoned on." (RoDwELI).

"Lau 'anna ma fl 'lardhi min shajaratin 'aqlamun wa'lbahru yamudduhu min ba'dihi sab'atu 'abhurin, ma naflat kalimatu 'llahi, inna 'llaha azizun hakim."

KORAN, chap. 3 I.

"If all the trees that are upon the earth were to become pens, and if God should after that swell the sea into seven seas (of ink), His words would not be exhausted; of a truth, (jod is Mighty, Wise."

"Lau an suduru 'l'amri yabduna lilfata

K'aqabahu lam talafahu yatanaddamu."

(RODIVELL).

AL IKD AL FARID.

"Were the beginnings of things but as clear to a nuan as are the endings, he would never be found repenting." D. S. MargoliouTh.

"Lau anzalna hadha 'Iqurana ala jabalin lara'altahu khashian mutasaddi'an min khashiati 'llahl wa tilka l'amsalu nadhribuha linnasi laallahum yatafakkurun."

KORAN, chap. 59 .

"Had we sent down this Koran on some mountain, thou would'st certainly have seen it humbling itself and cleaving asunder for the fear of God. Such are the parables we propose to men in order that they may reflect."

(RODWELL).

* The ancient Arabs believed that the ghosts of dead men became owls. 
"Lau kuntu 'alamu 'Ighaiba l'astakathartu mina 'lkhairln wa ma massani "Isu."

KORAN.

"Had I known the future, I should have got myself great good fortune, and no harm should have touched me."

D. S. Margollouth.

"Lau la yakuna 'nnasu 'ummatan wahidatan laja'alna liman yakfuru blrrahmani libuyutihim suqufan min fldhdhatin wa ma 'arlja yadharun, wa libuyutihim 'abwaban wa sururan alaiha yattakiun."

KORAN, chap. 43.

"If it were not that mankind would have become one sect of infidels, verily we had given to those who believe not in the Merciful, roofs of silver to their houses and stairs of silver by which they might ascend thereto, and doors of silver to their houses, and couches of silver for them to lean on."

(SALE).

("La 'uqsimu blyaumi 'lqiyamati, wa la uqsimu bi'nnafsi 'llawwamatf, 'ayahsabu 'linsanu 'an lan najma'a idhamahu bala qadirina ala "an nusawwia bariahu."

KORAN, chap. 75.

C"I swear by the Resurrection, and I swear by the self-accusing soul. Thinketh man that we cannot re-unite his bones? Aye, his very finger bones are we able evenly to replace."

(RONWELL).

"Lau yuakhidhu 'llahu 'nnasa bima kasabu ma taraka 'ala dhahriha min dabbatin walakin yu akhlruhum ila 'ajalin musamma."

KORAN, chap. 35 .

"If moreover God should chastise men according to their deserts, $\mathrm{He}$ would not leave even a reptile on the back of the earth. But to an appointed time doth He respite them."

RODWELL.

"La yablughu ahadun darjata 'lhaqiqati hatta yashada flhi alfu sidiqin bi annahu zindiqun." JUNAID.

"No one attaineth to the degree of truth until a thousand righteous men bear witness that he is an atheist."

"La yadkhuluna 'ljannata hatta yallja 'ljamalu fl samml 'lkhayyati."

KORAN, chap. 7.

"Nor shall they enter Paradise until the camel passeth through the eye of the needle."

(RODWELL).

"La yaltamu ma jaraha 'llisanu."

Prov.

"Wounds of the tongue are never healed."

"La yamassuhu illa 'mutahharun."

Korax, chap. $56.1 .7^{8}$

"Let none touch it " but the purified."

"The Koran. 
"La yaraddu 'ljaza' fatila wa la yuhiu 'lasafu man ghada bissaifl' "lmuniyati qatila."

ABU't. Ala.

" Despair will bring nothing back neither will grief hring him to life whom the sword of fate has once slain." D. S. Margoliouth.

"La yas'amu 'linsanu min du'ai 'lkhairl wa'in massahu' sharru faya'usun qanut."

KORAN, chap. 4x.

" Man is never weary of praying for good, but if evil betide him, he is then desponding, despairing."

(RODWELL).

"La yastawi 'lkhabithu wa "ttayibu wa lau a'jabaka kathratu 'lkhabithi , fa'ttaqu 'llaha ya 'uli'lalbab la'allakum tuflihun."

Koran, chap. 5 .

"The evil and the good are not to be valued alike even though the abundance of evil please thee ; therefore fear God, $O$ ye of understanding ! Haply it shall be well with you."

(ROINVELL).

"La ya'zubu 'anhu mithqalu dharratin fi 'ssamawati wa la fi 'lardhi wa la 'asgharu min dhalika wa la akbaru illa fl kitabin mubin."

Koran, chap. 34 .

"Not the weight of a mote either in the heavens or in the earth escapeth $\mathrm{Him}$; nor is there aught less than this, or aught greater which is not in the perspicuous Book."

RODWELL.

"La yughlaqu babu 'ttaubati 'ala 'l'ibadi hatta tatla'u 'shshamsu min maghribihi."

Gulistan, chap. 5 .

"The door of repentance shall not be closed against the servants of God till the sun rise from the West."

(Platts).

" La yuldaghu 'Imuminu min hujrin wahidin maratain."

Arabic Proverb.

"The believer will not be stung from one hole twice."

EASTWICK.

"La yusibuhum dhamaun wa la nasabun wa la makhmasatun fi sabili 'llahi wa la yata'una mutian yaghidhu 'lkuffara wa la yanaluna min aduwwin nllan illa kutiba lahum bihi amalun salihun inna 'llaha la yudhi'u 'ajra 'lmuhsinin."

KORAN, chap. 9 .

"Neither thirst nor labour nor hunger can come upon them when on the path of God, neither do they step a step which may anger the unbelievers, neither do they receive from the enemy an injury but it is written dcwn to them as a good work; verily God will not suffer the reward of the righteous to perish."

(RODWELL).

"Libas ki hargiz na farsud sabr ast."

AKHL.AQ-J-MUHSINI.

"The dress that never wore out is patience." KEENE. 
" Likulli 'nnasin makbarun bifana'ihim fahum yanqusuna wa 'Iquburu tazidu,

Wa ma 'in yazalu rasmu darin ukhlaqat wa baitun limaitan bi 'lfana'l jadidu,

Hum jiratu 'lahya "amma jiwarubum fadanin wa'amma 'imultaqa faba'idu."

Aboallah jhe Tha'tabalt.

"Before the door of each and all a slumber-place is ready set :

Men wane and dwindle and the graves in number grow from day to day;

And ever more and more outworn the traces fade of hearth and home,

And ever yonder for some dead is newly built a house of clay,

Yea neighbours are they of the living; near and close their fellowship

But if thy soul would seek their converse, thou must seek it far away."

C. J. Lyall.

"Lillahi kunuzun tahta 'l'arsbl mafatihuha alsinatu 'shshu'ara."

Sayixg of MUhammad.

"God hath treasuries beneath the throne, the keys whereof are the tongues of the poets."

"Lillahi yasjudu ma fl 'ssamawati wa ma fi 'l'ardhl min daabbatin wa 'Imalaikatu wa hum la yastakbirun yakbafuna rabbabum min fauqlhim wa yaf'aluna ma yumirun."

KORAN, chap. 16.

"All in the heavens and all on the earth, each thing that moveth and the very angels prostrate themselves in adoration before God and are free from pride; they fear their Lord who is above them, and do what they are bidden."

(RODWELL).

" Ii ma'a 'llahi waqtun la yas'auni fihi malakun muqarrabun wa la nabiyyun mursalun." Saying of Muhammad.

"I have a season with God in which neither ministering angel nor any prophet that has been sent, can vie with me." .

(EASTWICK).

“ Lisanu 'Ifata nisfun wa nisfun fuwaduhu

Falam yabka illa suratu 'llahmi wa 'ddami

Wa ka'in tara min samitin laka mu'jibin

Ziyadatuhu au naqsuhu fi 'ttakallami."

Muallakall of Zuhair.

" The tongue is a man's one half, the other the heart within,

Besides these two nought is left but a semblance of flesh and blood, How many a man seemed goodly to thee while he held his peace,

Whereof thou didst learn the more or less when he turned to speech.

C. J. LyalL.

" Litafat kun an ja ki bini sitiz

Na barrad qaz-i-narmra tigh-i-tiz

Bashirin zabani wa lutf wa khushi

Tawani ki pile ba mui kashi."

Gulistan, chap. 3. 
"When thou seest broils arise, use courtesy, A sharp sword cuts not silk, though soft it be. With honeyed words, good humour on thy side, Thou with a hair an elephant may'st guide." (EASTwICK).

"Luqman-i-hakimra guftand 'hikmat az kih amukhti?' Guft 'az nabinayan ki ta jae na binand pae na nihand." Gulistan, Preface.

"They said to the sage Luqman, 'From whom didst thou learn wisdom?' He replied, 'From the blind who advance not their feet, till they have tried the ground."

(EASTWICK).

"Lutfe na mand, k'an sanam-i-khushlaqa na kard, Mara che jurm gar karamash ba shuma na kard? Tashni' mi zani ki jafa kard an nigar, Khube kih did dar du jahan, ki jafa na kard? Chun ruh dar nazara fana gasht, in biguft, 'Nazara-i-jamai-i-khuda juz khuda na kard' In chashm wa an chiragh du nurand har yake, Chun in baham rasid, kase shan juda na kard."

Diwan-I-Shams-I-Tabriz.

"No favour was left which that winsome beauty did not bestow,

What fault of ours if he failed in bounty towards you?

Thou art reviling because that charmer wrought tyranny,

Whoever saw in the two worlds a fair one that played not the tyrant?

When the spirit became lost in contemplation, it said this

'None but God has contemplated the beauty of God ;'

This eye and that lamp are two lights, each individual,

When they came together, no-one distinguished them."

(Nicholson).

"Ma 'arafnaka haqqa m'arifatika."

Gulistan (Preface).

"We have not known Thee as Thou oughtest to be known."

"Ma'ash chunan kun, ki gar bilaghzad pai

Firishta'at badu dast-i-du'a nigah darad."

(EASTWICK).

HAFIZ ODE, ${ }_{446 .}$

"So live, that if thy foot slip e'er, Angels may guard thee by the hands of prayer."

“ Ma 'ashiq wa ashufta wa mastim imruz

BickNell.

Dar ku-i-maghan bada parastim imruz

Az hasti-i-khwishtan bikulli rasta

Paiwasta bimihrab-i-'alastim imruz."

Omar Кнayyas

"To-day to love and rapture we have soared,

To-day in Magian precincts wine adored, And rapt beyond ourselves we do abide, Within that tavern, 'Am I not your Lord?'"

WHINFIELD. 
"Ma 'atazaltu hatta jadadtu wa hazaltu, fa wajadtanl la aslaha ijadi wa la bazli, fa "indaha radhitu bil' uzll."

ABU'L ALA.

"I did not retire from the world till I had both worked and played, and finding myself unfit for either, I had to be satisfied with ennui."

" Ma ayyal hazratim wa shira khwah

D. S. Margoliouti.

Guft 'alkhalqu ayyalan l'lllah:'

An ki u az asman baran dihad

Ham tawanad k'u za rahmat nan dihad."

Jalaluddin Rum.

"We are the family of the Lord and His sucking babes, The Prophet said 'The people are God's family,'

He who sends forth the rain from heaven,

Can He not also provide our dzily bread?"

(WIINFIELD).

" Mabada dil an mardam ahanin shad

K1 az bahr-1-dunya dihad din babad."

Pandana of S'aut.

"Let not the heart of that man of iron rejoice

Who for this world giveth futurity to the wind."

"Mabada kas kd az zan mihr Juyad

Kl az shura bayaban gul na ruyad."

Gladwin.

"Forbid it one in woman's nature should for gentle feelings look,

Ne'er amid the brackish desert roses home ungenial took."

" Ma ba falak buda im, yar-1-malak buda im

EASTwick.

Baz hamanja rawim, khwaja, ki an shahr-1-ma'st

Alam-i-khak az kuja, gauhar-1-pak az kuja

Garchi farud amadim baz dawim, in chl ja'st?"

Diwan.1-Shams-1-TABRiz.

"We have been in heaven, we have been friends of the angels

Thither, sire, let us return for that is our country,

How different a source have the world of dust and the pure substance, Though we came down, let us haste back-what place is this?"

"Mabar nam-1-wafa dar bazam-i-khuban

Ki bue az wafadari na dari."

(NichOLSON).

ANWAR·I.SUhBILI.

" $O$ speak not thou of faithfulness where feast the frank and free, For not an atom of good faith its fragrance sheds on thee."

"Ma blrun-ra nangarim wa qalra

Eastwick.

Ma darun ra bingarim wa halra;

Nazir qalbim agar khash 1 buad

Garchl guft lufz na khaz'l buad;

Z'anki dil jauhar bud, guftan 'arz,

Pus tufail amad 'arz, jauhar gharz;

Chand az in alfaz wa izmar wa majaz

Suz khwaham, saz ba an suz baz."

JALALUDDIN RUMI. 
"I regard not the outside and the words, I regard the inside and the state of heart; I look at the heart if it be humble, Though the words may be the reverse of humble; Because the heart is substance and words accidents, Accidents are only a means, substance is the final cause. How long wilt thou dwell on words and superficialities, A burning heart is what I want ; consort with burning."

" Ma dar khwar dilera agarchi khwar buwad

(WHINFIELD).

Ki bas aziz dilast wa aziz dar an dari, Dile kharab chu manzargah jlahi buwad Zahi, s'aadat-i-jani ki kard m'amari."

DIWAN-I-SHAMS-I-TABRIZ.

" Then think not lowly of thy heart, though lowly, For holy is it and there dwells the loly, God's presence-chamber is the human breast, Ah ! happy spirit with such Inmate blest." (FALCONER).

" Ma dha akhadhaka ya maghruru fl 'lkhatari Hatta halakta falaita 'nnamlu lam tatir."

Gulist AN, chap. 3.

"What was it that plunged thee, deluded one into danger,

So that thou perished? Would that the ant had not got wings and attempted to fly?"

(PlatTS).

"Mague anchi taqat na dari shanud Ki jau kishta gandam na khwahi dirud."

Bostan of S'ADI.

"Utter not what thou hast not the power to hear, For, having sown barley, thou wilt not reap wheat."

" Magu 'shayad in mar kushtan bichub'

(Clarke).

Chu sar zir-i-sang-i-tu darad, bikub;

Bad andishra jae wa fursat madih

Adu dar chah wa div dar shisha bih."

Bostan of S'AdI, chap. 2.

" Say not 'it is proper to kill this snake with a stick,'

Strike, when he has his head beneath thy stone,

Give neither place nor opportunity to the malignant one ;

The enemy in the pit and the demon in the glass bottle is best."

(CLARKE).

"Magzar ki zih kunad kaman ra

Dushman,-chu ba tir mitawan dukht."

Gulistan, chap. 8.

"Ere yet his bow

Be strung, thy arrow should transfix the foe."

(EAsTwick).

"Mahakk danad ki zar chist."

Gulistan, chap. 7 .

"The touchstone discerns the gold." 
" Ma hama ajza Adam buda Im

Dar bihisht an lahana bishnuda im;

Garchi bar ma rikht ab wa gil shake,

Yad man ayad azlanha andake,

Lek chun amikht ba khak karb,

Kal dihad in zir wa in ham an tarab."

JALALUDDIN RUM.

"As we are all members of Adanı

We have heard these melodies in Paradise;

Though earth and water have cast their veil upon us

We retain faint reminiscences of those earthly songs;

But while we are thus shrouded by gross earthly veils

Huw can the tones of the dancing spheres reach us?"

" Mah flshanad nur wa sag 'au! au!' kunad

Har kase bar khalqat-i-khud mi tanad

Har kase ra khidmate dada qaza."

WHINYIELD.

"The moon slieds her light and the dogs howl;

Everyone acts according to his nature,

To each his office is allotted by the divine decree."

"Mahram hasti, ki ba tu guyam yak dam,

WHINFIELD.

K'az awwal kar khud chi bud ast Adam

Mihnat-zada'e sarishta andar gil-i-gham

Yak chand jahan bikhurad wa bardasht qadam." OMAR KHAvvas.

"To confidants like you I dare to say

What mankind really are :-moulded of clay;

Aflliction's clay, and kneaded in distress,

They taste the world awhile, then pass away."

"Mail-i-tan dar sabza wa ab rawan

(WIINEIELD).

Z'an bud ki asl-i-u amad azan ;

Mail-i-jan dar hikmat wa dar ulum,

Mail-i-tan dar bagh wa ragh wa dar karum;

Mail-i-jan andar taraqqi wa sharf,

Mail-i-tan dar,kasb_asbab wa 'aiaf."

JALALUdDIN RUML.

"The body loves green pastures and running water,

For this cause that its origin is from them.

The love of the soul is for wisdom and knowledge,

That of the body for houses, gardens, and vineyards ;

The love of the soul is for things exalted on high,

That of the body for acquisition of goods and food."

(WHINFIELD).

"Ma "indakum yanfadu wa ma 'inda 'llahi bagin walanajziyanna 'lladhina sabaru 'ajrahum bi'ahsani ma kanu ya'malun."

KORAN, chap. 16. 
"All that is, with you passeth away, but that which is God abideth. With a reward meet for their best deeds will we surely recompense those who have patiently endured."

(RODWELL).

“ $\mathrm{Ma}$ 'in yadhuru 'ladhba kaunu qarabihi khalaqan wa la 'lbazi haqaratu 'ashshihi.

MaqaMat of Hariri, 2 t.

"It hurts not the sword that its sheath be worn, nor the hawk that its nest be mean."

Chenery.

"Ma ja'ala 'llahu lirajulin min qalbaini fl jauflhi." Koras, chap. 33.

" God hath not given a man two hearts within him." Ronwell.

"Majmu'a-i-kawn-ra bi kanun-i-sabak

Kardim tasaffuh varakan ba'da varak :

Hakka ki na-khwandim $u$ na didim dar $u$

Juz zat-i-Hakk u sifat-i-zatiyye-i-Hakk."

"Like a lesson-book the compendium of the universe

We turned over, leaf after leaf ;

In truth we read and saw therein naught

Save the Essence of God and the Essential Attributes of God."

"Maju sa'adat wa daulat dar in jahan ki nayabi,

(E. G. BROWNE).

Za bandagiash talab kun sa'adat du jahani."

Diwan-I-Shams-I-TABRIz.

"Look not in the world for bliss and fortune, since thou wilt not find them,

Seek bliss in both worlds by serving Him."

(NICHOLSON).

"Ma kana libasharin 'an yukallimahu 'llahu illa wahian au min wara' hijab."

KorAN, chap. 42 .

"It is not for man that God should speak with him, but by revelation or from behind a veil."

(RODWELL).

"Ma kana rabbuka muhlika 'lqura hatta yab'atha fi 'ummiha rasulan yatlu alaihim ayatina wa ma kunna muhliki "lqura illa wa ahluha dhalimun."

KORAN, chap. 28.

"Thy Lord did not destroy those cities till He had sent an apostle to their mother city to rehearse our signs to its people; nor did we destroy the cities unless their people were unjust."

(RODWELL).

"Makar-i-Shaitanast t'ajil wa shitab

Lutf-i-Rahman ast sabr wa ijtinab;

B'atanni gasht maujud az khuda

Ta ba shash ruz in zamin wa charkhha

Warna qadir bud k'u az 'kaf' wa 'nun'

Sad zamin dar yak dam awardi birun

In tanni az pa'e t'alim-i-tu'st

Sabr kun, dar kar-i-u dar ai durust." . 
"Hurry and rashness from the devil spring,

But patience, meekness, are from heaven's king,

See from God's hand creation slow arise

And six days' labour claimed by earth and skies,

Else with two letters He possessed the might

Sudden to make new worlds upstart to light.

Lo ! in this course instruction to us sent;

Use patience, for with it success is blent."

EASTWICK.

"Makaru makrahum wa inda 'llahi makruhum wa'in kana makruhum litazula minhu 'ljibal."

KORAN, chap. 14.

"They plotted their plots; but their craftiness was under the control of God, even though their craftiness had been such that the mountains should be moved by it."

(RO1)IVE1.L).

"Ma khalaqa 'llahu min shaian yatafayyau dhilaluhu 'ani 'lyamini wa' shshama'ili sujjidan lillahi."

KokAn, chap. 16.

" Everything which God hath created turneth its shadow right and left, prostrating itself before God."

(RODWELL).

“ Ma khalaqna 'ssamal wa 'lardha wa ma bainahuma batilan dhalika dhannu 'lladhina kafaru fa wallun lilladhina kafaru mina 'nnari."

KORAN, chap. 37 .

"We have not created the heaven and the earth and what is between them for nought. That is the thought of unbelievers; but woe to those who believe not because of the fire!"

- Rodwell.

“ Ma khalaqna 'ssama'i wa 'l'ardha wa ma bainahuma la ibin lau 'aradna an nattakhidha lahwan la'ttakhadhnahu min ladunna in kunna fa'ilin."

KORAN, chap. 21 .

"We created not the heaven and the earth and what is between them for a sport;

Had it been our wish to find a pastime, we had surely found it in ourselves; if to do so had been our will."

(RODWELI.).

"Ma khalaqtu 'ljinn wa 'lins, in blkhwan,

Juz ibadat nist maqsud az jahan;

Garchi maqsud az kitab an fann buwad

Gar tu ash balish kuni ham mishawad;

Lekin az maqsud in balish na bud

Ilm bud wa danish wa irshad wa sud."

Jalaludin Rum.

" Read the text 'I have not created Jinns and men but to worship me,' The only object of the world is to worship God.

Though the object of a book is to teach an art, If you make a pillow of it, it serves that purpose too,

Yet its main olject is not to serve as a pillow

But to impart knowledge and useful instruction."

(WHINFIRL). 
Makun shadmani bimarg-i-kase Ki dahrat na manad pas az wai base."

Bostan of S'Adi.

"Indulge not joy at the death of another, for fortune will not long spare thyself after it."

(FALCONER).

"Makun za ghussa shikayat ki dar tariq-i-talab

Ba rahate na rasid anki zakhmate na kashid."

ANWAR-I-SUHEILI.

"Give not vent to angry wailings for in seeking ought be sure,

(1. They alone attain to gladness who can sadness first endure."

"Ma l'abatganim wa falak l'abat baz

EASTWICK.

Az ru-e-haqiqati na az ru-e-majaz

Bazicha hamkunim bar nat'a-e-wujud

Raftim ba sanduq-i-'adam yak yak baz."

OMAR KHAYYÄM.

" We are but chessmen destined it is plain, The great chess-player Heaven to entertain; Us men It moves about the board of life, Then in the box of death shuts up again."

(WHINFIELD)

“ Mal k'az wai bukhil bahra na yaft

Dast-i-taraj dad bar bad ash,

Ya:ba waris rasid wa ki gahe

Juz banafrin na mi kunad yadash."

Anwar+1-Suheili.

" The wealth the miser naught enjoyed is cast

$\mathrm{By}$ the rude hand of spoilers to the wind;

Or has to some ungrateful heir now passed

Who but with loathing calls his name to mind."

"Mal ra gar bahri din bashi hamul

N'im mal salih guftash rasul."

EASTWICK.

JALALUdDin Rumi.

"If for the Faith thou bear'st thy wealth, it then

The Prophet says, is pure to righteous men." Eastwick.

“ Ma min da'abbatin fi 'lardhi illa ala 'llahi rizquha wa ya'lamu mustaqarraha wa mustauda 'aha, kullun fl kitabin mubin."

KORAN, chap. II.

"There is no moving thing on earth whose nourishment dependeth not on God, and $\mathrm{He}$ knoweth its haunts and final resting-place; all is in the clear Book."

(RODWELL).

“ Ma"min da'abbatin fl 'l'ardhi wa la ta'irin yatiru bijanahihi 'illa 'umamun 'amthalukum ma farratna fl 'lkitabi min shaian thumma "ila rabbihim yuhsharun."

Koran, chap. 6 .

"No kind of beast is there on earth nor fowl that flieth with its wings but is a folk like you: nothing have we passed over in the book; then unto their Lord shall they be gathered."

(KONWELL). 
"Ma min da'abbatin llia huwa akhidhun binasiyatiha."

KORAN, chap. Ix.

" No moving creature is there which He holdeth not by its forelock."

RoDWFL.L.

"Ma min gharibin wa'in abda tajalluduhu

Illa sayadhkaru inda 'llilate 'Iwatana."

"There is no stranger though he make boast of his fortitude, but remenilers his home at times of sickness." $\quad$ D. S. Margoliouth.

" Ma min mauludin illa wa qad yuladu 'ala fitrati 'lislam faabawahu yuhawwidanihi au yunassiranihi au yumajjisanihi."

Saving of Muhammad.

"There is no person born but assuredly he is begotten to the faith of Islam ; then his parents make a Jew of him, or a Christian or a Magian."

(EASTIVICK).

"Man 'adhallu mimmani 'ttaba'a hawahu bighairi hudan min 'llaht "inna 'llaha la yahdi 'Iqauma dhohalimin."

KORAN, chap. $28 . V .50$

"Who goeth more widely astray than he who followeth his own caprice without guidance from God? (Verily God guideth not the wicked.")

(RODWELL).

"Man 'adhlamu mimman dhukkira biayati rabbihi thumma a'radha "anha, inna mina 'Imujrimina muntaqimun."

KORAN, chap. 32.

"Who acteth worse than he who is warned by the signs of his Lord, then turneth away from them? We will surely take vengeance on the guilty ones."

(RODWELI.).

"Man "allamani harfan faqad sayyarani "abdan."

Proverb.

"Whoso hath taught me a letter hath made me his slave."

“ Manam Isa'e khushkhanda ki 'alam shud baman zinda Wale nisbat za haqq daram man az Miryama na mi-daram."

DIWAN-1-ShaMS-1-TABRIZ.

"I am sweet-smiling Jesus by whom the world is revived, But my lineage is from God : I know nought of Mary."

“Man an muram ki dar payam bimaland,

NichOLSON.

Na zamburam ki az nisham binaland;

Kuja shukr-i-in ni'mat guzaram

Ki zur-1-mardum azari na daram."

Gulistan, chap. 3-

"I am the ant which under foot men tread And not the hornet whose fierce sting they dread; How for this boon shall I my thanks express, That I to injure man am powerless."

Eastivick. 


\section{"Man an ruz budam ki 'asma nabud Nishan az wujud-i-musamma nabud Nishan gasht mazhar sirr-i-zulf-i-yar Bajuz mazhar-i-Haqq Taala nabud Musamma wa 'asma za ma shud padid Dar an dam ki anja man wa ma nabud Man an dam bikardam khudara sujud Ki dar batn-i-Miriam Masiha nabud."}

Diwan-l.Shams-1-Tabriz.

"I was, ere a name had been named upon earth, Ere one trace yet existed of aught that has birth : When the locks of the Loved One streamed forth for a sign, And Being was none save the Presence Divine! Named and name were alike emanations from $\mathrm{Me}$, Ere aught that was 'I' $y$ et existed, or 'We'; Ere the veil of the flesh for Messiah was wrought, To the Godhead I bowed in prostration of thought."

\section{"Man az Quran maghz ra bardakhtan}

Ustukhwanra pish-i-sagan andakhtam."

(FALCONER)

Jalaidudin Rumi.

"I extracted the marrow of the Koran, and threw the bone to the dogs."

"Man chang-i-tu am, bar har rag-i-man

Tu zakhma zani, man tanatanam."

Diwan-1-Shams-1.Tabrtz.

"I am thy lute, on every vein (chord) of mine Thou strikest the quill, and I vibrate." (NICHOLSON).

"Man dha 'lladhi ma sa'a katt,

Waman lahu 'Ihusna fakatt?

Kam fliatin saiyi-atin

Warratana fiha'l ghalat."

HARIRI.

"Who is there that never does evil at all, and who is there who has only good qualities ; into how many an evil deed error has plunged us !"

"Man ghuiam-i-an ki u dar har rabat

(PALMER).

Khwish'a wasil na danad bar samat.

Bas rabate ki babayad tark kard,

Ta ba maskan dar rasid ek ruz mard."

Jalaludin Rumi.

"I'll be the very slave of him who at each stage

Will not suppose the goal 'tis of his pilgrimage;

Before the traveller reach the home he bears in mind

How many stages are there must be left behind !"

" Man hasil-i-umr-i-khud na daram juz gham

(REDHOUSE).

Dar 'ishq za nik wa bad na daram juz gham

Yak hamdam-i-damsaz nadaram nafsi

Yak m'unis-i-namzad nadaram.juz gham."

HAFiz. 
" Nought from my" life passed here save grief have I, Nought from love's hope and fear save grief have I, I have no intiınate, no hosom friend, No one who holds me dear, save grief, have I."

BHCKNELI.

" Ma nih dil bar in kakh-1-khurram hawa Ki mibarad asmanash bala."

PandNama or S'All.

"Fix not the heart upon this inansion of pleasant breezes, For its sky rains down calanity."

Gladwin.

"Ma nih gush ba qaul ahl-i-gharz

$\mathrm{K}^{\prime} \mathrm{az}$ ishan rasad mal wa din ra shikast

Gharzju agar az tu shud sar-buland

Shawad pae qadr wa jah-i-tu past

Agar ba hasudan shudi hamrikab

'Inan-i-buzurgi bidadi za dast."

ANWAR-I-SUHEIL.T.

" Iet not the ear to selfish men be lent, For they will injure both the faith and state As sycophants through thee grow eminent, So will thy greatness and thy power abate; If to the envious thou dost yield consent, Of thy free-will thou ceasest to be great." EAstwick.

"Mani 'htada fa "innama yahtadi linafsihi wa man dhalla fa "innama yadhillu alaiha wa la taziru waziratun wizra 'ukhra wa ma kunna muadhibina hatta nab'atha rasula."

KORAN, chap. 17.

"For his own good only shall the guided yield to guidance, and to his own luss only shall the erring err, and the heavy laden shall not be laden with another's load. And we punished not till we had first sent an apostle."

(RODWELL).

" Manishin tursh az gardash-i-ayyam ki sabr

Talkhast wa lekin bar-i-shirin darad."

Gulistan, chap. :

"Sit not sad because that time a fitful aspect weareth,

Patience is most bitter, yet most sweet the fruit it beareth."

(EASTwick).

"Man jarraba 'lmujarrab hallat bihi 'nnadamat."

DIWAN*I-Shans-I.TABRIZ.

"Repentance lights on him who tests one tested already."

(NICHOLSON)

"Man kafara fa'alaihi kufruhu wa man amila salihan fa li 'anfusihim yamhadun."

KORAN, chap. 30 .

"He who disbelieves, on him shall be his unbelief, and they who have wrought righteousness, verily they shall spread for themselves couches of repose."

(RODWELL). 
"Man kana baina yadaihi ma ashtaha ratabun Yugnthi dhallka "an rajmi 'l'anaqid."

Gui.rstan, chap. 7 .

"Who holds the dates he loves his hands between Contented pelts the clusters not Ijween."

EAstwick.

“ Man kana yarju liqai 'llahi fa'inna 'ajala 'llahi'la atin wa huwa 'ssami'u 'l'alim, wa man jahada fa innama yujahidu linafsihi, inna 'laha laghaniun "ani 'l'alamin."

KORAN, chap. 29.

"To him who hopeth to meet God, the set time of God will surely come. The Hearer the Knower, He! and whoso maketh efforts maketh them for his own good only. Verily God is rich enough to dispense with all creatures."

(RODWELL).

“Man kana yuridu 'lizzata, falillahi 'l'izzatu jami'an, ilaihi yas'adu 'lkalimu 'ttaiyyibu, wa'l'amalu 'ssalihu yarfa'uhu."

Koka.N, chap. 35 .

"If any desireth greatness, greatness is wholly with God. The good word riseth up to Him, and the righteous deed doth He exalt."

(RODWELl.).

" Man ki sulham daima ba in pidar,

In jahan chun jannatastam dar nazar ;

Har zaman nau surate wa nau jamal,

Ta za nau didan faru mirad malal;

Man hame binam jahan ra az naim

Abha za chashma jushan muqim."

JALALUDDIN RUMr.

"I am ever in concord with this father of ours, And earth ever appears to me as a Paradise ;

Each moment a fresh form, a new beauty,

So that weariness vanishes at these ever-fresh sights ;

I see the world filled with blessings,

Fresh waters ever welling up from new fountains."

WHINFIELD.

"Man qala 'ana' waq'a fl 'l'ana."

Arajic Proverb.

"Whoever says 'I' falls into trouble."

"Man talaba, wajada."

Arabic Proverb.

"Who seeks, finds."

"Man sannafa faqad istahadafa."

Proverb.

"He who composes, makes himself a butt."

“ Man wa tu bi man wa tu jam'a shawim az sar-i-zauq

Khush wa farigh za khurafat-i-parishan man wa tu

Tutian-i-falaki jumla jigar khwar shawand

Dar maqame ki bikhandim bar an shan man wa tu."

Diwan-1-Shams-t.Tabriz. 
" Thou and I individuals no more shall be mingled in ecstasy, Joyful and secure from foolish babble, thou and I.

All the bright plumed lirds of heaven will devour their hearts with envy In the place where we shall laugh in such a fashion thou and I."

(Nicilolson).

"Man yahdi 'llahu fa huwa 'Imuhtadi wa man yudhlil fa 'aula'ka humu lkhasirun."

KORAN, chap. 7.

"He whom God guideth is the guided, and they whom IIe misleadeth are the lost."

ROINEL.I.

"Man yushrik b'illahi faka 'annama kharra min 'ssama'i fatakhatufu 'ttairu au tahwi bihl 'rrihu fl makanin sahiq."

KoKAN, chap. 22.

"Whoever uniteth gods with God is like that which falleth from on high, and the hirds snatch it away, or the wind bloweth it away to a distant place."

(RODWELL).

"Man yuslim wajhahu il 'llahi wa huwa muhsinun faqadi 'sstamsaka bi 'lurwati 'luthqa wa il 'llahi 'aqibatu 'lamur."

KOKAN, chap. 3 I.

"Whoso setteth his face toward God with self-surrender and is a doer of that which is good, hath indeed laid hold of the surest handle : Verily unto God is the issue of all things."

RODWELL.

"Man yuta hikmata faqad uta khairan kathira." KокA., chap. 2.

" He who has received wisdom, has received a great gnod."

(EASTWICK).

" Man yuti'i 'llaha wa rasulahu, faqad faza fauzan adhima."

KORAN, chap. 33 .

"Whoso obeyeth God and Itis apostle, with great bliss surely shall he be blessed."

RODWELL.

"Maparwar tan ar mard-1-rae wahshi

Ki ura chu mi-parwari mi-kushi."

BOSTAN OF S'ADI, chap. 6.

"If thou art a man of judgment and sense, cherish not thy body, For, when thou cherishest it, thou slayest it." (CLARKE).

"Mapindar agar shir wa gar ruba'i

K'az inan bimardi wa hilat rihi."

Bostan of S'ADI, chap. 7.

" Whether thou art a lion or a fox, think not

That thou mayest escape from these slanderers by manliness or stratagem."

(CI.ARKE).

"Ma qadaru 'llaha haqqa qadrihi, inna 'llaha laqawiyyun, 'aziz." 
"Unworthy the estimate they form of God! Verily God is powerful, mighty."

(Ronwei.1.).

"Maqam-i-aman wa mai bigash wa rafiq-i-shaflq

Garat mudam muyassar shawad zihi tauflq

Jahan wa kar-i-jahan jumla hich dar hich ast

Hazar bar man in nuqta karda am tahqiq."

HAFIZ ODE, 350.

"A peaceful spot, unmingled wine, and a congenial mate,

If these should be thy lot below, be thankful for thy fate,

The world and what the world performs are but as nought in nought,

This verity a thousand times has to myself been taught."

(BICKNeli.).

' Maqsud az jumla afrinash mayim

Dar chashm-i-khirad jauhar biniash mayim

In daira'e jahan chu angushtare ast

Bi hich shakki naqsh-i-naginash mayim."

Omar Khayyam.

"Man is the whole creation's summary,

The apple, as it were, of wisdom's eye ;

The circle of existence is a ring

Whereof the signet is humanity."

(WhINFIELD).

"Ma ramaita 'idh ramaita wa lakinna 'llaha rama." KoRAN, chap. 7 .

" Thou did'st not cast when thou did'st cast, but God cast."

(RODWEIL).

"Mara bamarg-i-'adu jae shadmani nist

Ki zindagani ma niz jawidani nist."

Gulistan, chap. I.

"In my foe's death what joy is there for me?

For my life, too, cannot eternal be." (Eastwick).

"Marg-i-tan hadiya ast ba sahib raz

Zar khalis ra chi nuqsanast kaz."

JaLALudin Rum.

"Death of the body is a benefaction to the spiritual,

What damage has pure gold to dread from the shears."

" Marg agar mard ast, gu 'nizd-i-man a

(WhINFIEI,D).

Ta dar aghushash bigiram tang tang

Man az u umri sitanam jawidan

U za man dalqe sitanad rang rang.' "

JALALUDDIN RUMI.

"If death be a human being say to him 'Draw near

That I may closely fold him in a fond embrace,

From him I extort by force eternal life,

Whilst he but snatches from me the dervish's party-coloured dress.' "

(SHeA). 
" Mastan-1-khuda garchi hazarand, yake and, Mastan-1-hawa, garchl yakanast, duganast."

DIWAN-I.SHAMS-I.TAHRI7.

"Those drunk with God though they be thousands, yet are one,

Those drunk with lust, though it be a single one, he is a double."

(Nicholsox).

"Ma tadri nafsun ma dha taksibu ghadan wa ma tadri nafsun bl'ayya ardhin tamutu, inna 'llaha "alimun khabir."

KокAN, chap. 3r. V. 34

"No soul knoweth what it shall have gotten on the norrow; neither knoweth any soul in what land it shall die. Verily God is knowing, informed of all."

(ROINELI.).

“Mathalu 'lladhina hummilu 'ttaurata thumma lam yahmiluha kamathali 'lhimari yahmilu 'asfaran." KoRAN, chap. 62.

"The likeness for those on whon the burden of the law was laid, and who afterwards would not bear it, is that of an ass beneath a load of books."

(RODWELL).

" Mathalu 'lladhina yunflquna 'amwalahum fl sabill 'llahi kamathali habbatin 'anbat sab'a sanabila fl kulli sunbulatin mi'atu habbatin wa 'llahu yudhaifu liman yashau wa 'llahu wasiun 'alim."

Kokan, chap. 2.

"The similitude of those who spend their substance in the service of God is as the similitude of a grain of corn which produceth seven ears, in every ear a hundred grains; for God giveth the increase to whom He pleaseth : God is bountiful and wise."

(MUIR).

"Mathalu 'lladhina 'ttakhadhu min duni 'llahi auliya'kamathali 'lankabutl ttakhadhat baltan wa'inna 'auhana 'lbuyuti 'lbaitu 'lankabuti lau kanu ya'lamun."

KORAN, chap. 29. V. 40

"The likeness for those who take to themselves guardians besides God is the likeness of the spider who buildeth her an house; but verily frailest of all houses is the house of the spider. Did they but know this !"

(Rovivel.1.).

"Mathaluhum kamathali 'lladhi 'stauqada naran, falamma 'adha'at ma haulahu, dhahaba 'llahu binurihim wa tarakahum $\mathrm{f}$ dhulumatin la yubsirun, summun, bukmun, umun, fahum la yarj1'un."

Koras, chap. 2.

"They (the infidels) are like one who kindleth a fire, and when it hath thrown its light on all around him, God taketh away their light, and leaveth them in darkness they cannot see. Deaf, dumb, blind; therefore they retrace not their steps from error." (Ronwel.L). 
" Matlub chun ba dast buwad maghnatam shumar Wa an ra za kaf madih ki pashimani award Bisyar kas ki ganj-1-zar asan dihad babad Wa anki za ranj bi dirame ghussaha khurad Wa za dast rafta baz na ayad ba hich hal Chandanki u flghan kunad wa jamaha darad."

ANwar-I-SuheILI.

"Prize high a wished for object when 'tis won, Nor let it slip lest thou should'st feel regret, Full many a spendthrift when his gold is done Must under want's stern trials cashless fret, For ly-gone treasures back shall ne'er return, Though clothes be rent and hearts with anguish burn."

(EASTwick).

"Ma tuqaddimu lj'anfusikum min khairin tajiduhu "inda 'llahi."

KORAN, chap.

"Whatever good works ye send on for your own behoof ye shall find with God."

(RODWELL).

" Mauj-i-'ata shud padid, ghurrish-i-darya rasid,

Subh-i-sa'adat damid, subh na, nur-i-khudast."

Diwan-1-Shams-I-TAbriz.

" The billow of largesse hath appeared, the thunder of the sea hath arrived, The morn of blessedness hath dawned. Morn? No, 'tis the light of God." (NICHOLSON).

"Mautu 'ifuqara rahatun."

Arabic Proverb.

"The death of the poor is repose."

"Ma uthiru 'an yamtadda bi zamani

Hatta 'an 'ara daulate 'laughadi wa 'ssifali

Taqaddaman' 'unasun kana shutuhum

Wara khatwiya idh 'amshi 'ala mahali, Hadha jazau 'mar'in 'aqranuhu daraju Min qablihi fatamanna fusahata 'lajali."

Al Tughrai.

- Why have my days been stretched by fate

To see the vile and vicious great?

While I, who led the race so long,

Am last and meanest of the throng?

Ah, why has death so long delayed

To wrap me in his friendly shade,

Left me to wander thus alone,

When all my heart held dear is gone?"

J. D. Carlyle. 
" Maya-e-'aish-1-admi shikamast

Ta batadrif mi-rawad chi gamast."

Gulistan (Preface).

"The source of man's life is the belly,

So long as that acts regularly, what fear is there ?"

(Platro).

" Maya'e mardum chashmam za gunah shusta na shud

Garchi dar giriya du sad bar bar atish kardam,

Ta rihad z'atish farda'e qiyamat imruz

Binazr dar rukh-1-zisht-1-tu "azabash kardam."

Jami, BHinaristan, chap. 6 .

"The leaven of sin could not be washed out from the pupils of my eyes, Althougl I wept twice a hundred times over a fire ;

But to be saved from the fire of the resurrection, I to-day,

Punished them by contemplating thy hideous face." (REuatser).

"Maya'e taufiq karm kardan ast

Ganj yaqin tark diram kardan ast

Ganj rawanra ki tu pursi nishan

Nist bajuz anki ba bakhshi rawan."

ANIVAR+1.SUHEILI.

"The liberal brings God's favour on himself,

True treasure lies in the forsaking pelf,

Would'st thon the trace of ceaseless treasure find,

'Tis only in an ever-bounteous mind." EAstwick.

"Ma yakunu min najwa thalathatinilla huwa rabi'uhum wa la khamsatin illa huwa sadisuhum wa a 'adna min dhalika wa la 'akthara illa huwa ma'ahum 'ainama kanu." KORAN, chap. 58.

"Three persons speak not privately together but He is their fourth; nor five but He is their sixth; nor fewer nor more, but wherever they be, He is with them."

(KODWELL).

“Ma yastawa 'lbahrani, hadha 'adhbun furatun sa'ighun sharabuhu wa hadha milhun ujajun wa min kullin ta'kuluna lahman tariyyan wa tastakhrijuna hiliyatan talbisunaha, wa tara 'Ifulka fihj mawakhara litabtaghu min fadhlihi, wa la'allakum tashkuruna."

"The two seas are not alike; the one is fresh, sweet, pleasant for drink, and the other salt, bitter; yet from both ye eat fresh fish, and take forth for yourselves ornaments to wear; and thou seest the ships cleaving the waters that ye may go in quest of His'bounties; and haply ye will be thankful."

KORAN, chap. 35 .

"Ma ya'zubu 'an rabbika min mithqalin dharratin fl 'lardhl wa la fl 'ssamai wa la 'asghara min dhallka wa la 'akbara llla fl kitabin mubin."

Korsx, chap. 20. 
"Not the weight of an atom on earth or in heaven escapeth thy Lord;" nor is there aught that is less than this or greater, but it is in the perspicuous Book."

(RODWELL).

“ Ma yughna 'ththara 'ani 'lfata

Idha hashrjarat yauman wa dhaqa biha 'ssadar." Hatim AL TAI.

"Little use is wealth to a man when his throat rattles, and the breath leaves his chest."

D. S. Margoliouth.

"Mazan dar wadi makr wa hil gam

Ki dar dam-i-bala ufti sar-anjam."

ANWAR-I-Suheill.

" Do not into the vale of guile and fraud thy footsteps bend, For thou wilt fall into the snare of sorrow in the end."

EAsTwICK.

"Mazan laf bi kibri k'an az nishan pa'e mur

Dar shab tarik bar sang-i-siyah pinhantar ast

Wa za darun kardan birun asan ma gir anra k'az an

Kuhra kandan bisuzan az zamin asantar ast." Jami (Biharistan).

" Boast not of having no pride because it is more invisible

Than the mark of an ant's foot on a black rock in a dark night.

Think it not easy to extirpate from thy heart,

For it is more easy to root up a mountain from the earth with a needle."

(REHATSEK).

"Mihman-i-tu am dar saff arbab iradat

Bi nishasta, ba har chiz ki ayad za tu razi ;

Binihada bakhwan-i-karamat dida'e ummid

In'am tura muntazaram, na mutaqazi."

JAMI (BEHARISTAN).

"I am Thy guest in the ranks of those who wait upon Thy pleasure, Content with everything that proceeds from Thee;

Fixing on the table of Thy bounty the eyes of hope,

I wait for Thy blessings, and ask not imperiously for them."

Asiatic Jouknal.

" Mi-pursidi ki chist in nafs-i-majaz

Gar bar guyam haqiqatash, hast daraz,

Nafsist padid amada az daryaye

Wa angah shuda baq 'ar-i-an darya baz."

Omar Khayyam.

"You ask what is this life, so frail, so vain,

'Tis long to tell, yet I will make it plain,

'Tis but a breath blown from the vasty deeps,

And then blown back to those same deeps again."

(WHINFIELD). 
"Mihr pakan darmiyari dil nishan Dil ma dih illa ba mihr dil khushan; Kue naummedi maru ummidhast Suo tariki maru, khurshid hast."

JalalLudin Rusi.

"Then love the saints; their love plant deeply in thy heart,

The pure of mind alone deserve a pure love's part, Court not despair ; hope ever springs in human breast, Seek not the dark ; the sun of light shines full confest."

(RedHouse).

\section{" Mihtari dar qabul-1-firmanast \\ Tark-1-firman dalil-i-haramanast ; \\ Har ki sima-i-rastan darad \\ Sar-i-khidmat bar astan darad."}

Gulustan, chap. x.

"Greatness consists in bowing to God's will, Rebellion proves thee baffled, outcast still; Who bears inpressed the tokens of the just, Will place his head submissive in the dust."

EASTWICK.

" Millat 'ishq az hama dinha juda'st

Ashiqanra mazhab wa millat khuda'st."

Jalaliddin Rumi.

"The sect of lovers is distinct from all others, lovers have a religion and a faith of their own."

(WIINFIELD).

“ Min ayatihi 'llailu wa 'nnaharu wa 'shshamsu wa 'lqamaru la tasjudu lilshshamsi wa la lilqamari wa 's judu l'illahi 'lladhi khalaqahunna, in kuntum iyyahu ta "budun."

Koran, chap. 4 I.

"Among I Iis signs are the night and the day and the sun and the moon. Bend not in adoration to the sun or the moon, but bend in adoration before God who created them both if ye would serve Him."

RODWELL.

"Minhumu 'lladhina yu'dhuna 'nnabiyya wa yaquluna huwa 'udhunun, qul 'udhunu khairin lakum yuminu b'illahi, wa yuminu lilmuminin."

Koras, chap. 9.

"There are some of them who wrong the prophet and say 'He is all ear.' Say ' an ear of gond to you. He believeth in (iod and believeth the believers.'"

RODWELL.

“ Miras-i-pidr khwahi, 'ilm-i-pidr amuz

K'in mal-1-pidr kharch tawan kard badih ruz." Gu1.lsTds, chap. 7.

"Learn what thy father knew, if thou would'st hold

Ilis place. In ten days thou wilt spend his gold." 
" Mirihand arwah har shab za in qafs Farighan bi hakim wa mahkum kas, Shab za zindan bikhabar zindanian Shab za daulat bikhabar sultanian, Na gham wa andisha-e-sud wa ziyan $\mathrm{Na}$ khiyal in fulan wa an fulan, Hal arif in bud bi-khwab ham Guft izid ham raqud za in maram, Khufta az ahwal dunya ruz wa shab Chun qalam dar panja-e-taqlib Rabb."

Jalaludin Rumi.

" Every night spirits are released from this cage (the body) And set free, neither lording it nor lorded over, At night prisoners are unaware of their prison, At night kings are unaware of their majesty, Then there is no thought or care for loss or gain, No regard to such an one or such an one, The state of the ' knower' is such as this even when awake God says ' Thou would'st deem him awake though asleep,' Sleeping to the affairs of the world day and night Like a pen in the directing hand of the writer." (WIINFIELD).

“ Miskin dil-i-dardmand-i-diwana'e man

Hushyar na shud za ishq-i-janana'e man

Ruze ki sharab-i-ashiqe midanad

Dar khun-i-jigar zadand paimana'e man."

OMaR KhaYyam.

"My heart weighed down by folly, grief and tine, Is e'er inebriate with love divine;

When as the Loved One portioned out $\mathrm{His}$ wine,

With my heart's bloo] He filled this cup of mine."

(WHINFIELD).

"Miskin-i-haris dar hama 'alam hami dawad

U dar qafa'e rizq wa ajal dar qafa'e u."

Gulistan, chap. 8.

" Poor greedy wretch! where'er he drags himself Death him pursues, while he's pursuing pelf."

(EAsTwick).

"Miskin khar agarchi bi tamizast,

Chun bar hami barad, 'azizast;

Gawan wa kharran-i-barbardar

Bih az admian-i-mardum-azar."

Gulistan, chap. z.

"True, the poor ass is dull; but then

For carrying loads, 'is dear to men.

The carrier ox, the patient ass

Man's tyrant, cruel man surpass."

EASTWICK. 
" Mis-1-hastlyat chu Musa na za kimiyash zar shud? Chi gham ast, agar chu Qarun, bajuwal zar na dari? Ba dirun-1-tu'st Misre ki tu'i shakar sitanast Chi gham ast, agar za birun madad-i-shakar na dari?"

DiWAN-1-ShAMS-I-TABRIZ.

"Has not the copper of your existence been changed, like Moses to gold by his alchemy,

What matter though you have no gold in a sack like Qarun?

Within you is an Egypt and you are its garden of sugar-canes,

What matter though you have no supply of sugar from without?"

Nicholson.

“Miyana'e tarafain az sifat chandani

Tafawatast kl az aftab ta basuha

Pas ikhtiyar wasat ra'st dar Jam'i amur

Bad'an dalil kl khairu 'l'amur ausataha."

Anwak-1-SuHEILI.

" Extremes of quality as separate are As the bright sun and the obscurest star ; Wherefore to choose the midmost thing is best, Since all 'the Golden Mean' as true attest."

(EASTWICK).

"Miyana'e tu wa an ki zaban zadi zakhmash

Baghair suhbat-i-sang wa sabu na khwahad shud, Jarahate ki za tigh-i-zaban rasad ba dile

Ba hich marham rahat niku nakhwahad shud."

ANWAR-H.SUheILI.

"Both thou and they who from thy sarcasms smart, Will be such comrades as the stone and cup.* The wound the tongue inflicts upon the heart No soothing ointment ever can close up."

EAstwick.

“Miyan du tan jang chun atish ast

Sukhan chin badbakht haizam kash ast.". Bostan of S'ADi, chap. 7.

" Contest between two persons is like fire, The unfortunate tale-bearer is the fire-wood cutter."

(CLARKE).

"Miyan-1-k'aba wa but-khana hich farqe nest Ba har taraf ki nazar mi-kuni barabar u'st."

" Between the Kaaba and the wine-house no difference I see, Whate'er the spot my eye surveys, there equally is He."

BickNelL.

“Miyan-i-sad kas ashiq chunan padid ayad

Ki bar falak mah-i-taban miyan-1-kaukabha."

DiWAN-1-Shams-1-TABRIz.

* i.e., of glass. 
"The lover shineth among his fellows as in heaven

The brilliant moon among the host of stars." (Nicholson).

"Miyan-i-u ki khuda afrida ast az hich

Daqiqa ast ki hich afrida nakshadat,

Gada' $\Theta$ kui tu az hasht khuld mustaghnist

Asir-i-band-i-tu az har du "alam azadast."

HAFIZ.

\& The connection with Him which God out of nought hath created,

Is a subtlety which no created being hath solved;

Independent of the eight abodes of Paradise is the beggar of thy street, Free of both worlds is thy bound captive."

"Mur gard award ba tabistan

Ta faraghat buwad zamistanash."

Gulistan, chap. 7.

"The ant in summer corn upheaps,

"Tis thus in winter with abundance fed." (EASTwICK).

"Mur ki ba kaghaz did u qaiam

Guft ba mur digar in raz ham

Ki ajaib nagshaha an kalak kard

Hamchu rihan wa chu susan zar wa ward;

Guft an mur asb'a ast an pishawar

Wa in qalam dar f'al far'a ast wa asr ;

Guft an mur seyam az bazu ast

K'asb'a laghar za zurash naqsh bast ;

Hamchunin miraft bala ta yake

Mihtar mur an fatan bud andake

Guft k'az surat na binid in hunar

Juz ba aql wa jan na jumbad naqshaha."

Jalaluddin Rumi.

"An ant who saw a pen writing on paper

Delivered himself to another ant in this way:

'That pen is making very wonderful figures

Like hyacinths and lillies and roses,'

The other said ' The finger is the real worker,

The pen is only the instrument of its working;'

A third ant said, 'No! the action proceeds from the arm,

The weak finger writes with the arm's might;'

So it went on upwards, till at last

A prince of the ants who had some wit

Said, 'Ye regard only the outward form of this marvel,

It is only from reason and mind that these figures proceed."

(WHINFIELD).

“ Mur shahwat shud za adat hamchu mar

Mar-i-shahwat ra bikash dar ibtida;

Warna inak gasht marat azhdaha

Lek har kas mur binad mar-i-khwish

Tu za sahib-i-dil kun istifsar-i-khwish."

JALALUdDin RUMi. 
"The ant of lust becumes by' habit like a snake, Slay first of all the snake of your lust, Else this snake of yours will become a dragon ; But every one regards his own snake as an ant, Go inquire of your true state from a man of heart."

" Mu'allim niyamukht fahm wa rae Sarisht-i-in sifat dar wujudat khuda'e ; Garat man'a karde dil-i-haqq niwash Haqqat 'ain-i-batil namude ba gush."

Bostan of S'ADI.

" The instructor taught thee not understanding and judgment, God created these qualities in thy existence;

If $\mathrm{He}$ had refused thee a heart truth-hearing,

Truth would have appeared to thy eye the essence of falsehood."

"Mubtila'e ba gham wa mihnat wa anduh-i-firaq

(CLAKKE).

Fy dil in nala wa afghan-i-tu bi chize nest ;

Dush bad az sar-i-kuyash ba gulistan biguzasht

Ey gul, in chak-i-giriban-i-tu bi chize nest."

HAFIZ.

"With the grief, the pain, the sorrow of separation, thou art distressed, $O$ heart ! this thy wailing and lamenting without something is not, Last night from the head of his street the wind passed to the rose-garden, $\mathrm{O}$ rose ! this rent of thy collar without something is not." (CLARKE).

"Muddate shud k'atish-i-sauda'e-u dar jan-i-ma'st Z'an tamannaha ki da'im dar dil-1-wiran-1-m'ast."

HAFIZ.

"An age has passed since the fire of passion for him was in our soul, Through that desire that was in the desolate heart." (CLARKE).

"Muflisan gar khush shawand az zar-i-qalb

Lek an ruswa shawad dar dar-i-zarb

Ta zar andudiyat az rah n'afgand

Ta khujal kazh tura chah n'afgand." .

Jalaluddin Rumi.

"A pauper may amused be with counterfeited coin, But take this to the mint; defaced 'twill be in fine; Then be not thou misled with gilded counterfeit, Delusion will thee plunge headlong into hell's pit."

"Muhal ast agar sar bar in dar nihi

REDHOUSE.

KI baz ayadat dast-i-hajat tihi ;

Khudaya, muqassar bikar amadim,

Tihidast wa ummidwar amadim."

Bostan of S'Adi.

"It is impossible if thou prostrate thyself at God's threshold that the hand of thy need should return empty,

O God! we are come to thee deficient in every good deed empty-handed, yet trustful we are come."

Asiatic Jour.val. 


\section{"Muhammad k'azal ta abad har chi hast \\ Ba araish nam-i-u naqsh bast Chiraghe ki anwar biniash badu'st Farugh hama afrinish badu'st."}

AnWAR-1-SuheILI.

"From past eternity to the unending future 'tis

Muhammad's name that gilds whatever is,

Sole lamp is he whence beams of splendour shine, In him creation's splendours all combine." EAsTwICK.

"Muhammadun rasulu 'llahi w'alladhina ma'ahu 'ashidau 'ala 'Ikaffari ruhamau bainahum, tarahum rukk'aan sujjadan yabtaghuna fadhlan mina'llahi wa ridhwanan, simahum fi wujuhihim min athari ssujudi, dhalika mathaluhum fi 'taurati wa mathaluhum fl 'linjili, kazar'in 'akhraja shatahu fazarahu, fa 'staghladha, f'astawa 'ala suqihi, yu'jibu 'zzurra'd, liyaghidha bihimu 'l kuffara."

KoRAN, chap. 48. $v \cdot 79$

"Muhammad is the Apostle of God; and lis comrades are most vehement against unbelievers, but full of tenderness among themselves. Thou mayest see them bowing down, prostrating themselves, imploring favours from God and his good pleasure in them. Their tokens are on their faces, the traces of their prostrations. This is their picture in the Law and their picture in the Evangel. They are as the seed which putteth forth its stalk; and strengtheneth it, and it groweth stout and riseth upon its stem rejoicing the sowers, to incense the unbelievers by their means."

" Muhiyya kunad ruza'e mar wa mur

(RODWEL1.).

Wagar chand bi dast wa pae and wa zur

Bi amrash wujud az 'adam naqsh bast

Ki danad juz u kardan az nist hast?

Na bar auj zatash para murgh-i-wahm

Na dar zail-i-wasfash rasad dast-i-fahm."

Bostan of S'ADI.

" He prepares the daily food of the snake and the ant, Although they are without hands and feet and strength, $\mathrm{By} \mathrm{His}$ order He portrayed existence from non existence Who except Him knows how to make the existing from the non-existing? The bird of fancy flies not to the summit of His nature, The power of the intellect arrives not at the skirt of His description."

"Muhsinan murdand wa ihsanaha bamand, (ClakKe).

Ey khunuk an ra ki in markab barand ;

Zaliman murdand wa manad an zulmaha

W'ai jane $\mathrm{k}^{\prime} \mathrm{u}$ kunad makar wa dagha."

JALALUdDin Rum.

"The generous die but their kindness remains,

O happy he who drove this chariot (of kindress),

The unjust die and their injustice remains,

Alas for the soul that commits deceit and fraud." 
" Muhtaj-i-qissa ntst garat qasd-1-jan-i-ma'st

Chun rakht azan-i-t'ust ba yaghma chi hajatast?

Jam-i-jahannuma zamir-i-munir-i-dust

Izhar-i-ihtiyaj-i-khud an ja chi hajatast?"

HaFiz.

"If intention be Thine against our life, there is no need of pretence,

When the chattels are thine, of plunder is what need?

The cup world.displaying is the luminous mind of the friend of God,

Then of the revealing of my own necessity is what need?" Clarke.

" Mui sufed az ajal arad paiyam

Pusht kham az marg risanad salam,"

ANwar.1-Suheil.

"The white hair comes, its message gives from fate and terror's king,

And the crooked back and stooping form death's salutation bring."

EAsTWICK.

"Mujarrad rau wa khana pardaz bash

Jawanmard wa dunya bar andaz bash."

Bostan of S'ADI.

"Go alone, and be house emptying;

Be liberal and wealth-dispensing."

Clarke.

" Mujrim gar in daqiqa badanad ki dambadam

Mara chi lazzat ast ba 'afu gunahgar

Hamwara irtikab juraim kunad ba'amd

Daim ba nizd-i-ma gunah arad ba "itizar."

ANWAR-1-SUheILI.

"Did the offender know what bliss to me

Arises from the pardon of a sin,

He'd ever err intentionally,

And with excuses some new crime begin." Eastwick.

" Mujrim kushta'e af"al-i-khwish ast

Chu bue afu yabad, zinda gardad ;

Agar surat pazirad paikar-i-afu

Chu mihr wa mushtari tabdih gardad."

ANWAR+1-SUhriLI.

" Their own bad actions do the guilty slay

The scent of pardon lifts them from the grave;

Could we in outward shape sweet mercy see,

Than Sun or Jupiter more bright she'd be." EAstwick.

"Mukhalifat-i-muzi ba malash ma kun

Ki bikhash bar awrad bayad za bun;

Makun sabr bar 'amil-i-zulm dust

Chu az farbihi bayadash kand pust.

Sar-i-gurg ham awwal burid

Na chun guspandan-i-mardam darid."

Bostan of S'ADl. 
" Exercise not retribution against the despoiler by confiscation of his property,

But it is proper to destroy his root from the foundation.

Exercise not patience with the agent of the friend of tyranny,

Since on account of his fatness (from extortion) it is proper to flay his skin.

It is also proper at first to cut off the wolf's head

Not at the time when he tore in pieces the sheep." Clarke.

" Mukhalif-i-tu yake mur bud wa mare shud

Bar awar az sar an mur mar gashta damar

Madih zamanash az in bish wa ruzgar ma bar

Ki azhdaha shawad ar ruzgar yabad mar."

ANwak-1-SuheIL,

" Thy foe was but an ant, a serpent now is he !

Then on this snake-turned ant take vengeance now.

For soon this serpent will a mighty dragon be,

If thou delay and him to live allow."

EASTWICK.

" Mukhalifu 'l'aiyyam zidd taba'aha

Mutatlab fl 'lma jadhwata narin,

Wa idha rajauta 'Imustahilan fa 'innama

Tabna 'Iraja 'ala shaflr harin

Fa 'l'aishu nauman wa 'lmuniyatu aiqadhuhu

Wa'l maru bainahuma khiyalu sarin."

Ali bin Muhammed Al Tahamy.

" Believe not Fate at thy command

Will grant a meed she never gave ;

As soon the airy tower shall stand

That's built upon a passing wave.

Life is a sleep of threescore years,

Death bids us wake and hail the light,

And man with all his hopes and tears

Is but a phantom of the night."

J. D. Carlyez.

"Mukhannas bih az mard-i-shamshir zan

Ki riz-i-wagha sar batabad chu zan."

Bostan of S'Adi.

"An impotent one is better than the swordsman,

Who, in the battle-day turns away his head woman like."

"Mulkat-i-ashiqe wa kunj-i-tarab

Clarke.

Har chi daram zi yumni daulat-i-u'st."

HAF1Z.

"The realm of being a lover and the corner of joy,

All I have is from the favour of the fortune of His."

"Mulk-1-'uqba khwah k'an khurram buwad

Clarke.

Zarra'e z'an mulk sad 'alam buwad,

Jahd kun ta dar miyan in nishast

Zarra'e z'an 'alamat ayad ba dast."

ANWAR-1-SUheill. 
"Seek then the world to come for joys are there !

Not with its smallest portion could compare

A hundred worlds ; then strive, where now thou art

To win of that more happy world a part." EAsTwick.

"Mulk-i-sarasar zamin

Na-arzad kd khune chakad bar zamin."

Bostan OP S'ADI.

"The country of the whole earth

Is not worth one drop of blood that trickles on the earth."

(ClakKe).

"Mulku 'Iqana'ati la yukhsha 'alaihi, wa la

Yuhtaju fihi 'ila 'l'ansari wa 'lkhawali,

Tarju 'lbaqa bidarin la thabata laha

Fahal sam'ita bidhillin ghairi muntaqaiin?"

Al TUahrat.

"Contentment's realms no fears invade, No cares annoy, no sorrows shade, There placed secure, in peace we rest, Nor aught demand to make us blest. While pleasure s gay fantastic bower, The splendid pageant of an hour, Like yonder meteor in the skies Flits with a breath no more to rise."

J. D. Carlyle.

"Muminanra burd bashad 'aqibat

Ba munafiq mat andar akhirat;

Garchi har du bar sar-i-yak bazi and

Lek baham Maraghzi wa Raziand ;

Har yaki sue maqam-i-khud rawad

Har yaki bar wafq-i-nam-i-khud rawad."

JALALUDDIN RUM.

"Victory falls to the believers at last,

The hypocrites have death in the next world.

Although both parties are engaged in one game,

Yet, as regards one another, they are inhabitants of Merv and Rai (i.e., far asunder),

Each goes to his own place,

Each fares according to his name."

(Nicholson.

" Munaghghas buwad "aish-i-an tandurust

Ki bashad ba pahlawi bimar sust

Chu binam ki darwish-i-miskin na khwurad

Bigam andaram luqma zahr ast wa dard."

Bostan of S'ADI.

"The enjoyment of him that is sound in health is troubled, by whose side is stretched the enfeebled victim of disease ;

When I see that the poor Darwesh has not eaten, the morsel turns on. my own palate to poison and pain."

(FALCONER). 
"Murghe ki khabar na darad az ab-i-zilal Minqar dar ab-i-shur darad hama sal."

AKHLAQ-I-MUHSINI.

"The bird who has no knowledge of sweet water

Dips his beak all the year in the water that is salt."

"Murghe ki ramida gardad az dam

Min b'ad ba dana kai shawad ram."

KeEne.

"The bird once scared that has escaped the net, Will for no grain its terror then forget." (EAsTwICK).

"Murgh-i-bagh-i-malkutam nayam az alam-i-khak

Du sih ruze qafse sakhta and az badanam." Diwan-1-Shams-1-Tabriz. .

"I am a bird of the beavenly garden; I belong not to the earthly sphere, They have made for two or three days a cage of my body."

"Murgh-i-dilam tair ast qudsi-i-'arsh ashiyan (NICHOLSON).

Az qafs-i-tan malul, ser shuda az jahan, Az sar-i-in khakdan chun biparad murgh-i-jan

Baz nishiman kunad bar dar-i-an astan;

Dar du jahanash makan nist bajuz fauq-i-charkh Jism-i-way az m'adan ast, jan-i-way az la makan."

HAFIZ ODE, 465.

" My soul is as a sacred bird, the highest heaven its nest, Fretting within the body's bars it finds on earth no rest.

When, speeding from this dusty heap, this bird of mine shall soar, 'Twill find upon yon lofty gate the nest it had before,

No spot in the two worlds it owns-above the sphere its goal ;

Its body from the quarry is, from No-place is its soul."

"Murgh-i-himmat chu bal bikushayad

BiCKNELL.

'Az wa lqbalash ashiyan bashad

Pish-i-chaugan-i-himmat-i-'ala

Kamtarin gue asman bashad."

Akhlaq-i-Muhsini.

"When the bird of ambition expands her wings,

Honour and success are her nest ;

Before the bat of a lofty mind,

The sphere of heaven is the smallest ball." KEENE.

“Murghra par miburd ta ashiyan

Par mardam himmatast ey marduman

Ashiqe k'aluda shud dar khair wa sharr

Khair wa sharr mangar, tu dar himmat nigar.

Baz agar bashad supid wa bi nazir,

Chunki saiadash mush bashad, shud haqir;

War buwad chaghde wa mail-i-u ba shah

U sar baz an ast, mangar dar kulah."

JALALUdDin Rumi. 
"A bird flies with its wings towards its nest, The wings of a man are his aspiration and aim.

If a lover be befouled with good and evil

Yet regard not these; regard rather his aspiration,

Though a falcon be all white and unmatched in form,

If he hunts mice, he is contemptible and worthless,

And if an owl fixes his affection on the king,

He is a falcon in reality ; regard not his outward form."

WIINFIELD.

" Muridan ba quwat za tiflan kam and

Mushaikh chu diwar-i-mustahkam and."

BOSTAN OF S'ADI.

"The disciples are in strength less than children,

The sheikhs are like a strong wall."

(Clarke).

"Musallat makun chun mane bar saram

Za dast-i-tu bih, gar 'aqubat baram."

Bostan of S'Adi, chap. so.

"Make not a person, like unto myself, ruler over me,

If I bear punishment, it is best from thy hand." (Clarke).

"Mushahadata 'l'abrar baina 'tajalli wa 'l'istatar."

Gulistan, chap. 2.

"The vision of the pious is between effulgence and obscurity."

" Mushk alud 'ast amma mushk nai

(EAsTivick).

Bui mushkastash wale juz pashk nai

Taki pashke mushk gardad, ey murid,

Salha bayad dar an rauza charid."

JAI.ALUDdiN RUM.

" He is only scented with musk, he is not himself musk,

He smells of musk, but is really naught but dung,

For his dung to become musk, O disciple,

He must graze year after year in the divine pasture."

(WHINFIEI.D).

" Mushkil-i-khwish ba pir-1-mughan burdam dush

K'u ba ta'id-i-nazar-i-hall-i-mu'amma mi-kard

Didamash khurram wa khandan qadah-e-bada ba dast

Wa andar an aina sad guna tamasha mi-kard

Guftam 'In jam-i-jahan bin batu ki dad hakim?'

Guft 'An ruz ki in gumbad-i-mina mi-kard.' "

HAF12.

" Last eve unto the Magian Sheikh to solve my doubts I flew,

To him who by his piercing gaze to secrets found the clue,

I saw him smiling and content, the wine-cup in his hand,

And in its world-revealing glass a hundred things he scanned,

I said 'When gave the Lord All.Wise that wondrous cup to thee?'

He said "When the enamelled Dome was formed by His decree."

BICKNELL. 
"Mushtari khwahi ki az wai zar bari, Bih za haqq kai bashad, ey jan, mushtari?

Mikhirad az malat ambae najas,

Midihad nur zamir muktabas

Misitanad in najas jism fana,

Midihad mulki birun az wahm-i-ma,

Misitanad qatre chande az ishk,

Midihad kausar ki arad qánd rishk."

JALALUDDIN RUMi.

"Seek ye a purchaser who will pay you gold,

Where will you find one more liberal than God?

He buys the worthless rubbish which is your wealth, He pays you the light that illumines your heart, IIe accepts these frozen and lifeless bodies of yours And gives you a kingdom beyond what you dream of, He takes a few drops of your tears

And gives you the divine fount sweeter than sugar."

"Musiya! adab danan digarand

(WHINFIELD).

Sukhta jan wa rawanan digarand

Gar khata guyad, u-ra khate magu

Gar shawad pur khun, shahidan ra mashu.

Khun shahidanra az ab aulatar ast,

In khata az sad sawab aulatar ast."

JALALUDDIN RUMI.

"O Moses! the lovers of fair rites are one class,

They whose hearts and souls burn with love are another,

If they speak amiss, call them not sinners,

If a martyr be stained with blood, wash it not away,

Blood is better than water for martyrs,

This fault is better than a thousand correct forms."

"Musalmanan, mara waqte dile bud

WHINFIR.LD.

Ki ba wai guftami gar mushkile bud,

Dile hamdard wa yare mashlahat bin

Ki istizhar-i-har ahl-i-dile bud

Za man za'i shud andar kue janan."

HAFIZ,

"O Muslims once a heart was mine

Whereto I used to speak if there was a difficulty ;

A heart fellow-sufferer, helper, counsel-perceiver,

That was the aid-seeker of men of heart;

But in the Beloved's street the heart was lost to me."

" Musulman gar bi-danisti ki but chist

Bi-danisti ki din dar but parastist."

SHABISTARI.

" Did the Musulman understand what the Idol is,

He would know that there is religion even in idolatry."

(E. G. BrownE). 
" Mutakallimra ta kase 'aib na girad, sukhanash salah na pazirad."

Gulistan, chap. 8.

"Until one points out to an orator his defects, his discourse will never be mended."

(EASTWICK).

"Mutrib bisaz 'ud ki kas bi ajal namurd

Wa an ku na in tarana sarayad, khata kunad."

"Sing, minstrel, to thy lyre the strain unfated no one dies, Whoever cannot sing this lay in sinful error lies." BICKNELL.

" Muzhda'e-wasi-i-tu ku? K'az sar-i-jan bar khizam Ta'ir-i-kuds-am va az dam-i-jihan bar khizam."

HAFIz.

"Where is the good tidings of union with Thee? For I will rise up with my whole heart ;

I am a bird of Paradise, and I will soar upwards from the snare of the world."

(E. G. BROWNE).

"Muzhda dadand ki bar ma guzri khwahi kard Niyyat-i-khair magzaran ki mubarak fal ast."

HAFIZ.

" Glad tidings they gave that Thou wilt pass by us, Change not Thy good resolve, for a happy omen it is."

(CLARKE).

"Muzhda ey dil ki digar bad-i-saba baz amad, Hudhud-i-khush khabar az taraf-i-Saba baz amad, Bar kash ey murgh-i-sahar nagma'e Daudi baz Ki Sulaiman-i-gul az taraf-i-hawa baz amad."

HaF12.

"O heart ! glad tidings! for the morning breeze hath come back !

Fron the quarters of Saba the lapwing of good news hath come back, O bird of the morning prolong the melody of David,

For from the quarter of the air the Sulomon of the rose hath come back."

(CLARKE).

"Muzhda! muzhda! nak hami-ayad bahar

Ta buwad taban shigufa chun zirih;

Ta kunand an mewaha paida girih;

Chun shigufa rikht mewa sar kunad

Chunki tan bishkast jan sar bar kunad."

"Good news! Good new ! Lo! the spring is at hand, If the blossoms did not shine as bright helmets, How could the fruits display their globes?

When the blossoms are shed, the fruits come to a head, When the body is destroyed, the soul lifts up its head."

WHINFIELD. 
"Na abistan durr buwad har sadaf Na har bar shatir zanad bar hadaf."

"Not every oyster is pregnant with the pearl,

Not every time does the expert archer hit the butt."

(Clakke).

" Na an ki bar dar-i-dawa nishinad az khalqe

Wa gar khilaf kunandash ba jang bar khizad, Agar za kuh faru ghaltad asia sange

Na arifast ki az rah-i-sang barkhizad."

Gulistan, chap. 2.

" Not at strife's door sits he ; when thwarted, ne'er

Starts up to contest; all unınoved his soul,

$\mathrm{He}$ is no saint who from the path would stir

Though a huge stone should from a mountain roll."

EASTWICK.

"Na ba dawa'ist qadr wa qimat-i-mard

Qimat-1-mard sabr bayad kard."

AKHLAQ-I-MUHSINI.

"The merit and value of a man are not according to his pretensions, His worth should be determined by his patience."

(KEENE).

"Na bar auj zatash parad murgh-i-wahm

Na dar zail wasfash rasad dast-i-fahm;

Dar in warta kishti faru shud hazar.

Ki paida na shud takhta'e bar kinar."

Bostan of $\mathbf{S}^{\prime}$ Adi.

"The bird of fancy flies not to the summit of His nature,

The power of the intellect arrives not at the skirt of his description,

In this whirlpool a thousand ships of reason foundered

In such a way that not a plank was found on the marge." (Clarks).

"Na bar ushture sawaram na chu astar zir-i-baram

Na khudawand-i-r'aiyat na ghulam-i-shahriyaram

Gham maujud wa parishani m'adum na daram

Nafsi mizanam asuda wa umari basar aram." Gulistan, chap. 2.

"I ride not on a camel, but am free from load and trammel,

To no subjects am I lord, and I fear no monarch's word;

I think not of the morrow, nor recall the bygone sorrow

Thus I breathe exempt from strife, and thus moves on my tranquil life."

(EASTWICK).

"Na bayad bastan andar chiz wa kas dil Ki dil bardashtan karist mushkil."

Gulistan, chap. 5 .

" Thy heart from loving thing or person guard, For to recall affection is most hard."

EASTWICK. 
"Na bayad shud ba hast wa nist khushnud

Dar in hasti ki yabad nisti zud

Chashanad ab wa bar atish nishanad

Babakhshad chiz wa angah wa sitanad

Dihad blsitanad wa are nadarad

Ba Juz dad wa sitad kare nadarad."

ANwar-I.SUheILI.

"In this existence so soon to expire,

The being or not being should not make us gay,

It gives us water, puts us in the fire,

Freely bestows a thing then snatches it away,

It gives, it snatches back and has no shame,

Taking and giving, its task is this the same." EAstwick.

" Na binad mudd'ai juz khwishtanra

Ki darad parda pindar dar pish ;

Garash chashm-1-khuda bini ba bakhshad,

Na binad hich kas "ajiztar az khwish."

Gulistan, chap. 2.

" Naught but themselves can vain pretenders mark

For conceit's curtain intercepts their view ;

Did God illume that which in them is dark,

Naught than themselves would wear a darker hue."

(EAstivick).

"Na binand juz nek khuyan bihisht

Ba duzakh burd mard-ra khue zisht."

Bostan OF S'ADI chap. 4

"Those of good temper only see Paradise,

A bad temper takes a man to hell."

(Clarke).

"Na bini ki chun baham ayand mur,

Za shiran-i-jangi bar arand shur?"

Bostan of S'ADr, chap. I.

"Dost thou not see that when ants assemble together

They bring trouble and torment to fighting lions?"

(Clarke).

" Na bini ki chun gurba ajiz shawad

Ba arad ba changal chashm-i-palang."

Gulistan, chap. I.

" Seest thou not how in last extremity

The cat will lacerate the leopard's eyes." (EAstwick).

" $\mathrm{Na}$ bulbul bar gulash tasbih khanast

Ki har khare ba tasbihash zabanast."

Gulistan, cbip. 2.

"Not sole, the rose-couched Bulbul hymns his name, Each thurn's a tongue his marvels to proclaim."

“ Na burda ba subh dar talab shame chand

EAstrick.

Nanhada za khwishtan birun game chand,

Dar kiswat-i-khass amada 'ame chand

Badnam kuninda'e nikuname chand."

Omar Khayyan. 
"These dullards never burn the midnight oil In deep rescarch, nor do they ever toil To step beyond themselves but dress them fine, And others' reputation try to spoil."

WHINFIELD.

" $\mathrm{Na}$ burda ranj ganj muyassar na shawad Mazd an girift, jan biradar, ki kar kard."

ANWAR-I-Suheili.

"Who bears not toil, will ne'er the treasure gain, His is the guerdon, brother, whose the pain." EASTwICK.

“ $N a$ chandan bikhur k'az dihanat bar ayad

Na chandan ki az z'uf janat bar ayad.".

Gulistan, chap. 3 .

" Eat not so as to cause satiety,

Nor yet so little as of want to die." EAstwick.

"Nadanad kase qadar-i-ruz-i-khushi Magar muze uftad bisakhti kashi."

Bostan of $\mathrm{S}^{6} \mathrm{ADI}$, chap. 8.

"A person knows not the value of a day of pleasure, Save on that day when he falls to hardship enduring."

(Clarie).

"Na danisti ki bini band bar pae

Chu dar gushat mamad pand mardum?

Digar rah gar na dari taqat-i-nish

Makun angusht dar surakh-i-kazhdum."

Gulistan, chap. r.

" Knewest thou not that thou would'st see the chains upon thy feet,

When a deaf ear thou turnedst on the counsels of the wise ;

If the torture of the sting thou canst not with courage meet,

Place not thy finger in the hole where the sullen scorpion lies."

(EASTWICK).

"Na darad khiradmand az faqr 'ar

Ki bashad nabira az faqr iftikhar."

Pandnama of $S^{\prime}$ Adi.

"The wise man reckoneth not poverty any dishonour Since poverty was the Prophet's glory."

GLauwin.

"Nadarim ghair az tu faryad ras

Tu'i 'asiyanra khata bakhsh wa bas

Nigahdar mara az rah-i-khata

Khata dar guzar wa sawabam numa."

Pandnama of S'adi.

"We have none excepting Thee for our defender, Thou art the all-sufficient forgiver of transgressors, Preserve us from the road of sin, Pardon our misdeeds and instruct us in righteousness."

(GladWIN). 
" $\mathrm{Na}$ dida'1 ki chl sakhti hami rasad kase

Kl az dihanash badar mi-kunand dandani?

Qiyas kun ki chi halash buwad dar an sa'at

Ki az wujud-1-azizash badar rawad jani."

Gulistan, chap. 6.

" Hast thou ne'er marked his agony,

Out from whose jaw a tooth is wrenched?

Then think what must his feelings be

Whose life, dear life, is heing quenched."

" Nadimtu nadamata 'lkusayy lama

(EAstwick).

Ghaddat minni muttalaqatan Nawaru,

Wa kanat jannati, fakharajtu minha,

K'Adam hina 'akhrajahu 'adiraru;

Fakuntu kafaqin 'ainaihi 'amdan,

Fa 'asbaha ma yadhau 'nnaharu."

FARAZdAK.

"I fecl a repentance like that of $\mathrm{Al}$ Kosai, now that Nawar has been put away by me;

She was my Paradise and I have left her, like Adam when Ad Dirar drove him forth,

I have been as one who put out his eyes wilfully; who rises in the morning and the sun shines not to him." (CHENERY).

" Nadim wa mutrib wa saki hama ust

Khujal-i-ab wa gil dar rab bahana

Wujud-1-ma mu'amma'ist, Haflz

Ki tahqiqash fusunast wa fasana."

HAFiz ODE, 487 .

"Companion, minstrel, Saki,-all is He,

As the way's phantom clay and water see :

Man is a riddle and but vain pretence

Is his, O Hafiz, who would solve its sense." Bicknell.

s' Nafakh sur amr ast az yazdan pak

KI bararid ey zara'ir sar za khak

Baz ayad jan har yak dar badan

Hamchu subh hush jan andar badan

Jan tan khudra shinakht waqt ruz

Dar kharaba khud dar ayad chun kanuz." (Jalaluddin Rumi).

" The blast of the last trump will be God's command

To every atom to lift its head from the earth,

The souls also of each will return to their bodies,

Even as sense returns to bodies awaking from sleep,

On that morn each soul will recognise its own body

And return to its own ruin like hidden treasure."

4 Nafsat basag-i-khana haml manad rast

(WhiNfield).

Juz bang-1-miyan tibi az u bich nakhwast,

Ruba sifatast wa khwab khargush dihad

Ashub-i-palang darad wa gurg daghast."

Omar Kuayyam. 
" Men's lusts like house-dogs still the house distress With clamour, barking for mere wantonness : Foxes are they and sleep the sleep of hares, Crafty as wolves, as tigers merciless."

(WhiNFIELD).

“ Na giti pas az jumbish aram yaft?

Na S'adi safar kard ta kam yaft?

Dil az bi-muradi bifikrat masuz, Shab abistan ast, ey biradar, biruz."

Bostan of S'Adi, chap. 6.

" Did not the world find rest after motion?

Did not S'adi travel till he found his desire?

Consume not thy heart from failure of desire;

$\mathrm{O}$ brother, the night is pregnant with the day."

"Naguyand az sar-i-bazicha harfe

Clarke.

K'az an pande na girad sahib-i-hush ;

Wa gar sad bab-i-hikmat pish-i-nadan

Bikhwanand ayadash bazicha dar gush." Gulistan, chap. 2.

" Not e'en in jest a playful word is said,

But to the wise 'twill prove a fruitful theme,

To fools a hundred chapters niay be read

Of grave import ; to them they'll jesting seem."

(EASTWICK).

"Na gufta, na darad kase ba tu kar

Wa lekin chu gufti, dalilash biyar."

Gulistan, chap. 4 .

"Art silent? None can meddle with thee. When Thou once hast spoken, thou must prove it then."

EASTWICK.

"Na har chi ba qamat mihtar ba qimat bihtar, ashshatu nazifatun w'alflu jifatun."

Gulistan, chap. $x$.

"Not everything that is higher in stature is more valuable; the sheep. is clean and the elephant unclean."

(EASTWICK).

"Na har ki chihra bar afrukht dilbare danad,

Na har ki aina sazad, Sikandare danad,

Na har ki kulah kaj nihad wa tund nishast

Kulah dari wa ain-i-sarwari danad."

HAFIZ ODE, 2 II.

" Not every one whose face is bright, true love's ensnaring knows,

Not every one who mirrors makes, Iskandar's bearing knows,

Not every one who slants his cap or takes his seat augustly,

To wear the cap of sovereignty or rule us justly knows."

“ Na har ki quwwat-i-bazu wa mansabe darad

(BICKNELL).

Ba sultanat bikhurad mal-i-marduman baguzaf;

Tawan ba halq faru burdan ustukhwan-i-durusht

Wali shikam badarad chun bagirad andar naf." Gulistan, chap. I. 
"Not every one who with strong arm bears sway,

Can boast of his extortions in the end ;

To swallow the rough bone thou may'st some way

Devise; but once permit it to descend

Down to the navel, 'twill thy belly rend." (Eıstwick).

“Nahnu banu 'lmauta, fama baluna na'afu ma la budda min shurbihi

Tajkhalu eydina bi 'arwahina 'ala zamanin hla min kasbihi

Fahazihi 'l'arwahu min jawwihi wa haza 'lajsadu min turbihi

Lau 'afkard 'lashiqu fl muntaha husni 'lladhi yasbihi, lam yasbihi

Lam nara qarna 'shshamsi fl sharqihi fashakkati 'lanfusu fl ghar bihi."

MutanNabi.

"We are the sons of the dead, why then loathe the draught that must needs be drained,

We stint to time our souls though they be Ilis due, for these souls are air of $\mathrm{His}$ air, and these bodies are dust of His clust.

If the lover bethought himself of what would be the end of the beauty that entrances him, it would not entrance him,

Yet when we see the bursting forth of the rising sun, our minds doubt not of his setting."

(STEINGASS).

“Nahnu ruhani halalna badana

Fa 'idha absaratani 'absartahu

Wa idha absartahu 'absartana."

Manser hallaj.

"We are two souls dwelling in one body,

When thou seest me, thou seest him, And when thou seest him, thou seesi us both."

"Nakhurad az 4badat an bikhirad

(De Stane).

Ki ba haqq niku bud, ba khalq bad,

Sukhan manad az 'aqilan yadgar

Za Sa'di hamin yak sukhan yad dar,

Gunahgar-i-andishnak az khuda

Bih az parsa'e 'ibadat-numa."

Bostan of SA'di.

" That man void of understanding ate no fruit of his devotion,

Who, being good towards God, was evil towards his fellow-creatures.

The words of the wise endure for a memorial; remember thou this one saying of Sa'di :

'Better is the sinner who feareth God, than the saint who practiseth outward obedience." "

(Asiatic JourNaL).

" Nakunad jaur pisha sultani

Ki na ayad za gurg chaupani

Padshahi ki tarah-i-zulm fagand

Pae diwar-i-mulk-i-khwish bikanad."

GULISTA", chap. r.

14 
" Kingcraft yokes not with tyranny, The wolf cannot the shepherd be, Tyrants who on their people fall, Sap their own state's foundation wall." EAstwick.

" Nalaiq masjidam wa na khurad-i-kanisht

Izad danad gil-i-mara az chi sarisht Chun kafir-i-darwisham wa chun qahba'e zisht Na din wa na dunya wa na ummid-i-bihisht."

Omar Khayyam.

"From mosque an outcast and to church a foe, Out of what clay did Allah form me so?

Like sceptic monk or ugly courtesan, No hopes have I above, no joys below."

(WHINFIELD).

"Namanad sitamgar-i-bad ruzgar Bamanad baru l'anat-i-paedar."

"Not always will the wicked tyrant live The curse upon him will for aye survive." (EASTwick).

" Na mard ast an ba nazdik-i-khiradmand

Ki ba pil-i-diman paikar juyad;

Bale mard an kas ast az rue tahqiq

Ki chun khashm ayadash, batil naguyad."

Gulistan, chap. I.

"They that with raging elephants make war, Are not so, deem the wise, the truly brave, But in real verity the valiant are

Those who when angered are not passion's slave."

"Nashat jawani za piran ma jui

Ki ab-i-rawan baz na ayad dar jui."

Eastwick.

" Seek not the joy of youth from old men,

For the running stream returns not to the rivulet."

" Nang-i-bang u khamr bar khud mi-nihi

Ta dami az khwishtan tu va-rihi."

Clarke.

Bostan of S'Adi, chap. 9.

" Thou takest on thyself the shaine of hemp and wine,

In order that thou mayest for one moment escape from thyself."

" Nasazae-ra chu bini ba ikhtiyar

(E. G. BROWNE).

Aqilan taslim kardand ikhtyar ;

Chun na dari nakhun-i-darranda tiz

Ba dadan an bih ki kam giri sitiz."

Gulistan, chap. $x$.

"Seest thou that fortune crowns the unworthy,-then

Choose thou submission too with wiser men;

Hast thou not sharp and rending claws, then yield,

- For so 'tis best-to beasts the battle-field." (EAsTwick). 
“Nashayad banl Adam-j-khak zad

Ki dar sar kunad kibr-i-tundi wa bad

Tura ba chunin garmi wa sar kashi

Na pindaram az khaki-az atishi."

Gulistan, chap. 8.

" It suits not Adam's children earthly born,

To inclulge in pride, ferocity and scorn,

When I behold in thee such heat and ire,

I cannot think thee sprung from earth but fire."

"Nasihat hama "alam chu bad dar qafs ast

(Eastwick).

Ba pish mardam "ashiq chu ab dar ghirbal."

" 'Tis but to cage the wind advice to give;

To lovers 'tis but water in a sieve." Easrwick.

“ Nasir-1-khusraw bi-dashti mi-guzasht

Mast-l-la-ya'kil, na chun mey-khwaragan,

Mabrazi did u mazari ru-bi-ru

Bang bar zad; guft, 'k'ey nazzaragan!

Ni'mat-i-dunya, va ni'mat-khur bin;

Insh ni'mat! Insh ni'mat khwaragan." NASIR-I-KHUSRAw.

"Dead drunk (not like a common sot) one day

Nasir-i-khusraw went to take the air, I Iard by a dung-heap he espied a grave

And straightway cried ' $O$ ye who stand and stare,

Behold the world! Behold its luxuries!

Its dainties here-the fools who ate them, there !"

"Na talkh ast sabare ki bar yad-i-ust

(E. G. BROWNE).

Ki talkhi shakar bashad az dast-i-dust

Asirash na khwahad rihai za band

Shikarash na juyad khulas az kamand." . BOSTAN of S'ADI, chap. 3*

"Patience, which is in remembrance of II im is not bitter,

For bitterness from a friend's hand is sugar,

His captive desires not release from bonds,

His prey seeks not freedom from the snare."

(Clarke).

" Naubat-i-piri chu zanad kus-i-dard

Dil shawad az khush-dili wa "aish sard."

ANWAR-1-SUHEILI.

" When the changing watch of age strikes the drum of deep distress,

The heart grows cold to joyous things, to mirth and happiness."

" Nayasayad masham az tabla 'ud

EAstwick.

Bar atish nih ki chun 'ambar babuyad,

Buzurgi bayadat. bakhshindagi kun,

Ki dana, ta nayafshani, naruyad."

GUListan, chap. I. 
"The aloes-tray from which no fragrance came, If placed on fire, its insdoruus state

Will change more sweet than ambergris. So fame Thou for thyself by generous deeds create;

The unsown seed will never germinate." (EASTivick).

"Nawak mard afkan sad tir zan

An na kunad k'ah yake pir zan."

ANWAR-I-SUHEILI

" A hundred archers' slaughtering shafts do less

Than one crone's sigh, one sigh of helplessness."

EASTIVICK.

“ Nazara'e jamal-i-khuda juz khuda na kard."

Diwan-i-Shams-I-TABriz.

"None but God hath contemplated the beauty of God."

(NICHOLSON).

"Nazr kardan badarwishan buzurgi ra biyafzayad

Suleiman ba hama hashmat nazarha bud ba murash."

Anwar-I-Suheil.t.

"To condescend to holy men adds greatness to the great, King Solomon would not o'erlook an insect's low estate."

EAstwick.

"Nik ar kuni, ba jae tu niki kunand baz

War bad kuni, ba jae tu az badtar kunand, Imruz hasti az bad wa az nik bi-khabar, Roze buwad ki az bad wa nikat khabar kunand."

ANWAR-I-SUHEILI.

"If thou doest good, to thee, too, good they'll do, If ill, they will repay thee, and worse too, Art thou of good and ill now ignorant, There comes a day that they'll supply this want."

EASTWICK.

" Nik bashi wa badat guyad khalq Bih ki bad bashi wa nikat binand."

Gulistan

" Be thou but good and ill report despise, 'Tis better thus than thou should'st be Bad while thou seemest good in other's eyes."

"Nik daryab wa bad ma kun, zinhar,

Eastwick. Ki bad wa nik baz khwahi did Mail niki agar kuni hama ja Khwish ra Earfaraz khwahi did War tariq badi rawi, khud ra Paemal niyaz khwahi did." 
" Seek to do good, shun evil and take heed, For as thou actest, so too shalt thou speed, Ever in good dost thou incline to tread, Thou shalt then aye behold upraised thy head; But if in vice thou walkest, thou shalt see Thyself down-trampled by adversity."

Eastwick.

" Nik sahalast zinda bi jan kard

Kushtara baz zinda natawan kard;

Shart-1-aqiast sabr-i-tirandaz

Ii chun raft az kaman, na ayad baz."

Gulistan, chap. 8.

" 'Tis very easy one alive to slay,

Not so to give back life thou lak'st away;

Reason demands that archers patience show

For shafts once shot return not to the bow." Eastwick.

"Nik wa bad, chun hame babayad murd,

Khunak an kas ki gue niki burd."

Gulistan, Preface.

"Soon both good and bad must die,

Happy is the man who carries off the ball of virtue."

"Nist bar lauh-i-dilam juz Alif-i-qamat-i-dust

Chi kunam; harf-i-digar yad na dad ustadam." HAFIZ ODE, 416.

"My loved one's Alif. form stamps all my thought

Save that, what letter has my master taught?" BickNell.

\section{"Nist kasbe az tawakkul khubtar}

Chist az tafwiz-i-khud mahbubtar?

Gar tura sabr budi, rizq amadi,

Khwish ra chun ashigan bar tu."

ANWAR-I-SUHEH.I.

"The best of all professions is to lean

On providence. Can aught be livelier seen

Than faith. Were thou but patient, what thy fate must be

II ill come and cling all lover-like to thee."

EASTWICK.

" Nist khud az murgh parran in "ajab

K'u na binad dam wa uftad dar 'atab,

In ajab ki dam binad ba watad

Gar bikhwahad war nakhwahad mi fatad."

JALALUDDIN RUMI.

"The strange thing is not that winged fowl

Fall into the deadly snare without seeing it,

But that they see the snare and the limed twig

And yet fall into it, whether they will or no."

WHINFIELD. 
"Nist shu, nist az khudi zirak Badtar az hastiat jinayat nist."

"Become nought, nought from self-hood, because There is no crime worse than thy being." (Nicholson).

" Nist wash bashad khiyal andar jahan

Tu jahani bar khiyali bin rawan;

Bar khiyali sulhshan wa jangshan

Bar khiyali namshan wa nangshan."

JALALUdDIN RUML.

"Mere fancy's pictures ever objects mar, Things non-existent often frenzy paints,

We see mankind deluded over feints; Their peace, their war not seldom for a sham, Their pride, their shame some sorry epigram."

RedHouse.

"Ni arzad 'asl jan-i-man, zakhm nish Qina'at nikutar bidusab-i-khwish."

Bostan of S'ADi, chap. $\epsilon$.

" Oh, my soul! honey is not worth the sting's wound, Contentment with one's own syrup of dates is best."

(CLARKE).

" Niayad binazdik dana pasand

Shuban khufta wa gurg dar guspand." Bostan of SA'DI, chap. I.

"In the opinion of the wise it is not approved,

The shepherd asleep, and the wolf among the sheep."

(Clarkf).

"Niayad nikukari az bad ragan

Muhal ast duzandagi az sagan

Hama failsufan Yunan wa Rum

Nadanand kard angabin az zaqum."

Bostan of S'ADI, chap. 5 .

"A gond deed comes not from those of bad stock, As needle-work is impossible to dogs, All the philosophers of Greece and Rum

Know not how to make honey from the thorny tree."

(CLARKE).

“ Nigah dar fursat ki 'alam damist

Dame pish-i-dana bih az alamist

Biraftand war har kas dirud an chl kisht

Namand bajuz nam niku wa zisht."

Bostan of $\mathrm{S}^{\mathrm{A}} \mathrm{ADI}$, chap. 9.

"Take care of opportunity ; ? $\mathrm{r}$ the world is but for a moment, In the opinion of the wise a moment of life is better than 2 world ; They departed, and every one reaped what he sowed, There only remains good and bad name."

(Clarke). 
" Nihad shakh pur mowa sar bar zamin

Tawaz'a kunad hushmand guzin."

Pandnama of S'adi.

"The bough, full of fruit, placeth its head upon the earth;

The truly wise man practises humility." GlaDwiN.

"Nihal-1-dushmani bar kun, ki ranj-1-bi shumar arad."

HAFiz Ode, 220.

"Uproot thou hatred's plant completely, or woes unnumbered thenc may shoot."

(BICKNELL).

“ Nim nane gar khurad mard-1-khuda

Bazal-i-darwishan kunad nim-i-digar

Haft iqlim ar bigirad padshah

Hamchunan dar band iqlime digar."

Guz.1STA:, chap. r.

"The man of God with half his loaf content

To dervishes the remnant will present,

But though a king seven regions should subdue,

He'll still another conquest keep in view." (EAsTwick).

"Nishan bar takhta'e hasti na bud az Adam wa 'alam

Ki jan dar maktab-i-ishq az tamanna'e tu mi-zad dam." S'AID.

" No sign of man or world appeared on the tablet of existence,

When the soul breathed forth pursuant to thy will in the school of love."

“ Nishan-i-jawani za piran ma jui

(SHEN).

Ki ab-i-rawan bar ni-ayad bajui

Babayad hawas kardan az sar badar

Ki daur-i-hawas bazi amad ba sar,

Chu bar sar nishinad za piri ghubar

Digar 'aish-i-safl tawaqqu' madar."

ANWAR+I.SUHEILI.

"Seek not the signs of youth in aged men,

For to their source streams ne'èr return again ;

Age must all passion from its thoughts remore,

Since with old age expires the reign of love;

When age lets fall its snow-dust on the head,

Know that all hope of unmixed joy has fled." Eastwick.

" Nishasta bar lab-i-khandaq na didi yak kur

Baja'e luqma wa pul ar khuda'e justandi." Drwax-r.Shans-1-Tabriz.

"Thou hadst not seen a single blind man seated on the noat-edge, Had they sought God instead of morsel and pittance."

"Nizd-i-khirad shahi wa paighumbari Chun du nagin andar yak angushtare."

(NicholsoN).

ANWAR-1-SUHEILl.

"In reason's code the prophet and the king, Are but two jewels in the self-same ring." EAsTwick. 
"Nukhust admi sirate pish kun

Pas angah malak khue andisha kun;

Tu bar karra'e tausini bar kamar,

Nigar ta na plchad za hukm-i-tu sar."

Bostan of S'ADI, chap. 6.

"Practise first the human temperament, Think after that of the angelic temperament;

Thou art on the flanks of a refractory colt,

Take care that it twist not its head from thy order."

(Clarke).

“ Nunkiru in sha'na 'ala 'nnasi qaulahum wa la yunkiruna 'lqaula hina naqulu,

Idha sayyidun minna khala, qama sayyidun qawulun lima qala, 'lkiraimu fa'ulu,

Wa ma ukhmidat narun lana duna tariqin wa dhamanna fl'nnazilina nazilu."

ABD-AL-MALIK.

"We say nay whenso we will to the words of other men,

But no man to us says nay when we give sentence.

When their passes a lord of our line, in his stead there rises straight,

A lord to say the say and do the deeds of the noble,

Our beacon is never quenched to the wanderer of the night,

Nor has ever a guest blamed us where men meet together."

"Nuqsaha aina-i-wasf kamal

C. J. Lyall.

Wa in hiqarat aina 'az wa jalal;

Za anki ziddra zidd kunad paida yaqin,

Za anki ba sirka padid ast angabin :

Har ki nuqs-i-khwishra did wa shinakht

Andar istikmal-i-khud du aspa takht."

Jat.aludin Rum.

"Defects are the mirrors of the attributes of beauty

The base is the mirror of the High and Glorious One,

Because one contrary shows forth its contrary

As honey's sweetness is shown by vinegar's sourness,

Who recognises and confesses his own defects

Is hastening in the way that leads to perfection."

"Nuqs-i-mísaq wa 'ahud az ahmaqi ast Hifz-i-saugand wa wafa kar-i-taqi ast."

(WHINFIELD).

Anwar-I-SuheIll.

"Unfaithful dealing is an idiot's act,

The pious keep their oaths and guard their pact."

EASTwick.

"Nur-i-giti afruz chashma'e hur

Zisht bashad ba chashm-i-mushk-1-kur."

Gulistan, chap. 4 .

"The feeble-visioned mole perchance may scorn

The sun's bright fount that doth the world adorn."

EASTwick. 
" Nur-1-khurshaid 'am uftada bar shuma

Lekin az khurshaid na gashta juda."

Jalal.uddin Ru'si.

"I am the sunlight falling from ahove, let never severed from the sun I love."

" Nur-1-Tu ham muttasil ba hama wa ham judast."

Diwan-1-Shans-1.Taliriz.

"Thy light is at once joined with all things and apart from all."

Nicholsos.

"Nusalli malamati 'rrijali biriyyatin wa nafri shurura 'yamu b'llahwi w'allibi

Idha ma tazakhat sa'atun fa 'ja'al annaha lakhairin fa'inna 'ddahra 'asalu dhu shaghbi

Fa'in yaku khairun au yakun b'adhu rahatin fa'innaka laqin min ghumum wa min karbi."

Iyas ibn Al Akatt.

"Let us wash from our hearts sour speech of wislom with cups abrim, And cut short the ills of life with laughter and jest and joy!

Yea, when once a moment comes of rest from the whirl, be quick

And grasp it ; for Time's tooth bites, and quits not, and mischief waits, And sure, if a bright hour lifts thy soul to a little peace,

Enough in thy path there lies of shadow and grief and pain."

" Padshahi dar chaman gul ra z'anki gul

C. J. Lyal.L.

Bawujud nazuki az khar bistar mi-kunad."

Angar-I-SuHeill.

"Thus by the rose the garden's crown is worn Because, though soft, it couches on a thorn."

"Padshah pasban-i-darwishast

EASTWICK.

Garchi n'imat bifarr-i-daulat-i-ust

Gusfand az barae chaupan nist

Baiki chaupan barae khidmat-i-ust."

Gulistax, chap. $x$.

"Kings are but guardians who the poor should keep, Though this world's goods wait on their diadem,

Not for the shepherd's welfare are the sheep

The shepherd rather is for pastuing them." (EAsTwick).

" Pae miskin piyada chand rawad

K'az tahammul sutuh shud bukhti

Ta shawad jism-i-farbihi laghar

Laghari murda bashad az sakhti."

Guintan, chap. 2.

"What distance can the tired footman go

When Bactria's camel faints beneath the load?

In the same time that fat men meagre grow,

The lean will perish on afliction's road." (EAstwick). 
"Paikan az jarahat badar ayad wa azar dar dil bamanad."

Gulistan, chap. 3 .

" The shaft may have been extracted from the wound, but the pang still remains in the heart."

"Paimana ast in jan, paimana in chi danad K'az pak mipazirad dar khak mirasanad Dar ishq biqararash paimudanast karash Az 'arsh misitanad bar farsh miflshanad," Drwan-1-Shans-I.Tabriz.

"This soul is a measure; how should the measure know

That it is receiving of spirit and conveying to dust?

Its task is to measure in restless love,

Taking from heaven above, scattering o'er earth below."

"Paiwasta za bahr-i-shawat-i-nafsani

(Nicholson).

In jan-i-sharifra hami-ranjani,

Agah na'i ki afat-i-jan tu and,

Anha ki tu dar arzu-i-ishani."

Omar Khayyan.

"You who in carnal lusts your time employ,

Wearing your precious spirit with annoy,

Know that these things you set your heart upon,

Sooner or later must the soul destroy." WHINFiELD.

" Pak az 'adam amadim, napak shudim,

Asuda dar amadim, wa ghamnak shudim,

Budim az ab-i-dida dar atish-i-dil

Dadim ba bad umr wa dar khak shudim."

Omar Khayyam.

" Death finds us soiled though we were pure at birth, With grief we go, although we came with mirth, Watered with tears and burned with fires of woe, And, casting life to winds, we rest in earth." (Wirnfield).

"Pandam agar bishnawi ai padshah

Dar hama daftar bih az in pand nist,

Juz ba khiradmand mafarma 'amal

Garchi "amal kar-i-khiradmand nist."

Gulistax, chap. 8.

"King ! let my words with thee find grace,

My book than this can nought more sage advise:

The wise alone in office place,

Though office truly little suits the wise." (EASTIVICK).

"Para'e atish bud an pur gazand

Ki ba dame shu'ala bararad buland

Admi atish khurad az hadd fazun

K'az dam-i-u dud niayad birun."

ANWAR-I-SUHEILI. 
"A piece of fire that furious man will be

Whose breath the flame of rage upkindles high, His fiery wrath exceeds all just degree, Who ne'er gives vent to a remorseful sign." EAsTwick.

" Par-1-taus dar auraq-1-musahif didam

Guftam 'in manzilat az qadr-i-tu me binam bish'

Guft 'khamush; ki har kas ki jamall darad

Har kuja pae nihad, dast nadarandash bish.'"

"One day amid the Quran's leaves a peacock's feather neeting, I said 'This place exceeds thy worth; thou dost it not become,

'Peace!' it replied, 'for to each one who wears the charm of beauty, Go where he will, him all receive with favour as a duty."

(EAstwick).

"Partau haqq ast wa an m'ashuq nist

Khaliq ast an guya, makhluq nist."

JALALlidin RUM.

"Woman is a ray of God, not a mere mistress, The Creator's self as it were, not a mere creature !"

(WIINFIELD).

“ Partau-i-nikan nagirad har ki bunyadash badast

Tarbiyat na-ahira chun girdgan bar gumbadast

Nasl-i-fasad-inan munqat'a kardan aulatar ast

Wa bikh-i-tabar-ishan bar aurdan ain-i-maslahat

Kl atish nishandan wa akhgar guzashtan

Wa afai kushtan wa bacha nigahdashtan kar khiradmandan nist."

Gulistan, chap. $\mathrm{I}$.

"The good in vain their rays will pour,

On those whose hearts are bad at core,

To instruct the base will fail at last

As walnuts on a dome you cast.

It is better to cut off their race and trilse and more advisable to extirpate them root and branch, since, to extinguish a fire and to leave the embers, and to kill a serpent and preserve its young are not the acts of wise men."

(EASTWICK).

"Partau zatash zada bar ma" wa tin

Ta shuda dana paziranda zamin ;

Khak amin wa har chi dar wai kashti

Bi khanat jins-i-an bardashti."

JALALUdDiN RuMi.

"What rays of wisdom poured on water and on land

Ere earth could nourish seed, yield corn to our demand !

The earth a faithful trustee gives back what we sow,

No fraud, embezzlement in its trust do we know."

(REDHOUSE). 
" Pas ey mard, puyanda bar rah-1-rast Tura nist minnat khudawand ra'st. Takabbur makun bar rah-i-rasti Ki dastat giriftand wa barkhasti." S'adi, Bostan, chap. 8.

"Then, $\mathrm{O}$ man, running on the straight path, Thanks are not for thee, they are for God, Display not pride on the path of truth; For they (the angels) seized thy hand and thou didst rise."

“Pasandid ash bakhshaish wa lekin

(Clarke). Manih bi rish-i-khalq azar marham; Nadanist anki rahmat kard bar mar Ki an zulmast bar farzand-i-Adam."

Gulistan, chap. 8.

"Pity is commendable-that we own,

- Yet on the tyrant's wound no ointment place, He that has mercy to a serpent shown, Has acted cruelly to Adam's race."

(EASTWICK).

"Pas az burdan wa gird kardan chu mur Bikhur pish az an k'at khurad kirm-i-gur."

Bostan of S'ADI, chap. 2.

"After carrying and collecting like the ant, Enjoy,-Defore that the grave-worm devours thee."

“Pas kuja nalad, kuja zarad laim

(Clarke). Gar tu na paziri juz nik, ey karim, Rau, makun zishti, ki nikha'e ma Zisht ayad pish an ziba'e ma."

JaLALLUdin RUMi.

"Where should the ignoble lament and pray, If Thou didst only accept the good, $\mathrm{O}$ merciful One? Go, do not commit sin, for even our good deeds Appear as sin in the sight of our Beloved."

"Pas ba surat 'alam-i-asghar tu'i Pas ba ma'na 'alam-i-akbar tu'i Zahiran an shakh asl-i-mewa ast Batinan bahri samar shud shakh hast." JaLALludin Rumi.

"In outward form thou art the microcosm . But in reality the macrocosm, Seemingly the bough is the cause of the fruit, But really the bough exists because of the fruit."

" Pasha chu pur shud, bazanad pilra

WHINFIELD. Ba hama tundi wa salabat ki ust Murchaganra chu buwad ittifaq Shir-i-zhiyanra bidaranand pust." 
" Gnats will an elephant o'ercome if they Unite against their foe, so huge and grim ; And ants collected in one dense array, Though fierce the lion be, will vanquish him."

(EASTWICK).

" Pas mahal wahi gardad gush-i-jan

Wahi chu buad, guftane az hiss nihan, Gush-i-jan wa chashm-i-jan juz in hissast, Gush-i-aql wa gush-i-hiss za in muflis ast. Lufz jabaram 4shqra bi sabr kard, Har ki 'ashiq nist habs jabr kard, In m'aiyat ba haqq ast wa jabr nist In tajalli-e-mahast, in abr nist."

JALALUdDIN RUMt.

"The mind's ear becomes the sensorium of inspiration, For what is this Divine voice but the inward voice? The spirit's eye and ear possess this sense, The eye and ear of reason and sense lack it. The word 'compulsion' makes me impatient for love's sake, 'Tis he who loves not, who is fettered by compulsion, This is close conmunion with God, not compulsion, The shining of the sun, and not a dark cloud." (WhiNfield).

"Pas za jan jan chu hamil gasht jan Az chunin jani shawad hamil jahan, Pas jahan zayad jahana digare In hashar ura numayad mahshare."

JaLALUdDIN RUML.

"As soul became pregnant by the Soul of souls, So by the former soul did the world become pregnant; Then the world brought forth another world, And of this last are brought forth other worlds."

(WHINFIELD).

"Payapa biyafshan az aina gard

Ki saiqal na girad, chu zangar khurad." Bosran of S'Adr, chap. 8.

"Shake off continually dust from the mirror of the heart, For it takes not polish, when the blight eats it." (ClarkE).

“ Pish az man wa tu lail wa nahare budast, Gardanda falak za bahr-i-kari budast, Zinhar qadam ba khak ahista nihi K'an mardumak-i-chashm-i-nigare budast."

Omar Khayyam.

"Days changed to nights ere you were born or I, And on its business ever rolled the sky, See you tread gently on this dust, perchance 'Twas once the apple of a beauty's eye." (WHiNfIELD). 
" Pish-i-tu az nur muwaflqtar and Wa za past az saya munaflqtar and Garm wa lek az jigar afsardatar Zinda wale az dil khud murdatar."

AnWar-1.Suheill.

" Before thee they are kindlier than light, And yet behind than shadows falser far; Warm,-but in inward feeling frigid quite, Quick,-but at heart they dead and lifeless are."

EASTwICK.

" Pish kesri za khiradmand hakiman miraft

Sukhan az s'abtarin mauj dar in lahja'e gham

An yake guft ki bimari wa anduh daraz

Wa an digar guft ki nadari wa piri ast baham

Siyume guft ki qurb-i-ajal wa siwa 'amal

Aqibat raft bi tarjih siyum hukm hukm." Jami, Biharistan, (2).

" Intelligent philosophers queried near Kesra, About the heaviest wave in this abyss of grief, The first said it must be sickness and long pain, The second averred it is the union of old age and poverty ;

The third said, it is the nearness of death without good deeds, And to him the palm of viciory was awarded."

REHATSEK.

“ Pish Yusuf nazish wa khubi ma kun

Juz niyaz wa ah yaqubi ma kun

Ta dam-i-Isa tura zinda kunad

Hamchu khwishat khub wa farkhanda kunad

Dar baharan kai shawad sar-sabz sang

Khak shu ta gul baruyad rang rang."

JALALUDDIN RUM.

" In presence of Joseph * no coquetries use

But humble thyself; soft entreaties infuse ;

From Jesus a breath then may blow upon thee,

Transform thee to what he was, what thou mayest be :

A stone will not blossom because it is spring,

As earth make thyself ; flowers around thee may cling."

REDHOUSE.

“ Pish z'ishan ma hama yaksan budim

Kas nadanisti ki ma nik wa bad'im

Bud naqd wa qalb dar 'alam rawan

Chun jahan shab bud wa ma chu shirwan

Ta bar amad aftab ambiya

Guft 'Ey ghash, dur shu, safl biya!'

Chashm danad farq kardan rangra

Chashm danad l'alra wa sangra."

JALALUDDIN RUM.

* The Eastern ideal of beauty. 
"Before they (the prophets) camc, we were all alike,

No one knew whether he was right or wrong, Genuine coin and base coin were current alike, The world was a night and we travellers in the dark, Till the sun of the prophets arose and cried 'Begrone, O slumber ! welcome, O pure light !' Now the eye sees how to distinguish colours, It sees the difference between rubies and pebbles."

WHINFIELI).

"Pidar ra "asal-i-bisyar ast Wa lekin pisar garmi dar ast."

Guzistan, chap. 3.

" Of honey hath the Sire a plenteous store, But the son's feverish and must not have more."

EASTWICK.

"Pidr chun daur-i-umarash munqazi gasht

Mara in yak wasiyyat kard wa bugzasht,

Ki shahwat atishast az wai bi parhiz

Bikhud bar atish-i-duzakh makun tiz

Dar an atish na dari tagat-i-suz

Ba sabr abi bar in atish zan imruz."

Gưlistan, chap. 8.

"When my sire's age had reached its latest day, He gave me this advice and passed away:

'Lust is a fire ; from it thyself keep well;

Nor kindle 'gainst thyself the flames of hell,

Thou hast not patience to endure that flame, I trow ;

W'ith patience, as with water, quench it now." EAstrwick.

Pil wa gurg wa haidar wa ashkar niz

Azhdaha'e zuft wa mur wa mar niz

Balki khak wa ab wa bad wa ham sharar;

Maya z'u yaband ham di, ham nahar;

Har damash laba kunad in asman

Ki faru nagzaram, ey haqq, yak zaman,

Astan-i-man asmat wa hifz tu ast

Jumla muttawiya yamin an du dast."

Jalaltudin Remi.

"All elephants, wolves and lions of the forest, All dragons and snakes and even little ants, Yea, even air, water, earih and fire,

Draw their sustenance from Him both winter and summer,

Every moment the Heaven cries to Him, saying

'O Lord, quit not Thy hold of me for a moment :

The pillar of my being is Thy aid and protection." "

WIINFIELD. 
"Pindar, ey dar khazan kishta jau, Ki gandam sitanl ba waqt-i-dirau? Masal inchunin guft amuzgar Makun bad ki bad bini az ruzgar; Kase nik binad bar har du sarai Ki niki risanad ba khalq-i-khuda'i."

ANWAR-1-StheIL1.

"Thou who didst barley in the autumn sow, Expect not wheat in harvest-time to mow ; This maxim by the sage was uttered, 'Do No ill lest thou from time ill-treatment rue; He in both worlds a good reward will find Who lives - a benefactor to mankind." " EAstwick.

"Pindasht sitamgar ki sitam bar ma kard

Bar gardan-i-u bamand wa bar ma biguzasht." Gulistan, chap. I.

"Dream'st thou tyrant thou hast wreaked on me thy rage and scorn? The burthen from my neck has passed, on thine must ever stay."

(EASTIVICK).

"Pirana saram ishq-i-jawani bar sar uftad

Wa an raz kl dar dil binihuftam badar uftad

Az rah-i-nazar murgh-i-dilam gasht hawagir,

Ey dida, nigah kun, ki badam-i-kih dar uftad."

HAFIZ.

" Elderly of head, into my head youthful love hath fallen,

And that mystery of love that in the heart I concealed out hath fallen, From vision's path the bird of my heart went soaring,

O eye of my heart, behold into whose snare it hath fallen."

"Pirana saram 'ishq-i-tu dar dam kashid

(CIARKE).

Warna za kuja dast-i-man wa jam nabid

An tauba ki aql dad janan bishikast

Wa an jama ki sabr dukht ayyam darid."

OMAK KHAYYAM.

" Ah! thou hast snared this head though white as snow,

Which oft has vowed the wine-cup to forego,

And wrecked the mansion long resolve did build,

And rent the vesture penitence did sew."

WHINFIELD.

"Pire za kharabat birun amad wa mast

Sujjada badush wa kasa'e bada badast,

Guftam 'Sheikha, tura chi hal amad pish,'

Gufta 'Mai khur, ki kar-i-alam bad ast.'"

Omar Khavyam.

"A sage I saw to tavern-house repair,

Bearing a wine cup and a mat for prayer;

I said, 'O Shaikh! what does this conduct mean?'

He said, "Go drink! the world is nought but air."

WHINFIELD. 
"PIr-i-gham "ishqam ar chi tiflam Tifl rah-i-ishqam ar chi piram Chun kard zamana'e sitamgar Dur az tu ba band-1-gham astram An bih ki zi sabr rukh natanam Bashad ki murad-i-dil biyabam."

HAFIZ.

"I am old in the sufferings of love, although but an infant; an infant in the paths of love, yet old in years; seeing that during your absence tyrannic fortune holds me in the fetters of sorrow. It is best not to turn away my face from patience ; perhaps I may yet obtain my heart's desire."

“ Pir-i-ma har chi kunad ain-i-wilayat bashad FORBES.

Banda'e pir-í-mughanam ki zl jahlam birahand

Zahid wa "ujub wa namaz wa man wa mastl wa niyaz

Ta tura khud zi miyan ba ki 'inayat bashad."

HAFIZ.

"Whatever our Pir (saint) doeth the essence of friendly assistance is,

Together are the ascetic and haughtiness and prayer; and I and intoxication and supplication,

Let us see with whom of these two Thy favour indeed is." CLARKE.

"Pir zane mue sujah karda bud

Guftamash, 'Al mamak-i-dirina ruz

Mue ba talbis sujah karda gir,

Rast na khwahad shudan in pusht-i-kuz.'" Gu'lssas, chap. 6.

"An aged dame had dyed her locks of grey,

'Granted' I said, 'Thy hair with silver blent

May cheat us now ; yet littlc mother! say

Can'st thou make straight thy back which time hath bent?"

" Pisarera pidre wasiyyat kard

(EASTWICK).

K'ai jawanmard, yad gir in pand :

Har ki ba ahl-i-khud wafa nakunad,

Nashawad dust rue wa daulatmand."

Gulistan, chap. 7 .

"This counsel to his son a father gave,

'Dear youth ! to recollect these words be thine,

Who for their kinsmen no affection have,

On them the star of fortune ne'er will shine." Eastwick.

"Pisar k'u miyan-i-kalandar nishast

Pidar gu za khairash faru shawi dast;

Darighash ma khur bar halak wa talaf

Ki pish az pidar murda bih na khalaf."

Bostan of S'ADI.

"The boy who sat among Kalandars (monks),

To his father say: 'Wash thy hands of his welfare!'

Suffer not regret as to his destruction and ruin,

For the degenerate son dead before his father is best."

Clarke. 
“ Piyaz amad an bi hunar jumla pust

Ki pindasht chun pista maghze dar ust

$\mathrm{Az}$ in nau ta'at niayad bakar

Biru, uzr-i-taqsir-i-ta'at biar."

Bostan of SA'Dl.

"That worthless man is but an omon, all coating, who thinks that like the pistachio nut he possesses a kernel.

Obedience of this sort availeth nothing; go rather and entreat forgiveness for thy defective obedience."

(ASIATIC JOURNAL).

"Pushida zir-i-zaban ast mard." Bostan of S'Adi, chap. 7 .

$$
\text { "A man is hidden under his own tongue." (CLARKE). }
$$

"Pust che buwad? guftha'e rang, rang,

Chun zara bar ab kash na buwad dirang

In sukhan chun pust wa ma'na maghz dan

In sukhan chun nafs wa ma'na ham chu jan

Pust bashad maghz badra aib push

Maghz niku ra za ghairat ghaib push."

JaLALUDdin RUM.

"When words deceitful are employed as wraps for gutle, They're bubbles on the water, only last awhile,

Such words are merely shell; the intent their kernel is,

Or coloured portraiture of man; no life is his,

A shell may often cover kernel of foul smell,

A kernel sound can well afford to lose its shell." REDHOUSE.

\section{" Pukhtim andishha salha k'az daur-i-sipihr}

Kar-i-ma akhir chunin ya anchunan khwahad shudan

Ya bar in manwal ganj wa sim wa zar khwahim yaft

Ya dar an iqlim-i-ma rawan khwahad shudan

'Aqibat ma'lum shud k'inha khiyale bish nist

Har chi khwahad Hakim-i-mutlaq haman khwahad shudan."

ANWAR-1-Suheill.

" Long years we schemed that in time's onward course,

Or thus or thus should be the issue. Then

Our rule in such a region should have force,

Or gold or silver treasures meet our ken,

At length we learned that this was idle thought,

God's will alone is to existence brought."

EASTWICK.

"Pulad parha'im ahan rubast ishqat

Asl-i-hama talab tu, dar khud talab na didam."

DIWAN-I-SHAMS-I-TABRIz.

"We are pieces of steel, and Thy love is the magnet,

Thou art the source of all inspiration, in myself $I$ have seen none."

(NICHOLSON). 
"Pumba'e wiswas birun kun za gush

Ta ba gushat ayad az gardun kharush

Ta kuni fahm an mu 'ammahash ra

Ta kuni idrak ramz fash ra."

JAl.AlUDDIN RUMi.

"Take the cotton of evil suggestions from the mind's ear,

That the heavenly voice from above may enter it,

That you may understand that riddle of IIis,

That you may be cugnisant of that open secret." Winsillis.

“ Pur khun za firaqat jigare nist ki nist,

Shida-e-tu sahibnazare nist ki nist

Ba anki nadari sar-j-sauda- - -kas

Sauda-e-tu dar hich sare nist kl nist."

Omar KhaYyam.

" No heart is there but bleeds when torn from Thee,

No sight so clear but craves Thy face to see,

And though perchance Thou carest not for them,

No soul is there but pines with care for Thee."

(WHINFIELD).

"Pur kun zi bada jam damadam bi gush-i-hush

Bishnau az u hikayat-i-Jamshid wa Kaikubad

Haflz, garat zi pand-i-hakiman malalatast

Kutah kunam qissa, ki umarat daraz bad."

HAFIZ.

"Fill up thy bowl with wine, and then to reason's ear let come, The legend which its flood suggests of Kaikubad and Jam, If counsel, Ilafiz, from the wise to thee seem dry and drear, At once I'll make my story short,-right long thy life be here!"

BICKNELL.

“Pur mi-nashawad kasa'e sarha za hawas

Har kasa ki sar-nigun buwad pur na shawad." AKHLAQ-1-Jalail.

" What stream could fill the skull with what it craves, That tilted ewer where nought abides that enters?"'

THOM'SON.

" Pursidam az tabibe ahwal-i-dust, gufta

'Fi qurbiha azabun, fl b'udiha 'ssalama'

- Bad-1-saba zi maham nagah niqab bardasht

Ka' shshamsi fi 'dhdhuha tatlu 'u mina 'lghamama." Hafiz.

"I asked how fared she; the physician spake

'Afar trom her is health, but near her ache,'

The east wind from my moon removed her veil,

At morn shone forth the sun from vapours pale."

BICKNELL. 
“ Pursi tam'a-ra 'K'at pidar kist?' Bi guyad 'Shub 'dar iqdar Hlahi' Wagar gui ki 'Karat chist?' guyad 'Bi mihnatha'e hirman umr kahi."

Jami, Beharistax, chap. I.

"If thou askest covetousness 'Who is thy father?"

It says 'Doubt in the divine powers,' And if thou askest 'What is thy business?' it replies

"To grieve over the disappointments of life." (REHATseK).

"Puzband wiswasa ishq ast wa bas

Warna kai wiswasra bastast kas?

Ashiqe shu, shahid khubi bi ju

Saiad murghabi hamekun ju ba ju

Kai bari z'an ab abatra burd?

Kai kuni z'an fahm ki fahmat khurd?

Ghair in ma'qulaha, ma'qulaha

Yabi andar 'ishq ba far wa baha

Ghair in aql-i-tu Haqq ra aqlahast

Ki badan tadbir asbab shumast."

Jalaludin Rumi.

" Love is a perfect muzzle of evil suggestions ;

Without love who ever succeeded in stopping them?

Be a lover and seek that fair beauty,

Hunt for that waterfowl in every stream !

How can you get water from that which cuts it off,

How gain understanding from what destroys understanding,

Apart from principles of reason are other principles

Of light and great price to be gained by love of God,

Besides this reason of yours God has other reasons

Which will procure for you heavenly nourishment."

(IVHinfield).

"Qabil-i-amr dini qail shawi

Wasl jui bad az an wasil shawi

S'ai shukr-i-ni'amat qudrat buwad

Jabr tawangar an niamat buwad."

JALALUdDiN Rumi.

"Accept His command and you will be able to execute it, Seek union with $\mathrm{Him}$ and you will find yourselves united.

Exertion is giving thanks for God's blessings,

Think ye that your fatalism gives such thanks?" WHINFIELD.

“Qabra Ma'anin 'anta 'awwalu hufratin mina 'lardhi khuttat li 'ssamahati madhja'a

Wa ya qabra Ma'anin kaifa waraita judahu wa qad kana minhu 'lbarru wa 'lbahru mutra'a

Bala qad was'ita 'ljuda, wa 'ljudu mayyitun wa lau kana hayyan dhiqta hatta tasadda'a

Fatan 'aisha fl m'arufihi b'ada mautihi kama kana b'ada 'ssaili majrahu marta'a." 
" Within that cell, within that heap, Friendship and truth and honour sleep, Beneficence that used to clasp The world within her ample grasp There rests entombed, of thought bereft For were one conscious atom left, 'Twould yearn new blessings to display, Burst from the grave andl seek the day. But though in dust thy relics lie, Thy virtues, Mano ne'er shall die, Though Nile's full stream be seen no more That spread his waves from shore to shore, Still in the verdure of the plain His vivifying smiles remain."

J. D. Carlyle.

"Qad aflaha 'l'muminuna 'lladhina hum fl salatihim khashi'un w'alladhina hum 'ani 'l llaghwi mu'ridhun wa 'lladhina hum li 'zzati failun wa 'lladhina hum lifuru jihim hafldhun." Korax, chap. 23.

"Now are the true believers happy; who humble themselves in their prayer, and who eschew all vain discourse, and who are doers of alms. deeds, and who keep themselves from any women except their wives."

"Qadam bayad andar tariqat, na dam,

ki asli na darad dam bi qadam."

Bostan OF S'ADI, chap. I.

"In religion the foot of action is necessary, not the breath of words Because, breath without action has no real essence." (CLARKE).

“ Qad dabba habbuka ff 'lashya ajm tha

Ma fl'l wujudi siwa man shaqqahu 'shshahnu." AKHLAQ.1-Jalall.

"Through all this busy world Thy love doth creep,

Yes, nothing is but this sweet pain doth rend it."

THOMPSON.

"Qaddim alkhuruj qabl alwuluj."

Gulistan Preface.

"Try the egress before you enter." EAstwick.

"Qadr-1-aflyat kase danad ki ba musibat giriftar ayad."

Gulistan, chap. $\mathrm{x}$.

"A person who is overtaken by calamity learns to value a state of freedom from ill."

(EASTIICK).

“Qad raj'ana min jihadl 'l'asghar im

Ya nabi andar jihad-i-akbar im

Quwat az Haqq khaham wa tauflq-1-lap

Ta ba suzan bar kunam kuh-i-Qaf."

JALALCDDIN KLMS. 
" We've done with outer warfare, lesser as it is, And as the Prophet, wage the greater warfare, his ; We put our trust in God, from Hin we ask for aid, With His assistance faith can move a mountain staid."

ReDhousE.

" Qadri majmu'a gul murgh-i-sahar danad wa bas

Ki nar har ku waraqi khwanad ma'na danist

Ey ki az daftar-i-aql ayat-i-'ishq amuzi,

Tarsam in nuqta batahqiq nadanl danist."

HAFiz Ode, 66.

" None but the bird interprets well the volume of the rose,

Not every reader of a leaf its latent import knows,

Oh thou who fain in reason's book the text of love would see,

True knowledge of this subtlety is not I fear for thee."

BickNell.

" Qad yaslamu 'lmutmasu min hufratin

Wa yaqa'u fiha 'lbasiru 'nnaziru

Wa yaslamu 'ljahilu min lafzatin

Wa yahlaku flha 'lalimu 'Imahiru

Wa yaisaru 'Imuminu fi rizqihi

Wa yurzaqu 'lkafiru w'alfajiru."

Alif Laila wa Laila.

" The blind hath 'scaped a gaping pit

In which the broad-eyed seer hath stumbled,

The dolt hath 'scaped a quirk of wit

By which the skilful sage was humbled;

The faithful pine for daily bread,

The heathen and the sot is fed."

TORRENS.

"Qadru 'rrajuli 'ala qadri himmatihi."

Arabic Proverb.

"The dignity of a man depends on the height of his aspiration."

"Qafya andisham wa dildar-i-man

Guyadam m'andish juz didar-i-man

Khush nishin ey qafya andish-i-man

Qafya daulat tu'i dar pish-i-man

Harf chi bud ta tu andishi az an?

Harf chi bud, khar diwar razan

Harf wa sut guftra barham zanam

Ta ki bi in hirsa ba tu dam zanam."

JaLALuddin Rumi.

" Of rhymes do I dream? 'Tis my love orders me

Of love still to dream ; swain devoted to be,

'Thyself make thou happy. Rhymes leave now alone

The rhyme I seek thou art. I love thee my own.

What's rhyme that thou turnest thy thoughts thitherward,

Mere bramble on wall, hedging round our vineyard,

I care not for words, for asseverations,

My time if I pass in these sweet delusions."

ReDHOUSE. 
"Qala Abuqratu rahima-hu 'llahu 'l'umru qasirun wa 'Bsina'atu tawilatun w'al waqtu dhaiylqun wa 'ttajribatu khatirun wa 'lqaza'u "asirun."

" Hippocrates, may God have compassion on him, said, "Life is short, art is long, time is narrow, experience dangerous, judgment difficult."

"Qalam batalkhi shirini, ey pisar, raftast

Agar tursh nishini, qaza chl gham darad."

ANWAR-1-SUHEILt.

"Bitter and sweet the Pen has traced, my son,

What does fate reck, though thou look sourly on ?"

"Qalb miguyad za nakhwat har damam

Eastwick.

'Ey zar khalis man az tu kai kamam ;'

Zar hamaguyad 'Bale, ey khwaja tash,

Lek mlayad mahakk, amada bash !"'

JALAI.UDDIN RUMI.

"The base coin says to me with pride every moment,

'O pure gold, how am I inferior to you?'

The gold replies, 'Even so, O comrade;

But the touchstone is at hand ; be ready to meet it !"

(WHINFIELD).

"Qalbu 'Imumini baitu 'llabi."

Saying of MUhamaiad.

"The heart of the believer is the house of God."

“Qalbu 'l'mumini baina 'ssaba'ini min 'asabi 'rrahman yaqlubuhu haitha yasha'u."

Saying of Muhamiad.

"The heart of the believer is between two fingers of the Merciful. He turneth it whithersoever IIe pleases."

"Qalla mani 'stahadafa linnadhali fa khalasa mina 'ddai l'udhal, au astathara naq'a "limtihani falam yuqdha b'ulimtihani."

Maqamat of Hariri.

" Rare is he who exposes himself to the conflict and then escapes the mortal hurt, or who stirs up the dust of trial and then catches not the note of contempt."

(CHENERY).

“Qamarist ru namuda, pur-i-nur bar kushuda, Dil wa chashm wam bistan za kase agar na darl."

Diwan-I-Shams-i-Tabriz.

"The moon has revealed her face, and opened her radiant wings, Borrow a soul and eyes from some one, if you have them not."

(Nicholson).

" Qarar bar kaf-i-azadagan na girad mal

Na sabr dar dil-1-'aghiq na ab dar ghirbal." Gulistan, chap. I. 
"Money abides not in the palm of those who careless live, Nor patience in the lover's heart, nor water in the sieve."

(EASTIVICK).

- Q'ar chi bi-gurizad har k'u aqilast Z'anki dar khilwat safahae dilast Zulmat chi bih ki zulmathae khalq Mi-gurizad aqil az ghaugha'e khalq."

ANWAR-I-SUHEILI.

"Why do the wise to the lone cavern fly?

'Tis that, alone, they find tranquillity.

Since darkness better is than man's dark deeds,

The wise man from the bustling mart recedes."

“" Qarz ast f'ilha'e badat pish ruzgar

(EASTWICK).

Dar har kudam daur ki khwahad ada kunad."

Dabistan.

"Thy evil deeds are a debt ever in the presence of fortune, Which must be repaid in whatever age she makes the demand."

"Qat'a suhbat kardan az yaran suri khushtar ast

SHEA.

K'az huzur namuwaflq bi-huzuri bihtar ast;

Hamdame k'az suhbatash khurram na gardad khatirat

Az chunin hamdam ba sad farsang duri khushtar ast."

ANWAR-I-SUHEILI.

"From fellowship of seeming friends 'twere better far to part, Absence is better than with one thou lovest not to stay, A comrade whose suciety delighteth not thy heart,

'Twere best from him a hundred leagues to be removed away."

EASTWICK.

"Qatilu fi sabili 'llahi w'alamu anna 'llaha sami'un 'alim."

KORAN, chap. 2.

"Fight in the cause of God and know that God is He who knoweth, heareth."

(RODWELL).

“Qatra bagrist ki 'az bahr judayim hama'

Bahr bar qatra bakhandid ki 'mayim hama,'

Dar haqiqat digare nist khudayim hama

Lek az gardish-i-yak nuqta judayim hama."

Omar Khayyam.

"The drop wept for his severance from the sea,

But the sea smiled for 'I am all' said he;

Yea God is all in all, there's none heside

But one point circling seems diversity."

(WhiNField).

"Qatra'e dil ra yake gauhar fatad K'an gardunha wa daryaha nadad."

Jalaluddin Rumi.

"God drops into the heart a single pearl-drop

Which is not bestowed on oceans or skies." WHINFIELD. 
"Qaulun m'arufun wa maghflratun khairun min sadaqatin yatba'uha 'adhan wa 'llahu ghaniyun halim."

KURAN, chap. 2.

"A kind speech and forgiveness is better than alms followed by injury. And God is Rich, Clement."

RONWELL.

"Qaume mutafakkarand dar mazhab wa din

Jam'ao mutahaiyyarand dar shakk wa yaqin,

Nagah manadi bar ayad za kamin

K'ey bikhabaran rah na an ast wa na in."

Omar Khayyam.

"Some look for truth in creeds and forms and rules,

Some grope for doubts or dogmas in the schools ;

But from behind the veil a voice proclaims,

"Your road lies neither here or there, O fools!'"

WHINFIEL.D.

“Qaume za guzaf dar gharur uftadand

Wa andar talab-1-hur wa qusur uftadand,

Ma'lum shawad chu pardaha bardarand

K'az kue tu dur wa dur wa dur uftadand."

Omar Khayyam.

"Some, filled with overweening fantasy,

Houris in Paradise expect to see ;

But, when the veil is lifted, they will find

How far they are from Thee, how far from Thee."

WHINFIELL.

“Qaza daste ast panj angusht darad

Chu khwahad az kase kame bararad,

Du bar chashmash nihad, digar du bar gush

Yake bar lab nihad, guyad ki "khamush!"'

Kasim al, ANWar.

"Fate is a hand that exercises its five fingers on its victim. Two are placed on the eyes, two upon the ears, and onc upon the lips, saying, "Be for ever silent."

(OUSELEY).

"Qaza digar na shawad war hazar nala wa ah

Bashukr ya bashikayat ayad az dihane;

Firishta ki wakil ast bar khazain-i-bad

Chi gham khurad ki bimirad chiragh-1-bewa zane."

Gulistan, chap. 8.

"Fate is not altered" by a thousand sighs,

Coinplain or render thanks, - arrive it will :

The angel at whose bidding winds arise

Cares little for the widow's lamp, if still

It burns, or by the storm extinguished dies."

(EASTWICK).

" Qazi ar ba ma nishinad bar flshanad dast ra

Muhtahsib gar mai khurad, ma'zur darad mastra."

Gulistan, chap. 2. 
" E'en the Qazi * would applaud us, could he of our party be, Thou Muhtahsib † quaff the wine-cup and thou wilt the drunkard free." (EASTWICK).

"Qifa nabki min zikra habibin wa manzili Bi-siqti 'l-liwa baina' ddakhuli wa haumali Fatudhiha fa'l maqrati lam ya'fu rasmuha Lima nasa jatha min junubin wa shamali."

AMr-UL-KaIs.

"Stay! let us weep at the remembrance of our beloved, at the sight of the station where her tent was raised by the edge of yon bending sands between Dahul and Haumel,

Tudah and Mikra; a station the marks of which are not wholly effaced, though the south wind and the north have woven the twisted sand."

SIR W. JONES.

"Qifl 'lqadhiyyatin flhi hatta tajtali

Wasfayihi fl hala radhahu wa batshihi

Wa yabina khullabu barqihi min sidqihi

Li shshaimin wa wabluhu min tashshihi

Fahunaka in tara ma yashinu fawarihi

Karaman wa'in tara ma yazinu fa' fshihi."

Maqamat of Hariri, chap. 22.

"Stay thy judgment on him until thou hast had a view of his two characters in his two conditions of content and anger;

And until his deceiving flash be distinguished from his truthful one by those who watch it, and his flood from his light rain,

And then if thou perceive what dishonours him, hide it generously, but if thou see what becomes him, publish it." Chenery.

"Qila fl ma ghabara mina 'zzamani, inda 'limtihani yukramu 'rrajulu 'au yuhanu."

MAQAMAT OF HARIRI, chap. 2.

"It was said aforetime that by trial is a man honoured or contemned."

Chenery.

“Qil'adare k'az kinar-i-mamlukat,

Dur az sultan wa saya sultanat;

Pas darad qil'a ra az dushmanan,

Qil'a nafarushad bamal bigiran;

Ghaib az shah dar kinar saghraha,

Hamchu hazir $u$, nigahdarad wafa.

Nizd-i-Shah bihtar buwad az digaran,

Ki bakhidmat hazirand wa janfishan;

Ta'at wa iman kunun mahmud shud,

B'ad marg andar 'ayan mardud shud."

JALALUdDIN RUMı.

* Judge. † †olice Inspector. 
"The warden of a castle on the marches laid,

Far from his sovereign, distant from much-needed aid,

Defends his post with valour from beleagucring foe,

Dislains to be bought over, scorns the tempter's moe,

His station's on a frontier, no eye sees him act

To duty true, he honestly fultils his pact.

Then in his monarch's presence honours due he gains,

Above the brave men fighting in the royal trains,

Man's faith and piety on earth are prized of God,

But after death professed, less value have than clod."

(REDHOUSE).

“Qila l'Iflatuna 'ma huwa 'shshaiu 'lladhi la yahsunu an yuqala wa in kana haqqan' qala madhu 'linsani nafsahu." AL Iвsнаiн.

"Plato was asked "What is that thing the utterance of which is unpleasing though it be true." He replied, "Self-praise."

"Qimat-i-durr giranmaya chi danand awamm

Hafiza, gauhar-i-yakdana madih juz ba khawas."

HAFIZ.

"The value of the precious pearl what know the people?

O Hafiz, give not the precious pearl save to the noble."

Clarke.

"Qina'at kun, ai nafs, bar andake,

Ki sultan wa darwish bini eke

Chara pish khusrau bikhwahish rawi

Chu yak su nihadi tam ‘a, khusrau’i.”

BostAN of $\mathrm{S}^{\prime}$ Adr, chap. 6.

"Oh soul! be content with a little,

That thou may'st consider the sultan and dervish as one ;

Why goest thou before the king with entreaty,

When thou placest avarice aside, thou art a king." (CLARKE).

"Qina'at tawangar kunad mard ra

Khabar kun haris jahangard ra ;

Khudara na danist wa ta'at na kard,

Ki bar bakht wa ruzi qina'at na kard."

ANIFAR-1-SUHEIL.

" Contentment makes man wealthy. Tell it then To the unsatisfied and world-wandering men; . They ne'er knew God, nor paid Him worship due, Since with their lot they no contentment knew."

EAsTwick.

"Qismat za raft za azal karda and

Chand pai rizq paragandagi?

Faida'e zindagiat bandagist

Sar makash az qaida'e bandagi." Jani, BeHARIStax, chap. x. 
" Thy share has been allotted to thee from all eternity, How long wilt thou distress thyself for a livelihood? The object of thy existence is service, Turn not thy head away from the laws of service."

" Qissatu 'l'ishqi la infisama laha

REHATSEK. Fusimat hahuna lisanu maqal."

HaFiz.

"He who has loved relates an endless tale, Here the most eloquent of tongue must fail."

BickNell.

"Qiyamat kase bini andar bihisht

Ki m'ana talab kard wa dawa bihisht

Ba mana tawan kard dawa durust

Dam-i-bi qudam takiyagah ast sust."

Bostan of $\mathrm{S}^{\prime}$ adr.

"At the Resurrection thou seest in Paradise that one

Who sought truth and let go pretension;

By truth one can make a proper claim,

Breath without action is a slothful resting-place."

"Qiyamat ki nikan ba 'ala rasand

(Clarke).

Za q'ar-i-thara bar thurayya rasand;

Dar an ruz k'az f'il pursand wa qaul

Ulu 'l'azm ra tan bilarzad za haul.

Ba jae ki dahshat khurdand ambiya

Tu 'uzr-i-gunah ra chi dari biya?"

Böstan of $\mathrm{S}^{\mathrm{t}} \mathrm{ADr}$, chap. 9 .

" On the Resurrection Day when the good attain to the highest dignity, They rise from the bottom of the grave-ashes to the Pleiades, On that day when they ask of deeds and words,

The bodies of the lords of resolution (the prophets) will tremble from fear,

In the place where the prophets suffer fear,

Come-what excuse for sin hast thou?"

Clarke.

“ Qiyamat ruz-i-'arz-i-akbar ast

Arz an khwahad ki ba zeb zafar ast;

Har ki chun Hindu bad wa sauda'st

Ruz arzash naubat ruswai ast

Barg yak gul chun na darad khar-1-u

Shud baharan dushman-i-asrar-i-u."

JALALUDDIN RUMr.

" The day of judgment is the day of the great review,

Whoso is fair and enlightened longs for that review;

Whoso like a Hindoo is black with sin,

The day of review will sound the knell of his disgrace,

If his thorn puts not forth a single rose-bud

The spring in disclosing him is his foe."

WHINFIELD. 
- Qiyas az halat-1-insani ma-kun

Manzil andar Jaur wa dar ihsan ma-kun Jaur wa thsan, ranj wa shad, hadis ast

Hadisan mirand wa haqq shan waris ast."

JALALUUdiN RUMI

"Argue not from the condition of common men,

Stumble not at severity and mercy;

For mercy and severity, joy and sorrow are transient

And transient things die; God is heir of all." Whinfield.

"Qufl nih bar khalq wa pinhan kun kalid."

Jalaluddis Rum.

" Place a padlock on your throat and hide the key."

"Qul ara'altum in ahlakani 'llahu wa man ma'i au rahimana faman yujiru 'lkafirina min adhabin alim."

Koran, chap.

"Say: What think ye? Whether God destroy me or not and those who follow me, or whether He have mercy on us, yet who will protect the unbelievers from a woeful torment?"

RODWELL.

“Qul, eyyu shai'an akbaru shahadatan qull 'llahu shahldun baini wa bainakum wa uhia llayya hadha 'lquranu li undhirukum blh1 wa man balagha 'a'innakum litashaduna 'anna ma'a 'llahl alihatan ukhra qul la ashhadu qul innama huwa illahun wahidun, wa "nnant bariyun mimma tushrikun."

KORAN, chap. 6 .

"Say: 'What thing is the strongest in bearing testimony?' Say '(rod, $\mathrm{He}$ is witness between me and you, and this Koran was revealed unto $\mathrm{me}$ that I should adnonish you therehy and also those unto whom it shall reach. Do you really profess that there are other gods together with God.' Say 'I do not profess this.' Say 'Verily lle is one God and I am guiltless of what ye associate with Him.", .

"Qul 'inni la 'amliku lakum dharran wa la rashadan, qul'inni lan yujlrani mina 'llahi ahadun wa lan 'ajida min dunihi multahidan."

Koran, chap. 72.

" Say: 'No power bave I for your hurt or benefit.' Say 'Verily none can protect me against God, neither shall I find any refuge beside Him."

RODWEL..

"Qul lilladhl basurufl 'ddhari ayyarana

Hal 'anada 'ddharu illa man lahu khataru

Ama tara 'rriha in habbat 'awasifuha

Falaitha t'asifu llla ma huwa shshajaru

Wa ma tara 'lbahra t'alu fauqahu jlyafun

Wa tastaqirru ba qasa q'arihi dduraru."

Alif Laila wa Laila 
" Go ask of him who jeers us when fortune does her worst, Whom doth fortune most oppose, but him she favours first?

See'st not the sweeping tempest sweep gustily along,

Vet roughly blow about that bough that stately is and strong, See'st not the refluent ocean bear carrion on its tide, While pearls beneath its wavy flow fixed in the deep abide?"

TORRENS.

"Qul liman qad shakahu zumbuhu

Halakta ya miskinu au tantaqish

F'akhlisi 'ttaubata tatmis biha

Mina 'lkhataya 'ssaudi ma qad nuqish

Wa haka k'asa 'nnushi fa'shrab wajud

Bi 'fadhlati 'lk'asi 'ala man 'atish." Maqamat of HariRI, chap. 49.

"Say to him whom the thorn of his sin stings, "Pluck out the thorn, poor brother, else thou art lost,

Wipe out with sincere repentance any writ that black misdeeds have left on thy book of deeds,

This cup of counsel drink of it, and bestow on one athirst that which remains in the cup."

STEINGass.

"Qul liman yahmilu hamman

Inna hamma la yudumu

Mithlu ma tafna 'Imasarata

Hakadha tafna 'Ihumumu."

Alif Laila wa Laila.

"Go say to him borne down by woe That not for aye will grief endure; For like as joy its end must know, E'en so the end will sorrow cure."

TORRENS.

"Qul, man yarzuqukum mina 'ssama'i w'al 'ardhi 'amman yamliku 'ssama' wa 'l'absara wa man yukhriju 'lhayya mina 'Imayyiti wa yukhriju 'Imayyita mina 'Ihayyi wa man yudabbiru 'l'amra fasayaquluna 'llahu faqul 'afala tattaqun." Koran, chap. ro.

"Say, "Who provideth you food from heaven and earth? or who hath the absolute power over the hearing and the sight? and who bringeth forth the living from the dead, and bringeth forth the dead from the living, and who go verneth all things?' They will surely answer 'God.' Say, 'Will ye not therefore fear Him ?" "

"Qulubu 'lahrari qabur 'alasrari."

Arabic Proverb.

"The hearts of the nolle are the graves of secrets."

"Qulu liman nawama 'layyamu lahu ramat,

Kum aq'adat na'ibatu 'ddhari kam qamat;

In kunta nimta fa'ainu 'llahi ma namat

Liman safa 'Iwaqtu wa 'ddunya liman damat."

Alif Laila wa Laita. 
"Say ye to him that lies inert, the days of time

Shoot forth their arrows on thee. Oh! how many

I Iath fortune set upright, how many hath she

Cast down. Though thou be sleeping, dull and heedless,

Surely the eye of God is ever wakeful.

To whom hath time hrought peace of mind? who is there

The world hath e'er stood fast with?"

TORRENS.

"Quran ba sar-i-zaban ast wa zar darmiyan-i-jan."

Gulistan, chap. 6.

"The Quran is on the tip of his tongue, and the gold is in the centre of his heart."

(EASTWICK).

"Quranu hudda 'll 'nnasi wa bayyanatin mina 'l'huda wa 'Ifurqani."

KORAN, chap. 2.

"The Koran a direction unto men and declarations of direction, and the distinction between good and evil."

(SALE).

" Quran ki bahin kalam khwanand ura

Ki gah na bar dawam khwanand ura

Dar khatt pujala ayate rushan hast,

K'andar hama ja mudam khwanand ura." OMar Kh.AYYaM.

"Men say the Quran holds all heavenly lore,

But on its pages seldom care to pour,

The lucid lines engraven on the bowl,

That is the text they dwell on evermore."

(WHINFIELD).

"Qurb-1-awazash gawahi mi-dihad

K'in dam nazdik az yare jihad

Lazzat-i-awaz khwishawand niz

Shud gawah bar sidq an yar aziz

Pish zirak k'andarunash nurba'st

Ain in awaz mana bud rast."

JaLALLiddin Rumi.

"The nearness of the voice proves to such an one

That the voice proceeds from a friend who is near,

The sweetness of the kinsman's voice too, $O$ beloved,

Proves the veracity of that kinsman,

To the wise whose hearts are enlightened

The mere sound of that voice proves its truth."

WHINFIELD.

"Qurb ruhani agar hast miyan-i-man wa dust

Chi tafawut kunad agar b'ud makane bashad?" ANiwar-I-Suheili.

"Am I united with my friend in heart, What matters if our place be wide apart?" EASTwick. 
"Qurratu 'l'aini man an mewa'e dil yadash bad

Ki khud asan bishud wa kar-i-mara mushkil kard

Sarban, bar-i-man uftad, khuda ra madadi

Ki ummid-i-karamam hamrah-i-in mahmil kard

Ah, wa faryad ki az chashm-i-hasud-i-mah-i-charkh

Dar lahd mah-i-kaman abru'e man manzil kard."

HAFIZ.

" My eyes' bright light, my heart's sweet fruit was he ; be unforgot

That he who passed so lightly hence made burdensome my lot.

Driver ! my camel-pack has fallen! Give help for God's dear sake, I looked for kindness when I chose this litter's course to take, Alas! that from the high sphere's moon which envious glanced below, The sepulchre contains my moun whose eyebrows were a bow."

"Qut imani dar in zindan kam ast,

BICKNELI.

Wa an chi hast az qasd in sag dar khamast;

Az namaz wa saum wa sad bicharagi

Qut zauq ayad bar way yak bargi ;

Astaiiz Allah min Shaitanihi

Qad halakna ah I min taghianihi."

Jalaluddin Rumi.

"In this prison the food of true faith is scarce,

And by the tricks of this dog what there is, is lost,

In spite of prayers and fasts and endless pains

Our food is altogether devoured by him,

Let us seek refuge with Allah from Satan,

Alas! we are perishing from his insolence." (WHINFIELD).

"Quwat-i-dana hama az khun-i-jigar mi-binam

Ablahanra hama sharbat zi gulabast wa shakar

Asp-i-tazi shuda majruh ba zir-i-palan

Tauq-i-zarrin hama dar gardan-i-khar mi-binam

Pand-i-Hafiz bishnau, khwaja birau, niki kun

Ki man in pand bih az ganj-i-gauhar mi-binam."

HAFIZ.

" Nought save his own heart's blood the food of the wise-I see

Sherbets of sugar and rose the world to the fool supplies,

Galled by the pack-saddle's weight the Arab's proud steed grows old,

Yet always the ass's neck encircled with gold I stee,

Master, go forth and do good! The counsel of Hafiz prize,

For better than treasured pearl this counsel so wise I see."

“ Ra'aitu. 'Imanaya khabta 'ashwa man tusib

BickNell.

Tumithu wa man tukhti yu'ammar fayahrami

Wa man haba 'asbaba 'Imanaya, yanalnahu

Wa'in yarqa 'asbaba 'ssama'i bissulami." Mu'AlLAKAH OF ZUHAir.

" I have seen the Dooms tranıple men as a blind beast at random treads, Whom they smote he died; whom they missed, he lived to strengthless eld, Who trembles before the Dooms, yea him they shall surely seize, Albeit he set in his dread a ladder to climb the sky." C. J. Lyall. 
"Rabbina 'afrigh 'aleina sabran wa thabbit 'aqdamana."

KORA.s, chap. 2.

" O our I.ord, pour upon us ste.rdfastness and set our feet firm."

“ Raftam sue khatira wa bagristam ba zar

RODWELL.

Az hijar dustan ki asir fana shudand;

Ishan kuja shudand, chu guftam, khatira ham

Dad az sada jawab ki "ishan kuja shudand?"

AMir KhUsRv.

"I went to the cemetery and wept bitterly for the absence of friends, now the captives of non-existence. 'Where are they?' said I, in sadness, 'those dear friends of my heart?' When a voice from the graves sofily repeated "Where are they ?'"

(OUSE.I.EY).

" Raftam u burdam dagh-i-tu dar dil

Wadi bi-wadi, manzil bi manzil."

"I journed on bearing the brand of thy grief in my heart, From valley to valley, from stage to stage." (E. G. BRow.vi).

" Raftand wa za raftagan yaki na amad baz

Ta ba tu biguyad sukhan az parda-e-raz

Kairat za niyaz mikushayad na namaz

Bazicha buad namaz bi sidq wa niyaz."

Omar KhaYYaM.

"They pass away and none is seen returning,

To teach that other world's recondite learning,

'Twill not be shown for dull mechanic prayers,

For prayer is nought without true heartfelt yearning."

" Rahae mukhtalif asan shud ast

(WHINFIELD).

Har yaki ra millate chun jan shud ast;

Gar muyassar kardan haqq rah budi

Har Jahud wa Gabar az u agah budi."

Jal.ALUdDIN KUMr.

"Ah, how many diverse roads are pointed out And each followed by some sect for dear life, If the right road were easily obtainable

Every Jew and Gueber would have hit on it."

"Rah-i-nik mardan azada gir

Chu istada'i dast-i-uftada gir."

(WHINFIELD).

Anwar-I.Suhello.

"No barrier to the good man's path oppose, And, if thou standest, raise thy fallen foes."

" Rahm bar Isa kun wa bar khar ma kun

EAstwick.

Taba'ra bar aql-i-khud sarwar ma kun

An khar-1-Isa mizaj-1-dil girift

Dar maqam-i-aqilan manzil girift

Gar za Isa gashta'i ranjur dil

Ham az u sihhat rasad, ura ma hil."

Jalaluddin Rumi. 
"Pity keep for Jesus, pity not the ass,"

Let not fleshly impulse intellect surpass;

If an ass could somewhat catch of Jesus' mind,

Ranked among the sages he his place would find,

Though because of Jesus you may walk in woe,

Still from Him comes healing; never let Him go."

"Ra'iz ki tausin ra kunad ram

Kunad ahistagi ba kara kham

Ba tundi tausin az sar tund gardad

Wa gar kundi numa'i kund gardad."

AnWAR-I-SUHEILI.

"Each horse-tamer who would vanquish the unbroken fiery steed,

Must the young colt first with kindness and with gentle measures lead, Fury will but stir the courser to more headlong heat; and so

From the rider's want of spirit steeds will dull and sluggish grow."

(EASTWICK).

"Rakhte ki dashtim bayaghma baburd "ishq

Az sud wa az ziyan wa za bazar farighim."

Diwan+I-ShaMs.I-TABRIZ,

"Love carried off as plunder the chattels which we possessed,

We are independent of profit and loss and market."

(NICHOLSON).

"Rang-i-tazwir pish-í-ma na buwad

Shir-i-surkham wa afa'i siyaham."

HAFIZ ODE, 4I8.

"The colour of deceit I wholly lack,

I am a lion red or serpent black."

BICKNELL.

" Ranj wa ghamra haqq pai an afrid Ta badin zidd khushdili ayad padid, Pas nihaniha bazidd paida shawad Chunki haqqra nist zidd pinhan buwad;

Nur-i-haqqra nist ziddi dar wujud

Ta ba zidd-i-ura tawan paida namud,

La jurm 'absarana la tudrikuhu,'

Wa 'hu yudrik' bin tu az Musa wa kuh."

JALALUDDiN RUmi.

"God created pain and grief for this purpose,

To wit, to $\mathrm{n}$ anifest happiness by its opposites.

Hidden thingi are manifested by their opposites,

But as God ha.i no opposite, He remains hidden,

God's light has no opposite in the range of creation

Whereby it may be manifested to view,

Perforce 'Our eyes see Him not, though He sees us,'

Behold this in the case of Moses and Mount Sinai."'

(WHINFIELD).

* i.e., the body. 


\section{ARABIC AND PERSIAN:SAYINGS}

" Raq'a dukhtan blh wa ilzam-i-kunj-i-sabr

K'az bahr-i-jama raq'a ba khwajagan nawisht

Haqqan ki ba 'uqubat-i-duzakh barabar ast

Raftan bapae marde hamsaya dar bihisht."

Gulistan, chap. 3.

"Better to suffer and sew patch overipatch

Than begging letters to the rich to write, Truly it doth hell's torments fairly match

To mount by others in celestial light."

(EAstwick).

"Rasad az kaman-i-pinhan shab wa ruz tir-1-parran

Blspar jan-1-shirin, chi kuni, sipar na dari."

Diwan-1-Shams-1-Tabriz.

"Night and day comes a winged arrow from the hidden bow,

Yield up your sweet life; what can you do? you have no shield."

"Rasm buzurgan buwad insaf kar

NichOLSON.

Kar khasan nist bajuz kha wa khar."

ANWAR+I-SUHKILI.

"The great show equity in all they do

While base men torture and are tortured too."

EASTWICK.

"Rasti mujlb-i-razal khudast

Kas na didam ki gum shud az rah-i-rast." GuLISTAN, chap. x.

"God favours those who follow the right way,

From a straight road I ne'er saw mortal stray."

" Rasu malika wa hia 'rruhun qad salimat

La ta'asfan lishailin ba'daha zahaba."

(EASTWICK).

ZOHEIR.

"Thou hast thy life, thy chiefest treasure, still

Grieve not if aught beside be gone and past." (Palmer).

" Rawan gar farughe paziraft az $u$

Za khud raft wa bi hush manam guft az $u$

Za mihr u nawazish kunad banda ra

Ki bardashtan shayad afganda ra

Gadara tawangar kunad mihr-i-u

Jahan partau'e az khur chihra'e u

Mar u ra juz u kastniyarad situd

Ki u dar ni ayad ba guft wa shanud."

$J_{\text {AM } \cdot 1 \cdot K_{A I} K_{H U S R O}}$

"If the spirit receives illumination from $\mathrm{Him}$

It becomes beside itself and its speech is 'I am without intellect,'

Through love He confers bounties on His servants

As it is proper to raise up the fallen,

His love renders the mendicant a man of power,

The world is but a ray emanating from the sun of His face,

None but $\mathrm{He}$ can duly praise Himself

As He cannot become the object of speech or hearing." (SHEA). 
" Rau, ki tu'i shifta'e ruzgar Yak na kuni baz numai hazar."

NizaMI.

"Go, for thou art beguiled by fortune; thou performest not one deed, nevertheless thou displayest a thousand." Asiatic Misceldany.

"Rawan-i-khufta agar danadi ki dar khwabast Az an chi didi na khush shudi wa na ranjur."

Diwan-I-Shams-1.TABRIz.

" If the sleeping spirit knew itself to be asleep,

Whatever it might see, it would feel neither joy nor sorrow."

(NICHOLSON).

"Ra'yat chu bikh ast wa suitan darakht

Darakht ey pisar bashad az bikh sakht."

BostAN OF S'ADI.

"The people are the root and the king is the tree that grows from it; and the tree, O my son, derives its strength from the root."

SiR W. JONes.

" Raz ba dil guftam wa bisyar khun khurdam az u

Kashki danistame awwai ki hamdam yaftan nist."

Anwar-1-Suheill.

"I told the secret which my heart had nursed, Full sore it made me weep ;

Would that my simple heart had known at first None can a secret keep."

Eastwick.

“ Raz juz ba razdan ambaz nist

Raz andar gush-i-munkir raz nist."

JALALUDDin RUMi.

"Mysteries are not communicable save to those who know, Mystery in the ear of infidels is no mystery." Whinfield.

"Raz-i-khud ba yar-i-khud ta an ki bitawani ma gui Yar ra yare buwad, az yar-i-yar andisha kun."

Azızı

"As long as thou canst, communicate not thy secret to thy friend, For that friend has another ; beware therefore of thy friend's friend."

"Raz khudra chun tu khud mahram na'i Digare khud mahram-i-an chun buwad?"

(SHEA).

ANWAR-1-SUHEILI.

"To thine own secret thou art unfaithful, then Canst thou expect more faith in other men?" EASTwick.

" Raz makusha ba har kas ki dar in markaz-i-khak Sair kardim base, mahram israr na bud."

ANWAR-I-SUHEILI.

" Not to each one thy secrets tell, for earth's wide space upon, Much we have wandered, yet have found in whom to trust, not one."

EAstwick. 
"Rldha 'dhdhalill bl khaf dhi 'laishi maskanatun

Wa 'l'izzu 'inda rasimi 'lainuqi 'dhdhuiuli

Fa'dra blha fl nuhuri 'ibidi jaflatan

Muaridhatin mathani llujmi bi 'ijudubi."

Al Tughrai.

" Contempt and want the wretch await

Who slumbers in an abject state,

Midst rushing crowds, by toil and pain

The meed of honour we must gain,

At honour's call the camel hastes

Through trackless wilds and dreary wastes,

Till in the glorious race she find

The fleetest coursers left behind."

J. D. Carlyle.

" Riha kun sitam ra jak bargi

Ki kam 'umr amad sitamgaragi

Shahinshah chun rae ra bad kunad,

Yaqin dan ki bad dar haqq-i-khud kunad."

ANWAR-1-SUHEILI.

"Give up thy course of tyranny and wrong

At once, - for ne'er was life of tyrant long;

Know, when a king perverts his judgment, he

Does that which for himself too scathe will be."

EAstwick.

" Rinde didam nishasta bar khushk zamin

Na kufr wa na Islam wa na dunya wa na din,

Na haqq na haqigat na shari'at na yaqin

Andar du jahan kira buwad zahra'e in?"

OMAR KhaYyan.

"An outlaw in the desert did I see, He had no wealth, no faith, no heresy

No God, no truth, no law, no certitude,

In the two worlds where's man so bold as he?"

WHINFIELD.

" Rish janaha 'lhurri in hassahu

Zamanuhu la kana man lam yarish

Wa'njidi 'lmutura dhulman fa'in

"A jazta "an injadihi, fa'stajish."

maqanat of Hariri.

" Feather the free whose plumage fair time hath stripped,

May he not live, who, while he can, feathers not.

Ielp one oppressed by tyranny: if too weak to helf thyself, then summon up hosts for him." STEINGass.

" Rishta ra ba suzan amad irtibat

Nist darkhur ba jamal summu 'lkhayyat

Kai shawad barik hasta'e jamal

Juz blmiqraz riyazat wa "amal."

JALALUdDIN RUMt. 
"The thread and the needle are related to one another; but a camel is not fitted to pass through the eye of a needle; how should the body of a camel become slender except by abstinence and exertion?"

" Riyasat ba dast-i-kasane khata'st

Ki az dast-i-ishan dastha bar khuda'st

Neku-kar hargiz na binad badi

Chu bad parwari, khasam-i-jan khud'i."

ANWAR-I-SUHEILI.

" 'Tis wrong that he a nation should enthral

Against whose hand men lift their hands in prayer;

Evil will ne'er the virtuous man befall

But evil-doers their own lives ensnare." Eastwick.

"Rizq ayad pish har k'u rizq just

Ranj kushisha za bi-sabri t'ust ;

Jumia-ra Razzaq ruzi mi-dihad

Qismat har yak ba pishash mi-nihad."

ANWAR-I.SUHEILI.

"The allotted portion reaches every seeker. So

Our own impatience is our trouble's spring,

God's blessings freely to all creatures flow,

His hands to all the destined bounty bring." EAstwick.

" Rizq har chand bi guman birasad

Shart-i-aqlast justan az darha ;

Garchi kas bi ajal nakhwahad murd

Tu ma ru dar dihan-i-azhdaha."

Gul.istan, chap. 3.

" Though without doubt fate will our want supply,

Reason requires it be sought from home;

'Tis true that none will unpredestined die,

Yet in a dragon's maw one should not come." (EAstwick).

" Rizq maqsumest wa waqt-i-an muqarrar karda and

Bish az in wa pish az an hasil na mi-gardad ba jihad."

ANWAR-1-SuHEIL.1.

" Our daily food is destined, and the time too they allot, Aught more or aught hefore this, by our struggles we win not."

EAstwick.

"Rubba sadiqin lamani fl widadiha

Ulam yaraha yauman fa yudhahu iahu udhri." Gulistan, chap. 4.

"Oft have my friends reproached me for my love,

The day will come they'll see her and approve."

"Rubba yaumin bakaitu minhu falamma

EASTWICK. Sirtu fl ghairihi bakaitu alaihi."

MajANi AL ADAB.

"Often in old days I wept because of him, But when I came among strangers I wept to have him." 
"Ruda'e tang bl yak nan-1-tihi pur gardad

Nimat-1-rue zamin pur na kunad dida'e tang." Gulistan, chap. 8.

"A single lnaf the stomacli will supply, But not earth's richest gifts the greedy eye."

(EASTWICK).

" Rue agar chand piri chihra wa ziba bashad

Na tawan did dar aina ki nurani nist

Abid wa zahid wa Sufl hama atfal rahand

Mard agar hast ba juz "alim-1-rabban! nist."

ANWAR-I-SuHEILI.

"If darkness should the sullied mirror mask,

Vainly in it the fairest face may glance;

Recluse, monk, Sufi children are astray,

The man is he who walks in God's own way."

F.ASTIVICK.

"Rue bar khak-1-'ujz me guyam

Har sahrgah ki yad miayad

Ey ki hargiz faramusht nakunam

Hichat az banda yad miayad?"

Gulistan, chap. 2.

" Humbly in dust I bow each day

My face ; with wakening memory,

O Thou whom I forget not, say;

Dost Thou bethink Thee e'er of me?" (EAsTwick).

“ Rue khubat ayate az lutf bar ma kashf kard

Z'an sabab juz lutf wa khubi nist dar tafsir-i-ma." .

HAFiz.

"By its grace thy beautiful face explained to us a verse of the Koran, For that reason in our explanation is nought save grace and beauty.'

(ClAKKE).

"Rue maqsud ki shahan ba dua mi-talaband

Mazharash aing'e tal'ati darwish anast."

HAFIZ.

"The form of the object that the kings of the world seek,

Its reflection is the mirror of the appearance of dervishes."

"Rue tama" az khalq ba pich az mardi

Tasbih-i-hazar dana ba dast ma pich."

Clarke.

AnWAR-I-Suheili.

"Be manly, and from cringing cease, for this

Than thousand beaded rosaries better is." EAsrwick.

" Ruh chu az mihr kinarat girift

Ruh shawad pish-i-tu jumla nuqush."

Diwan-I-Shans-I-TABriz.

"When the spirit lovingly embraces Thee, In Thy presence all images become spirit."

(Nicilolson). 
" Ruhra ki ishq-i-haqiqi shi'ar nist

Nabuda bih ki budan-i-u ghair-‘ar nist." Diwan-I-Shams-I-Tabri7.

" 'Twere better that the spirit which wears $r_{1}$ ot true love as a garment Had not been ; its being is but shame."

(NICHOLSON).

" Ruhra suhbat-i-najins azabist 'alim."

HAFiz.

"The society of the uncongenial is excruciating torment to the soul."

Clarke.

" Ruh sakht latif ast wa ishq sakht ghaiyur

Chi jae surat agar khud namad shawad sad tu."

Diwan-I-Shams-I-TABriz.

" Spirit is very subtle and love is very jealous,

What room for form, if the felt is hundredfold?"

" Rukh-i-tu dar dilam amad, murad khwaham yaft

(Nicholson).

Chira ki hal-i-niku dar qafa'e fal nikust."

HAFIZ.

"Thy face came into my heart; my desire I shall gain

For after the happy omen is the happy state."

Clarke.

" Rushna'e tal'at-i-tu mah na darad

Pish-i-tu gul raunaq-i-giyah na darad

Gusha'e abru'e tust manzil-i-janam

Khushtar az in gusha padshah nadarad."

Hariz.

"The moon hath not the luminosity of thy face,

In comparison with thee the rose hath not the glory of grass.

The corner of thy eyebrow is my soul's dwelling,

A happier corner than this the king hath not."

"Rusta zadagan-i-danishmand

Bawaziri badshah raftand,

Pisaran-i-wazir naqis-i-aql

Bagada'i barusta raftand."

Gulistan, chap. 7 .

"The king his vazirstip bestows

On peasants' sons, wise, though of lowly birth ;

The vazir's dullard children in their stead

Through town and hamlet humbly beg their bread."

EAstwick.

" Rutab nawarad chub-i-khar zahra bar

Chi tukhm afgani bar haman chashm dar."

Bostan of S'Adi.

"The wood of the colocynth brings not the green date, Whatsoever seed thou didst cast, expect that very fruit." 
" Ru wa sar dar jamaha plchida id

La jurm ba dida wa nadida id. Admi didast wa baqi pust ast

Dida anast anki did dust ast."

JaLALUDDIN REMI.

"With muftled heads you cannot see,

You've wrapped your cloaks in folds alout your heads and eyes,

Your sense of sight cannot see what before you lies.

The world's eye man is; all the rest's mere skin and shell,

A real eye's he who atrives his friend to see right well."

REDHOUSE.

“ Ruwaydaka la tu'qib jamilaka b'il'adha

Fa tadhi wa shamlu 'Imali munsad'i

Wa la tataghadhdhib min tazziyudi sa'ilin

Fa ma huwa fl saughi 'llisani bimubtad 'i."

MaQAiat of HaRiRi, chap. 45.

" Eh, genuly, let not bounty be followerl by injury for else both thy wealth and fame alike will be lost and gone,

And fly not into a passion if a beggar exaggerates, for he is by no means first to polish and gloss his speech."

STEINGass.

" Ruza yaksu shud, wa id amad wa dilha barkhast

Bada nushi ki dar u rui wa riyai nabuwad

Bihtar az zuhdfarushi ki dar u rui riy'ast

Ma na rindan-i-riya'im wa harifan-i-nifaq

An ki u 'alim-i-sirrast bar in hal gawa'st

Farz-i-Izid biguzarem wa bakas bad nakunem

W'an chi guyand rawa nist naguyem rawa'st."

HAFIZ.

" [The fast has gone, and the feast has come, and hearts have risen.]

Better the drunkard void of fraud and wiles

Than virtue's braggart who by fraud beguiles,

I am no hypocrite, no toper sly,

Attest it He who secrets doth espy,

Let us obey God's laws and injure none

Nor teach as good what we are taught to shun." BickNell.

" Ruz bashad ki biayad basalamat bazam

Ey khush an ruz ki ayad bar salami bar ma."

HAFIZ.

"When my beloved will come in safety again may soon be the day,

O happy the day when the beloved cometh in safety to our house."

Clarke.

" Ruz dar kasb-i-hunar kush, ki mai khurdan-1-ruz

Dil chu aina dar zhang-i-zalam andazad,

An zaman waqt-i-mai subh-farugh ast, ki shab

Gird-1-khargah-i-ufuq parda'e sham andazad."

HAFIZ. 
" By day seek virtue; wine if quaffed by day The heart's pure mirror shall with dust o'erlay ; Indulge in cups of wine aurora-bright When the sky's tent is curtained by the night."

BiCKNEII.

" Ruze agar ghame rasadat, tangdil ma bash Rau, shukr kun, mabad ki az bad batar shawad, Ey dil sabur bash, wa makhur gham, ki 'aqibat In sham subh gardad, wa in shab sahar shawad, Haflz, chun nafa'e sar-i-zulfash ba dast-i-tu'st

Dam dar kash ; ar na bad-i-saba ra khabar shawad."

HAFIZ.

" If one day a great grief should reach thee, be not strait of heart, Go: offer thanks. God forbid that worse than bad should be, $O$ heart ! be patient : suffer not grief. For in the end This evening the morn becometh, and the night the dawn, Hafiz, when the musk of IIis tress-tip is in thine hand,

Indraw thy breath. If not, to the morning breeze news would be."

(ClARKE).

"Ruze ba chunan guzasht wa ruze ba chunin

Aknun ki nigah kuni, na an ast wa na in."

ANwAr-I-SuheILI.

" One day in this, the next in that goes by, Thou look'st, and now nor this not that canst spy."

EAstwick.

" Ruze budam mushtaqwar

Ta babinam dar bashar anwar-i-yar

Ta babinam qulzume dar qatra' $\theta$

Aftabe darj andar zarra'e."

JalaLuddin Rumi.

" One day I was filled with longing

To behold in human form the splendours of the Friend,

To witness the ocean gathered up into a drop,

The sun compressed into a single atom."

WHINFIELD.

" Ruze ki az madar tu zadi uriyan,

Khalqan hama khandan, tu budi giriyan,

Dar ruz wafatat ki jan bispari

Khalqan hama giriyan, tu bashi khandan."

" On parent knees, a naked new-born child

Weeping thou satst, when all around thee smiled;

So live, that sinking in thy last long sleep,

Calm thou mayst smile, when all around thee weep."

"Ruze ki charkh az gil-i-ma kuzaha kunad

SIR W. JoNes. Zinhar, kasa'e sar-i-ma pur sharab kun." 
"When Fate at last makes flagons of my clay,

With wine, forget not, fill niy skull that clay." BıсkNeı.l.

" Ruze ki jaza-e-har sifat khwahad bud

Qadr-i-tu ba qadr-i-m'arifat khwahad bud,

Dar hasan sifat kush ki dar ruz-i-jaza

Hashr-i-tu basurat-i-sifat khwahad bud."

OMAR KinavvaM.

"On the dread day of final scrutiny

As in thy wisdom so thy meed shall be, Strive to get virtues here, for thou wilt rise

Bearing the imprint of thy quality." . (WHinfleLD).

" Ruze ki shawad 'idha 'ssama'u 'nfarat,'

Wa andam ki shawad 'idha 'nnujumi 'nkadarat'

Man daman-i-tu bigiram andar arsat

Guyam sanama 'biayya zanbin qutilat.'"

OMAR KHaYYam.

" On that dread day when wrath shall rend the sky,

And darkness dim the bright stars' galaxy,

I'll seize the Loved One by the skirt and cry,

"Why hast thou doomed these guiltless ones to die?",

(VIHINFIELD).

" Ruzgar ast ki az ghaiyat bi dad dar u

Nist mumkin ki kase ra sar wa saman bashad

Chashm-i-niki za ki darim ba ahde ki dar u

Gar kase bad na kunad, ghayat-i-ihsan bashad." Avwar-I-SuhEil.t.

"Such is the age that from cxcess of wrong

The life or goods of none secure can be,

To whom can we attribute kindness 'mid a throng

Who think they do a favour not to injure thee." EAstwick.

" Ruz-i-awwal ki sar-i-zulf-i-tu didam guftam

Ki pareshana'e in silsila ra akhir nist."

HAFIZ.

"The first day when I beheld Thy tress-tip, I spake

Saying "End to this chain's confusion is not." Clarke.

" Ruz-i-marg chu tabut-i-man rawan bashad

Guman mabar ki mara dil dar in jahan bashad,

Bara'e man ma giri wa magu 'Darigh I Darigh !'

Badam-i-div dar ufti, darigh an bashad." Dnwa-r-Shams-1-Tanriz.

" When my bier moveth on the day of death, Think not my heart is in this world,

Do not weep for me, and cry, 'Woe ! Woe!'

Thou wilt fall in the devil's snare; that is woe."

(Nicilol.SON). 
“ Ruz-i-wasl-i-dustdaran yad bad, Yad bad an ruzgaran yad bad, Garchi yaran farighand az yad-i-man Az man ishanra hazaran yad bad Raz-i-Haflz b'ad az in nagufta manad Ey darigh an razdaran yad bad."

Hafiz Odes.

"That day of friendship when we met recall, Recall those days of fond regret, recall ! My friends it may be have forgotten long But I a thousand times that throng recall, No more from Hafiz' lips shall secrets pass ;

Those who once kept them'I alas, recall." (BICKNELL).

"Ruz mahshar har nihan paida shawad

Ham za khud har mujrime ruswa shawad

Dast wa pa bidihad gawahi ba bayan

Bar fasad-i-u ba pish must 'aan

Dast guyad man chunin duzdida am

Lab baguyad man chunin busida am

Pa guyad man shudastam tamana

Farj guyad man bikardastam zina ;

Chashm guyad ghamza kardastam haram

Gush guyad chida am su 'alkalam

Pas darugh amad za sar ta pa wa khwish

Chun gawahi midihad "aza za pish."

JaLALUdDIN Rum.

" On the resurrection day all secrets will be disclosed, Yea, every guilty one will be convicted by himself, Hand and foot will bear testimony openly

Before the Almighty concerning their owner's sins. Hand will say, 'I stole such and such things,'

Lip will say, 'I asked for such and such things,'

Foot will say, 'I went after my own desires,'

Arm will say, 'I embraced the harlot,'

Eye will say, 'I looked after forbidden things,'

Ear will say, ' I listened to evil talk.'

Thus the man will be shown to be a liar from head to foot

Since his own members will prove him to be a liar."

(WHINFIELD).

\footnotetext{
" Ruz wa shab afsana jui ya tu chust, Juzu juzu tu fasana-gui t'ust Juzu juzwat ta barastast az 'adam, Chand shadi dida and wa chand gham, Z'anki bi lazzat na roiad hich juzu Balki laghar gardad az har pich juzu."
} 
"Day and night you are eagerly asking for news, Whilst every member of your body is telling you news, Since each member of your body issued from Not-being, How much pleasure, has it seen and how much pain? For no memler grows and flourishes without pleasure, And each member is weakened lyy every pain." (WHINFIEL.D).

"Saadia, mard-i-nik nam na mirad hargiz

Murda an ast ki namash ba nikui na barand." ANwAr-I.SUIEIL.

"Sadi, he whose fanc lives can ne'er be dead,

He dies whose good name is dishonoured." EAstwick.

"Saari'u ila maghflratin min rabbikum wa jannatin ardhuha 'ssamawatu wa'l'ardhu 'uiddat lilmuttaqin 'lladhina yunflquna fl 'ssarra' 1 wa 'dhdharra'i wa 'Ikadhimina 'Ighaidha wa 'l'afina 'ani 'nnasi wa 'llahu yuhibbu 'lmuhsinin."

"Vie in haste for pardon from your Lord, and a Paradise vast as the heavens and the earth, prepared for the Gorl-fearing, who give alms alike in prosperity and in distress, and who master their anger and forgive others. (And God loveth the doers of good.") (RoDwel.).

"Sabilu 'lmauti ghayatu kulli hayyin fada'ihi l'ahli l'ardhi da'i Wa man la yu'tabat yas'am wa yahram wa tusilmahu 'Imanun ila 'nqita'1." Katarı.

"The pathway of death is set for all men to travel,

The Crier of death proclaims throughout the earth his empire,

Who dies not when young and sound, dies old and weary,

Cut of in his length of days from all love and kindness."

"Sad andakhti tir wa har sad khata'st,

C. J. Lyall. Agar hushmandi, yak andaz rast."

BostaN OF S'ADI, chap. 7 .

"Thou didst cast a hundred arrows and each one of the hundred is a miss, If thou art wise, cast one straight."

(Cl.ARKE).

"Sad dall aurad muqallid dar bayan

Az qiyasi guyad ura na z'aiyan;

Mashk aludast ama mashk nai

Bue mashkastash wall juz pashk nai."

JALALUDDIN RUMI.

"Though the mere imitator quntes a hundred proofs,

They are all based on opinion, not on conviction.

He is only scented with musk, he is not himself musk,

He smells of musk but is really naught but dung."

"Sad hazaran dam wa danast ai khuda

(WHINFIELD).

Ma chu murghan haris wa binawa;

Damba dam ma basta-e-dam nau im

Har eki kar baz wa Simurghe shawim.

Mi rihani har dami mara wa baz,

Sul dami me rawim, ey sarfaraz."

Masnavi, Book I. 
" O God there are hundreds of snares and baits And we are even as greedy and foolish birds ; Every moment our feet are caught in a fresh snare, Yea, each one of us though he be a falcon or Simurgh, Thou dost release us every moment and straightway We again fly into the snare, O Almighty one." Whinfielo.

"Sad hazaran niza'e Firaun ra Dar shikast an Musa ba yak asa Sad hazaran tibb Jalenus bud Pish Isa wa dam ash afsus bud Sad harazaran daftar ash'ar bud Pish harf ummi ash 'ar bud."

JALALUDDIN RUmL.

"The million spears of Pharaoh vaunting in his might, By Moses' wand were broken in the appointed night: And many sons of skill, for healing science famed By Jesu's curing halt, lame, blind, deaf, mad, were shamed; How many poets, orators, great men of note, By word of the Illiterate One * were shown to dote."

(REDHOUSE).

"Safahna 'an bani Dhulin wa qulna 'lqaumu 'ikhwanu 'Asa 'l'ayyamu 'an yarj'ina qauman ka'lladhi kanu Falamma sarraha 'shsharru fa'amsa wa huwa 'uriyanu Wa lam yabka siwa 'l'udwani dinnahum kama danu."

Shahl.

"Forgiveness had he for Hind's sons, We said 'The men our brothers are : The days may bring that yet again They be the folk that once they were.' But when the III stood clear and plain And naked wrong was bare to-day, And naught was left but bitter hate, We paid them in the coin they gave." (C. J. Lyall).

"Safar "id bashad bar an kad khuda

Ki ba nawa'e zishtash buwad dar sara'e

Dar khurrami bar sara'e biband

Ki bang zan az wai bar ayad buland."

Bostan of S'adi.

"Travel is a festival to that house-master

In whose house is a wife of bad disposition ;

Shut the door of joyfulness on that house

From which the wife's clamour issues largely." (ClaRkE).

"Safar murabbi mard ast wa astana'e jah

Safar khazana'e mal ast wa ustad-i-hunar."

ANWAR-I-SUheIll.

"Travel man's tutor is and glory's gate, On travel treasure and instruction wait." EASTwick.

* Muhammed. 
"Sag ba daryae haftgana mashau

Kl chu tar shud palidtar bashad."

Gul.rsta.s, chap. 7.

"In the seven seas would'st thou a dog make clean, When wet, 'tis fouler than it erst has been." (EAsTwICK)..

" Sag-1-ashab-1-kahe ruze chand

Pai nikan girift wa mardam shud."

Gulistax, chap. 8.

"The cave-sleepers' dog some time remained

With good men and the rank of man attained."

(EAsTwick).

"Sahab qatra'e baran za kuh wa na girift

Wagarchi dar dil khara na mi kunad tasir."

ANwar-1-Suhelli.

"The clouds shower down their rain the hills upon,

Though in their stony breasts they nought effect.'

\section{EASTWICK.}

"Sakhara 'lbahra lit 'akulu minhu lahman tariyyan wa tastakhriju minhu hilyatan talbasunaha wa tara 'Ifulka mawakhira flhi litabtaghu min fadhlihi."

KORAN, chap. 16.

" He hath subjected the sea to you that ye nuay eat of its fresh fish, and take forth from it ornaments to wear, and thou seest the ships ploughing its billows, and that ye may go in quest of His bounties." (RoDweLL).

" Sakhawat kunad nikbakht ikhtiyar

Ki mard az sakhawat shawad bakhtiyar

Sakhawat mis-i-ajbra kimiyast

Sakhawat hama dardra dawast."

PandNama of S'MI).

"The fortunate maketh choice of liberality

Because a man is rendered happy thereby,

Liberality is the elixir for transmuting the copper of defect,

Liberality is the remedy for all ills." (GLADwiN).

"Sakht khak aluda miayad sukhan,

Ab tira shud, sar-1-chah band kun,

Ta khuda ash baz saf wa khush kunad,

Anki tira kard, ham safash kunad,

Sabr arad arzu, na shitab,

Sabr kun, wa Allah alim ba'sawab."

JALALUDDIN RUNI.

"The IVord is become foul with mingled earth,

The water is become nuuddy; close the mouth of the well,

Till God makes it again pure and sweet,

Yea, till He purifies what He has made foul;

Patience will accomplish thy desire, not haste,

Be patient, God knows what is best."

(WHINFIELD).

"Salah dini wa dunyast zan-i-nik

Zihi sa'adat marde ki zan chunin darad."

ANWAR-1-SUHEILI. 
" Sweet is the converse of a virtuous wife Happy his fate who such a spouse possesses."

"Salha bar tu bugzarad ki guzar

EASTWICK. Na kuni sue tarbat-i-pidarat Tu ba jae pidar che kardi khair Ta haman chashm dari az pisarat?" GuListan, chap. 6 .

" Long years, successive years have gone since thou didst visit at thy father's grave, What filial actions hast thou done, That from thy son thou shouldst like worship crave?"

"Salha pairaui-mazhab rindan kardam

(EASTWICK).

Ta bafatwa khirad hirs bazindan kardam;

Naqsh-i-masturi wa masti na badast-i-man wa tu'st

An chi Sultan-i-ażl guft 'bikun,' an kardam." Hafiz OdE, 407.

" Me many a year the reveller's path allured,

Till Reason's verdict my desire immured, To feast, to fast, rests not with thee or me, The Lord Eternal caused our acts to be." (BICKNELL).

"Salha raftam safar az "ishq mah

Bi khabar az rah wa hairan dar Allah

Pa barahna merawi bar khar wa sang

Guft man hairanam wa b'ikhwish wa nang

Az rah wa manzil, za kutah wa daraz

Dil chi danad k'ust mast dilnawaz."

JALAl.UDDIN RUMl.

"I journeyed years and months for love of that moon, Heedless of the way, absorbed in God, With bare feet I trod upon thorns and flints,

Seeing I was bewildered, and beside myself and senseless;

What knows the heart of road and stages,

What of distant and near, while it is drunk with love."

(WHINFIELD).

"Samih 'akhaka 'idha khalat minhu 'l'isabat bi'lghalat

Wa tajafa 'an t'anifhi 'in zagha yauman au qasat,

Wa'hfadh saniyaka 'indahu shakara 'ssaniyata 'am ghamat."

MaQAMAT OF HaRIRI.

"Pardon thy brother when he mingles his right aiming with error, And shrink from rebuking him if he swerve or decline,

Keep to thy kind dealing towards him whether he thank for the kindness or slight it."

(CHENery).

"Sang dar dast wa mar sar bar sang

Na kunad mard-i-hushyar dirang

Tarahhum bar palang-i-tiz dandan

Sitam kari buwad bar gusfandan."

Gulistan, chap. 8. 
"When a stone is in the hand; on a stone the serpent's pate, He is not a man of sense who to strike should hesitate.

To sharp-toothed tigers kind to be,

To harmless flocks is tyranny."

İASTWICK.

" Sange ba chand sal shawad l'al-i-para, Zinhar nafsash nashikani ba sangi."

Gubistax, chap. 8.

“'Tis years before the pebble can put on

The ruby's nature. Wilt thou on a stone

In one short moment mar what time has done."

"Sani bi chun chu 'alam afrid

Eastwick.

Aql awwal ra muqaddam afrid;

Dih bud silak aqul, ey khurda dan,

Wa an diham bashad muassir dar jahan;

Kar kun juwad ast dar giti tamam

Aql faalash az u kardand nam

U'st dar "alam mufaiyaz khair wa sharr

U'st dar giti kufail naf'a wa zarar."

Jami, Salaman and Absal.

"The Incomparable Creator when this world

Ile did create, created first of all

The First Intelligence. First of a chain

Of Ten Intelligences, of which the last

Sole agent is in this our universe

Active intelligence so called. The one

Distributor of evil and of gisod,

Of joy and sorrow."

E. Fitzcieral.D.

“Sara'e wa madr asa wa bahs-i-'ilm wa taq wa rawaq

Chi sud chun dil-i-dana wa chashm-i-bina nist?"

Hafiz.

"Collegiate halls and learned strifes where porch and arch are high, What profit they when wisdom tails or seeing eye is not?"

BickNel,

“Sar ki aqli az wai bipard dum shawad."

Jalaleddis Kum.

"The head whose reason has fled is a tail."

WIINFIEL.D.

" Sar ta sar afaq bahawan sudan,

Nih taq-i-falak bakhun-i-dil andudan,

Sad sal digar asir-i-zindan budan,

Bih z'an ki dame hamdam-1-nadan budan."

HAFIZ.

" The whole earth in a mortar to pound fine,

To smear thy heart's blood on heaven's arches nine,

To be immured a hundred years is less

Than with a fool one moment to combine."

BICKNEI.L. 
"Satafarraqu ummati "ala thalathni wa sabi'ina millatan kulluhum fi 'nnari illa millatun wahidatun."

Saving of Muhamad.

"My people will be divided into three and seventy sects, and all of them shall be in the Fire save one sect."

"Satudhri 'ddama la 'ddam'a, idha 'ayanta la jam'a

Yaqi fi 'arsati 'ljam'a, wa la khala wa la 'amm,

Ka 'anni bika tankhattu ila 'llahdi wa tanghatu, Waqad 'aslamaka 'rrahtu ila 'adhyaqa min samm, Hunaka 'ljismu mamdudun liyast'akilahu 'dudu, Ila an yankhara 'l'udu, wa yumsi 'l'adhmu qad ramm."

Hariri, Magamat, II.

" Thou shalt wcep blood not tears, when thou perceivest that no com. pany can protect thee in the Court of Assembling; no kinsman of father or mother.

It is as though I conld see thee when thou goest down to the vault and divest deep; when thy kinsmen have committed thee to a place narrower than a needle's eye,

There is the body stretched out that the worms may devour it until the coffin-wood is bored through anll the bones moulder." (CHENERY).

"Saya parwarda ra chi taqat-i-an

Ki rawad ba mubarizan baqital

Sust bazu ba jahl miafgand

Panja ba mard-i-ahani changal."

Gulistan, chap. 8.

"He who was nursed in soft repose

Cannot with warriors to the battle go;

Vain with his weakly arm to close

And struggle with an iron-wristed foe." EAstwick.

" Sayyad ki bar nagzarad az kunjishke

Dani chi kunad chu kabak wa tihu binad."

Anwar-i-Suheili.

"The fowler that not sparrows e'en will spare,

Think what he does when game and quails are there."

EASTWICK.

"Ser amadam ey khuda az pasta-e-khwish,

Az tang dili wa az tihi dasta-e-kwish

Az nist chu hast mekuni birun ar

Z'in nistiam ba hurmat-i-hasta-e-khwish."

Omar Khayvam.

" Lord, I am tired of this low state of mine,

This wretched lot, this beggary of mine;

Thou makest all from naught, bring me from naught, Into that sacred being which is thine."

(WhINFIELD). 
" Shab gurizad chunki nur amad za dur

Pas chi danad zulmat shab hal-j-nur

Pasha bigurizad za bad-i-badha

Pas chi danad pasha zauq badha;

Chun qadim ayad hadas gardad 'abas

Pas kuja danad qadimi ra hadas."

JALAT.LDUIN RUML

"When the day dawns from heaven, night flees away

What then can its darkness know of the nature of light?

The gnat scuds away before the blast of the winds,

What then knows the gnat of the savour of the winds?

When the Eternal appears, the transitory is annulled,

What then knows the transitory of the Eternal?"

"Shab-i-tarik-i-dustan-i-khuda

(WHINFIELD).

Mibitabad chu ruz-i-rakhshinda

Wa in sa'dat ba zur-i-bazu nist

Ta na bakhshad khuda'e bakhshinda."

Gulistan, chap. 8.

"The dark night of the friends of heaven

Shines with the brilliant light of day ;

Not to man's might is this rich blessing given,

It comes from God, no other way."

(EASTICK).

"Shab-i-tarik wa bim mauj wa girdabi chunin ha'il

Kuja danand hal-i-ma sabuk barani sahilaha."

HAFIZ.

"The waves are wild, the whirlpool dreadful, the shadow of the night steals o'er,

How can my fate excite compassion in the light-burdened of the shore?:"

"Shaha falakat bi khusrui $t$ 'ain kard

(BICKNELL.).

Wa za bahr-i-tu asp padshahi zin kard,

Ta dar harakat samand zarrin sum tu

Bar gil nihand pa-e-zamin simin kard."

OMak КнayYan.

" Oh Shah! heaven portioned sovereignty to thee,

And saddled power thy glorious steed to be,

And where thy charger sets his golden hoofs,

Earth glitters like some golden tapestry." (WhINFIELL).

"Shahra bih buwad az ta'at-i-sadsala wa zuhd

Qadri yak saata 'umri ki daru dad kunad."

HAF12.

"For better in a king one hour in deeds of justice passed,

Than piety and works austere that five-score years should last."

BICKNELL.

"Shakar bar tute fikun, murdar pish gurgan." Kasta AL ANWAR.

"Throw sugar to the parrot, but place carrion before the wolf."

(OUSELEY). 
"Shakh ki bi mewa buwad nakhush ast Matbakhan ra madad-i-atish ast."

ANWAR-1-SUHEILI.

"The barren branches do but shock the eye, And can but fuel to the cook supply."

EAsTwICk.

" Shakh-i-niki sa'adat arad bar

Gul na chinád kase ki karad khar

Chun yaqin shud jaza'e nafa 'wa zarar

Nikui kun ki nikui bihtar."

ANWar-I-SUheil..

" Joy's fruit upon the branch of kindness grows,

Who sows the bramble will not pluck the rose;

Since loss or gain are to our acts assigned,

Do good, for 'tis far better good to find." Eastwick.

" Shakhsam ba chashm-i-'aliman khub manzarast

Wa za khubs-i-batinam sar-i-khajlat nihada pish

Tausra ba naqsh wa nigari ki hast, khalq

Tahsin kunand, wa u khajal az pae zisht-i-khwish."

Gulistan, chap. 2.

" My person in men's eyes is fair to view

But for my inward faults shame bows my head;

The peacock lauded for his brilliant hue

Is by his ugly feet discomfited."

(EASTWICK).

"Shakhse hama shab ba sar-i-bimar grist

Chun ruz shud u bamurd wa bimar bazist."

Gulistan.

" A person wept the live-long night beside a sick man's bed ;

When it dawned the sick was well, and the mourner, he was dead."

(EAstwick).

"Sham'a parwana ra basukht wale

Zud buriyan shawad ba raugan-i-khwish."

Anwar-i-Suheir.I.

" The taper did the moth consume, 'tis true, Burned in its wax, it soon wili perish too." EAsTwICK.

"Shams dar kharij agarchi hast fard Mi-tawan ham misl-i-u taswir kard Shams-i-jan k'u kharij amad az asir Na bud ash dar zihn wa dar kharij nazir."

JaLALCDdin Rimo.

"Though the material sun is unique and single, We can conceive similar suns like to it, But the Sun of the soul beyond this firmament, No like thereof is seen in concrete or abstract." 
"Shamshir-i-nik za ahani bad chun kunad kase?

Na kas ba tarbiyat nashawad, ey hakim, kas

Baran ki dar latafat-i-tab'aash khilaf nist

Dar bagh lala roiyad wa dar bum khas."

Gulistan, chap. 1.

"Who can from faulty iron good swords frame?

Teaching, $\mathrm{O}$ sage, lends not the worthless worth,

The rain whose bounteous nature's still the same

Gives flowers in gardens, thorns in salt land birth.

(EASTWICK).

"Sharab-i-lutf-i-khudawandra kirane nist

Wa gar kiranash numayad qusur-i-jam buwad."

DIWAN-i-SIIAMS-I-TABRIZ.

"The wine of Goll's grace hath no brim,

If it appear to have a brim, 'tis the fault of the cup."

(Nicholsox).

"Sharafu'l makan bi 'l-makin."

Arabic Proverb.

"The dignity of the dwelling is in the dweller."

E. G. likow:NE.

"Sharru 'l'wara man yaumuhu 'akhsaru min 'amsihi."

MaqAMAT OF Hariri, chap. 4.

" The worst of men is he whose to-day falls slıort of his yesterday."

"Sharbat-i-angabin majui az dahr

(Chexery).

Ki bar amikhta ast shahd ba zahr,

Tu tasauwwir kuni ki an 'asal ast,

Wa an "asal nist, 'asal jalist."

ANWAR-t.StheIL.

" Think not sweet sherbet from the world to drink,

Honey with poison is commingled there,

That which thou fondly dost sweet honey think

Is but the deadly potion of despair."

Eastwick.

" Sharmat niayad az in tabahi kardan

Z'in tark-i-awamir wa nawahi kardan, Giram ki sarasar injahan mulk-i-tu shud

Juz an ki riha kuni, chi khwaht kardan?"

Ouar Kunviay.

"Have you no shame for all the ill you do?

Sins of omission and commission too?

Suppose you gain the world, you can but leave it,

You cannot carry it away with you." " WHINFIELD.

\section{"Sharra 'ddawabbi ind 'llahi 'osumu 'lbukmu 'lladhina la ya"qilun." \\ KORAN, chap. 7 .}

"The vilest beasts in God's sight are the deaf, the dumb who understand not."

(RODWELL). 
"Sh'ar wa hirs dani chist An yake tifl wa an digar daya."

"Dost thou know what poetry and covetousness are? The former is the child and the latter the nurse."

"Sheikhe bazan-i-fahisha gufta 'Masti ;

(E. G. Browne).

Har lahza badam-i-digare pa basti,'

Gufta 'Sheikha har anchi grui, hastam,

Amma tu chunanki me numai hasti?'"

Onar Khayyam.

"A Shaikh beheld a harlot and quoth he,

'You seem a slave to drink and lechery ;'

And she made answer, "What I seem, I am,

But, Master, are you all you seem to be?" "WHINFIELD.

"Sher ra salsala dar gardan wa ruba hama shab

Farigh ul bal bar atlal wa daman migardad."

ANWAR-I*SuMEILI

"The chain is on the lion's neck while the jackal all night long,

With thoughtless freedom ranges the ruined wastes among."

EASTWICK.

"Shigufa gah shiguftast, gah khushida,

Darakht waqt barahna wa waqt pushida." Gulistan, chap. 2.

"The bud now blossoms ; withered now is found ;

The tree now naked, now with leaves is crowned."

(EASTWICK).

"Shikam band dast ast wa zanjir-i-pae

Shikam banda kamtar parastad khuda'e." Gulistan, chap. 8.

"The belly binds the hands, the feet unnerves,

IIe heeds not heaven who his belly serves." (EAstwick).

"Shikasta qadah gar bi bandand chust

Ni aurd khwahad baha'e durust."

Bostan of S'Adi, chap. 9.

" If they cleverly piece together the broken goblet,

It wili not fetch the price of the perfect one." Clarke.

" Shukr qadarash qudratat afzun kunad,

Jabr ni‘amat az guft birun kunad;

Jabr-i-tu khuftan buad dar rah, makhusp,

Ta bini an dar wa dargah, makhusp."

JALALUDDIN RUMI.

" Giving thanks for blessing increases blessings

But fatalism snatches those blessings from your hands,

Vour fatalism is to sleep on the road; sleep not

Till ye behold the gate of the king's palace." Whinfield. 
"Shuma dilha nigah darid, man bar, Musalmanan,

Chunan amikhtam ba $u$, ki dil ba man niamizad, Nukhust az ishq-i-u zadam, ba akhir dil badu dadam,

Chu mewa zayad az shakhi, badan shakh andar awizad."

DIWAN-1-SแAMS-1-TABRIZ.

"Look to jour hearts! I whatever letide, O Moslems, Am so mingled with Him, that no beart is mingled with me, I was born of His love at the first, I gave Him my love at the last, When the fruit springs from the bough, on that bough it hangs."

"Shunidam ki dar ruzgar-i-qadim

(Nicholsox).

Shude sang dar dast-i-abdal sim ;

Na pirdari in qaul m'aqul nist

Chu razi shudi, sim wa sangat yak ast." Bostan of S'Adi, chap. 6.

"I heard that in ancient times

A stone used, in the hands of the pious, to become silver;

Thou thinkest nut that this speech is unreasonable,

When thou becomest content, silver and stone are alike to thee."

" Shunidam ki mardan-i-rah-i-khuda

(CLAKKE).

Dil-i-dushmanan ham nakardand tang;

Tura kai muyassar shawad in maqam

Ki ba dustanat khilafast wa jang?"

Guistan, chap. 2.

" The men of God's true faith I've heard, Givere not the liearts e'en of their foes,

When will this station be conferred,

On thee who dost thy friends oppose?" (EAstwick).

" Shur bakhtan ba arzu khwahand

Muqbilanra zawal-i-n'imat wa jah

Gar na binad ba ruz shapparah chashm.

Chashma-e-aftab ra chi gunah?"

Gillastan, chap.

"The wretched long to witness the decay

Of fortune's favours to the happier few,

But though the bat be visionless by day,

Can we for this a fault or failing view

In the sun's fount of light?"

(EASTWICK).

" Shutur ba chashma-i-suzan birun na khwahad shud

Hasud-i-kham tama; gu darin hawas bi'gda'z."

DHAHIR.

"The camel will not go through the eye of a needle,

Bid thine envier with his crude ambitions melt in this vain endeavour."

" Sifle na khwahad digarera bakam

(E. G. Bкоw:E).

Khas nagzarad magasra ba jam

Bi-hunaran sad hil arand pish

Ta na rawad kar-i-hunarmand pish."

ANWAR-1-St'HELLI. 
"The mean man grudges others their success, And so the miser would the fly expel

From the same cup. Endless the tricks, finesse, That knaves who neither act nor prosper well, Will try, lest fortune should true merit bless."

EAsTwick.

“ Sikandar-ra na mi-bakhshand abe Bazur wa zar muyassar nist in kar Khirad harchand naqdi-ka'inat ast Chi sanjad pish ishq kimiagar?"

HAF1Z OnE. 282.

"In vain Sikandar for the water sighs, Nor gold nor strength gains access to the prize; Though reason's coin may in the world assist, What is it, weighed by Love the Alchemist?" Bickneli.

" Sim-i-bakhil waqte az khak bar ayad ki way ba khak dar ayad." Gulstax, chap. 7 .

" The silver of the miser is disinterred when he is interred."

(EAstrick).

"Simurgh war chun natawan kard qasd-i-Qaf

Chun s'awa khurd bash wa faru gir bal wa par." Sultan Timook.

"If thou canst not soar like the Simurgh to the heights of the Caucasus, Be thou small like the sparrow, and fold up thy wings and feathers."

(KUKA).

"Sim wa zar bar ma la shai ast wa bi miqdar Dilast matlab-i-ma gar mara talabgari, $\mathrm{Za}$ 'arsh wa kursi wa lauh wa qalam fazun bashad Dile kharab ki anra kahi bishumari." DiwaN-I-Shams-1-TanRiz.

" Nor gold nor silver seek I but above All gifts, the heart, and buy it with iny love, lea! one sad contrite heart which men despise, More than my throne and fixed decree I prize."

(FAICONER).

\section{“ Sirrat hama Danạ'e falak midanad}

K'u mui ba mui warak baraq midanad

Giram ki ba ziraq khalqra bi faribi

Ba u chi kuni ki yak ba yak midanad."

ANWAR-1-SUHEILI.

"Heaven's Sovereign Lord knows all thy mystery,

He can thy every hair and vein descry,

Granted thy wiles may blind thy fellow-man,

Can they cheat Him who does all nature scan?"

EASTW:CK. 
" Sirr az hama nakasan nihan bayad dasht,

Raz az hama ablahan nihan bayad dasht, Bingar ki ba jae marduman chi kuni

Chashm az hama marduman nihan bayad dasht."

Omar Kinavia.

"To knaves thy secret we must not confide,

To comprehend it is to fools denied ;

See then to what harl case Thou doomest men,

Our hopes from one and all perforce we hide."

(WIINGJELD).

“Sirre k'ash az dushman nihuftan lazim ast

Bih ki az afsha'i an ba dusti kam dam zani ;

Dida am bisyar k'az sair sipar kaj nihad

Dustan dushman shawand wa dustiha dushmani."

Jam, Bmakistan, 2.

"A secret necessary to be concealed from a foe,

Thou wilt do well not to reveal it even to a friend;

I have seen many who in course of capricious time

Became foes from friends, and amity to enmity turned."

REHATSEK.

"Siru fl 'l'ardhi fa 'ndhuru kaifa kana 'aqibatu 'Imujrimin."

KORAN, chap. 27.

"Go ye through the land and sce what hath been the end of the wicked."

(ROINELL).

" Sitam-kash gar ahe bar arad za dil

Zanad suz-i-u shu'ala dar ab wa gil

Makun bar z'aifan bichara zur

Bi andish akhir za tangi gur."

Pand-Nama OP Stadi.

"If the oppressed sendeth out from his heart one sigh,

The heat thereot will set in flames both sea and land;

Oppress not the weak who are incapals]e of making resisiance,

Think of the end and of the punishment in the grave."

Glanmix.

.4 Sitanad zaban az rakiban-i-raz

Ki ta raz-i-Sultan na guyand baz."

Nizant.

"Ile taketh the tongue from such as share the inystery,

So that they may not repeat the king's secret."

(E. G. Browse).

"Situn-i-khirad burdbari buwad

Subuk-sar hamesha ba khwari buwad."

ANWAR-T-SUHETLI.

"In patience reason's prop we see, And man disgraced by levity."

EASTWLK. 
"Subhan 'lladhi 'asra biabdihi lailan mina 'lmasjidi 'lharami ila. 'Imasjidi 'la'qsa 'lladhi barakna haulahu linuriyahu min aiyatina. innahu huwa ssami'u 'lbasir."

"I declare the glory of Him who transported His servant ly night from the sacred temple to the temple that is more remote, whose precinct we have blessed that we might show him of our signs! He verily is theHearer, the Belolder." KURAN, chap. xvii. $\checkmark \cdot$ I

" Subhast, saqia, qadahe pur sharab kun, Daur-i-falak dirang na darad, shitab kun, Z'an peshtar ki 'alam-i-fani shawad kharab, Ma ra zi jam-i-bada'e gulgun kharab kun Ruze ki charkh az gil-i-ma kuzaha kunad, Zinhar, kasa'e sar-i-ma pur sharab kun."

HaFjz ODE, 459 .

" 'Tis morn, O Saki, fill the wine-cup high, Be quick; the heavens delay not as they fly, Ere yet this fading world to ruin goes My senses ruin with thy wine of rose. When Fate at last makes flagons of my clay With wine, forget not, fill niy skull that day."

(BICKNel.1.).

"Sud wa ziyan wa maya chu khwahad shudan zi dast

Gu bahar in mu'amala ghamgin mabash wa shad

Badat badast bashad, agar dil nihi bahich,

Dar m'araza ki takht-i-Suleiman rawad babad

Bi khar gul na bashad, wa bi nish nush ham Tadbir chist? waz'a-i-jahan inchunin futad."

HAFIZ Ode, 264.

"As loss and gain and capital shall soon no more be thine, Whatever to thy lot may fall, rejoice not nor repine,

When the heart's hope on Nothing rests, the hand grasps wind alone, In this abode where wind has swept from Solomon his throne,

Upon the rose the thorn is found, a sting in honey lurks, What counsel can avail us aught? This law in all things works."

"Sue tigh ishqash ey nang-i-zaman (BICKNELL).

Sad hazaran jan nigar dastak zanan,

Jui didi, kuza andar jui riz

Abra az jue kai bashad guriz?

Ab kuza chun dar ab ju shawad

Mahw gardad dar wai wa ju u shawad."

JALALUdDin RUms.

" $O$ base one, behold a hundred thousand souls

Dancing towards the deadly sword of his love,

Behold water in a pitcher; pour it out;

Will that water run away from the stream?

When that water joins the water of the stream

It is lost therein and becomes itself the stream."

WHINFIELD. 
Sufl ibn-ul-waqt bashad dar misal

Lek safl farigh ast az waqt wa hal ;

Halaha mauquf flkr wa rae-i-u

Zinda az nafah Masih asae u ;

Ashiq hali na ashiq bar mani

Bar ummid hal bar man me tani."

"The Sufi is as it were, the 'son of the season'

liut the pure is exalted above season and stale, lieligious raptures depend on feelings and will

Int the pure onc is regenerated by the brealh of Jcsus,

lou are a lover of your own raptures, not of me,

lou turn to me only in hope of experiencing raptures."

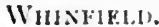

"Suhbat-i-ablahan chu digh tihist

K'az dirun thall az birun siyahast."

ANWAR-1-St'HUILI.

"Fools' company like to an empty pot Is black without and aught within is not." Eastwick.

" Suhbat-i-an kas ki ba sidq wa safa'st

Daman-i-u gir ki ahl wafa'st

Mail kase kun ki wafayat kunad

Jan sipar-i-tir-i-balayat kunad ;

Bahri chunan dust ki jani buwad

Dusti jan za girani buwad."

AN!WAK+1-SLHE.II.1.

"Whose converse is sincere and free from wile, Grasp thou his skirt for he will faithful be ; And seek the man whose acls are void of guile, Who against fortune's arrow would shield thee With life. Friends who at core devoted arc, Their love than life itself is dearer tar."

EASTWICK.

"Suhbat-i-shahra za rue qiyas

Hamchu darya'e bi-girana shinas

Ba chunin bahr pur za khauf wa khatar Har ki nazdiktar parishantar."

ANWAR-I.Sthell.1,

" IVould'st thou judge right of princes' company,

Then view it as a vast and shoreless sea;

To such an ocean full of risk and fear,

Most wretched aje the man that is most near."

EAsTw1CK.

“ Suhbat-i-yaran ghanimat dan ki naqd-i-zindagi

Khass az bahri nisar suhbat-1-yaran khushast

Khush buwad bahri tamasha'e gulshan umr aziz

Wa an tamasha ham ba didar hawadaran khushast."

ANWAR+1.StHELL. 
" Prize high the converse of thy friends, for know, the coin of life-time here Was given but to scatter at the feet of those that we hold dear, Oh life is precious, but to view the flowers that in the world appear, This spectacle is joyous but when friends and those we love are near."

" Sukhan angah kunad hakim aghaz

EASTWICK.

Ya sar-i-angusht sue luqma daraz

Ki za na guftanash khalal zayad

Ya za nakhurdanash bajan ayad

La jurm hikmatash buad guftar

Khurdanash tandurusti arad bar."

Gulistan, chap. 3 .

"The wise will then begin their speech,

Then towards food their fingers reach,

When silence would with ills be rife

When fasting would endanger life;

Such speech were, certes, wisdom too,

And from such food will health accrue." (EAsTwick).

\section{" Sukhan dan-i-parwarda pir-1-kuhan}

$B i$ andishad angah baguyad sukhan

Mazan bi-taammul ba guftar dam

Niku gui gar der gui, chi gham?"

Gulistan, Preface.

"The well-taught orators, the men of age

First ponder well, and then their thoughts declare,

Waste not thy breath in thoughtless speech; if sage

Thy counsel, slowness will it nought impair." (EAS'l WICK).

"Sukhan div bandist dar chah-1-dil

Ba bala'e kam wa zabanash ma hil."

Bostan of S'AD1, chap. 7 .

" Speech is a demon confined in the heart's well,

Let it not go to the height of palate and tongue."

"Sukhan durr ast wa taalluq ba gush-1-Shah darad."

(CrakKE).

ANWAR-1-SUHEIL1.

"Speech is a pearl befits the ear of kings." Eastwick.

" Sukhan-i-shah shahhar sukhan ast."

AKHLAQ-1-MLHSini.

"The word of a king is the King of words." Klisxe.

"Sukhan ta na gui, bar u dast hast,

Chu gufta shawad, yabad u bar tu dast." Bostan of S'Aul, chap. 7 .

"So long as thou utterest not speech, to thee there is power over it, When it becomes uttered, it obtains mastery over thee." (CLARKE).

"Sukhan ta na gufti tawanash guft

Wale gufta ra baz natawan nihuft,"

Anwar-J-Sthejh. 
"Thou canst the unsaid or say or else abstain, Once spoken, no concealment will remain." EAstwick.

" Sukuni badast awar ai bi sabat

Ki basang-i-girdan na roiad nabat."

Bostan of S'Adi, chap. 6.

"O one without permanence bring tranquility" to thy hand, For vegetation grows not on the rolling stone." (CI.ARKE).

"Sulh tzdad ast umr in Jahan."

Jataltidis RUan.

"The life of this world is a truce between opposites."

" Sunnate banihad za asbab wa tarq

Taliban ra zir in nile tutuq

Ey giriftar-i-sabab birun mabar

Lek azal an Musabbib zan mabar

Ba sababha az Musabbib ghafli

Sue in rupushaha z'an mail'i."

ANWAR+I-SUHEILI.

"To study ways and means is Gol's decree,

To all beneath the sky's blue canopy;

By causes chainer, seek not from cause to fly,

Vet doubt not the first Cause is Deity,

Art thoul through causes to their Cause supine,

Can'st thou from Him to those veiled ones incline?"

"Sunnat ma kun wa farizhara bugzar

Wa an luqma ki dari za kasan baz madar

Ghaibat makun wa majui kasra azar

Ham wada-e-an Jahan manam bada biar."

Omar Khaypam.

"Heed not traditions, forms or discipline, So that you injure none, and none malign, And ne'er withhold your store from worthy men, I guarantee you heaven, -and now some wine."

"Surat az bisurati amad birun,

(WHINFIEIA).

Baz shud ' $k$ 'anna alaihi raj'iun;'

Pas tura har lahza marg raj'atist

Mustafa farmud duny a sa'atist ;

Fikr-1-ma tirast az Hu dar hawa,

Dar hawa kal payad, ayad ta khuda."

JALALUEDIN RUMH.

"Form is born of that which is without form,

Wherefore to thee every noment comes death and 'return,'

Minstafa " saith 'The world endureth only a moment,'

So thought is an arrow shot by God into the air,

IIow can it stay in the air? It returns to G(xl." WhINF(El.).

" "The chosen one," i.e., Muhammad. 


\section{"Suratgar-i-naqqasham, har lahza bute sazam \\ Wa angah hama buthara dar pish-i-tu bigdazam \\ Sad naqsh bar angizam, ba ruh dar amizam \\ Chun naqsh-i-tura binam dar atishash andazam, \\ Tu saqi khammari ya dushman-i-hushyari \\ Ya anki kuni wiran har khana ki bar sazam \\ Jan rikhta shud ba tu, amikhta shud ba tu, \\ Chun bui tu darad, jan janra hala binawazam."}

Diwan-I-SHaMs-I-Tabiziz.

"I am a painter, a maker of pictures; every moment I shape a beauteous form,

And then in thy presence I melt them all away.

I call up a hundred phantoms and endue them with a spirit

When I behold thy phantom, I cast them in the fire,

Art thou the vintner's cup-bearer or the enemy of him who is solver,

Or is it thou who mak'st a ruin of every house I buili?

In thee the soul is dissolved, with thee it is mingled,

So I will cherish the soul, because it has a perfume of thee."

(Nicholson).

“Ta 'azza fa'inna 'ssabra bilhurri aj malu wa laisa 'ala raibi 'zzamani mu'awallu."

IBRAHIM IHN KUNAIF.

"Be patient; for free-born men to bear is the fairest thing,

And refuge against time's wrong and help from his hurt is none."

C. J. LvalL.

" Ta ba dukan wa khana dar girawi

Hargiz ey kham, admi na shawi,

Birau, andar-i-jahan taffaraj kun,

Pish az an ruz k'az jahan birawi."

Gulistan, chap. 3 .

" Whilst thou art wedded to thy shop and home,

O simpleton ! a man thou ne'er wilt he ;

Go blithely forth and in the wide world roam,

Ere thou roam'st from it to eternity."

(EASTMICK).

“Ta bitawani ranja magardan kasra,

Bar atish-i-khashm-i-khwish manshan kasra,

Gar rahat-i-jawidan tam'a medari

Meranj hamesha wa maranjan kasra."

OMAR Khatran.

" Whate'er thou doest, never grieve thy brother,

Nor kindle fumes of wrath his peace to smother,

Dost thou desire to taste eternal bliss,

Vex thine own heart, but never vex another."

(WH!NFIELD).

- Tabban litalibi dunya, thanna alaiha 'nsibabihi

Wa lau dara, lakafahu mimma yarumu sababihi." 
A' Woe to him who seeks the world and turns to it his careering,

Oh, if he were wise, but a drop of what he seeks would content him!"

(CHesekY).

"Ta dil-i-dustan badast ari, bustan-i-pidr farukhtan bih,

Pukhtan-i-dig-i-nik khwahanra har chi rakht-i-sar ast sukhta bih

Ba badandish ham niku'i kun, dihan-i-sag ba luqma dukhta bih."

Gillstan, chap. r.

" To gain thy friends' affection, sell the garden of thy sire ;

To gain them food, protection, with thy goods go feed the fire,

Show kindness even to thy foes, the dog's mouth with a morsel closc."

(EASTWICK).

"Tafawut kunad hargiz ab-i-zilal,

Garash kuza zarrin buwad ya sifal ?

Khirad bayad andar sar-1-mard wa maghz

Na bayad mara chun tu dastar naghaz." Bostan of S'ADI, chap. 4.

"Is drinking water ever different

If its vessel be golden or earthen?

Wisdom and lrain within man's head are necessary,

For me, like thee, a beautiful turban is unnecessary."

(ClaRke).

“Ta gham na khurad wa dard nayafzad qadr mard

Ta l'al khun na kard jigar qimate na yaft;

Az nama'e sa'adat khud mard rah-rau

Bi dagh-i-mihnati raqm daulate na yaft."

ANWAR-I-SLIEHI.

"None will be honoured till they suffer grief and toil and pain,

The ruby must effuse its heart's blood, ere it value gain,

Ne'er did the traveller trace out in the scroll of happiness,

Clear from blot of toil and troulle, the handwriting of success."

"Tahammul chu zahrat numayad nakhust

Wall shahd gardad chu dar tab'a rust." Bostan of S'ADI, chap. 4.

EASTWICK.

" Endurance appears, at first, to thee like poison, But when it grows in the disposition it becomes honey."

“Tahammul kunad sar har ki ra aql hast Na aqle ki khashmash kunad zir-i-dast."

(CLARKE).

ANWAR+T-SLHEILI.

"Ife that is ratonal, is patient too, But senseless he whom anger masters." EAsTwick.

"Ta hushyaram tarab za man pinhan ast Chun mast shudam dar khiradam miqsan ast, Hal ist miyan-i-masti wa hushyari

Man banda-e-an ki zindagani-an ast."

Omar kihaviam. 
"Sobriety doth rob me of delight, And drunkenness doth drown my sense outright; There is a middle state, it is my life, Nor altogether drunk, nor sober quite." (WHINFIELD).

“Tajir tarsanda tab'a shisha jan Dar talab na sud darad na ziyan; Bal ziyan darad ki mahrumast wa khwar, Nur u yadad ki bashad shu'ala khwar."

"The lamp of the heart that is a timid trader Acquires neither loss nor gain by its ventures, Nay it acquires loss, for it is precluded from gain, "Tis the lamp that takes fire that acquires light."

WHINFIELD.

Ta khak mara baqalib amikhta and

Bas fitna ki az khak bar angikhta and

Man bihtar az in na mi tawanam budan

K'az buta mara chunin birun rikhta and."

OMAR KHAYYAM.

"When the great Founcler moulded me of old, He mixed much baser metal with my gold;

Better or fairer I can never be,

Than what I was when fresh from Allah's mould."

(WHINFIELD).

"Talattuf kun ki har kare ki s'ab ast

Ba narmi wa madar mi-tawan sakht."

ANwar-I-SUHEILI.

" Be mild for things though hard and troublous too,

Thou may'st by kindness and by mildness do." EASTwICK.

“ Ta mard sukhan nagufta bashad

Aib wa hunarash nihufta bashad

Har bisha guman ma bar ki khalist

Shayad ki palang khufta bashad."

Gulistan, chap. 1.

“ While a man's say is yet unsaid,

His weakness, merits none descry;

Think not each waste untenanted,

A sleeping tiger there may lie."

(EASTWICK).

"Tanahi 'ssabr mudh nallat bimawa 'las di sirhan

Wa tara 'laqlu idh ghannat bil maghna 'lwurqi ghurban." Hafiz.

"All patience has fled for the wolf abides where the lion before was found, Reason, driven away has fled, ravens' notes for pigeons sound."

“Ta na kubi gandam andar asya

Kai shawad arasta z'an khwan-i-ma?"

(BICKNELL).

" Till the corn be ground with the mill, how can our table be furnished with bread?" 
" Tangi mai I'al khwaham wa diwani

Sadd-i-ramaqi bayad wa nisf-i-nani,

Wa angah man wa tu nishasta dar wirani

Khushtar bud az mamlukat-i-Sultani."

Omar Khayyam.

"Give me a skin of wine, a crust of bread, A pittance bare, a book of verse to read, With thee, O love, to share my solitude, I would not take the Sultan's realm instead."

IVHINFIELD.

“Tan za jan wa jan za tan mastur nist,

Lok kasra did jan dastur nist."

JaLAi.UdDIN RUMi.

"Body is not veiled from soul, neither soul from lody,

Yet no man hath ever seen a soul."

(WHINIIELD).

“Tariqat bajuz khidmat-1-khalq nist

Ba tasbih wa sajja wa dalaq nist."

Bostan of $\mathrm{S}^{\prime} \mathrm{ADI}$, chap. 1.

" Religion is only in the service of the people,

It is not in the rosary and the prayer-carpet and the darwesh-garment."

(CLARKE).

“Tarsam na rasi ba ka'aba ey a'rabi!

K'in rah ki tu merawi ba Turkistan ast." GuLisTan, chap. 2.

“ $O$, Arab, nuch I fear that thou at Mecca's shrine will never be, For the road that thou art going is the road to Tartary."

(EASTWICK).

“ Tars-i-ajal wa wahm-i-fana masti tu'st

Warna za fana shakh-i-baqa khwahad rust,

Ta az dam-i-Isawi shudam zinda ba jan

Marg-1-abad az wujud-i-man dast bashust." OMar KhaYyan.

“ Death's terrors spring from baseless phin'asy,

Death yields the tree of immortality;

Since Jesus breathed new life into my soul, Eternal death has washed its hands of me."

(WHINFIELD).

“ Tartaqa 'anfusina b'ilittaqa

Mutuhafan mina 'ala daru 'lbaqa,

Thumma yatina makafatu 'imaqal

Dh'af dhaka rahmata min dhu 'ljalal

Thumma yaljaina al 'amthallha

Kai yanalu 'l'abad mima naliha

Hakadha taarraj wa tanazzul da ima

Dha fala zalat alaibi qaima."

Jalal.UdDin RUim. 
" Our breathings are lifted up in fear of God, Offerings from us to the throne of Eternity, Then come down to us rewards for our praises The double thereof yea mercies from the king of glory, Therefore are we constrained to utter these praises That slaves may attain the height of God's gifts, And so this rising and descent go on evermore, And cease not for ever and aye."

(WHINFIELD).

"Ta tawan bar masnad-i-izzat nihadan pa'e khwish Az chi bayad kard dar khak-i-mazillat ja' $\Theta$ khwish."

ANwAR-1-ŚUheIL.1.

"On honour's cushion till our foot we place, Why in the dust sit down of foul disgrace." EAstwick.

"Ta tiryak az Iraq awarda shawad mar-guzida murda buwad."

Gulistan, chap. I.

" Before the antidote is brought from Trak, the person who is bitten by the snake may be dead."

(EASTWICK).

"Ta tawani dirun-i-kas makharash

K'andarin rah kharha bashad;

Kar-i-darwish mustmand bar ar

Ki tura niz karha bashad."

Gulistan, chap. .

"Strive not to pain a single heart

Nor by that thorny pathway move;

But with the needy aye take part;

To thee too this will succour prove."

(EASTwick).

"Tawaf-i-k'aba'e dil kun agar dile dari

Dilast k'aba'e m'ana, chu gil chi pindari?

Tawaf-i-k'aba'e surat haqqat badan farmud

Ki ta ba wasta'e an dile bidast ari

Hazar bar piyada tawaf-i-K'aba kuni

Qabul-1-haqq na shawad gar dile biazari." Drwan-I-Shams-I-TABRIz.

" Beats there a heart within that breast of thine,

Then compass rev'rently its sacred shrine :

For the true spiritual K'aba is the heart

And no proud pile of perishable art,

$\mathrm{W}^{\mathrm{T}}$ hen God ordained the pilgrim rite, that sign

Was meant to lead thy heart to things divine,

A thousand times he treads that round in vain,

IVo e'en one human heart would idly pain."

“Tawanam an ki niazaram andarun-i-kasi

(FALCONER).

Hasudra chi kunam ku zi khud baranj darast

Bimir ta birahi, ey hasud, kin ranjist

Ki az mashagqati-an juz ba marg natawan rast." 
"This can I do-inflict distress on none, Envy's its own distress-what can I there?

Perish $\mathrm{O}$ envious one! for thus alone Can'st thou escape from thy self-nurtured care."

" Tawan ba marham tadbir nik wa rae sawab Jarahat-i-dil sad para ra dawa kardan."

(EAstinick).

"With the salve of happy counsel and of schemes that aim aright, Be the heart in fragments shivered there is healing for its plight." EASTWICK.

" Tawangara dil-i-darwish-1-khud badast awar,

Ki makhzan-i-zar wa ganj-i-diram na khwahad mand Bar in riwaq-1-zabarjad nawishta and ba zar Ki juz nikui ahl-i-karm nakhwahad mand."

Hafiz Ode, 176.

" Do thou, thyself, $O$ rich man console the poor who weep, Thy store of gold, thy silver heap shall not remain; 'Tis writ in golden letters upon the sapphire sphere,

'Save noble actions all things here shall not remain."

“ Tawangaranra waqf ast wa nazr wa mihmani

BiCKNELL.

Zakat wa itaq wa hadi wa qurbani

Tu kai badaulat-i-ishan rasi ki natawani

Juz in du rak'at wa an ham ba sad parishani." Gulistan, chap. 7 .

"Offerings to God, bequests to furnish ease

To the worn traveller, enfranchisement

Of slaves, alms, gifts and sacrifices, - these

Are rich men's works. Say, when wilt thou invent

Like merits for thyself who can'st but pray

With twice a hundred wanderings, twice a day?"

(EASTWICK).

"Tawangari ba hunar ast na ba mal, buzurgi ba aql ast na ba sal." GUListan, chap. I.

"Wealth consists in talent, not in goods ; greatness in understanding, not in age."

(EASTWICK).

\footnotetext{
"Tawan shinakht ba yak ruz dar shamail-i-mard

Ki ta kujash rasid ast paegah ulum

Wali za batinash aiman ma bash wa gharra mashu

Ki khubs-i-nafs na gardad ba salaha m'alum." Gulistan, chap. 8.

" From a man's qualities a day's enough

To make us of his learning's limits sure,

Plume not thyself as though the hidden stuff

Thou of his heart hast reached; nor be secure,

For not e'en long revolving years can tell

The foul things which in man unnoticed dwell."
} 
"Tawaz'u kun, ey dust ba khasm tund Ki narmi kunad tigh burranda kund."

Bostan of $\mathrm{S}^{\prime}$ ADI, chap. 4.

"Oh friend! exercise humility to a stern enemy,

For gentleness makes blunt the cutting sword."

(Cl ARKE).

"Tawaz'u kunad mardra sarfaraz

Tawaz'u buwad sarwaranra taraz."

Pandnama of $\mathrm{S}^{\mathrm{A}} \mathrm{Ad}$,

"Humility exalteth a man, Humility is the embroidery of chiefs." Gladwin.

“Ta za jahl wa khwanbaki wa fazul,

U ba pish-i-ma wa ma az wai malul

Tishna ra dard-i-sar arad bang r'aad,

Chu na danad k'u kushayad abr s'ad.

Bikhabar az zauq-i-ab-i-asman,

Chashma-i-u manadast dar jue rawan;

Markab-i-himmat su aflak rand

Az musabbib la jurm mahjub rand."

JALALUDDIN RUMi.

"Through ignorance, sloth and folly,

Though He stands by us, we are shut off from Him,

The noise of thunder makes the head of the thirsty ache,

When he knows not that it unlocks the blessed showers,

His eyes are fixed on the running stream

Unwitting of the sweetness of the rain from heaven ;

He urges the steed of his desire towards the caused,

And perforce remains shut off from the causer." (Whinfield).

" Ta zan na buri ki man bikhud maujudam

$\mathrm{Ya}$ in rah-i-khun khwara bakhud paimudam

In budi na bud-i-man za bud-i-u buwad

Man khud kih budam, kuja budam, kai budam?"

Omar Khayyam.

" Think not I am existent of myself,

Or walk this blood-stained pathway of myself ;

This being is not mine, it is of Him,

Pray what and where and whence is this myself?"

(Whinfield).

"Thalathat 'ihbabu; fahubbun 'ilaqatun, wa hubbun timlaiqun, wa hubbun huwa 'Iqatlu."

(ANON).

Three be the ways of love : a knitting of heart to heart ; a pleasing of and eyes; a third love whose name is death." C. J. Lyall.

Thamaratu 'ljubni la ribhun wa la khusrun." ARabic Proverb.

"The fruit of timidity is neither gain or loss." 
" Thumma qasat qulubukum min ba'di dhalika fahia k'alhijarati au ashaddu qaswatan wa'inna mina'l hijarati lama yatafajjaru min hu 'lanharu wa inna minha yashshaqqaqu fa yakhraju minhu'lma'u wa inna minha yahbitu min khashiyati 'llahi."

KORAN, chap. 2.

"Then after that ycur hearts became hard, and they were like rocks or harder still ; for verily there are rocks from which rivers have gushed, and there are others verily from which when cleft, water hath issued, and there are others verily which have sunk down through fear of God."

(RODWELL).

“ Tifl ta gir wa ta poya na buwad

Markabash juz gardan-i-baba na buwad,

Chun fazull gasht wa dast wa pa namud

Dar fana uftad, dar kur wa kabud."

Jalaluddin Rumi,

"So long as a babe cannot grasp or run,

It takes its father's back for its carriage,

But when it becomes independent and uses its hands

It falls into grievous troubles and disgrace." Whineield.

"Tigh dadan dar kaf-i-zange mast

Bih ki ayad ilmra nakas ba dast."

JaLALUdDin RUmi.

"Better to arm a drunken negro than

To lavish learning on a wicked man." - (EAstrwick).

"Tigh dar dastash nih az ujuzash bikun

Ta ki ghazi gardad u ya rahzan,

Z'anki 'karamna' shud Adam z'ikhtiyar

Nim zambur 'asl shud, nim mar."

Jalaluddin Rum.

"Place a sword in his hand and remove his impotence

To see if he turns out a warrior or a robber;

Because freewill is that with which 'We honour Adam,'

Half the swarm beconie bees, and half wasps."

(WHINHIELI)).

“ Tigh-i-hllm az tigh ahan tiztar

Bal za sad lashkar zafar angiztar."

ANWAR-1.SUHEILI.

"Mildness than steel a greater sharpness boasts, Yea, 'tis more conquering than a hundred hosts."

EASTwtck.

"Tigh-ra chun ba qasd-i-jar kardand

Rast chun surat-i-zaban kardand."

ANWAR-1-Streill.

"Since swords were formed a deadly trade to ply,

'Twas right them in the shape of tongues to make."

EAsTWICK. 
"Tihi pae raftan bih az kafash tang

Bala'e safar bih ki dar khana jang;

Bazindan-i-qazi giriftar bih

Ki dar khana didan bar abru girih."

Bostan of S'ADI, chap. 7.

" To go barefoot is better than the tight shoe,

The toil of travel better than contention in the house;

To be a captive in the Qazi's dungeon is better

Than in the house to see contraction on the eyebrow of the wife."

“ Tire ki ajal kashad siparha hich ast

(Clarke).

Wa in muhtashime wa sim wa zarha hich ast,

Chandanki barue karha nigaram

Nikast ki nikast digarha hich ast."

(OMAR KhaYyam).

" Against death's arrows what are bucklers worth?

What all the pomps and riches of the earth?

When I survey the world I see no good

But goodness, all beside is nothing worth." (WHINFIELD).

" Tirkash umarash tihi shud, umar raft

Az dawidan dar shikar-i-saya tuft

Saya'e yazdan chi bashad daya'e ash

Wa rihanad az khiyal wa saya'e ash

Saya'e yazdan buwad banda'e khuda

Murda'e in 'alam wa zinda'e khuda."

Jalailudin Rumi.

" Our life's our quiver. When our years are vainly spent

In chasing phantoms, grief one day will have its vent.

Let God's protection mercifully on us rest,

All fancies and all phantoms stand at once confessed,

God's servants are IIis shadows bere below on earth

To this world dead, but living in a second birth." REDHouse.

"Tishnaganra numayad andar khwab

Hama alam ba chashm chashma'e ab."

Gulistan, chap. 7.

"To those athirst the whole world seems

A spring of water in their dreams."

(EASTWICK).

"Tu an gah shawi pish-i-mardam 'aziz

Ki mar khwishtan ra na giri bachiz

Buzurge ki khud ra za khurdan shumard,

Badunya wa 'uqba buzurgi biburd."

Bustan of S'ADI, chap. 4.

"Thou becomest precious before men at that time

When thou reckonest thyself for nothing,

The great one who reckoned himself among the small folk,

Carried away greatness in this and in the future world."

(Clarke). 
- Tu'asi 'nnasiha 'lbarra wa ta'tasu wa tazwarru

Wa tanqadu liman gharra, wa man mana wa man namma Wa tasa' $f$ hawa 'nnafsi, wa tahtalu ala 'lfalsi

Wa tansa dhulmata 'rramsi wa la tadhkuru ma thamma."

MaQa.hat of Hariri, chap. ix.

"Thou resistest him who counselleth righteousness; thou art hard in understanding; thou swervest aside; but thou followest the guiding of him who deceiveth, who lieth, who defaneth. Thou walkest in the desire of thy soul ; thou schemest after money but thou forgettest the darkness of the grave, and rememberest not what is there."

(Chenery).

"Tu auwwal na basti, chu sar-i-chashma bud ;

Chu sailab shud, pish bastan chi sud." Bostan of S'ADl, chap. 7.

"At first when it was a mere fountain, thou didst not bind it, When it became a torrent, of what use is binding?" (CLARKE).

" Tu az an ruze ki dar hast amadi

Atishi ya khak ya bade budi ;

Gar bad an halat tura budi beqa

Kai rasidi mar tura in irtiqa?"

Jal,aluddin Rumi.

"On the day that you entered upon existence

You were first fire, or earth, or air,

If you had continued in that your original state,

Ilow could you have arrived at this dignity of humanity."

WIINFIELD.

"Tu az changal gurgam dar rabudi

Chi didam? aqibat khud gurg budi."

ANWAR-I-SUHEILI.

" Thou didst me from the wolf's claws free; but now

I do at last perceive a wolf art thou:"

EASTWICK.

"Tu ba k'aba gar narafti, bikashandat sa'adat,

Maguriz, ey fuzuli ki za haqq mafarr na dari."

Diwan-1-Shams-1-TABRiz.

"If you have not gone to the Kaaba, fortune will draw you thither, Do not flee, O babbler, for you have no refuge from God."

“Tu barae wasl kardan amadi

(NICHOLSON).

$\mathrm{Na}$ barae fasl kardan amadi;

Ta tawani, pa ma nih andar flraq

Abghadha 'l'ashya "indahu 'ttalaq."

Jalaluddin Rum.

"Thou hast come to draw men to union with Me,

Not to drive them far away from Me,

So far as possible, engage not in dissevering ;

'The thing most repugnant to Me is divorce.',

(WHINFIELD). 
" Tu bar an guzida'e khuda wa paighambar Guzidi fulan wa fulan wa fulanra."

NASIR-I-KHUSRAW.

"God and His Prophet thus decreed; but, no!

You much prefer the views of So-and-so."

E. G. BROWNE.

"Tu baz-i-said-i-shahi b'ustukhwan m'angar Huma'e himmat-i-khudra buland rah parwaz." AKHLAQ-I-MuHsins.

"Thou, the falcon of the royal wrist, look not upon bones, Give a lofty flight to the phonix of thy ambition." (KEENE).

"Tu budi awwal, wa akhir tu bashi Tu bih kun akhiram az awwalinam; Chu tu pinhan shawi az ahl-i-kufaram, Chu tu paida shawi az ahl-i-dinam."

Diwan-I-Shams-I-TABRIZ.

"Thou wert first and last thou shalt be, Make my last better than my first, When Thou art hidden, I am of the infidels, When Thou art manifest, I am of the faithful."

(NICHOLSON).

“Tu dar 'aqila'e tartib-i-rish wa dastari Chiguna ratal-i-giran khwarra ba dast ari."

Diwan-I-Shams-I-Tabriz.

"You are in the bonds of (absorbed in) the arrangement of beard and turban,

How will you gain him who quaffs the mighty flagon (of love)?"

(NICHOLSON).

" Tu, ey bulbul, ki ba gul dar wisali

Ghanimat dan ki bas farkhanda fali."

ANWAR-I-SuHeILI.

"O nightingale! that with the rose dost sit,

Thy state is blissful, therefore value it." EAsTwick.

"Tu gil budi wa dil shudi, jahil budi, aqil shudi

An k'u kashidat in chunin, an su kashanat an chunan

Andar kasha kashhae'u nushast nakhushhae'u

Ab ast atishhae'u, bar wai makun rura giran."

Diwan-I-Shams-I-TABriz.

"Thou wert dust and art spirit, thou wert ignorant and art wise,

He who has led thee thus far, will lead thee further also,

How pleasant are the pains He makes thee suffer while He gently draws thee to Himself,

His flames are as water, do not frown upon Him." (NICHolson). 
"Tu hama tam"a bar an nih kl bar an nist ummidat Ki za naummidi-i-awwal tu badin sue rasidi."

Diwan-I.SHaMS-I.TABRIZ.

"Set thy whole desire on that whereof thou hast no hope, For thou hast come thus far from original hopelessness."

" Tu ham bar dare hasti ummidwar

(Nicholson).

Pas ummld bar dar nishinan barar;

Nakhwahi kd bashad dilat dardmand,

Dil-i-dardmandan bar awar za band."

Bostan of S'Adi, chap. I.

"Thou even art hopeful at the door of God,

Then accomplish the hope of those sitting at thy door,

Thou dost not wish that thy heart may be sorrowful,

Bring forth from fetters the heart of the sorrowing ones."

“ Tu hamchu wadi khushki wa ma chu barani

(Clarke).

Tu hamchu shahr-i-kharabi wa ma chu mimari,

Baghair-1-khidmat-1-ma ki mashariq-1-shadist

Na did khalq wa na binad za shadi asari." Diwan-i-Shams-i-Tabriz.

"You are as a dry valley and $I$ as the rain,

You are as a ruined city and $I$ as the architect,

Except my service which is joy's sunrise

Man has never felt and never will feel an impression of joy."

"Tu ham gardan az hukm-1-dawar ma pich Ki gardan na pichad za hukm-i-tu hich."

(NICHOLSON).

" Do thou also from the order of the Ruler (God) twist not thy neck, So that no-one from thy order may twist his neck." (CLARKE).

“Tu k'az khwab-i-naushin babang-1-rahil

Nakhizi, digar kai rasi dar sabil?

Sabaq burda rah-rau, ki barkhast zud,

Pas az nagl bedar budan, chi sud?"

Bostan of S'ADI, chap, 9.

"When from sweet sleep at the sound of 'Alrahil' (march !) thou

Risest not, when wilt thou again reach the track of the caravan?

That wayfarer excelled, who rose quickly,

To be awake after translation to the next world what profit is it ?"

“Tu k'az sara'e tabl'at nami-ravi birun,

(CLARKE).

Kuja bakui-haqiqat guzar tawani kard?

Gada'i dar mai-khana tarfa lksirast,

Gar in 'amal bikuni, khak zar tawani kard."

HAFIZ ODE, 125.

"Thou who ne'er hast issued from the shrine of sense,

How to Truth's high pathway can'st thou journey hence?

Begging at the wine house is the chemic stone,

Dust to gold transmute thou by this act alone." BickNell. 
"Tukhm-i-daghl mikashti, afsusha mi-dashti

Haqq-ra 'adam pindashti, aknun bibin ey qaltaban!"

DiWAN-I-ShaMS-I-TABRIZ.

"Thou didst sow the seed of deceit, thou didst indulge in derision,

Thou didst regard God as nothing : see now, O miscreant !"

"Tukhm-i-takabbur m'afshan sinara

(NichOLSON).

Jae madih dar dil-i-khud kinara."

Awwar-I-Suheili.

" Sow not the seeds of pride within thy breast,

Nor suffer malice in thy heart to rest." "EASTwick.

"Tu murgh-i-'alam-i-qudsi, nadim-i-majlis-i-unsi

Darigh bashad agar tu darin maqam bamani

Hamirasad za samawat har sabah nidayat

Ki rah buri banishana, chu gard-i-rah binshani,

Barah-i-k'aba'e waslash bibin bar har bun-i-khari

Hazar kushta'e shauqand dada jan ba jawani

Hazar khasta dar in rah faru shudand wa niyamad,

Za bui wasl nasime, za kui dust nishani." Drwan-I-Shams-I-TABriz.

" $O$ honoured guest in love's high feast, $O$ bird of the angel sphere,

'Tis cause to weep if thou wilt keep thy habitation here.

A voice at morn to thee is borne-God whispers to the soul,

'If on the way the dust thou'llt lay, thou soon wilt gain the goal,

That road be thine toward the shrine; and lo! in bush and briar

The many slain by love and pain in flower of young desire,

Who on the track fell wounded back and saw not ere the end

A ray of bliss, a touch, a kiss, a token of the Friend."

"Tu na karda bar khalq bakhshaishe

(NICHOLSON).

Kuja yabi az khwish asaishe,

Chu dilha za bimat binaland hame

Ki bar jan-i-rishat nihad marhame?"

ANWAR-I-SUHEILI.

" Thou, who didst ne'er to others pardon grant,

When wilt thou solace for thine own self find?

And say, when all in terror of thee pant,

Who will spread ointment on thy wounded mind?"

“Tu niku rawish bash ta bad sigal

EASTWICK.

Ba bad guftan-i-tu nayabad majal

Chu ahang-i-barbat buwad mustaqim

Kai az dast-i-mutrib khurad gushmal."

Gulistan, chap. 2.

" Walk well, that he who would calumniate

Thee may naught evil find of which to prate ;

For, when the lute a faithful sound returns,

It from the minstrel's hand what censure earns."

(EASTWICK). 
"Tu nik wa bad ham az khud bipurs,

Chira digare bayadat muhtasib?

Wa man yattaqi 'llaha, yuj'il lahu

Wa yarzuqhu min haithu la yahtasib."

HAF12.

" Learn good and evil from thyself alone,

A watchman wherefore in some other own?

' God helps the creature that Him glorifies,

And, whence he hopes not all his wants supplies."

" Tura janat nama ast, kardar khatt

(BICKNELI.).

Ba jan bar makun juz ba niki raqam

Ba nama dirun jumla niki nawis

Ki dar dast-1-tust ey biradar qaiam."

NASIR-1-KhUSRAw.

"Thy soul is a book, thy deeds are like the writing : write not on thy soul ought else but a fair inscription,

Write what is wholly good in the book, O brother, for the pen is in thine own hand."

E. G. Browne.

" Tura ki dard na bashad za hal-i-ma chi tafawut,

Tu qadr-j-tishna chi dani, ki dar kinara'e jau'i?" ANwar-I-Suheilt.

"How canst thou, painless, estimate the cruel pang of our regret?

How tell what those athirst must feel, while by thee flows the rivulet."

"Tu pak bash, wa madar, ey biradar az kas bak, Zanand jama'e napak gazuran bar sang."

EAsTwick.

Gulistian, chap. I.

"Remain thou pure $O$ brother and have no fear of anyone :

It is the unclean garment which the washerman dashes against the stone."

(PlatTs).

"Tura nist an takiya ba kardigar

Ki mamluk ra ba khudawandgar."

Bostan of S'ADI, chap. 6.

"Thou hast not the same reliance on the Omnipotent, That a slave has on his Lord."

"Tura ta dihan bashad az hirs baz

Niayad bigush-i-dil az ghaib raz."

BostaN OF S'ADI, chap. 3 .

"So long as thy mouth is open through avarice,

The secret of God from the hidden comes not to the ear of the heart."

(CIARKE).

“ Tura zi kungara-1-'arsh mi-zanand safir

Na-danamat ki darin khakdan chi uftadast."

HAFiz.

"They are calling to thee from the pinnacles of the throne of God, I know not what hath befallen thee in this dust heap."

(E. G. Browne). 
"Tu rihai ju za na jinsan ba jadd Suhbat-i-najins gur ast wa lahad."

Jalialludin RUMi.

"Seek earnestly for deliverance from the uncongenial, The society of the uncongenial is like the grave."

"Tute kalaghash bud ham nafas Ghanimat shumarad khulas az qafas."

BostAN OF $\mathrm{S}^{\prime} \mathrm{ADI}$

"A parrot for whom a crow was companion Considers freedom from the cage, gain.".

(Clarke).

“Tutian wa bulbulanra az pasand

Az khush awazi qafs dar mikunand Zaghra wa chaghdra andar qafs

Kai kunad, in khud nayamad dar qisas." JaLALUdDIN Rum.

"It is on account of their sweet voices

That choice parrots and nightingales are prisoned in cages ;

Ugly owls and crows are never prisoned in cages,

Such a thing was never heard of in history."

(WhINFIELD).

“ Tu tu ham me kuni az qurb Haqq

Ki tabqgar dur na bud az tabq

An na me bini ki qurb auliya

Sad karamat darad wa kar wa kiya?

Ahan az Daud mum me shawad

Mum dar dastat chu ahan meshawad."

JALALUDDIN RUMi.

"Thou fanciest thyself near to God, Saying 'The maker of the dish is not far from the dish,' Knowest thou not that the nearness of saints to God. Involves the power to do mighty works and signs? Iron was as wax in the hands of David, Wax in thy hands is as iron."

(WHINFIELD).

“ Tu u mulk u ja Sikandari, man u rasm u rah qalandari Agar an khush ast, tu dar khuri, wa gar in bad ast mara saza."

KURRAT AL AYN.

" Sikandar's pomp and display be thine, the Kalandar's habit and way be mine,

That, if it please thee, I resign, while this, though bad, is enough for me."

E. G. BRowne.

“ Tu yar-i-khilwat-i-nazi, muqim-i-parda'e razi, Qarargah chi sazi dar in nishiman-i-fani?

Ba hal-i-khud nazare kun, birun birau, safare kun, Za habs-i-'alam-i-surat bamarghzar-i-ma'ni."

Diwan-I-Shams-I-TABriz. 
"Thou art a darling bosom friend, thou art always belind the secret veil, Why dost thou make thy dwelling-place in this perishable abode, Regard thine own state, go forth and journey From the prison of the Formal world to the meadow of Ideas.".

(Nicholson).

" Tu zar na'i, ey ghafli-i-nadan, ki tura

Dar khak nihand, wa baz birun awarand."

Omar Kilayyam.

"You are not gold; once hidden in the earth

No-one will care to dig you up again." WhiNfiELD.

" Uallilu 'nnafsa bi 'l'amall 'arqubuha

Ma 'adhyaqa 'l'aisha lau la fashatu 'I'amall ;

Lam 'artadhi 'l'aisha wa'laiyyamu muqbilatun

Fakaifa 'ardha waqad wallat 'ala '1'ajali ?"

Al. Tughral.

" But midst my sorrows and iny toils

Hope ever soothed my breast with smiles,

IIer hand removed each gathering ill,

And oped life's closing prospects still.

Yet spite of all her friendly art

The spacious scene ne'er gained my heart;

I loved it not although the day

Met my approach and cheered my way,

I loathe it now the hours retreat

And fly me with reverted feet." J. D. Carlyle.

" Uallimuhu 'rrimayata kulla yaumin,

Fallama ashtadda sa'iduhu, ramani."

GULISTAN, chap. r.

"I taught him archery every day,

And when his arm waxed strong, he shot me." (Platts).

" $U$ ba juyanda-i-khud hamrah ast, wa dast girifta dar talab-ikhud mitazad."

Jami, Beharistan.

"He is the companion of the journey of then who seck Him, and holds by the hand those who are in search of Ilim." (ASIATIC JOURNAL).

" U ba khunam tishna wa man bar labash; ta chun shawad kam bistanam $a z u$, ya dad bistanad zi man."

HaFiz.

"Thirsty for my blood-He, and for His lip-I. So that when it happeneth,

My desire I will take from Him, or revenge He will take from me."

" U bifarmudast man in bandagi

(CLAKKE).

Nist mara az khud in guyandagi,

Jan barae amr-i-u darim ma

Gar bar rege guyad u, karim ma."

Jalaluddin Rumi。 
"God has enjoined this servitude upon us,

We say not this merely on our own authority;

We enjoy life on condition of doing His will;

If $\mathrm{He}$ bids us, we sow our seed upon the sand."

“ U chu Faraun wa tanash Musa'e u

WHINFIELD.

U ba birun mi-dawad ki ' $k$ ' $u$ adu?'

Nafs andar khana'e tan naznin

Bar digar kas dast mi-khayad ba kin."

JALALUDDIN RUMI.

"He is like Pharaoh and his body like Moses,

He runs abroad crying 'Where is my foe?'

While lust is in his house, which is his body,

He bites his finger in spite against strangers."

“ Udimu mitala 'lju'i hatta umitahu

WHINFIELID.

Wa 'adhrabu 'anu 'dhdhikra safhan fa 'adhhalu

Wa 'astaffu turba 'lardhi kaila yara lahu

Alayya mina 'ttawali amraun mutatawwilu."

Ash Shanfara.

"I make perpetual the term of delay for the satisfaction of the calls of hunger, unt!l I kill it. I then turn away from noticing it, and I forget it.

"And I lick up the dry dust of the earth, lest some pretender to generosity should imagine in himself a superiority over me by offering food."

REDHOUSE.

" Udkhul fi "ibadi multaqi

Jannatan min ruyati ya muttaqi."

JALALUDDIN RUM.

" Enter the hearts of my servants

To gain the paradise of beholding me, O fearer of God."

" Udkhulu 'labyata min abwabaha

W'utlubu laghraz fl asbabiha."

WHINFIELD.

JALALUDDIN RUMI.

" Enter houses by the doors

And trace effects to their causes."

"Uffa li ddunya idha kanat kadha

Ana fiha fl bala'in wa adha

In safa 'aishu amrin fl subhiha

Jarr'athu mumsiyan kasa 'rradda

Wa laqad kuntu idha ma qila man

An 'amu 'l'alami 'aishan qila dha."

Alif Laila wa Laila.

"Foul fall thee, world it should be so!

Nought else but toil and wail and woe

Is doled to me.

"In morning tide though life be bright,

Yet man must drain the cup ere night

Of misery.

"And e'en with me if men asked erst

'Who in the world of joy ranks first ?'

They answered 'He!'"

TORRENS. 
"From the reflection of the ruddy crepuscule the horizon taketh the hue of the rose-garden."

ClaRKE.

\section{"U jahan kamil ast wa mufrad ast}

Nuskha'e kull wujud ura ba dast

Pas haml-guyand har naqsh wa nigar

"Muzhda ! muzhda! nak hami-ayad bahar!'" JALALUdDIN Rusi.

" $\mathrm{He}$ is the perfect world, yet $\mathrm{He}$ is single,

He holds in hand the writing of the whole of existence,

Wherefore all forms and colours of beauty cry out,

'Good news! good news! lo! the spring is at hand!"'

WHINFIELD.

" U ki ghafll bud az kisht bahar

U chi danad qimat-i-in ruzgar

Dar panah lutf-i-haqq bayad gurikht

K'u hazaran lutf bar arwah rikht

Ta pinahe yabi anki chun panah

Ab wa atish mar tu ra gardad sipah."

JALALUDDIN RUMI.

"Whoever may put off to sow seed in spring Ignores the true value of time's swiftest wing, Let each one take refuge in mercy of God

Who grace manifold on our souls has bestowed, Then shalt thou find shelter, when shelter thou needest, Fire's, water's protection thou'lt have as thou heedest."

Redhouse.

"Ukhtar watanan ma ardhaka fa'inna 'lhurra yadhi" $f$ baladihi wa la y'urafu qadruhu."

SHERISH.

"Choose a land which pleases thee, for the free man is neglected in his own country and his worth is not recognised."

" Ulamara zar bidih ta digar bikhanand wa zuhhadra chize ma dih ta zahid bamanand."

GUlistan, chap. 2.

"To the wise give gold that they may study the more; and to the devout give nothing that they may remain devout." (EASTwICK).

" Umar barf ast wa aftab tammuz

Andake manad wa khwaja gharra hanuz." Gulistan, Preface.

" Life is like snow in July's sun

Little remains; and is there one

To boast himself and vaunt thereon?" EASTwick. 
“ Umaraha shud ta dar in kakh-i-kuhan

Tar-i-nazm basta bar 'ud-i-sukhan,

Har zaman az nau nawa'e mi-zanam

Dam za diri majara mi-zanam

Raft umr, wa in nawa akhir na shud

Kast jan wa in majara akhir na shud

Pusht-i-man chu chang kham gasht hanuz

Har shabe dar sar "udam ta ba ruz." Jami (Salaman and Absal.).

"And yet how long, Jami, in this old house

Stringing thy pearls upon a harp of song?

Year after year striking up some new song

The breath of some old story. Life is gone

And yet the song is not the last; my soul

Is spent, - and still a story to be told !

And I whose back is crookéd as the harp

I still keep tuning through the night till day."

Fitzgerald.

" Umar biguzasht ba bihasili wa bu 'lhawas1

Ey pisar jam-i-mayam dih ki bapiri birasi

Dush dar khail-i-ghulaman-i-darash mi-raftam

Guft ' $k$ 'ey bekas bichara, tu bari chi kasi?

Ta chu mijmar nafsi daman-i-janan girim

Dil nihadim bar atish zl pae khush nafsi.'"

HAFIZ.

"In fruitlessness and lustfulness passed my life,

$\mathrm{O}$ son! give me the cup of wine so that to old age thou mayest reach,

Last night in the crowd of slaves of His door I went,

He spake, saying, ' $O$ friendless, remediless one, the load of what person art thou,

So that like the censer a moment we may take the skirt of the Beloved,

We placed our heart on the fire for the sake of a pleasant breath."

Clarke.

“ Umar ba khushnudl dilha guzar

Ta za tu khushnud shawad kirdagar."

Nizams.

"Pass thy life in contenting hearts that the Creator may be content with thee." Asiatic Miscellany.

" Umar dar kunj-i-tajarrud magzaran digar ki hast

"Ishrat abad tahhul rauza'e aman wa aman." ANwar-I-Suheil..

"Pass not thy life a celibate, the while

Thou mightest, bird-like, those glad gardens skim,

Where pleasures reign and joys the goblet brim."

EASTIVICK.

" Umar ki bi ishq raft hich hisabash ma gir

Ab-i-hayat ast ishq dar dil wa janash pazir."

Diwan-1-Shams-I-TABriz. 
"Prize not at all life that has passed without love, Love is the water of life: receive it in thy heart and soul."

NichOLSON.

" Umaththllu shakhsahum fl wasti qalbi

Gharamun wa ishtiyaqun wa iftikaru

Eya man dhikruhum adha dithari

Kama hubba lahum hauli shi'aru

Ahibbtuna lla kam dha 'ttamadi

Wa kam hadha 'ttaba 'udu wa 'nnafaru." Alif Lalla wa Laila.

"Their form lies pictured in my bosom's core

With love desire and dreamy passion fraught,

Close as a vest their memory still I wore

While love enwrapped me in a rube of thought,

Long as they linger hence, so lastingly

Endures our love, past mortal constancy." TORrens.

" Ummatu 'l'ishqi khafl fl 'l'ummum

Mithl jud haulahu laumu sagam."

Jalalludin Rum.

"The people of love are hidden among the peoples

As a liberal encompassed by the coniumely ol the base."

" Ummid-i-aflyat an gah buwad muaflq-i-aql

WHINFIRLD.

Ki nabz ra batabiat shinas binumal

Bipurs har chi na dani ki zill-i-pursidan

Dalil-i-rah-i-tu bashad ba-azz-i-danai."

GuListan, chap. 8.

"Hope thou with reason for good health when thou

Dost to the skilful leech thy pulse present,

Ask what thou knowest not, - with the stigma now

(If shame there be) of asking be content,

And thus in learning grow pre-eminent." EAstwick.

" Ummid basta bar amad wali chi faida az anki Ummid nist ki umr guzashta baz ayad."

Gulistan, chap. r.

" Hope long delayed is granted. Have I gained

Aught? Nay. Life spent returns not lack again."

" Ummid-i-dusti nau az dushmanan kuhan

EASTWICK.

Chunan buwad ki talab kardan gul az gulkhan." ANwar-I-SUHeIL

"To hope new friends will spring from ancient foes

Is from a furnace to expect a rose."

(EASTwICK).

" Ummidwar buwad admi ba khair-1-kasan

Mara ba khair-1-tu ummid nist,-sharr marasan."

GUl..sTA , chap. 4 .

"From some a man might favours hope, - from thee

We hope for nothing but immunity." EAsTwick. 
" Umri bi gul wa bada biraftim bigasht

Yak kar-i-man az daur-1-jahan rast nagasht

Az mai chu nashud hich murade hasil

Az har chi guzashtim guzashtim guzasht."

OMar Khayyam.

" Long time in wine and rose I took delight

But found my business never went aright ;

Since wine could not accomplish my desire,

I have abandoned and forsworn it quite."

(WHINFIELD).

"Umratan bad wa murad, ey saqian-i-bazm-i-Jam

Garchi jam-i-ma na shud pur mai badauran-i-shuma." Hafiz.

"O cup-bearers of the banquet of Jam-long be your life; that is our desire,

Although our cup be not full of wine at the circulation of the cup of yours."

(CLARKE).

" Umr-i-giranmaya dar in sarf shud

Ta chi khuram saif wa chi pusham sita,

Ey shikam khira binani bisaz

Ta nakuni pusht bakhidmat du ta."

Gulistan, chap. r.

" Life, precious life has been in pondering spent

On summer clothing and on winter food,

O glutton belly! let one loaf content

Thee, rather than the back in slavish mood

Be to the ground in other's service bent."

EASTWICK.

" Umr-i-tu chihal gasht, ba juz chihal na shudi

Dakhil ba dar madina'e dil na shudi

Guyand ki 'arbain buwad sal kamal

Shud umr-i-tu 'arbain wa kamal na shudi."

NABIL.

"Thine age is forty, yet thou art nought but a fool,

Thou hast not entered in at the gate of the city of the heart,

They say that forty is the year of perfection,

Thine age is forty, yet hast thou not become perfect."

E. G. Browne.

" 'Umr-i-tu chi du sad wa chi sisad, chi hazar

Z'in kukna sera birun birandat nachar

Gar badshahi war gar gada'e bazar

In har du ba yak nirk buwad akhir-i-kar."

Omar Khayyam.

"Though you should live to four or forty score,

Go hence you must as all have gone before ;

Then, be you king or heggar of the streets

They'll rate you all the same, no less, no more."

WHINFIELD. 
- Umri za pa'e murad za'i daram,

W'az daur-1-falak chist ki nafi daram,

Ba har ki blguftam ki tura dust shudam,

Shud dushman-i-man, wah $\mid$ kl chi tal' daram?"

Hariz.

" Crossed in my hopes in life, gone far have I,

From circling heaven but woes that mar have I ;

He whom at any time I called my friend

Has proved a foe to me; what star have I." BickNell.

" Umrur 'ala jadathi 'lladhi hallat bihi Umm-'al-Ala fanadiha lau tasm'au

'Anni halalti wa kunti jidda faruqatin baldan yamurru bihi 'shshuja'u fa'yafza'u?

Falaqad tarakti saghiratan marhumatan lam tadrina jaz'aun alaiki, fatahjaz'au,

Wa'idha sam'itu 'aninaha fl lailiha tafiqat 'alaiki shu'unu 'aini tadma'u."

Mcwallik Al-Mazmum.

"Take thou thy way by the grave wherein thy dear one lies, Umm-al-Ala, and lift up thy voice; ah, if she could hear ! How art thou come, - for very fearful wast thou,-to dwell In a land where not the most valiant goes but with quaking heart? And a little one hast thou left lehind-God's ruth on her! She knows not what to bewail thee means, yet weeps for thee. When her crying smites in the night upon my sleepless ears, Straightway mine eyes brimful are filled from the well of tears."

" Undhub zamanan salafa sawwadatta flhi 'ssuhafa

C. J. LYall.

Wa lam tazal mu'takifa ala 'lqabihi 'shshan'i."

"Bewail the time that passed away

Magamat of Hartri.

When thou hast blackened pages bright,

And never ceased to stcep thyself

In deeds of shame and heinousness."

STEINGaSS.

" Undhur bi ainika hal 'ardhun mu'attalatun Mina 'nnabati k'ardhin haffaha 'shshajaru Fa'addi 'amma yushiru 'laghbiyau bihi

Fa "eyyu fadhlin li udin ma lahu thamaru."

Maquatit of Hariki, chap. 37.

"See for thyself if a land that is not decked out with plants is like a land all around hedged in with trees rich of growth.

"So wen!l aside from what fools are in their sloth pointing to, for say, what good can there be in wood that never lears fruit." Siteiscass.

" Uqaddimu ustadhi 'ala nafsi walidi

Wa'in nalani min walidi 'lfadhlu wa' sh sharaf

Fadhaka murabbi 'rruhi wa'rsuhu jauharu

Wa hadha murabbi ' 1 jismi wa' 1 ismu min sadaf." 
"I esteem my teacher higher than my father, From my father came to me grace and honour, But my teacher nurtured my spirit and the spirit is a pearl, While uny father nurtured my body which is but a shell."

"Uqba'e z'in s'abtar dar rah nist Ey khunuk an k'ash hasad hamrah nist In jasd khana'e hasad amad badan K'az hasad aluda gardad khandan."

Jalalludin RUM.

"No mountain-pass as this life's progress is so steep, Let envy not increase thy load; thou canst but creep, The flesh a hot-bed is of envy and of strife These soil the soil ; for envy's bane of mortal life."

REDHOUSE.

" U-ra khwahi za zan wa farzand bibur Mardana dar az khwish wa paiwand bibur, Har chiz ki hast band-i-rah ast tura Ba band chiguna rah rawi, band bibur."

Omar Khayyam.

"If you seek Him, abandon child and wife, Forsake and sever all these ties to life ; All these are bonds that check your upward course, Arise and cut these bonds as with a knife." Whinfield.

" 'Uridu bastata kaffin 'asta inu biha

'Ala qadha'i huquqin lil'ula qibali, Wa' ddahru yu'kisu 'amali wa yuqni 'uni Mina 'lghanimati b'ada 'lkaddi b'ilqafali."

AL Tughrai.

" But wealth I own engrossed each thought, There was a moment when I sought The glittering stores ambition claims To feed the wants his fancy frames ; But now 'tis past, - the changing day Has snatched my high-built hopes away, And bade this wish my labours close, Give me not riches but repose."

J. D. Carlyle.

“ Ushahidu man 'ahwa bighairi wasilatin Fayalhaquni sh'anun 'adhallu tariqa Yuwajjiju naran thumma yutf birashshatin Lidhalika tarani muhraqan wa ghariqa."

GUlistan, chap. 2.

"I behold IHim whom I love without a mediator And so I fall into such a state that I lose my way; He kindles a fire, then extinguishes it with a sprinkling, For this reason thou seest me burnt and drowned." PlatTs. 
- Ushtur amad in wujud khar khwar Mustafa zadi bar in ushtur sawar Ushtura tang gule bar pusht-i-tust K'az nasimash dar tu sad guizar rast Mail-i-tu sue mughilanast wa reg Ta ki gul chini za khar murda reg."

JalaludDIN RUMH

"Thorn-eating camel truly is this world of ours, Ahmed then came and mounted; him that camel bears. $\mathrm{O}$ camel, on thy back thou bear'st a vase of rose, On thee from thence have sprouted rose-buds as God knows, Thy tastes lead thee to camel-thorn and wastes of sand, To thee the thorn's a rose ; the wilderness, rich land.

"Ustad-1-mu'allim chu buwad kam azar Kharsak bazand kudakan dar bazar."

REDHOUSE.

Gulistan, chap. 7.

"When the schoolmaster gentle is and sweet, The boys will play at leap-frog in the street."

"Utlub ad'durra, akhi wasti 'ssadaf W'utlub al fann min arbabu 'lharf."

EASTWICK.

Jalalundin Rum.

" Seek the pearl, $O$ brother, in the shell, And seek for skill among the learned."

" Utlubni 'inda 'Iqulubi 'Imunkasarati w'alqubur 'ulmundrisati." HaDis-1-QuDs1.

"Seek Me in the broken hearts and by the crumbling tombs."

“ Utlubu 'l'ilma wa lau kana bi 'Sinf." SAYING OF MUHAMMAD.

"Seek learning though it be as far as China."

"Uzr-1-taqsir-1-khidmat awardam

Ki nadaram bita'at istizhar

'Asiyan az gunah tauba kunand

"Arifan az ibadat-i-istighfar."

Gulistan, chap. 2.

" Excuse for my faulty service do I bring,

For I have not the strength to serve Thee;

Sinners of their sins repent,

Those who hold communion with thee implore forgiveness for worship. ping."

(Platts).

" Uzr khwahi kun wa 'afu talab chu uftad

Rakhna dar qa'ida yari yaran qadim;

War niayad band an rakhna baguftar zaban

Dar imarat girish kush bikhisht zar wa sim."

Jami, Biharistan, chap. 3 .

* Muhammad. 
" Excuse thyself and beg pardon from thy friends,

When a breach arises in the foundation of amity among friends;

And if the breach cannot be repaired by word of speech,

Endeavour to build it up by employing bricks of gold and silver."

(REHATSEK).

“Wa'auha rabbuka ila 'nnahli 'ani 'ttakhidhi mina 'ljibali buyutan wa mina 'shshajarin wa mimma ya rishuna, thumma kuli min kulli 'thamarati fa'sluki subula rabbiki dhululan yakhruju min butuniha sharabun mukhtalifun 'alwanuhu flhi shifa linnasi."

KORAN, chap. 16.

"Thy Lord hath taught the bee 'Provide thee houses in the mountains and in the trees and in the hives which men build thee; feed moreover on every kind of fruit and walk the easy paths of thy Lord; from its belly cometh forth a fluid of varying hues which yieldeth medicine to man.".

(Rotwell).

"Wa 'bud rabbaka hatta yatiyaka 'lyaqin."

KORAN, chap. 15.

"Serve thy Lord till the certainty (death) overtake thee."

(RODWELL).

"Wa 'dhkur rabbaka fl nafsika tadharru'an wa khifatan wa duna 'ljahri min 'lqauli bi'l ghuduwwi wa 'l'asali." Koras, chap. 7.

"Think within thine own self on God with lowliness and with fear and without loud-spoken words at even and morn." (RODWELL).

"Wa gar bar jafa pisha bashitafti

Ki az dast-i-qahrash aman yafti?"

Bostan of S'ADI.

"If $\mathrm{He}$ (God) had hastened against one tyranny-practising

Who could have obtained safety from the hand of His violence?"

"Wagar na dida'e dil bar kushayad az himmat

Nazr ba sue ma'ala na mitawan afkand."

(ClARKE).

ANTAR.I-SUHFili.

"If the soul's vision ope not by emprise

The sight to lofty things can never rise." FAsTwick.

"Wagar sail-i-marg amad wa har du burd

Chi bar takht sultan, chi bar dasht gurd?"

Bostan of S'AdI, chap. 6 .

"If the torrent of death comes and takes both,

Whether the sultan on the throne; or the wanderer in the desert,

What difference?"”

(ClaRKE).

"Wagar tu pae na dari, safar guzin dar khwish

Chu kan-i-l'al pazra shu az shu'a asr;

Za khwishtan safare kun ba khwish, ey khwaja,

Ki az chunin safare gasht khak m'adan-i-zar."

Diwan-1-Shanis-1-TABRIz. 
"Though you have no fcet, choose to journey in yourself, Like the ruby-mine receive a print from the sunbeams, Make a journey out of self into self, $\mathrm{O}$ master, For by such a journey earth becomes a quarry of gold."

(Nicholson).

"Wa'ghdhudh min sautika inna 'ankara 'laswati lasautu 'lhamir."

KORAN, chap. $3^{\mathrm{r}}$.

"Lower thy voice; verily the least pleasing of voices is surely the voice of asses."

(RODWELL).

"Wa hia tajri bihim fl maujin ka'ljibali wa nada nuhun 'bnaha wa kana fl m'azilin, ya bunayya 'rkab ma'ana wa la takun ma'a 'lkafirin Qala s'aawi ila jabalin ya'simuni mina 'Ima'i qala la 'asima 'lyauma min amrt 'llahi 111 a man rahima, wa hala bainahuma lmauju fakana min 'lmughraqin."

KORAN, chap. $\mathrm{Ir}$.

"And the ark moved on with them amid waves like mountains, and Noah called to his son, for he was apart, 'Embark with us, O my child, and he not with the unbelievers.' He said, 'I will betake me to a mountain that shall secure me from the water.' IIe said, 'None shall be secure this day from the decree of God save him on whon He shall have mercy.' And a wave passed between them, and he was among the drowned."

(RODWELL).

"Wa huwa 'lqahiru fauga "ibadihi wa yursilu 'alaikum hafadhatan hatta Idha ja'i ahadakumu 'lmautu tawaffathu rusuluna wa hum la yufarritun."

KORAN, chap. 6 .

"And He is the supreme over His servants, and sendeth forth guardians who watch over you until, when death overtaketh any one of you, our messengers receive him and they fail not."

(RODWELL).

"Wa idha bushshira ahaduhum bi'luntha dhalla wajhuhu muswadan wa huwa kadhim, yatawara mina 'lqaumi min su ma bushshira bihi ayumsikuhu ala hunin 'am yadussuhu fl 'tturabi."

KORAN, chap. I6.

"When the birth of a daughter is announced to any one of them, dark shadows settle on his face, and he is sad; he hideth himself from the people because of the bad news : shall he keep it with disgrace or bury it in the dust?"

RODWELL.

"Wa'idha bushshira 'ahaduhum bima dharaba lirrahmani mathalan dhalla wajhuhu muswadan wa huwa kadhim 'awaman yunashsh 'u fl 'lhilyati wa huwa fl 'lkhisami ghairu mubin."

KORAN, chap. 43. 
"But when that* is announced to any one of them which he imputeth to the God of mercy, as His likeness, his face settleth into darkness and he is silent-sad.

1 i" And make they a female to be the offspring of God, one who is brought up among trinkets, and is contentious without reason?"

(RODWELL).

"Wa'idha ra'u tijaratan au lahwan 'nfadhdhu ilaiha wa tarakuka qa'iman, qul ma ind llahi khairun min 'llahwi wa mina 'ttljarati wa 'llahu khairu 'rraziqin."

Koran, chap. 62 .

9" But when they get a sight of merchandise or sport, they disperse after it, $\$$ and leave thee standing alone. Say 'God hath in reserve what is better than sport or merchandise. And God is the best of providers."

(RODWELL).

"Wa'idha sa'laka ibadi 'anni, fa'inni qaribun, ujibu da'wata 'ddai' "idha d'aani falyastajibu li walyuminu bi la'allahum yarshudun."

KORAN, chap. 2.

"And when My servants ask thee concerning Me, then verily will I be nigh unto them and will answer the cry of him that crieth, when he crieth unto $\mathrm{Me}$, but let them hearken unto Me and believe in Me. Haply they will proceed aright."

(RODWELL).

“ Wa jala's-suyulu 'ani 't-tululi ka' annaha

Zuburun tujiddu mutuna-ha aklamu-ha

Fa-wakaftu as'alu-ha: fa-keyfa su'aluna

Summan khawalida ma yabinu kalamu-ha." Mo'Allaka of Lebid.

" And the torrents have laid bare its traces, as though

'Twere a book of which a pen renews the characters,

And I stood questioning them : but how can we question

Dumb rocks, whose speech is not clear?" E. G. Browne.

"Wa lan tastati'yu 'an ta'dilu baina 'nnisa'i wa lau harastum fa la tamilu kulla 'l'maili."

KORAN, chap. 4 .

" Ye may not have it at all in your power to treat your wives with equal justice, even though you fain would do so; but yield not wholly to disinclination."

(RODWELL).

"Walaqad khalaqna 'linsana wa na'alimu ma tuwaswisu bihi nafsuhu wa nahna 'aqribu ilaihi min habli '1warid." KoRAN, chap. 50.

"But of old we created man : and we know what his soul whispereth within him, and we are closer to him than his neck-vein." (RoDwELL).

* The ancient Arabs called their goddesses "daughters of God." 
"Wa la tarkan lla 'ddahri, wa"in lana, wa'in sarra, Fatulfa kamanl 'ghtarra bl'af'aan tanfuthu 'ssamma, Wa khaflld min taraqika, fa inna 'Imauta laqika, Wa sarin fl taraqika, wa ma yankulu in hamma."

Magamat of Hariri (i1).

"Rely not on fortune though it be soft, though it be gay : for so shalt thou be found like one deceived by a viper that spitteth venom. And lower thyself from thy loftiness for death is meeting thee and reaching at thy collar ; and he is one who shrinketh not back when he hath purposed."

(Chenery).

"Wa la tabll basalatuhum w'in hum salu b'liharbi hinan b'ada hinin

Humu man'au hima 'Iwaqba bidharbin yuwillafu baina 'ashtati 'Imanuni."

ABU'L GHul.

"Their sternness abides unflagging though they be roasted Again and again in war's most flaming furnace.

They held with the sword al-Wakaba's guarded meadow

The sword from whose edge flew all death's shapes united."

C. J. Lyall.

"Wa la tudhi 'fursata 'ssururi fa ma tadri aiyauman ta'ishu 'am dara,

Wa'lam ba'anna 'almanuna j'a'llatun wa gad 'adarat ala 'lwara dara

W'aqsamat la tazalu qanisatan ma qarra 'asra 'lmahia wa ma dara

Fakaifa turja 'nnajata min sharakin lam yanju minhu Kisra wa la Dara."

MaqAMat OF HaRIRl, chap. 28.

" Miss thou no chance of enjoyment, for thou knowest not if thou live a day or if an age,

know thou that death is going round, and the moon-halves circle above all created beings,

Swearing that they will not cease chasing them as long as morn and even turn and return;

How then mayest thou hope to escape from a net from which neither Kisra escaped nor Dara."

(STEINGASS).

"Wa lau kanat ad-dunya 4rsa litulligat, wa lakinnaha umm yahabbaha waladuha 'ala 'l'uquq1 wa tasadhum 'ani 'draku 'lhuquq."

ABU'L ALA.

"Were the world a bride she would have been divorced ; but rather she is a mother who has nursed and whom her children love in spite of unkind. ness and albeit she defrauds them of their rights."

D. S. Margoliouth. 
"W'alfata liddhari wa 'dhdharu zu fununi, Wa'l'usru k'alyusri w'alghani k'al'udmi w'alhayyu lilmanuni.”

SULMII IBN RABIAH.

\section{" Man is set}

The prey of time and time is change;

Life strait or large, great store or nought, All's one to time, all men to death."

C. J. Lyall.

“Wa lillahi 'Imashriqu wa 'lmaghribu fa'aynama tuwallu fathumma wajhu 'llahi, 'inna 'llaha wasiun 'alim."

KorAn, chap. 2.

"The east and the west is God's; therefore whichever way ye turn, there is the face of God. Truly God is immense, knowing."

(RONIVELL).

"Wa lillahi yasjudu man fl 'ssamawati wa l'ardhi tauan wakarhan wa dhilaluhum bi 'lghuduwwi wa 'lasal."

KORAN, chap. I3.

"And unto God doth all in the heavens and on the earth bow down in worship willingly or by constraint: their very shadows also morn and even."

(RODWELL).

"Wa 'lladhina kafaru 'amaluhum kasarabin biqi'atin yahsabuhu 'dhdhamanu ma'an hatta idha jaa'hu lam yajidhu shaian wa wajada 'llaha 'indahu fawaffahu hisabahu w'allahu sari'u 'lhisab."

KORAN, chap. 24.

"But as to the infidels, their works are like the mirage in a level plain which the thirsty deemeth to be water, until when he cometh unto it, he findeth it nought, but findeth that God is with him; and $\mathrm{He}$ fully payeth him his account, for swift to take account is God.)" (RoDwell).

“ W'allahi, ma yaghfulu 'ddayyanu, wa la tuhmalu ya insanu, bal sayuwadhau laka 'Imizanu, wa kama tudinu tudan."

MaQAIIAT OF HaRiki, chap. 2I.

"By Allah, the Judge shall not be unregarding : thou shalt not be left at large, $O$ man: but the balance shall be set for thee, and as thou rewardest, thou shalt be rewarded."

"W'altandhur nafsun ma qaddamat li ghadin."

(CHENERY).

"Let every soul look well to what it sendeth on for the morrow."

(RODWEI.L).

\footnotetext{
"Waludh bi 'Imatabi 'amama 'ddhahabi fa man daqqa baba karimin fatah."

Maqamat of Hariri, iz.
}

"Take refuge in repentance beiore thy departure; for whoso knocks at the door of the merciful causes it to open."

(Chr.nery). 
"Wa ma 'adraka ma yaumu 'ddin, thumma ma 'adraka ma yaumu 'ddin, yauma la tamliku nafsun linafsin shai'an wa 'lamru yauma'idhin lillahi."

KORAN, chap. 82.

"What shall teach thee what the day of judgment is? Once more ; what shall teach thee what the day of judgment is? It is a day when one soul shall be powerless for another soul; and all on that day sliall be in the hands of God."

(RODWELL).

"Wa ma khalaqtu 'Ijinna wa 'I'insa illa ll ya'budun."

Koran, chap. $51.6,30$

"Noveover I have not created Djinn and men but that they should worship me."

(RODWELL).

"Wa ma mata minna sayyidun hatfa 'anfihi wa la tulla minna haithu kana qatilu

Tasilu 'ala haddi 'dhubati nufusuna wa laisat 'ala ghairi 'dhubati tasilu."

ABD-UL-MALIK.

"Their dies among us no lord a quiet death in his bed, and never is blood of us poured forth without vengeance: Our souls stream forth in a flood from the edge of the whetted swords; no otherwise than so doth our spirit leave its mansion."

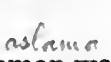

"Wa man 'ahsanu dinan mimman wajhahu lillahi muhsinun wa 'ttaba'a millat 'Ibrahima hanifan."

KORAN, chap. 4 .

"Who hath a better religion than he who resigneth himself to God and followeth the faith of Abraham the sound in faith?"

(RODWELL).

“Wa ma 'nnasu 'illa ka'ddiyari wa'hluha

Biha yauma halluha wa ghadwan balaq "iu."

LABID.

" And mankind are no other than the like of dwellings the occupants thereof being in them during the day in which they have alighted in them, ard to-morrow they are vacant."

(LANE).

"Waman 'a'radha "an dhikri fa'inna lahu ma'ishatan dhanka."

KorAx, chap. 20 .

"Whoso turneth away from My warning, his truly shall be a life of misery."

(RODWELL).

"Wa man talaba 'I ula min ghayri keddin

Adha'a l'amra fi talabi '1 muhall."

Arab Poet.

"And he who hopes to scale the heights without enduring pain, And toil and strife, but wastes his life in idle quest and vain."

E. G. Browne. 
"Wa man yattaqi 'llaha yaj'al lahu makhrajan wa yarzuqhu min haisu la yahtasib."

KORAN, chap. 65.

" And whoso feareth God, to him will He grant a prosperous issue and will provide for him whence he reckoneth not upon it." (RODWELL).

"Wamash madih an ki bi namaz ast

War khud dihanash za faqa baz ast ;

K'u farz-i-khuđa na mi guzarad

Az qarz-1-tu niz gham na darad."

Gulistan, chap. 8.

" Lend not to him, who prayer neglects, though he

Gasping with want and inanition be ;

For he who renders not to God His due,

What will he care for what he owes to you?" (EAstwick).

“Wa min ayatihi 'annaka tara 'l'ardha khashi'atan fa'idha 'anzalna alaiha 'Ima'i 'htazzat warabat, inna 'lladhi 'ahyaha lamuhi 'Imauta."

KORAN, chap. 4I.

"And among His signs is this that thou seest the earth drooping; but when we send down the rain upon it, it is stirred and swelleth; verily $\mathrm{He}$ who giveth it life, will surely give life to the dead." RoDwELL.

"Wa min ayatihi 'ljawari fl 'lbahri k'ala'lami 'in yasha' yuskini 'Iriyyha fayadhlalna rawakida ala dharihi."

KORAN, chap. 42.

"Among His signs also are ships out at sea like mountains; if such be His will, He lulleth the wind and they lie motionless on the back of the waves."

(RODWELL).

"Wa min b'adu fa la budda, mina 'l'ardhi idha 'utudda,

Siratun jisruhu mudda ala 'nnari liman 'amma;

Fakam min murshiddin dhalla, wa min dhi 'idhdhatin dhalla,

Wa kam min 'alimin zalla, wa qala ' 'lkhatbu qad tamma.'

Fabadir eyyuha 'lghumru lima yahlu bihi 'lmurru,

Faqad kada yahi 'lumru wa ma 'aql'ata 'an dhamma."

MaqAMat OF HaRiri (II).

" Afterward there is no escape from that review of souls; since Sirat is prepared; its bridge is stretched over the fire to every one who cometh thither. And how many a guide shall go astray! and how many a great one shall be vile, and how many a learned one shall slip and say, "The business surpasseth !' Therefore hasten $O$ simple one to that by which the bitter is made sweet; for thy life is now near to decay, and thou hast not withdrawn thyself from blame."

Chenery.

"Wa naza'na ma fi sudurihim min ghillin, tajri min tahtihim 'lanharu, wa qalu 'lhamdu lillahi 'lladhi hadana lihadha, wa ma kunna linahtadiya, laula 'an hadana." 
"And we will remove whatever rancour was in their bosoms, rivers shall roll at their feet : and they shall say "Praise be to God who hath guided us hither. We had not been guided, had not God guided us."

(RODWEL.L).

"W'andubi f'ilaki 'lqabiha wa sahbi lahi bidam

W'adbughihi bitaubatin qabla 'an yahlama 'al'adam

Fa 'asa 'llahu 'an yaqiki ss'aira 'lladhl 'htadam.

Yauma la 'athratun tuqal wa la yanfa'u 'ssadam."

MaQAMat of HaRiri (3r).

"Bewail thy work of shame shedding tears of blood for it,

Curing it with sore repentance, before the hide all through is rotten, May then be that Allah guard thee against the fire that blazes fiercely, On the day when sin is cancelled no more, tardy repentance vain."

(S'reingaSs).

“Waqaffaina bi 'Isa 'bni Maryama wa'atenahu 'l'Injtla waja'alna fl qulubi 'lladhina 'ttab'uhu ra'fatan wa rahmatan, wa rabbaniyatan 'btada'uha."

Koran, chap. 57 .

" We caused Jesus the son of Mary to follow them, and we gave him the Evangel, and we put into the hearts of those who followed him kindness and compassion, but as to the monastic life, they invented it themselves."

(RODWE1.1.).

"Waqt-1-zarurat chu namanad guriz

Dast bigirad sar-1-shamshir-1-tiz."

Gulistan, chap. x.

"The hand when flight remains not, in despair

Will grasp the edge of the sharp scimetar." (EAsTwick).

"Wa rakibatun niyaqan $\mathrm{fl}$ hawadijaha

Lam yaltafitna ila man ghasa fl 'lkuthubi." Gulistan, chap. 7.

"Borne aloft in camel-litters, what I pray do women care

For the tired pilgrim struggling through the sand-heaps drifted there?'

(EASTWICK).

"War aftab na rafti ba par wa pa har shab

Jahan chiguna munawwar ba gah sahar?

War ab-i-talkh na rafti za babr sue ufuq

Kuja hayat-1-gulistan shudi ba sall wa matar?"

Diwan-1-Shams-1-Tabriz.

"If the sun did not fare by foot and wing every night,

How would the world be illuminated at morning tide?

And if the salt water did not go up from the sea to the sky

Whence would the garden be quickened by river and rain?"

(Nicholson). 
“Wa'shshamsi wa dhuhaha, wa'lqamari idha talaha, wa'nnahari idha jallaha, wa'llail 'idha yaghshaha wa' ssamai wa ma banaha, wa'l'ardhi wa ma tahaha wa nafsin wa ma sawwaha fa'lhamaha fujuraha wa taqwaha, qad 'afiaha man zakkaha, wa qad khaba man dassaha."

Koran, chap. 9x. 1-10

"By the sun and his noon-day brightness, by the moon when she followeth him, by the day when it revealeth his glory, by the night when it enshroudeth him, by the heaven and IIim who built it, by the earth and Him who spread it forth, by the soul and Him who balanced it, and breathed into it its wickedness and its piety, -happy is he who hath kept it pure, and undone is he who hath corrupted it."

(RODWELL).

"Wasle ki dar an malal bashad

Hijran bih az an wisal bashad."

Anwar-1-Suheill.

" Sure separation would l)e better far

Than meetings which the cause of sorrow are."

EASTWICK.

"Watarahum yandhuruna a'ilaika, wa hum la yubsirun."

KORAN, chap. 7 .

"Thou seest them look towards thee, yet do they not see."

(RODWELI.).

"Wa 'ttaqu yauman la tajzi nafsun 'an nafsin shai 'an wa la yuqbalu minha "adlun wa la tanfa'uha shafa'atun." Koras, chap. 2.

"And dread the day when not in aught shall soul satisfy for soul, nor shall any ransom be taken from it nor shall any intercession avail."

(RODWELL).

"Wa 'tturi, wa kitabin mastur, fl raqqin manshur, w'albaiti 'lma"mur wa' ssaqf 'lmarfu' wa 'lbahri 'lmasjur, inna 'ađhaba rabbika lawaqi"."

KoRAN, chap. 52.

"By the mountain, and by the book written on an outspread scroll, and by the frequented fane, and by heaven's lofty roof, and by the swollen sea, verily a chastisement from thy Lord is most imminent." (RODwELL).

"Wawassaina 'linsana biwalidaihi, hamalathu ummuhu wahnan ala wahnin wa flsaluhu fi 'amaini 'ani 'shkur li walwalidaika ilaiyya 'Imasir."

KORAN, chap. 3i'.

"We have commanded man concerning his parents. (His mother carrieth him with weakness upon wcakness; nor until two years is he weaned.) "Be grateful to Me and to thy parents. Unto Me shall all come." (RodwelL).

"Wa-wujuhin yauma'izin nazirah ila rabbiha nazirah, wa-wujuhin yauma 'izin basirah, tazannu an yuf'ala bi-ha faqirah." 
"On this day shall faces beam with light, out-looking towards their Lord; and faces on that day shall be dismal, as if they thought that some calamity would therein befall them."

(RODWELL).

"Wayad'u 'l'insanu bi'shsharri du'ahu bi'lkhairt wa kana 'linsanu "ajulan."

KORAN, chap. 17 .

"Man prayeth for evil as if he were praying for good; for man is hasty."

(RODWELL).

“Wa yasalunaka ani 'ljibali, faqul yansifuha rabbi nasfan fayadharuha qa'an safsafan, la tara tha "iwajan wa la 'amtan, yaumaidhin yattabi'una 'dda'1 la iwaja lahu wa khasha'ati 'l'aswatu lirrahmani fala tasma'u illa hamsan."

KORAN, chap. 20.

"And they will ask thee of the mountains: Say then 'scattering my Lord will scatter them in dust; and He will leave them a level plain; thou wilt see in them no hollows or jutting hills. On that day shall men foliow the Summoner, - he marcheth straight on; and low shall be their voices before the Merciful ; nor shalt thou hear aught but the light footfall."

(RODWELL).

“Wa yauma yuhsharu 'a'daau 'llahi ila 'nnari fahum yuzaun, hatta idha ma jauha shahida alaihim sam'uhum wa 'absaruhum wa jaluduhum bima kanu ya'malun wa qalu li juludihim lima shahidthum alaina, qalu antaqana 'llahu 'lladhi 'antaqa kulla shaian."

Koran, chap. 4 I.

"And one day the enemies of Gud shall be gathered unto the fire urged on in bands; until when they reach it, their ears and their eyes and their skins shall bear witness against them of their deeds: And they shall say to their skins, "Why have ye borne witness against us?' They answer, 'God who giveth a voice to all things giveth us a roice."

(RODWELL).

“Wayusabbihu 'rr'adu bihamdihi wa 'Imalaikatu min khaifatihi wa yursilu 'ssawaiqa fa yusibu biha man yashau wa hum yujadiluna fl 'llahi."

KoraN, chap. 13 .

"And the thuniler uttereth Ilis praise and the angels also for awe of Him; and IIe sendeth His bolts and sniteth with them whom He will, while they are wrangling about God."

(ROIWELL).

"Wujud-i-tu shahr ast pur nik wa bad,

Tu sultan, wa dastur-i-dana, khirad."

Bostan of S'ADI, chap. j.

" Thy body is a city full of good and bad,

Thou art sultan; and wisdom is the prime minister."

(CLARKE). 
"Ya Aba Huraira! zurni ghiban, tazdad hubban."

Saying of Muhammad.

"O Aba Huraira! Visit me every second day and thou wilt increase our friendship" (i.e., not every day).

"Ya Ali az jumla-e-ta'at rah

Bar guzin tu saya'e-khass Allah;

Tu birau dar saya-e-aqil guriz.

Ta rihi z'an dushman pinhan sitiz;

Az hama ta'at inat bihtar ast

Sabaq yabi bar har an sabiq ki hast."

JALALUdDIN RUMr.

"O Ali ! out of all forms of religious service

Choose thou the shadow of that dear friend of God!

Do thou seek refuge in the shadow of the wise man

That thou mayest escape thy fierce secret foes,

Of all forms of service this is fittest for thee

Thou shalt surpass all who were before thee." WHinfield.

“Ya ayyuha 'lladhina amanu 'sbiru wa sabiru wa rabitu wa 'ttaqu 'llaha laallakum tuflihun."

KoRAN, chap. 3.

"O ye who believe! suffer patiently and excel in patience, and be firm and fear God. HIaply it shall be well with you."

(RODWELL).

"Ya ayyuha 'lladhina amanu 'jtanibu kathiran mina 'dhdhannl, 'inna ba'dha 'dhdhanni 'ithmun wa la tajassasu wa la yaghtab ba'dhukum ba'dhan, ayuhibbu 'ahadukum 'an yakula lahma 'akhihi maitan, fakarihtumuhu."

KORAN (chap. 49).

"O believers, avoid frequent suspicions, for some suspicions are a crime ; and pry not; neither let one of you traduce another in his absence. Would any one of you like to eat the flesh of his dead brother? Surely ye would loathe it."

(RODWELL).

"Ya ayyuha 'Imuzmir haman, la tahamm

Innaka in tuqdira laka 'lhama, taham."

Abu'l Ala.

" Oh thou whose heart is full of care, fear not; if fever be ordained for thee, thou shalt take it."

"Ya bani Adama qad 'anzalna 'alaikum libasan yuwari sawatikum warishan wa libasu 'ttaqwa dhalika khairun dhalika min ayati 'llahi la'allahum yadhdhakkarun."

KORAN, chap. 7 .

"O children of Adam! now have we sent down to you raiment to hide your nakedness, and splendid garments; but the raiment of piety-this is best. This is one of the signs of God : haply man will be monished."

(RODWELL). 
“Ya bani 'Isra'lla 'dhkuru ni'amatia 'llati 'an'amtu alaikum wa'inni fadhaitukum "ala'i'alamin."

KORAN, chap. 2.

"O children of Israel, rementer My favour wherewith I showed favour upon you ; and that to you above all creatures have I been bounteous."

(KOINELL).

"Ya bint / la tafrihi bithubi arsuka, ya ma warahu mina 'shshaqa." ARAHC Proverb.

"Girl! don't exult in thy wedding dress. Ah ! how much trouble is behind it."

(BURTON).

"Ya bunayya 'aqimi 'ssalata wa'amur bi'lma'rufl wa'nahu 'ani 'lmunkari wa'sbir 'ala ma'asabaka "inna dhalika 'adhmi'l'umurf."

KorAN, chap. 3r.

"O my son : observe prayer and enjoin the right and forbil the wrong, and be patient under whatever shall betide thee, for this is a bounden duty."

(RODWELL).

"Ya bunayya innaka mas'ulan yauma 'lqiyamati madha iktasabta la yuqalu biman "intasabta."

Gulistan, chap. 7.

"O my son ! thou wilt be asked in the day of resurrection,

'What hast thou acquired?' not 'from whom hast thou sprung?'"

EASTWICK.

"Yad bad an ki chu chashmat ba"itabam mi-kusht

Mu'ajiz Isawiyat dar lab-i-shakkar kha bud.

Yad bad an ki sabuhe zada dar majlis-1-uns

Juz man wa yar nabudim, wa Khuda ba ma bud."

HaFiz.

"Be memory of that time when we with reproach thine eye slew

When in thy lip sugar-devouring the miracle of Jesus life-giving was;

Be memory of that time when in the assembly of companionship we drained the morning cup;

We were not, save I and the friend and with us God." (Clarke).

"Ya durr ba har du dast kunad khwaja dar kinar,

Ya mauj ruzi afgandash murda bar kinar." Gulistan, chap. x.

"Or with both hands the nierchant shall one day embrace the gold,

Or by the waves his lifeless form shall on the strand be rolled."

(EASTWICK).

"Ya Ybadia 'lladhina 'asrafu 'ala 'anfusihim la taqnatu min rahmati 'llaht inna 'llaha yaghfiru 'dhdhunuba jami'an." 
"O my servants who have been extravagant against their own souls ! be not in despair of the mercy of God : verily God forgives sins, all of them."

(Palmer).

"Yak chand bakudaki b'ustad shudim,

Yak chand b'ustadi khud shad shudim,

Payan-i-sukhan shinau ki mara chi rasid

Az khak bar amadim wa bar bad shudim."

Omar Khavyam.

"I studied with the masters long ago, And then myself taught pupils what I know ;

Hear now the sum and upshot of it all, "We come from earth and to the winds we go."

"Yak dasta gul dimagh parwar

WHINFIELD. Az khirman sad giyah khushtar."

SHAHI.

"One bunch of roses with their ravishing odour is worth more than a garden filled with a hundred common shrubs and grasses."

"Yak dast bamusahafem wa yak dast bajam,

(Ouseley).

Gah nizd-i-halalam, wa gahe nizd-i-haram,

Mayem darin gambad-i-flruza rukham

Na kaflr-i-mutlaq, na musulman-i-tamam."

Omar Khayyam.

" One hand with Koran, one with wine-cup dight

I have incline to wrong, and half to right;

This crystal azure dome beholds in me

A sorry Moslem, yet not heathen quite.'

(WHINFIEI.D).

Yake Allah me gufti shabe,

Taki shirin gardad az zikarash labe;

Guft Shaitanash 'khamush, ey sakht ru,

Chand gui akhir ey bisyar-gu,

Mi n'ayad yak jawab az pish-i-takht

Chand "Allah" mi zani ba rue sakht.'

U shikasta dil shud wa binihad sar

Did dar khwab u Khizr ra dar hazar.

Guft 'Hin az zikr chun wa manda'i

Chun pashimani azan k'ash khanda'i

Guft "Labeikum" na miayad jawab,

Za an hamitarsam ki basham radd bab.'

Guft Khizrash ki khuda guft 'In ba man

$\mathrm{K}$ i birau ba u bigu "ey mumtahan!

Guft in 'Allah' tu labeik-i-ma'st,

In niyaz wa suz dardat paiyik-i-mast,

Hiliha wa chara wa juiha-i-tu

Jazb-i-ma bud wa kushad an pa-i-tu,

Tars wa 'ishq-i-tu kamand lutf m'ast

Zir har "Ya Rabb'-i-tu "Labeikihast."

Jalaluddin Rumi. 
" That person one night was crying ' $O$ Allah !'

That his mouth might be sweetened thereby,

And Satan said to him 'Be quiet, $O$ austere one !

How long wilt thou balsble $\mathrm{O}$ man of many words?

No answer comes to thee from nigh the throne,

How long wilt thou cry "Allah!" with harsh face?"

That person was sad at heart and hung his head

And then beheld Khirr present before hin in a vision

Who said to him 'Ah! thou hast ceased to call upon God,

Wherefore repentest thou of calling upon Him?"

The man said "The answer "Here am I" came not,

Wherefore I fear that I am rcpulsed from the door.'

Khizr replied to him 'God has given me this command

Go tu him and say "O much tried one !

That calling 'Allah' of thine was my 'Here am I ;'

And that pain and longing and ardour of thine was my messenger ;

Thy struggles and strivings for assistance

Were My attractions and originated thy prayer.

Thy fear and thy love are the covert of My mercy,

Each 'O Lord!' of thine contains many 'Here am I's."

"Yake bacha'e gurg mi parwarid,

Chu parwarda shud khwajara bar darid." Gulistan, chap. 3.

WHINFIELD.

"A wolf's whelp had been fostered till one day Grown strong, it tore its master's life away." .

"Yake dar baharan biyafshanad jau

Chi gandum sitanad biwaqt-1-dirau?" BOSTAN OF S'ADI, chap. 9.

"A certain one scatters barley in the spring, How may he take wheat at reaping time?" (CLARKE).

" Yake halqa'e k'aba darad bidast,

Yake dar kharabat uftada ast;

Gar in bikhand ki nugzaradash?

War anra birand ki baz aradash?"

Bostan of S'Adi.

"This one has in his hand the door-ring of the K'aba

That one is fallen intoxicated in the tavern,

If God calls this one, - who may not permit him?

And if He drives away that one,--who may liring him back ?"

(ClaRKe).

"Yake juyam, yake danam, yake binam, yake khwanam,

Huwa 'lawwal, huwa 'lakhir, huwa 'lzahir, huwa 'lbatin."

Diwan-I-Shams-I-TABRiz.

" One I seek, one I know, one I see, one I call.

He is the first, He is the last, He is the outward, He is the inward."

(Nichtolson). 
" Yake miguft ' khush budi jahan

Gar na budi bak marg andar miyan';

An digar guft 'ar na budi marg hich,

Ki na arzidi jahan pich pich

Kharmane budi bar dasht afrashta,

Muhmal wa nakufta bugzashta." "

JALALUDDIN RUMI.

" One said "The world would be a pleasant place, If death never set font within it';

Another answered 'If there were no death,

The complicated world would not be worth a jot.

It would be a crop raised in the desert

Left neglected and never threshed out."

(WHINFIELD).

"Yake pasban wa yake padshah,

Yake dadkhwah wa yake tajkhwah,

Yake kamran wa yake mustamand,

Yake shadman wa yake dardmand,

Yake tajdar wa yake bajdar

Yake sarfaraz wa yake khaksar,

Yake namurad wa yake kamkar,

Yake bi nau wa yake maldar."

PandNama of S'Adi.

"One is a watchman, another a king,

One imploring justice, another coveting a crown;

One gratitied and another wishing,

One merry and another sad,

One wearing a crown and another paying tribute,

One elevated and another humble,

One disappointed and another blessed,

One poor and another rich."

(GLADIVIN).

“ Yake pursid az an gum karda farzand,

$\mathrm{Ki}$ 'ey pak gauhar, pir-i-khiradmand,

Za misarash bui pairahan shunidi,

Chara dar chah-i-kan'anash na didi?'

Baguft, 'ahwal-i-ma barq-i-jahan ast,

Dame paida, wa digar dam nihan ast.'"

Gulistan, chap. 2.

"To that bereaved father * one once said

'Aged sire, on whose bright soul truth's light is shed

Froin Egypt his t coat's scent thy nostrils knew

In Canaan's pit why was he hid from view?'

'My state' he said 'is like heaven's flashing light,

One moment shown, the next concealed in night.',

EASTWICK.

* Jacob.

† Joseph's. 
" Yake qatra baran za abare chakid,

Khijal shud chud panha'e darya badid,

Ki 'jae ki daryast, man kistam?

Gar u hast haqqa kd man nistam.'

Chu khudra bachashm-t-hiqarat badid,

Sadaf dar kinarash bi jan parwarid."

Bostan of S'ADI, chap. 1.

"A rain-drop dropped from a cloud

It became ashamed when it heheld the amplitude of ocean.

Saying "Where the ocean is, what am I?

If it be by God! then I am not.'

When it regarded itself with an eye of contempt

A shell cherished it with fervour in its bosom."

(Clarke).

" Yakera bizindan darash dustan

Kuja manadash "aish dar bustan."

BOSTAN OF S'ADI.

"How can he whose friends are in a dungeon, any longer find enjoyment in his garten?"

(FALCONER).

" Yakera ki pindar dar sar buwad

Mapin dar hargiz ki haqq bishanawad." Bostax of S'ADr, chap. 4.

"One in whose head is conceit

Think not that he will ever listen to truth." (Cl.ARKE).

" Yakera zishtkhue dad dushnam

Tahammul kard wa guft 'ey nik farjam,

Badtar zanam ki khwaht guftan ani,

Ki danam 'aib-i-man chun man na dani.'"

Gulistax, chap. I.

"An ill-bred fellow once a man reviled

Who patient hore it, and replied 'Good friend,

Wurse am I than by thec I could be styled

And better know how olten I offend,"

(EAST".ICK).

- Yake tukhm bar khak az an mi nihad

K1 ruz-1-farumandagi bar dihad."

Bostan of S'ADI chap. 2.

"Ile places a seed in the dust for the reason

That it may in the day of distress, give fruit."

(ClaRKE).

“Yakflaka ma balaghuka 'Imahall; in 'ajaza dhtlun ani shakhsika fa la yajazana 'ani adhuin minka.

A Bu't, Ala.

"Be satisfied with what brings you to your destiuation; if there is not shade enough for your whole body, there is sure to he enough for one of your members."

D. S. MARGol.iouth.

"Yak gul bi-khar dar in bagh nist,

Lala'e u bi asar-i-dagh nist, Tigh zanad bar tu wa gui khur ast Zard kunad ruiyat wa gui zar ast." 
" Ne'er in that garden blooms a thornless rose,

Nor spotless tulips there their charms unfold; And yet thou seest sunbeams in its blows,

It gilds thy visage and thou eallst it gold." (EAsTwick)

"Yak jara 'mai za mulk-i-Kaus bihast

Wa za takht-i-Kobad wa mulkat-i-Taus bihast

Har nala ki ashiqe bar arad ba sahar

Az na'ra'e zahidan-i-salus bihast."

Omar Khayyam.

"One draught of wine outweighs the realm of Tus,

Throne of Kobad and crown of Kai Kaius,

Sweeter are s'ghs that lovers heave at morn

Than all the groanings zealot throats produce."

WHINFIELD.

"Yak jau az khirmani natawanad bardasht,

Har ki dar kui fana dar rah-i-haqq dana nakisht." H HFIZ OdE, 6r.

" Not one grain of the sheaves of life is stored by those who trod

This pathway of mortality and sowcd to seed for God."

"Yakjau gham-i-ayyam na darim khushim,

BICKNELL.

Gar chasht buwad sham, na darim khushim,

Chun pukhta ba ma na mi-rasad az matbakh,

Az kas tam'a-i-kham nadarim khushim."

OMAR KHAYYaM.

"These worldly cares I rate not at one grain,

So I eat once a day, I don't complain ;

And since earth's kitchen yields no solicl food

I pester no man with petitions vain." WHINFIELD.

"Yak jazb-i-haqq bih za sad kushish ast." Diwan-1.Shams-I-Tabriz.

" One impulse from Gnd is better than a hundred efforts."

(NICHOLSON).

"Yak lahza ghafl gashtam wa sad sala raham dur shud."

The Dabistan.

"During one moment I was heelless and he was removed from me a journey of a hundred years."

(Shea).

"Yak nan ba du ruz agar shawad hasil-i-mard,

Wa'z kuza'e shikasta'e dam-i-abi sard;

Makhdum-i-kam az khudi chira bayad bud

Ya khidmat-i-chun khud'i chira bayad kard?" Oмak Khayyam

"Ssoner with half a loaf contended he

And water from a broken cruck, like me,

Than lord it over your inferiors,

Or to your equals bow the vassal knee." Whinfield. 
" Yak ruz falak kar mara saz na dad, Hargiz sue man dame khush awaz na dad, Yak ruz dame za shadmani na zadam, K'anruz badast-i-sad ghamam baz na dad."

Omar Khavyam.

" For me heaven's sphere no music ever made, Nor yet with soothing voice my fears allayed, If e'er I gained a breathing space of joy , Into woe's grip I was at once betrayed." Whinfield.

"Yak ruz za band-i-'alam azad na yam,

Yak dam zadan az wujud-i-khud shad na yam, Shagirdi-i-ruzgar kardam bisyar

Dar daur-i-jahan hanuz ustad na yam."

Omar Kuayyam

"Never from worldly toils have I been free, Never for one short moment glad to be ; I served a long apprenticeship to fate, But yet of fortune gained no mastery." IVhinfield.

"Yak zamane subbate ba auliya

Bihtar az sad sala ta'at bi riya ;

Gar tu sang-1-khara wa marmar shawi, Chun ba sahib dil rasi, gauhar shawi."

Jalaluddin Ruml

"Society with saints no doubt's of great avail

'To piety it leads ; 'God's fear shall never fail.'

Thou wast a very rock, a worthless pebble-stone,

By saints' communion fined, a pearl of price thou'st shone."

(REDhouse).

“ Ya lahfa nafsi 'ala 'shshababi wa lam afqid bihi idh faqadtuhu 'amama

Idh 'asbahtu 'rraita wa'lmaruta 'ila 'adna tajari w'anfudhu 'llimama

La taghbiti 'Imar'a 'an uqala lahu 'amsa fulanan lisinnihi hakama 'In sarrahu tulu 'umrihi falaqad 'adha 'ala 'lwajhi tulu ma salima.'s

AMribn Kamiah.

"Alas my soul ! for youth that's gone

No light thing lost I when he fled!

What time I trailed my skirts in pride, And shook my locks at the tavern's door. Nay, envy not a man that men Say 'Age has made him ripe and wise.' Though thou love life and live long safe Long living leaves its print on thee." 
"Ya laita qabla maniyati

Yauman 'afuzu bimuniyati,

Nahrin talatama rukbati

Fa'adhallu 'amla'un qirbati."

Gulistan, chap. 3.

"O would that before my death, I might one day obtain my wish. A river dashing its waves against my knee! Then would I not cease to fill my leather water-bag."

(PlatTS).

"Ya mala'ikiti, laqad isthaiytu min 'abdi wa laisa lahu ghairi faqad ghafartu lahu."

Gulistan (Preface).

"O my angels, verily I am ashamed by reason of my servant and he hath no God but myself; therefore of a surety I pardon him."

" Ya qillatu'zzad wa wahshata 'ttariq!"

(EASTIVICK).

"Oh! the scantiness of the provision and the terrors of the road!"

“ Yaquluna 'inna jamala 'lfata wa zinatahu 'adabun rasikhu,

Wa ma'in yazinu siwa 'Imukthirina wa ma taudu sudadihi shamikhu,

Fa'amma 'lfaqiru fakhairun lahu mina'l'adabi 'lqursu wa'lkamikhu,

Wa 'ayya jamalin lahu 'an yuqala 'adibun yu'allimu au nasikhu?"

MAQAMAT OF HARIRI, chap. 44.

"They say that a man's chief adornment and pride, and his beauty is learning, deep-rooted sound,

Alas, it adorns but the wealthy and him, whose summit of lordship is rising aloft,

But as for the poor man, I reckon for him far better than learning a loaf and a stew;

What beauty bestows it on him if they say 'A scholar, a school drudge, or may be a clerk?"

STEINGASS.

"Yaqut ra muqabil khar muhra mi-nihand

Sang-i-sujah ba nirkh zar surkh mi-kharand." AkhlaQ-I-Jal.ali.

"Men will risk a jewel like the merest toy

And buy for stirling gold some base alloy."

"Ya Rabb, ba dil-i-asir-i-man rahmat kun,

(THOMPSCN).

Bar sina-e-gham-pazir-i-man rahmat kun,

Bar pa-e-kharabat rau-i-man bakhsha,

Bar dast piyala gir-i-man rahmat kun."

OMar Khayyam.

" Pity O Lord, this prisoned heart I pray,

Pity this bosom stricken with dismay,

Pardon these hands that ever grasp the cup,

These feet that to the tavern ever stray." (Whinfield). 
"Ya Rabb, za qabul-1-warazdam baz rihan, Mashghul khudat kun za khudam baz rhan, Ta hushyaram za nik wa bad midanam Mastam kun wa az nik wa badam baz rihan." OMAR KHAYYAM.

"From self-reliance, Lord, deliver me, Sever from self and occupy with Thee, When sober, I am bondman to the world, Make me beside myself and set me free."

" Yar chun raft an bakhubi az hama 'alam fazun,

(WHINFIEID). Dar faraqash az hama 'alam fazun khwaham grist, Rizad aknun khun dil as guna zardam bakhak Chun rawam dar khak ham z'in guna khun khwaham grist." Jam, Blharistax, chap. 5.

"As that friend of mine departed who is better than the whole world, I shall bemoan his loss nore than the whole wold, My heart now sheds tears of blood from my pale cheek to the ground, When I depart under giound, I still shall weep in this inanner."

"Yar-1-kuhan ba hich ru ma dih az dast

Bahr harifan nau ki nik nabashad."

(REHATSEK).

"Do not an old and well tried friend forego, For new allies, for this may end in woe." Eastwick.

"Yar-i-na paedar dust ma dar.

Dusti ra na shayad in ghaddar."

Gulistán (Preface).

"Hold not as friend this comrade light (i.e., the world)

With one so false no friend ship plight." EASTwick.

"Yas'alunaka 'ani 'Iruhi quli 'rruhu min 'amri rabbi wa ma 'utitum mina 'I4lmi 'illa qalila." . KorAs, chap. 17.

"They will ask thee of the spirit. Say "The spirit comes at the bidding of my Lord, and ye are given but a little knowle.'ge thereof.'",

(PAIMER).

"Yas 'alunaka 'ani 'ssa'ati 'ayyana mursaha qul 'innama 'ilmuha 'inda rabbi la yujalliha ilwaqtiha 'illa huwa thaqulat fi' ssamawati wa'l'ardht la t'atikum 'illa baghtatan." KoRAN, chap. 7.

"They will ask you about the hour, for what lime it is fixed. Say "The knowledge thereof is only with my Lord; none shall manifes? it at its time but $\mathrm{He}$; it is heavy in the heavens and the carth; it will not come to you save on a sudden."

(P'AIMER).

\section{shan." \\ “Yas'aluhu man fl' ssamawati wa'l'ardhi, kulla yaumin huwa fi}

"To Him maketh suit all that is in the heaven and the earth. Every day doth some new work employ lim."

(RODWELI.). 
" Yatime ki na karda Kuran durust

Kutub khana'e chand millat bishust ;

Chu azamash bar angikht shamshir-i-bim

Ba muajiza mujan-i-qamr zad du nim."

Bostan OF S'ADI.

" The orplian (Muhammad) who, the Kusan uncompleted, Washed the library of (effaced) so many religions

When anger drew forth his sword of terror

Struck by a miracle the waist of the moon in two halves."

(Clarke).

“Yauma'idhin yasduru 'nnasu 'ashtatan liyurau 'amalahum faman ya'mal mithqala dharratin khairan yarahu, waman ya'mal mithqala dharratin sharran yarahu."

KORAN, chap. 99 .

" On that day shall men come forward in throngs to behold their works, and whosoever shall have wrought an atom's weight of good shall behold it, and whosoever shall have wrought an atom's weight of evil shall behold it."

(RODWELL).

"Yauma "inda rabbika ka'alfi sanatin mimma ta'uddun."

KORAN, chap. 22. $r .46$

" "A day with thy Lord is as a thousand years, as ye reckon them."

" Yauma 'lkhamisi laqad faraqtu ahababi,

(RODWELL).

Wa ghassaluni 'ala lauhin mina 'lbabi,

Wa harra duni thiyaban kuntu labisaha

Wa 'lbasuni thiyaban ghaira 'athwabi.

Wa hammaluni 'ala 'anaqi arba'atin

Ila 'Imusalla wa ba'dhu nnasi salla bi.

Wa shayyauni ila darin muqnazaratin

Yafna 'zzamanu wa la yuftah laha babi."

Alif Laila wa Laila.

"On the fifth day I parted from those I loved, And they washed me on a plank from out the door, They stripped me of the clothes I erst was dressed in, And clad me in raiment that was other than mine own. And they bore me away on four men's necks, To a place of prayer and some of the people prayed for me, And they accompanied to a dwelling house arched in,

Let all mankind perish yet will my door not open." TORRENS.

"Yauma naqulu lijahannama hali 'mtal'ati wa taqulu hal mir. mazid."

KORAN, chap. 50. $\quad$ V.29

" On that day will we cry to hell 'Art thou full?' And it shall say "Are there more?",

(RODWELL).

"Yauma tabayadhdhu wujuhun wa taswaddu wujuhun fa'amma lladhina 'swaddat wujuhuhum 'akfartum b'ada imanikum fadhuku 'l'adhaba bima kuntum takfurun."

KORAN, chap. 3 . 
"On the day when faces shall turn white and faces shall turn black! And as to those whose faces shall have turned black. . . "What! after your belief have ye become infidels. Taste then the chastisement for that ye have been unbelievers." "

(ROINELI.).

"Yauma tajidu kullu nafsin ma 'amilat min khairin muhdharan wa ma 'amilat min su'an tawaddu lau 'anna bainaha wa bainahu 'amadan ba'idan."

Koran, chap. 3.0 .28

"On that day shall every soul find present to it, whatever it hath wrought of good; and as to what it hath wrought of evil it will wish that wide were the space between itself and it."

(RODWELL).

"Yauma takunu 'ssamau ka'lmuhli, watakunu 'ljlbalu ka'l'ihni, wa la yasalu hamimun hamiman yubassarunahum."

KORAN, chap. 70.

"The day when the heaven shall become as molten brass; and the mountains shall hecome like flocks of woul, and friend shall not question of friend, thougls they look at each other."

(RODWEI.L).

"Yauma tara 'Imuminina wa 'Imuminati yas'a nuruhum baina 'aydihim wabi 'aymanihim bushrakumu 'lyauma jannatun tajri min tahtiha 'l'anharu."

KORAN, chap. 57.

"One day thou shalt see the believers, men and women, with their light running before them, and on their right hand. The angels shall say to them "Good tidings for you this day of gardens beneath whose shades the rivers flow."

(RoDWELL).

"Yauma taraunaha tadhhalu kullu murdhi'atin 'amma 'ardha'at wa tadha'u kullu dhati hamlin hamlaha wa tara 'nnasa sukara wa ma hum blsukara wa lakinna "adhaba 'llahi shadid."

KORAN, chap. 22.

"On the day when ye shall lehold it (the last judgment), cvery suckling woman shall forsake her sucking babe; and every woman that hath a burden in her womb shall cast her burden; and thou shalt see men drunken, yet are they not drunken: but it is the mighty chastisement of God."

(KODWELL).

Yauma yajma'ukum liyauml 'ljam'a dhalika yaumu 'ttagabuni wa man yumin bi 'llaht wa y'amal salihan yukaffl 'anhu sayyatihi wa yudkhllhu jannatin tajri min tahtiha 'lanharu khalidina fiha 'abadan dhalika 'Ifaudhu 'l'adhim.

Koras, chap. 64 .

"The day when IIe shall gather you together fur the day of the assembly will be the day of mutual deceit, and whoso believeth in God and does what is right, his deeds of evil will He cancel and He will bring him into the gardens beneath whose sharles the rivers flow, to abide therein for evermore. This will be the great bliss."

(ROLWELLL).

"Yauma yandhuru 'Imaru ma qaddamat yadahu wa yaqulu 'lkaflru ya laltanl kuntu turaba." Koras, chap. 78. 
"The day on which a man shall see the deeds which his hands have sent before him; and when the unheliever shall say 'Oh! would I were dust!'"

(RONWELL).

"Yauma yaqulu 'Imunafiquna wa 'Imunafiqatu lilladhina amanu 'ndhuruna naqtabis min nurikum qila 'rji'u wara'akum fa'ltamisu nuran fadhuriba bainahum bisurin lahu babun batinahi flhi'lrahmatu wa dhahiruhu min qibalihi 'l'adhab."

KORAN, chap. 57 .

"On that day the hypocrites both men and women shall say to those who lelieve, 'Tarry for us that we may kindle our light at yours.' It shall be said 'Return ye back, and seek light for yourselves.' But beiween them shall be set a wall with a gateway, within which shall be the Mercy, and in front, without it, the Torment."

(RODWELL).

"Yawadda bi' jadha 'lanfl lau an dhaharaha

Mina 'nuasi a'ra mina sarat adim."

(ANON).

" He would give his nose if only the earth's surface were as clear of men as tanned leather is of hair."

D. S. MARgoliourh.

"Ya wafa khud na nabud dar 'alam,

Ya magar kas dar in zamana na kard.

Kas niamukht ilm-i-tir az man

Ki mara "aqibat nishana na kard."

Gulistan, chap. $\mathrm{t}$

" On earth there is no gratitude, I trow, Or none perhaps to use it now pretend. None learn of me the science of the bow Who make me not their target in the end."

(EASTWICK).

"Ya waiha man 'andharahu shaibuhu

Wa huwa 'ala ghayy 'ssiba munkamish,

Yagshu 'ila nari 'lhawa b'ada ma

'Asbaha min dh'ufl 'lghuwa yart'aish,

Wa yamti 'llahwa wa yatadduhu

'Auta ma yaftarishu 'Imuftarish." Maq+MAT of Hariri (chap. 41).

"Woe to the man, who, warned by his hoariness, still blindly rushes along on youth's folly bent,

And glances lrack on pleasure's fire when all his limbs already from weakness shake,

Who rides the steed of wantonness which be deems a softer coucl than chamberlains ever spread."

STEINGass.

"Ya waridan sura 'aishin kulluhu kadarun,

'Anfaqta safwaka $f$ 'ayyamika 'lauwwali ;

Fima 'qtahamuka lujja 'Ibahri tarkabuhu, Wa' anta yakflka minhu massatu 'lwashali."

Al Tughrai. 
" But why exhaust life's vapid bowl

And suck the dregs with sorrow foul,

When long ere this my youth has drained

Whatever \%est the cup contained?

Why should we mount upon the wave

And ocean's yawning horrors brave

When we may sivallow from the tlask

Whate'er the wants of mortals ask."

J. 1). CAki.yle.

"Ya zar ba har du dast kunad khwaja dar kinar,

Ya mauj ruze afghandash murda bar kinar.

Gulistan, chap. x.

"Or with both hands the merchant shall one day embrace the gold, Or by the waves his lifeless form shall on the strand be rolled."

"Yudhannu bi 'dhdhanini wa yunaflsu fl 'ththamini."

(EASTWICK).

Magamat of HaRiRi, chap. 4 .

"Only he who clings should be clung to; only he who is valuable should be prizerl."

(Chenery).

"Yu'jibuka 'ttakathuru bima ladeika wa la tadhkuru ma baina yadeika wa la tuball 'alaka 'am aleika, 'atadhunnu 'an satutruku 'sudan wa 'an la tuhasibu ghadan am tahsabu 'anna 'Imauta yaqbalu 'rrusha au yumaiyyizu baina 'lasadi wa 'rrasha."

Maqamat of HaRiri, chap. 2 r.

" It pleases thee to increase what belongs to thec but thou rememberest not what is before thee; thou carest not whether the accuunt shall be in thy favour or against thee! Dost thou think thou shalt be left at large, or that thou shalt not be reckoned with to-morrow? Or dost thou count that Deatk will take bribes; that he will distinguish between the lion and the fawn ?"

CHENERY.

"Yuriduna 'an yutfiu nura 'llahi bi'afwahihim wa yaba 'llahu 'illa 'an yutimma nurahu wa lau kariha 'lkafirun."

KorAN, chap. 9.

"Fain would they put out God's light with their mouths ; but God only desireth to perfect his light, albeit the infidels abhor it." (Rovwlic.).

" Yusdi wa yulhimu fi 'lmadhalimi walighan

Fi wirdiha tauran wa tauran muwaligha

Ma'in yubala hina yattabi'u 'lhawa

Fiha 'a'aslaha dinahu 'am 'autagha

Ya wayhahu lau kana yuqinu annahu

Ma halatun illa tahulu lama tagha." MaQniat of Hariri, chap. 2t.

" He weaves warp and woof in tyrannies; now lapping at their well, now lidding others to lap,

Nor cares he when he is following his desires in them whether he maintains his religion or destruys it.

Oh woe to him, if he knew weil that there is no state but changes, surely he would not transgress." CHENEKY. 
"Yusuf-i-gum gashta baz ayad bakan'aan gham makhur, Gulba'e ihzan shawad ruze gulistan, gham makhur, Ey dil-i-ghamdida, halat bih shawad, dil bad makun, Wa in sar-i-shurida baz ayad ba saman, gham makhur, Gar bahar-i-'umr baz ba takht-i-chaman, Chatri gul bar sar kashi, ey murgh-i-shabkhwan, gam makhur. Han ma shau na-ummid chun waqif na'i az sirr-i-ghaib Bashad andar parda bazihai pinhan, gham makhur."

HAFIZ ODE 284.

" "Lost Joseph shall return to Kanaan's land-despair not, Affliction's cell of gloom with flowers shall bloom-despair not, Sad heart, thy state shall mend; repel despondency, Thy head confused with pain shall sense regain-despair not, When life's fre:h spring returns upon the dais mead O night hirt o'er thy head the rose shall spread-despair not, Hope on, though things unseen may baffle thy research, Mysterious sports we hail behind the veil-clespair not."

(BICKNELi.).

"Za bad asl niki ma darid ummid

Ki zangi na gardad ba shustan sufld."

Anwar-I-SuIIEIL1.

"Hope nort that evil natures good will show, For rust, through washing, white will never grow."

EASTWICK.

“" Za bagh-i-'ishq talab kun 'aqida'e shirin

Ki tab'a sirka farushast wa ghwara afshari."

DIWAN-I-ShaMS-I-TABRIz.

"Seek sweel syrup in the garden of love,

For nature is a seller of vinegar and a crusher of unripened grapes."

(NICHOLOSON).

"Zaban amad az bahr shukr wa sipas

Bighibat nagardanadash haqq shinas." Bostan of $\mathrm{S}^{4} \mathrm{ADt}$, chap. 8.

"The tongue came (from God) for thanks and praise,

The grateful one moves it not in slander."

(CI.ARKE).

"Zaban burida ba kunji nishast summ wa bukum

Bih az kase ki zabanash na bashad andar hukin."

Gulistan, Preface.

"Better who sits in nooks cleaf, speechless, idle, Than he who knows not his own tongue to bridle.'

"Zada az andishha'e khub-i-tu wildan wa hur

(EASTWICK).

Zada az andishha'e zisht-i-tu div-i-kalan;

Sirr wa andisha munhadis bin shuda gasr wa sara

Sirr-i-taqdir-i-azlra bin shuda chandin jahan."

DIWAN-1-ShaMS-1-TABRIZ. 
"From thy good thoughts are born the boys of Paradise and the houris, From thy evil thoughts is born the great demon (Iblis),

See how the secret thought of the geometrician has become a castle or a palace,

See how the hidden Providence withont beginning has become this mighty universe."

(NiCHOLSON).

"Zadam tisha yak ruz bar tall-i-khak

Ba gush amadam naia'e dardnak

Ki 'zinhar agar mardi, ahistatar,

Ki chashm wa bina, gush wa rue ast war sar." BOSTAN op S'ADr.

"I one day struck a mattock against a hillock of earth; a plaintive expostulation broke moaning on my ear: "Beware, if thou art mortal; more gently ! for this is an eye, an ear, a face, a head." (FALCONEK).

"Za dud-1-dil-i-khalq ghafl mabash

Ma kun mardum azari ey tundrae

Ki nagah rasad bar tu qahr-i-khudae." PANDNaMA of $\mathrm{S}^{6}$ Adr.

" Slight not the sighs of the hearts of God's creatures,

Exercise not severity and mornseness

For the vengeance of God will overtake thee unawares."

" Za dushman shinau sirat-i-khud, ki dust

GLADWIN.

Har an chi az tu ayad, ba chashmash nikust."

Bostan of S'ADi, chap. $x$.

"Hear thine own character from the enemy, because"

In the friend's eye, whatever comes from thee is good."

(CLAKKE).

"Za gush pamba birun ar wa dad-i-khalq bidih, Wa gar tu me na dihi dad, ruz-1-dadi hast."

Gu'Listan, chap. I.

“ Unstop thy ears, thy people's wants relieve,

If not, a day shall come, when all their rights receire."

* Zahidi dar pilas-pushi nist

(EASTWICK).

Zahid-i-pak bash wa atias push ;

Tark-i-dunya wa shahwatast wa hawas

Parsa'i,-na tark-i-jama wa bas."

Gulistan, chap. 2.

"Virtue lies not in sackcloth coarse and sad,

Be purely pious and in satin clad;

True holiness consists in quitting vice,

The world and lust, not dress ;-let this suffice."

"Zahiran bar zan chu ab ar galib'i

Batinan maghiub wa zan ra talib'i."

(EASTWICK).

Jalaluddin Rum.

"Apparently thou art the ruler of thy wife like water over fire, In reality thou art ruled by and suppliant to her." WHINFIELD. 
"Zahir-i-hal-i-'arifan dalqast

Inqadr bas ki rue dar khalqast ;

Dar 'amal kush wa har che khwahi push

Taj bar sar nih wa 'alam bar dush."

Gulistan, chap. 2.

" Rags * are the exiernal sign of holiness

Sufficient, - for men judge by outward dress ;

Strive to do well and what thou pleasest wear,

Thy head a crown, thy arm a flag may bear."

"Zahr maran mar-ra bashad hayat

Nisbatash ba admi amad mumat."

(EASTWICK).

JALALUdDin Rumi.

"Serpents" poison is life to serpents,

In relation to mankind it is death." (WHINFIELD).

"Za kar-i-basta ma'andish wa dil-i-shikasta ma dar ki ab-i-chashma'e haiwan darun tarikast."

Gulistan, chip. $x$.

"Have no doubts because of trouble nor be thou discomfited; for the water of life's fountain springeth from a gloomy bed." (EAsTwick).

" Zalimera khufta didam nim ruz

Guftam 'in fltna ast, khwabash burda bih,'

Anki khwabash bihtar az bidariast

Anchunan bad zindagani murda bih."

Gulistan, chap. I.

"A tyrant lay, his noon-tide slumber taking, Said I "tis best this scourge should sleeping lie, And he whose sleep is better than his waking,

'Tis best for such an evil one tu die."

(EASTWICK).

“ Zamin shura sambal bar niyarad

Dar u tukhm 'amal za'i magardan ;

Nikui ba badan kardan chunanast

Ki bad kardan ba jae nik mardan."

Gulistan, chap. I.

" Salt ground will not the precious spikenard bar

Waste not thereon the seed of thy emprise ;

Who benefits on evil men confer

Upon the good no less heap injuries."

(EASTWICK).

“ Z'an dam ki amadasti andar jahan-i-hasti,

Pishat ki ta barasti binhada nirdubanast;

Awwal jamad budi, akhir nabat gashti,

Angah shudi tu haiwan; in bar tu chun nihanast?

Gashti az an pas insan ba'ilm wa 'aqI wa iman

Bingar che kui shud an tan k'u juzwi khakdanast,

$\mathrm{Za}$ insan chu sair kardi, bishakk flrishta gardi,

Be in zamin, az an pas jayat bar asmanast."

Diwan-]-Shams-1-Tabriz.

* i.e., the faqir's rag 
4 From the moment you came into the world of being A ladder was placed before you that you might escape, First you were mineral, later you turned to plant, Then you became aninial : how should this be a secret to you ? Afterwards you were made man, with knowledge, reason, faith, Behold the body which is a portion of the dust-pit, how perfect it has grown!

When you have travelled on from man, you will doubtless become an angel,

After that you are done with this earth; your station is in heaven."

(NICHOLSON).

“Zan-i-khub, farmanbar, parsa

Kunad mard-i-darwish ra badshah." BOSTAN of S'ADI, chap. 7.

"A good, order-bearing, chaste wife Makes a poor man a king."

(ClaARKe).

" Z'an pish ki az jam-i-ajal mast shawi

Zir-i-lakd-1-hadisha past shawi, Sarmaya ba dast ar inja k'anja Sudi nakuni agar tihi dast shawl."

Omar Khayyam.

" Bestir thee, ere death's cup for thee shall flow, And blows of rutbless furtune lay thee low; Acquire some substance here, for none is there, For those who empty-lianded thither go." (Whivfiet.D).

“ Za palidi wa za khubi tu kuni surat-i-shakhse

Ki gurizad ba do farsang way az bue palidi

Kuniash ta'mahe khaki ki shawad sabza'e paki, Birahad u za najasat chu dar u ruh damidi."

Diwan-[-Shams-].Tabriz.

"Thou mouldest of foul and fair the form of a man

That he nay flee two le.rgues from the odour of foutness;

Thou mak'st him a morsel of dust that he may becoine pure herbage, IIe is free from tilth when Thou hast breathed into him a soul."

"Zar andar kaf-i-mard dunya parast Hanuz ey biradar bisang andar ast."

(NICHOLSON).

Bostan of S'AD1, chap. 2.

"Gold in the palm of the man's hand world-worshipping,

Oh bruther! is yet within the stone."

(CIARKE).

"Za ranj wa rahat dauran ma ranjan wa ma shu khurram Kl amin jahan gahe chunan gahe chunin bashad."

ANWAR-T-SUHEILI.

"Gricve not nor let thy heart be glad at this world's joy or sorrow, For know the scene that now seems fixed aye changes on the morrow."

EE.STWICK. 
" Zar'a-ra chun rasid waqt-i-diruu Na khiramad chunanki sabza'e nau."

Gulistan, chap. 6 .

" Not so elastic bends the yellow corn, As the young blade before the breeze of morn."

(EASTWICK).

"Zar bidih mard-i-sipahira ta sar binihad

Wagarash zur na dihi sar binihad dar 'alam." Gulistan, chap. I.

"Give thy troops gold that for thee they may die, Else they'll go seek a better destiny." - (EASTivick).

“Zare ki pak buwad za imtihan chi gham darad."

ANwar-i-Suheili.

"Gold that is pure, why should it dread the test?"

Eastivick.

"Zarra zarra k'andarin arz wa samast

Jins-i-khudra hamchu kah wa kahrubast;

Narian mar narian ra jaziband

Nurian ham nurianra taliband ;

Safra ham saflan raghib and

Dardra ham tiragan jazib shawand;

Batilanra chi rabayad batile

Aqilanra chi khush ayad aqile;

Ahl-i-batil batilanra mikashand

Baqiyan az baqiyan ham sar khushand."

ANWAR-I-Suheili.

" Each atom in this earth and heaven, we find

Resembles straw and amber to its kind;

Things igneous with fiery essences unite

And bodies luminous seek things of light ;

Pure natures wishfully pursue things pure

And gloom attracts the sorrowful and dure.

How are the vain seized on by vanities

And to wise men how pleasing are the wise;

The foolish fools to follow them compel

And others like them please as well."

Eastwick.

"Za sad chuba ayad yake bar hadaf."

Bostan of S'ADI, chap. 2.

"Out of a hundred arrows one comes to the butt."

(CLARKE).

"Zat-i-tu qadir ast ba ijad har muhal

Illa b'afridan chun khud yagana."

URF1.

"Thy essence is able to call into being all that is impossible,

Except to create one like Thyself." 
" Za zakhm-i-tu na gurizam ki sakht kham buwad

Dile ki sukhta'e atish-i-bala'e tu nist,

Kirana nist sana wa sanagaran-j-tura

Kudam zarra ki sargashta'e sana'e tu nist?"

Diwan-1.Shams-1.Tabriz.

"I will not shun thy blow, for very crude

Is the heart that ne'er burned in the tire of thine affliction,

To thy praise and praisers there is no end,

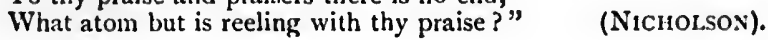

"Za zindan wa harif ahl ma gurez

Za bustan wa za na ahlan biparhez

Agar aqil buwad khasm-i-tu bihtar

Ki banadan shawi yar wa biradar."

ANWAR+I-SUHEILI.

" Flee not a prison with friends to thy mind,

But those unsuited e'en in gardens shun,

Thou wilt a prudent foeman better find

Than with a fatuous comrade to be one." EAsTwick.

“ Za z'uf-i-khud ma kun dar man nigah

Bar tu shab bar man haman shab chastgah,

Bar tu zindan bar man an zindan chu bagh

Ain mashghull mara gashta flragh

Pa'e tu dar gil, mara gil gashta gul

Mar tura matam, mara sur wa duhul."

JALALUdDin Rumi.

" I.et not a weakling like you censure me;

What seems night to you is lroad day to me,

What seems a prison to you is a garden to me,

Busiest occupation is rest to me,

Your feet are in the mire, to me mire is rose,

What to you is funeral wailing is marriage drum to me."

WHINFIELD.

"Za zulmat matars, oy pasandida dust,

Ki mumkin buwad k'ab-i-haiwan dar us't

Dil az bi-muradi ba fikrat ma suz

Shab abistan ast, ey biradar, baruz."

Bostan of S'ADI, chap. 6.

"O approved friend, fear not the darkness,

In which it is possible there is the water of life,

Consume not thy heart with failure of desire,

$\mathrm{O}$ brother, the night is pregnant with the day."

(ClaAke).

4' Z'ibtida daur-1-Adam ta ba ahd-i-padshah

Az buzurgan "afu bud ast, az faru-dastan gunah."

ANWAR-I-Stheth.I. 
"From Adam's time to thine, O king, 'tis still the same, The great extend forgiveness, and the lowly are to blame."

EASTWICK.

"Zidd ziddra mi-numayad chun Rum wa Zang." Jalal.uddin Rum.

"Opposite shows up opposite as a Frank a negro."

WHINFIELD.

"Zihi khurshaid-i-janafza, ki yak tabash chu shud paida, Hazaran jan-i-insani biruyad az gil-i-tira." Diwan-I-Shams-i-Tabriz.

"Welcome soul-producing sun! when a single ray of thine hath appeared, Thousands of human souls shoot forth from black (barren) clay."

(Nicholson).

" Z'ihtiyaj badtar dar jahau bala'e nist

Ba hich wajh tihidast ra nawa'e nist

Kase ki gasht dilash mubtila'e ranj tama “

Bigu bi-mir ki in dard ra dawa'e nist."

ANWAR·I-SUHEILI.

"The world no greater ill than want can show,

The needy wins no solace for his grief;

The victin of distressful want and woe

Must die ; for poverty finds no relief."

EASTIVICK.

"Z'in hamrahan-i-sust 'anasir dilam girift

Sher-i-khuda wa Rustam-i-dastanam arzu'st

Dar dast-i-har ki hast za khubi qurazhast

An m'adan-i-malahat wa an kanam arzu'st."

Diwan-I-Shams-I-TAbriz.

"My heart is weary of these weak-spirited companions, I desire the Lion of God (Ali) and Rustam son of Zal, Filings of beauty are in the possession of every one that exists, I desire that quarry and that mine of exquisite loveliness."

(Nicholson).

" $\mathrm{Zi}$ mulk ta malakutash hijab bar darand

Har an ki khidmat-i-jam-i-jahan-numa bi-kunad

Tabib-i-ishq Masiha dam-ast wa mushflq, lek

Chu dard dar tu na binad ki-ra dawa bikunad."

HAFIZ.

"They rend the veil between this world and the next for him who performs the service of the cup world-displaying.

"The physician of love has a life-giving breath like the Messiah and is merciful, but if he sees no pain in thee to whom is he to give his medicine?"

" Zi mushkilat-i-tariqat inan ma tab ey dil Ki mard-i-rah na yandishad az nashib wa flraz."

Hafiz.

"O heart from the difficulties of the path turn not the rein,

For the man of the path reflecteth not of ascent and descent."

Clarke. 
"Zinhar az qarin-1-bad, zinhar

Waqina rabbana "azaba 'nnar."

Gullstan, chap. 2.

"From a vixen wife protect us well,

Save us, O God! from the pains of hell." (EAstwick).

" Z'in past ashiyan ba faraz ashiyana shud

Azada bud wa zad juz azadagi na just

Tan ra ba tan guzasht rawanash rawana shud

Janash ba zat-j-Hazrat jan-afrin rasid

Birun za qaid-1-charkh wa zamin wa zamana shud."

The Dabistan.

"From this lowly nest he departed to the nest on high,

IIe was iruly free and sought no stores but those of holy freedom,

He abandoned his body to corporeal matter, and his spirit joined the spiritual region,

His soul was united to the Sulblime Being, the Creator of souls,

Soaring beyond the limits of heaven, earth and time."

(SHEA).

"Z'in pish birun za khwish pindashtamat

Dar gayat-1-sair-i-khud guman dashtamat,

Aknun ki tura yaftam ani danam

K'andar qadam nakhust bugzashtamat."

J.MI (BehaRIStaN).

"Formerly I thought Thou wast without me, and decmed that I should find Thee by long journeying,

Now that I have found Thee, I know this, that at the first.step I took, I left Thee bchind me."

(Aslatic JoukNaL).

"Z'in gambad-1-gardida bad af"all bin

Waz raftan-i-duistan jahan khall bin ;

Ta bitawani tu yak nafas khud-ra bash

Farda mangar, dar matlab hali bin."

Omar Khayyam.

"See what foul tricks this circling dome doth play,

See earth left empty of friends snatched away!

To live the onc breath you can call your own

Louk for no morrow, mourn no yesterday." (WHiNftelD).

“ Zun guna ki man kar-1-jahan mibinam

-Alam hama raegan baran mi-binam,

Subhan Allah bahr chi dar miyangaram

Nakami khwish andar an mi-binam."

Omar Khayyam.

"So far as this world's dealings I have traced,

I find its favours shamefully misplaced;

Allah be praised that I am one of those

Who're disappointed by it and disgraced!" WHINField.

“' Z'in sham 'aha'e sirnigun, z'in pardaha'e nilgun

Khalqe "ajab amad birun ta ghaibha gardad 'iyan." 
"From these stars like inverted candles, from these blue awnings of the sky,

There has come forth a wondrous people, that the mysteries may be revealed."

(NICHOLSON).

" Zi nur qina'at bar afruz jan

Ki rushan za khurshaid bashad jahan."

Pandnama of S'Adi.

"Illumine the soul by the light of contentment As the world is irradiated by the sun."

Gladwin.

"Zi panja diram, panj agar kam shawad

Dilat rish-i-sar-i-panja'e gham shawad

Chu panjah salat birun shud zi dast

Ghanimat shumar panj ruze ki hast."

Bostan of S'Adi.

"If out of fifty dirams five become wanting,

Thy heart with the grasp of grief becomes torn ;

When fifty years have gone forth from thy hand, Consider it gain that there is a space of five days."

(Clarke).

" Zirakan guyand k'andar marg nau'e rahatast

Wa za bayan in sukhan bar khalq minnat mi-nihand

Gufta and an kas ki mirad az du birun nist hal

Ya bade bashad ki khalq az jaur-i-u kamtar jahand

Ya kam azaru, neku khulqi ki ahl-i-ruzgar

Mihr-i-u warzand wa ura dar dil-i-khud ja dihand

Gar nekukar ast az in zindan-i-mihnat wa rihad

War bad andish ast khalq az mihnat-i-u wa rihand."

Anwar-I-StheiLl,

"The wise declare in death some pleasure lies

And kindly thus the explanation give :

One of two natures must be his who dies,

Or bad, whence others less agreeably live

Or inoffensive, of kind sympathies

So men him love and in their bosoms hive,

If good, he from this troublous world gets free,

If bad, men from his troubling freed will be."

"Ziraki za Iblis wa ishq az Adam ast,

EASTWICK.

Ziraki amad sabahat dar bahar;

'Ishq chun kishti buwad bahr khawas,

Gum bud afat, bud aghlab khalas."

JALALUdDIN RUMi.

"Cleverness comes from Iblis (Satan) but love from Adam, Cleverness is like Canaan (Ham)'s swimming in the ocean, Love is as the ark appointed for the righteous

Which annuls the danger and provicles a way of escape."

(WHINFIELD). 
“ Z'ishq-i-na-tamam-i-ma jamal-i-yar mustaghnist

B'ab wa rang wa khal wa khat chi hajat rue zeba ra." HAFiz.

"The beauty of the Beloved is in no need of our imperfect love, Of lustre and colour and mole and tricked line of eyebrow, What need hath the lovely face?"

(Clarke).

"Z'ittihad-i-hayula wa ikhtilaf-i-siwar

Khirad zi har gul-i-nau nagshi sad bayan girad

Man andar an kih? Dam kist in mubarak dam

Ki waqt-i-subh dar in tira khakdan girad?"

HAF 1Z.

"From unity of matter and contrariety of form,

From every new rose the picture of a hundred explanations wisdom taketh,

Whose auspicious breath is this that at morning time kindleth this dark dust-heap (the world)?"

Clarke.

" Ziyan mi-kunad mard tafsir dan

Ki ilm wa adab farushad ba nan.

Kuja aql wa shara fatwa dihad

Ki ahl-i-khirad din ba dunya dihad?"

(Bostan of S'AdI).

"The man Koran-knowing does injury

When he selis for bread the Koran and sound doctrine.

Where do wisdom and law give the decision

That one of wisdom should give religion for the world."

Clakke.

" $\mathrm{Zi} \mathrm{zanjir-i-na} \mathrm{parsayan} \mathrm{barast}$

Ki dar khalqa'e parsayan nishast

Agar hajate dari in khalqa gir

$\mathrm{Ki}$ sultan az in dar na darad guzir."

Bostan of S'Adi,

"He escaped from the chain of the impure Who sat in the circle of the devout, If thou hast any need, choose this society. For the Sultan even has no flight from this door." Clarke.

" Zi zuhd-1-khushk malulam biyar bada'e nab

Dame zi wiswasa'e aql bi khabar darad.

Dil-i-shikasta'e Haflz bakhak khwahad burd

Chu lala dagh-i-hawa'e kd bar jigar darad."

HaFIZ.

"I am vexed with dry austerity. Bring pure wine

For my brain ever fresh wine's perfume keepeth,

To the dust of the grave Hatiz's shattered heart will take with itself, The stain of desire that like the tulip it hath." 
" Zud ba saltanat rasad har ki buwad gada'e tu

Shah-i-nishin-i-chashm-i-man takiyagah'e khiyal-i-tust

Ja'e dua'st, shah-i-man bi tu mabad ja'e tu

Shur-i-sharab wa sirr-i-ishq an nafsam rawad zi sar

K'in sar-i-purhawas shawad khak-i-dar-i-sara'e tu."

HAFI

"To sovereignty quickly reacheth whoever was the beggar of Thine,

My eye's king-seat is the resting-place of Thy image;

A place of prayer it is. $O$ my sovereign, without Thee, be not the place of Thine!

Goeth from my head wine's clamouring and love's consuming at that moment,

When this head full of passion becometh the dust of the door of the abode of Thine."

(CLARKE).

"Zud bashad ki khira sar bini

Badu pae uftada andar band;

Dast bar dast mi-zanad ki darigh

Nashunidam hadis-i-danishmand."

GUlistan, chap. 7 .

"Soon shalt thou see the man of head-strong will

With his two legs by fetters pressed,

Smiting his hands, he cries in accents still

"To hearken to the sage is best."

(EASTWICK).

"Zud bini shikasta pishani

Tu ki bazi ba sar kunad ba ghuch."

Gulistan, chap. 8.

"Who play at butting with a ram

Will quick enough a broken forehead rue."

"Zud rawad, zud nashin shud ghubar

(EASTWICK).

Z'an ba yake jae na darad qarar

Kuh b'ahistagi amad ba jae

Az sar-i-an ast chunin dar pae."

Nizami.

"The dust goes quickly; it was quickly settled; thence it has no permanence in one place;

The mountain by gentle degrees attains its height; by reason of that it is so durable."

Asiatic Miscellany.

"Zulam-i-zulm chu zahir shawad, bar ayad pur

Jahan za tiragi wa talkh a shi wa tangi ;

$\mathrm{Ba}$ adl kush ki chun subh-i-an tul'u kunad

Farugh-i-an birawad ta hazar farsangi." Jam, Binaristan, chap. 2.

“When the darknesi of tyranny manifests itself

The world is filled with gloom, destitution and misery.

Cultivate justice; for when its morning dawns

The splendour thereol extends to a thousand parasangs."

(KEHATSRK). 
"Zulm shud im ruz tamasha'e man

W'ai ba ruswa'e farda'e man."

NizAMi.

"To-day oppression was my amusement, Alas I for my disgrace of to-morrow."

Asiatic Misceliany.

" Zulmate daram banisbat ba shamus

Nur daram bahri zuimat nafus

Z'an zaifam ta tu tabi awari

Ki na mard aftab anwari

Hamchu shahd wa sirka darham baftam

Ta sue ranj-i-jigar rah yaftam."

JaLALUdDIN RUMI.

"I still am dark compared to the sun

Though I am light compared to the dark souls of men,

Therefore is my light weak that you may hear it,

For you are not strong enough to bear the dazzling sun,

I have, as it were, mixed honey with vinegar,

To succour the sweetness of your hearts." WHINFIELD.

"Zumar bar khurad an kas ki dar jam"i sifat

Ba khwish bingarad, an gah tariq-i-an girad."

HAFIZ.

"Of life that one eateth the fruit who in all qualities

Looketh at himself, then the path taketh." (Cl.ARKE).

" z'Umar, ey pisar, chashm-i-ujrat madar

Chu dar khana'e Zaid bashi bakar."

BostAN OF S'ADI, chap. 5 .

“O son expect not reward from Umar,

When thou art at work in the house of Zaid." (ClarkE).

"Zummi 'llfadha in nadda, fa ma 'as'ada man zamma,

Wa rummi 'lamala 'rraththa, fagad 'aflaha man ramma

Warish man rishahu 'nhassa, bima 'amma wa ma khassa

Wa la tasa ala 'nnaqsi wa tahris ala 'liamma;

Wazawwid nafsaka 'lkhaira, wa d'a yu'kibu'dhdhaira,

Wa hayyia markaba 'ssairl wa khaf min Iajjati 'iyamma."

Maqamat of Hariri (zi).

"Bridle thy speech if it would run astray for how happy is he who bridleth it :

And mend thy ragged conduct, for he hath prospered who mendeth it,

And plume him whose plumage hath fallen in calamity great or small; and sorrow not at the loss and be not covetous in amassing,

And make provision of good for thy soul, and leave that which wil bring on ill, and prepare the ship for thy journey and dread the deep of the sea."

(Chenery). 
" Zurat az pish mi-rawad ba ma

Ba khudawand ghaib-dan na rawad."

Gulistan, chap. I.

" Thy power extends to us,

It does not extend to God the knower of Secrets."

“Zur-i-jan kuhkan shaqq-i-hajar

Zur-i-jan-i-jan dar an shaqqu 'lqamar."

Jalaluddin Ruml.

" The strength of strongest man can merely split a stone,

The power that informs man's soul can cleave the moon."

REDHOUSE.

“Zuyyina linnasi hubbu 'shshawati mina nnissa'i w'albanina w'alqanatiri 'lmuqantarati mina ldhdhahabi w'alfldhdhati wa'lkhaili 'Imusawwamati w'alan'aami w'alharthi." Koran, chap 3.

" The love and eager desire of wives and children and sums heaped up of gold and silver and excellent horses and cattle and land is prepared for men."

SALE. 


\section{INDEX OF AUTHORS}

Abdah ibn At.tabib, 86

Abdullah ibn Tha'labah, 173

Abd-ul-Malik, 14, 216, 299

Abu Duad, 8

Abu'l Ala, I4, 87, 13I, I33, I50, I 55, 172, 297, 304, 309

Abu'l Ghul, 297

Abu'l Qrsim Nasrabadi, 143

Abu Zubaid, I64

Akhlaq-i-Jalali, 62, 129, 229, 312

Akhlaq-i-Muhsini, 25, 172, 200, $204,268,280$

Al Buhturi, 168

Al Ibshaihi, 235

Al Ikd al Farid, 170

Al.Muthakkibu l'Abdi, 86

Al Tughrai, 13, 19, 85, 99, 123 , $126,188,199,244,255,292,316$

Ali al Murtaza, II

Ali Bin Muhammad at Tahamy, 198

Alif Laila wa Laila, 83, 89, 230, $237,238,286,289,315$

Amir Khusru, 24I

Amr ibn Kamiah, 3 II

Amr-ul-Kais, 234

Anon, 22, 77, 121, 160, 166, 299, 316

Anwar-i-Suheili, I, 5, 16, 20, 22, $26,27,31,35,36,37,38,40,42$, $43,47,48,52,54,56,57,59,60$, $61,62,65,66,67,69,70,72,73$, $74,76,77,80,81,85,87,90,91$, $92,94,95,98,100,102,103$, IIO, II I $115,116,118,119,120$, $121,122,123,124,125,128,130$, I $31,138,139,140,142,143,149$, $15 \mathrm{I}, 153,154,158,166,175,178$, $180,183,188,189,190,193,196$, 197, 198, 200, 205, 206, 211,212 , $213,215,216,217,218,222,224$, 226, 232, 235, 239, 241, 243, 244,
$245,246,247,249,250,251,253$, $254,255,258,260,26 \mathrm{I}, 262,263$, $264,265,266,268,269,271,272$, $274,275,277,280,281,282,288$, 289, 294, 302, 309, 3I3, 3I8, 32I, $322,323,324,326$

Anwari, 113,262

Arabic Proverbs, 10, 15, 16, 74, $127,142,145,160,165,171,172$, $184,188,230,238,261,277,305$ Ash Shanfara, 286

Attar, 63

Avicenna, 10, 110

Azizi, 244

Beha-Ullah, 90

Buzurgi, I4I

Dabistan, The, 46, 144, 232, 310, 325

Dhahir, 263

Diwan-i-Shams-i-Tabriz, I, 4, 6, 20, 31, 32, 35, 38, 39, 42, 43, 44, $46,47,48,49,50,53,59,60,6 \mathrm{I}$, $65,68,69,70,75,78,79,80,88$, 91, 93, 102, 105, 109, 114, I18, I 19, 135, 139, 141, 142, 143, 145, I $50,155,158,174,175,176,178$, $181,182,183,184,187,188$, I93, 200, $212,214,218,226,242,243$, $249,25 \mathrm{I}, 252,26 \mathrm{I}, 263,264,27 \mathrm{I}$, $274,280,281,282,284,288,294$, 301, 307, 310, 318, 319, 320, 321, 323,324

Duraid, 89

Farazdak, 207

Fariddudin Attar, 22, 147

Firdausi, 48, 90

Gulistan, The, $1,2,4,5,7,8, \mathrm{II}$, $12,13,16,17,20,21,22,25,26$, $27,28,29,30,31,32,33,34,35$, $38,40,42,43,44,45,46,47,48$, 
$49,5 \mathrm{I}, 5^{2}, 54,55,5^{6}, 5^{8}, 60,6 \mathrm{r}$, $62,63,64,65,66,67,69,70,71$, $72,73,75,78,79,80,81,83,87$, $88,90,91,93,94,95,96,97,98$, 100, 101, 102, 103, 105, 106, 108, I I $1,113,114,115,116,117,119$, $120,125,127,129,134,136,137$, I $38,140,142,143,149,15$ I, I 52 , I 53 , I 54 , I 55 , I 56 , I 57 , I 58 , I 59 . $161,162,172,173,174,176,181$, I $83,184,185,189$, I9I, 192, 194, 20I, 203, 204, 205, 206, 207, 208, 209, $210,211,212,213,215,216$, $217,218,219,220,223,224,229$, $231,233,239,242,243,246,250$, 251, 252, 255, 256, 257, 258, 259, $260,261,262,263,264,268,270$, $271,272,273,274,275,278,283$, $285,287,289,290,292,293,300$, $301,305,308,309,312,313,316$, $317,318,319,320,322,325,327$, 328

Gulshan-i-Raz, I38, I 39

Ghazzali, I8, 84

Hadis-i-Qudsi, 293

Hafiz, 6, 19, 26, 29, 32, 34, 39, 44, $59,61,65,67,70,74,75,77,78$, $84,88,92,93,98,99$, 100, J04, I10, I I 5, I18, I I $1222,123,125$, $127,137,140,152,159,160,174$, $185,193,194,195,198,200,201$, $202,203,207,208,213,215,224$, $225,227,230,235,236,240,242$, $246,247,248,249,251,252,256$, $257,258,264,266,272,275,282$, $283,285,287,288,290,291,305$, $310,318,324,326,327,328,329$ Hamasa, I 63

Hariri (Maqamat), 2, 3, 6, 7, 8, $12,15,16,17,21,22,23,82,83$, $84,85,86,87$, I 28, I 32, I 33 , I 34 , $144,145,159,162,163,164,166$, $168,169,170,178,182,231,234$, $238,245,252,256,258,26$ I, 270 , 279, 291 , 297, 298, 300, 301, 312, $316,317,329$

Hatim Tai, 190

Hittan, I 32

Husain ibn Mutair, 228

\section{Ibrahim ibn Kunaif, 160,270} Iyas ibn al Aratt, 217

Jafar ibn Ulbah, 85

Jalaluddin Rumi, $4,6,7$, 10, 14 , $16,20,21,29,30,31,32,33,37$, $39,42,50,5$ I $, 52,53,54,55,57$, $61,63,67,69,71,72,76,77,79$, 8o, 83, 91, 95, 96, 97, 99, 101, 103, 104, 106, 107, 108, 109, I 12, II4, II 5, II 7 II 1 , I20, I21, I22, 124, I 35, I 36, I37, I39, I 40, I43, I 44, I 45, I46, I 47,148, I 49 , I 50 , I 52, I $53,156,157,158$, I60, I62, $164,175,177,179,180,182,184$, 185, I9 I, 192, 194, 195, 196, 199, 201, 202, 203, 207, $210,213,214$, $216,217,219,220,221,222,223$, $225,226,227,228,229,230,23 \mathrm{I}$, $232,234,236,237,239,240,241$, 242, 244, 245, 248, 249, 250, 252, $253,254,255,256,257,258,260$, $263,266,267,269,272,273,276$, $277,278,279,280,284,285,286$, $287,289,292,293,304,306,308$, $311,319,320,323,324,326,328$, 329

Jam-i-Kai Khusro, 243

Jami, 2, 28, 36, 39, 4I, 58, 59, 65, $76,79,87,94,104,106,107$, 109, I I I, I 17, I 19, 121, I 24, 1 36, I 37, I 40, I 57, I89, I 90, 222, 228, $235,257,265,285,288,293,313$, 325,329

Junaid, 171

\section{Kasim al Anwar, 233, 259}

Katari, 84, 253

Kisa'i, 109

Koran, The, (2) 3, 4, 8, 9, 10, (12, (13) (14, (15, 16, 17, $18,19,22,23$, $24,25,66,67,82,84,85,(86,87$, 88, III, 126, 127, $128,129,130$, 131, 132, $133,134,135,136,138$; (149, I $51,152,155,156,157,159$, (160, $162,163,164,165,166,167$; $169,170,171,172,173,177,178$, $179,180,181 ; 183,184,185,186$, 187, $188,189,191,196,232,233$, $237,238,239,24 \mathrm{I}, 253,255,26 \mathrm{I}$, 
265, 266, 277, 294, 295, 296, 298, 299) $300,301,602,603,304,305$, 313. (314. 315, 316, 317, $33^{\circ}$

Kurrat al Ayn, 39, 143, 284

Labid, 4, 133, 296, 299

Lataif ul Muluk, 160

Majani ul Adab, 250, 29I

Mansur Hallaj, 209

Muhammad, Sayings of, $7,11,13$, $149,159,160,164,165,166,173$, $181,231,258,293,304$

Muwailik al Mazmum, 291

Nabil, 290

Nasir-i-Khusraw, 94, 102, 104, $211,28_{3}$

Nizami, 27, 88, 147, 243, 265, 288, 328,329

Omar Khayyam, 1, 2, 7, 21, 23, $25,26,27,31,32,34,36,41,42$, $43,53,54,55,57,58,63,64,68$, $71,74,77,81,82,88,94,96,98$, $112,114,115,119,123,129,130$, $134.136,1.37,139,140,149,154$, $163,174,177,180,185,190,192$, 205, 207, $210,218,221,224,227$, $23^{2}, 233,239,241,245,248,25^{8}$, $259,261,262,265,269,270,271$, $272,273,276,278,285,290,292$, $306,310,311,312,313,321,325$

Persian Proverbs, 114, 154
Rasikh, 126

Saadi, 142

S'adi, 44, 56, 94, 157

") (Bostan), 18, 26, 3.3, 34, 35, $37,38,39,40,41,44,45,47,48$, $49,50,51,58,59,62,68,69,90$, $9 \mathrm{I}, 92,93,95,96,98,100$, I 10, $125,138,142,151,152,161,163$, $176,180,185,193,195,196,197$, 198, 199, 201, 204, 205, 206, 208, 209, 210, $211,214,216,220,221$, $225,226,229,235,236,244,252$, $253,254,262,263,268,269,27 \mathrm{I}$, $273,276,278,279,281,282,284$, 294, 303, 307, 309, 31 5, 318, 321, $322,323,326,327,329$

S'adi (Pandnama), 46, 47, 59, 6I, $101,113,139,156,175,182,206$, $215,255,265,276,308,319,327$

S'aid, 32, 215

Sarabi, 25

Shabistari, 202

Shahi, 12, 254

Sherishi, 287

Subahani, i8

Sulmi ibn Rabiah, 298

Sultan Timoor, 264

Ta'abbata Sharran, 82, 131

Taubi ibn al Humaiyir, I70

Urfi, 24, 322

Zoheir, $8_{5}, 131,133,168,173,240$, 243 



\section{INDEX}

Abortive, every work not in God's name, 159

Absence, 76, 232

Absent, 62

Absolute, the, 60

Abstinence, 9 I

,, no concupiscence, no, 50

", when thou endurest not the pain of, 55

A bn Huraira, 304

Account, remember the day of final, 148

Act, when nne member of a tribe has done a foolish, $5 \mathrm{I}$

Action, breath without, 236

," necessary-is religion, 229

Actions, every man pledged to God for his, 159

, nothing remains but noble, 275

", slay the guilty their own bad, 197

," who sows ill, I13

Acts, God knows my secret, 134

Adam, 207

", children of, 165

", we are all members of, 177

Advantage, four things tend to, 43

Adversity, 27

Alvice, affects not those who can. not feel, 5

," is wind, 45

$\because$ my sire's, 223

Affection, hard to recall, 204

", hope not for, 168

". to gain thy friend's, 271

Afiliction, when bounty came, where lagged, 47

Age, and youth, 45, $3 \mathrm{II}$

", the changing watch of, 21 I

,, the people of this, 144
Aghush, 129

Airs, we put on-before strangers, 133

Al Kosai, 207

Al Wakaba, the guarded meadow of, 297

Ali, 109

All-informed, the, 169

Allah, 137, 298, 307

", knows the truth, sog

", seek with-refuge from Satan,

Alms, 169 2 I, 240

Aloes-tray, 2 I 2

$\Delta$ mbition, 280

Amir, be not vehement in addressing an, 59

Amity, show-to every friend, 19

Angel, 97

Angels come when fiendsfretire, 69 .

Anga, the, 36

Anger, 7, 49. 50, 83, 129

Annihilation, 67

Anv/ari, 114

Ant, 181, 194

", the-beneath thy tread, II 2

", the-of lust, 195

" the foe that was an-is now a serpent, 198

" would the-had not wings, 176

", wound not the, 44

Ants, when-assemble, 205

Appearances, 208

Arab, the sitting,by the.Tigris, 18

Araf, 80

Archers, 212

Archery, 285

Ark, 295

Armies, no need of-where no antagonist, 50 
Arrogance, 4I

Arrow, bucklers useless against death's, 278

, cast one-straight, 253

", fate's, 57

" cannot bring back - which has

Arslan, 129 left string, 16

Art, is long, 23r

Artisan, the heavenly, II4

Ascetic, the, 225

Ashes, I55

Ass, the-is dull, 192

, the wild-dressed whole, 4

Athirst, to those, 278

Atom, the motion of every, 146

Attainments, 89

Attraction, draw the soul without a ladder, I43

Avarice, 34, II 3

Babbler, 280

Babe, dependent on its father, 278

", love as a new born, 17

Back, hent, 225

Bank, safety is on the, I69

Barley, sow-you cannot reap wheat, 176,307

Base, the, 7 I

Bazar, when the wife takes the path to the, $5^{8}$

$\mathrm{Be}$, and it is, 133

Beasts, the vilest in God's sight, 26 I

Beauty, I74

", I weighed thy-against the morn, I 26

Bee, the, 108 II 5,294

Beginning, everything small at the, 160

" was-as clear as the ending, 170

Being, no crime worse than thy, 214

Believe, if ye-not, $8+$

,I signs to people who, to

Believer, the--not stung twice, I72

,, the heart of the, 23I

Believers, 304

,, true, 229
Believers, victory falls to the, 199

" wilt thou compel men to become, 3

Belly, 105, 262, 290

, the source of man's life, I 89

Beloved, presence of the, $3 \mathrm{I}$

", the remembrance of our, 234

, union with the, 120

Benefactor, 224

Bird, 200, $20 \mathrm{I}$

Birds, 72, 78

" to catch, 5

", will flock with birds of their own feather, I6

Birth, high, 99

Bitterness, 2 I I

Blanket, ten dervishes may sleep under one, 60

Blaze, what guide needed to the solar, 125

Blessings, blessing increases, 263

Blind, 3

, the, 4

,, wisdom learned from the, I74

Bliss, I78

Blood, whole earth not worth one drop of, 199

Blow, the, 15

Boaster, 80

Body, cherish not thy, 185

,, full of good and evil, 303

, not veiled from soul, 273

, the, I44, 177

,, two souls dwelling in one, 209

Bone, every-contains some marrow, 72

", you may devise to swallow the rough, 209

Book, this-a guide to God-fearing, 66

Borrowing, 74

Bough, the-full of fruit, 215

Rountiful, be, I 45

Bounty, let not-be followed by injury, 252

Bow, ere yet the-be strung, 176

Boy, the wise, $15^{8}$

Bramble, who sows the-will not pluck the rose, 260 
Branches, barren, 260

Bread, care for thy son's, 100

", no-till the corn be ground, 272

", the heggar's, 23

" the faithful pine for daily, 230

Breast, the door of whose-hath been opened, 177

Breath, life hangs on a single, 142 ,. whence came this, 78

Bride, a fair, 140

Brim, the wine of God's grace hath no, 26r

Broils, 174

Brother, ne'er grieve thy, 270

Bü, 262

$$
\text { pardon thy, } 256
$$

Building, founded on the fear of God, 3

Bnlbuls, 36, 205

Burden, endure the-of the feeble, 49

Butt, he who composes makes him. self a, I 84

", not every time does the archer hit the, 204

", of a hundred arrows, one comes to the, 322

Butter-milk, no one calls his own - sour, 154

Cage, the birdless-has no value, 101

Calamities, despair not in, 168

Calamity, I 44

, a person overtaken liy, 229

Calumny, avoid, 283

Camel, how can camel-driving be done without a, 150

"I ride not on a, 204

" passeth through the eye of a needle, 171,263

" the - goes day and night, 21

" thorn eating, 293

", when Bactria s-faints, 293

Cane-brake, when thou settest fire to the, 47

Caravan, life's, ' 34

Care goes with thy treasure, 42
Care, thou whose heart is full of, 304 ", who flies from home has no further, 55

Career, they who choose an unjust, 115

Carelessness, the ear of, 34

Carrion to the wolf, 259

Cat, the religious-can pray, 78

", the-may lacerate the leopard's eyes, 205

Celibate, pass not thy life a-288

Certainty, I8

Chain, the-is on the lion's neck, 262

Chalice, madc with art profound, 139

Champings, hot-of thy spirit, 102 Chance, 89

Character, hear thine own-from the enemy, 319

Chaste, when the wife is, $5^{\circ}$

Chastity, 123

", the house that hath not, 59

Chattels, when the-are thine, 197

Chessmen, we are but, I80

Child, new born, 248

Choice, leave a man to his, 155

Christians, 167, I8I

Clay, 68

", lureak the idnl of, 35

", devils are fashioned from, 104

, mankind moulded in, 177

,, perfumed, 103

Cleverness, 7, 326

Clod, 152

Clods, they who throw, 15 I

Clouds, 255

Coin, 72

,, the base, 231

Colocynth, the-brings not the date, 252

Communion, the house of, 148

Companionship, profit by, 93

Company, bad, 141

, fools', 267

," princes', 267

Comrade, a distasteful, 232

Conceit, 205

" cannot profit against truth, 132 
Concerts, God protect us from, 87

Condescension, 152,212

Conflict, danger in the, 231

Constancy, hope not from fortune a, 66

Contempt, from the dust of trial, $23 \mathrm{I}$

Contentment, 15, 51, 73, 199, 214, $235,263,310,327$

Contest between two persons, 193

Contrition, 79

Cord, the broken may be joined again, 56

Corn, the yellow, 322

", who eat their-while it is green, I 17

Corpse, rejoice not at the-of thine enemy, 77

," use wine to wash my, 78

Connsel, father's-to his son, 225

Counterfeit, 19;

Courser, in battle outvalue stall-fed ox, 21,79

Court, they who worship in God's, 70

Courtesy, show-to every foe, I9

Covetous, the desire of the, 162

Covetousness, 228, 262

Creator, no error in earth's, 100

Creature, to the-will belongs not, 96

Creeds, some lonk for truth in, 233

Crepuscule, horizon takes its bue from the, 287

Crime, one stained with, 60

Crow, 122

Cup, common stone may break a golden, 95 no solace left but the, 7

cü, when a ravenous-finds meat, 56

Curds, ror

Cure, think of the-before the thing occurs, 128

Curl, thy, 32

Cushion, on honours', 274

Darkness, sunlight succeeds, 76

Danghters, 295, 296

David, I07
Dawn, 123, 259

Day, Io, 138

, night pregnant with, 323

Dead, destroy not the good name of the, 129

" shame on the-whose task is unfinished, 135

we are the sons of the, 209 when I am, 53

Deaf, canst thou make the-to hear, 4

Death, 3,6 , II, 14, I 5, 23, 44, 57, $84,85,162,186,198,207$, 218, 241, 243, 249, 253 , $273,294,299,308,326$

", every soul shall taste of, I59

", in my foes - what joy, 186

" indulge not in joy at another's, I80

", is not-thy doom, 16

" of the poor, 188

Deceit, 282

Deed, a good, 214

" keep thyself free from evil, 60 . Deeds, evil, 232

" had my-deeds been like my words, 93

, rise by, 99

Deer, II 5

Defeats, 214

Deliberation, 35

Demons, many-with men's faces, $5^{2}$

Desert, in the, 33

", sweet is slumber in the, $15^{8}$

Desire, consume not thy heart with the failure of, 323

" of wives and children, 320

", sensual, II9

" the-in the desolate heart, 195

$"$ the seed of, 82

", what you have no hope for, $28 \mathrm{I}$

Desired, the-obtained 44

Desolate, king will not extract. tribute from, Ioo

Despair, 77, 172, 3or

Despoiler, 198

Destiny, 44, I5 $\mathrm{I}$ 
Devil, 84

Devils, 104

Devious, the, I 5 I

Devout, the circle of the, 327 the, 287

Difficulties, do not turn from, 324

Dirams, if live out of fifty-be wanting, 326

Director, having chosen thy, 53

Disciple, safer from the disbeliever than the, 33

Dissppointment, 29 I

Disciples, 201

Disgrace, 67

", no distress brings, 164

Distressed, go seek out the, 29

Dog, a-would defile a cistern of rose-water, 27

,, a wet, 255

iit the cave-sleepers, 255

Dolt, the, 2, 230

Dominion, 2

Doom, none outruns his, 160

Dooms, 240

Door, ill fated he who turns from the, 25

, who is at the, I05

Doors, enter houses by their, 286

Doubt, hand of truth rends the cloak of doubt, I 32

Dream, the world only a, $7 \mathbf{I}$

Drum, do not beat a-under a quilı, 70

,' oh noisy, 8I

Dullards, 206

Dust, I I 9, 328

," tread gently on this, 221

Dweller, dignity of dwelling in the, 261

Ear, 105

, lend not thc-to selfish men, 183

,, take cotton of evil from the minds', 227

,, the mind's, 22 I

, the thoroughfare for the Koran, IIO

Earnest, him who cometh to the, I Earth, 35, 39, 219
Earth, all-his who flies from home, 55

, so transient is this, 147

,, the-a murtar, 257

,, we come from the, 306

Ease, pompous, 13

Edifice, must have sure foundations, 35

Effects, trace causes to their, 286

Egress, try the-before you enter, 229

Egypt, 193

Elephants, gnats can overcome, 22 I

," they that make war with, 2 ro

Eloquence, 83

Embrace, open your arms if you clesire an, 35

Emprise, waste not the seed of thy, 320

Encouragement, who then to a base man givest, I 54

Endurance, 60, 271

Endured, they who have patiently, 178

Enemies, the most magnificent of thine, 2

Enemy, choose an-you can vanquish, 48

,, upon wliose favours conferred, I 3

Enfranchisement, die if thou would'st gain, 35

Enjoyment, 87, 297

Ennui, 175

Envy, 55, 275

Erring, to his own loss the-err, 183

Error, 182

Eternal, fix thy heart on the, 68

Eternity, how to attain, 4

Ethiopian grows not white with a

Evil, i 72 hot bath, 34

, learn-from thyself, 283

, turn away, 127

,, who does no, 12

Evolution, 53, 32 I

Exaction, king's, 5

Example, happy the man warned by, $\mathrm{S}_{4}$ 
Excellence, keep silent if you have not, 56

Exertion, man's-no use without God, 46

Existence, 205, 236, 279

Eye, I05

, the greedy, $25^{\circ}$

Eyes, king recognising, 67

Face, 67

Faith, 5, I17, I3I

" can move a mountain, 230

," men of God's true, 263

,, no value after death, 235

Faithful, the-are brethren, I33

Faithfulness, 175

Fall, 4r

Fallen, when one has, 27

,, who pities not the, 38

Falsehood, is fleeting, $\mathrm{I}_{3} 8$

Fame, 70

Fancy, no-without some truth, 97

," the bird of, 204

Faqir, the, I I

Fasting, I 3,59

Fate, 44, 54, 56, II I I I 3,233 , every man's, 159

Father, learn what thy-knew, I9I

Faults, II 5

"withhold thy-from sight, 78

Favours, 289

Feet, snares laid to catch our tripping, 30

Feridun, 9o

Fidelity, want of, 33

Firdausi, 36, 44

Fire, by wind, becomes more lofty, 45

Flame, the Guebre's, 5

Flatterer, heed not the, II

Flesh, the, 69

Flowers, Nirvan's, 98

Fly, 67

Foe, 72, 73

Foeman, prudent-better than factious comrarle, 323

Foes, 72

Folly, 130

" the five marks of, I24
Fool, 139

" a wise man understands the, 8

", heaven supplies wealth to the,

35

, old, I33

, silence, the answer to a, 142

Foolish, lie, 7

Fools, 16, 27, 322

," man may be too kind with, 12

Forelock, God holdeth every crea. ture by the, I $8 \mathrm{I}$

Forgiveness, 233

Form, 269

$"$ and reflection, $25 \mathrm{I}$

, each-has its archetype, II8

, the outward, I02

,, without life, I49

Formal, the prison of the, 285

Fortitude, I9

Fortune, 28, 94, 99, 121, 170, 238

" blame not unkind, I68

", rely not on, 82, 297

," trust not, 86

Founder, the great, 272

Fowler, who will not sparrows spar, 258

Fragments, one can light a fire with, 34

Frame, 28

Freeman, 98

Friend, a token of the, 282

, do not forego an old, 313

,, make not-of the world, $3{ }^{1} 3$

, news of a, I Io

,, united with ny, 239

, weep not for distant, I66

," who consorts with your enemies, 37

Friends, 72, 73, 74, 112, 267, 268, 289

, a breach among, 294

,, agreement amongst, 36

," he who would have, I 42

" he whose-are in a dungeon, 309

", spurn faithless, 32

, tak with, 64

Friendship, 56, 68, 73, I 10

, the day of-when we meet, 249 
Furniture, 160

Future, had I known the, 171

Futurity, he who giveth-to the wind, 175

, the prophets chose, I6

Grin, lust of, 40

Garden, the spiritual, 39

Garment, old, $15^{\circ}$

, the unclean - dashed by washerman against stone 283

Gear, worldly, 5

Generous, be, 142

, he who would call mankind, I 17

the, 13,196

Gentleness, pursue, 59

Ghaul, 4

Giaour, 96

Gift, the poor ant's, 4

Glory, 166

Goblet, broken, 262

God, 9, 13, 14, 32, 38, 46, 63, 66, 67, So, 81, 82, 86, 99, 107, 109, 126, 127, 129, 131, 132, 134, 146, 147, 155, $156,160,165,166,170$, $17 \mathrm{I}, 173,174,180,184$, 185, 186, 187, 189, 191, 195, 196, 206, 212, 223, 228, 232, 237, 238, 242, $243,253,264,267,269$, $276,281,284,285,286$, 292, 294, 295, 296, 298, $300,301,302,303,306$, $307,313,317,322,325$,

, connection with, 194

,, faith and piety prized of, $\mathbf{2 3 5}$

, , family of, 175

, favours the liberal, 189

, fearer of, 286

", friends and foes given by, 95

" grandeur belongs to, 157

," have mercy on the wicked, 64

", helps those who glorify hin, 283

keep to the fear of, I ro

", knows what is best, 255

, life misery without, 299
God, love of, 135

" one pull from, 143

" orders our lives, 98

", path of, 173

", praise of, 9

", prophet cares for naught but, 99

remember, 82

"round about the unbelievers,

23

„, seek-in broken hearts, 293

1, the best of providers, 296

", the essential attributes of, 178

", the light of, 188

" the lion of, 324

, the man of, 215

, the weaver, 47

", they who sowed no seed for, 310

, think on, 294

"who trusts in, 153

" who would not die for love of, 25

whom-shall guide, 87

", withholds grace from none, 61

", you can't have-and the world together, II 2

Gold, 47, 134, 321, 322

", ass's neck encircled with, 70 , 240

, give thy troops, $3^{22}$

", the copper of your existence changed to, 193

" the touchstone discovers the, 176

Good, 64, 172, 219

" and bad must die, 213

" be thou but, 212

, do-and speak not of it, 145

", if thou doest, 21 2

" man never weary of praying for, 172 seek to do, 21 3

", when thou reckonest thyself among the, 49

Goodness, I 16,164

Grace, heavenly, 94

," seek means of, 69

," the Holy Spirit's 84 
Grace, would'st thou God's obtain, 119

Grave, the, I33, I4 I, I 73

Great, now will he be called, 42 , the, 4 I, 243, 324

Greatness, I 84,191

Greed, I23, I90

, destroy, 22

, quit, 24

Grief, 183,238

" no longer hug your, 43

", no man comes to-who knows his place, I 65

" none honoured till they suffer, 271

, the heaviest wave in, 222

Guest, honour the, ?

Guile, 88

, avoid, I90

Hafiz, 93, I I0, I27

Hair, white-comes, 197

Hands, wash the dross of life from thy, 65

Happiness, I 86

Harlot, 262

Harvest, 68

Haste, 27

Hate, the seed of, I 66

Hatred, hell the root of, 20

,, uproot, 215

Hawk, be like the-not the raven, 48

,, white-not made from dingy

Head, 75

$$
\text { crow, } 116
$$

", when thou seest a severed, 48

"without reason, 257

Health, hope for good, 289

Healthy, the enjoyment of the, 199

Heart, beware the sigh of the wounded, 120

, contrite, 264

", do not pain a single, 274

," illumined with light of love, I 5

", shake off dust from mirror of the, $22 \mathrm{I}$

., the, $63,176,183,275$
Heart, the prison of the secret is the, 68

Hearts, God hath not given man two, 178

,, the abode of devils, 156

", who tear their-from worldly things, $13^{8}$

Heaven, 43

," messengers of, 97

Heedless, a thousand speeches profit not the, Io

Height, no test of value, 208

Hell, I 62

Helplessness, remember the day of, 92

Hemp, the shame of, 210

Heresies, 147

Hill, dig from a, 94

Hint, a-sufficient from the wise, IO

Hippocrates, 23I

Hog, slay the-or bind on the Zinar, 63

Home, he who abides far away from his, 37

, life's, I10

Honey, I 28, 223

Honour, the most worthy of-in God's sight, 132

Honours', life's 92

Hope, 39, I9I, 28I, 285

" be not without-in adversity, 27

, long delayed, 289

", succeeds hopelessness, 76

Hostility, no war without, 50

Houris, 233

Hours, youth's circling, 66

House, each comer greets a new, I1 6

How, reason at a loss to understand the, 6

Humility, 40, 4I I 140, 276, 279

Hunger, 286

Hurricane, a hundred jewels not worth one, 20

Hyacinth, 100

Hypocrisy, blue turbans a sign of, 84 
Ice, 93

Ideas, the mcadow of, 285

Idol, 4 I, 202

Idolatry, religion even in, 202

If, 54

Ignorance, the beast grew with, 91

Ignoble, why lament the, 220

Iil, the darts of coming, 153

IIl-doing, 168

Ilusion, life immersed in, I8 , the world an, 18

Imitator, the, 253

Impossibilities, 118

Impulse from God, 310

Incendiary, the lamp of an, 139

Indolence, 244

Iré, 211 bloated, 13

Infidel, 96

Infidelity, if a saint imbibe, II4

Infidels, 149, 150, 171,298

Injustice, 77,156

Intelligence, 257

Intoxication, where there is wine there is, 33

Irak, 274

Iron, nail of-cannot pierce a stone,

5

Israel, 305$$
5
$$

Islam, 15,181

, no monkery in, 165

Jackal, 262

Jacob, 308

Jam, cup-bearers of the banquet of, 290

Jami, 288

Jamsheds, 112

Jar, when ulcerated lips have pressed the, 65

Jehun, what do the people ofknow of water, 44

Jesus, 135, 181, 245, 30I

" a sufficient helper, 135

", buy not the ass with the gospel of, 34

Jew, when the-grows poor, 127

Jowel, every maxim is a, 119

Jews, 67
Joseph, 59, 308

Judgment, 167, 234

" day, 128, 165, 237, 248, 250, 299, 302, 303, 304, 305,

Just, be, 43

$$
314,315,316
$$

Justice, 2, I 38, 139, 329

Kaaba, 193

Kernels, nuts without, 149

" sound shells often cover foul, 226

Khosraus, 112

Kindness, break the colt with, 242 " misplaced, 257

King, 259

, the skilful exercises, 125

" difference of-and slave, 88

", the, 215

," word of a, 268

Kingcraft, 210

Kingdom, when thy real self is thy, 57

King8, 217

Kitchen, earth's, 310

Knot, from the skein of the uni. verse, $12 \mathrm{I}$

,, remains in the joined cord, 56

Knowledge, 125 ,

" follow not that of which thou hast no, 167

" the angel grew with, 91

, to gain, 59

, traditional, 57

Koran, 3, 19, I10, 130, 170, 171, $182,239,306$

Labour, 25

after, 220

Laila, 76, 108,170

Lamp, which God has lighted, 46

Land, choose a - which pleases thee, 287

not decked with plants, 291

Language, 81

Law, the burden of the, 187

Learning, a folly, 39, $j^{1} 2$

", seek, 293

,, without practice, 128

Leg, a locust's, 4 
Letters, hegging, 242

Letter-writer, only know the letter's purport

Liars, 158

Liberal, he, 197

Liberality, 255

Life, $23,46,91,142,157,198$, $24 \mathrm{I}, 250,278,287,290$, $292,308,312,317,329$ dross of, 65

fairy waters of, I

how to order thy, 248

if God has written thee long, $5 \mathrm{I}$

is short, $23 \mathrm{I}$

," let us cut short the ills of, 217

", look on-as occasion, 30

love the water of, 1

offers two things, 70

one breath of-flies each moment, II 4

pass-in pleasing others, 288 rely not upon perishable, 46

, the world's, I28

Light, lamp gives no-in the sun, 46

, , the dolt who sets up a camphor, 2

Loaf, a single-will supply the stomach, 250

Lord, a day with thy, 3I4

" call upon your-humbly, 23

" hearken unto your, 136

", heaven's sovereign, 264

," nothing escapeth the, Igo

", serve thy, 294

", the-caused our acts to be, 256

," those that fear the, 164

Lore, life's-wrought, 7

Love, $20,68,78,79,88$, 105, I35, I 36, I43, 144, 164, 225,

$227,228,242,256,273$,

$277,289,316$

", of two sorts, 14

", the alchemist, 264,

, the people of, 289

," the voice of, II 8

", the water of life, I, 289

, to win the Shepherd's, IIO
Love, when seeking, 64

Loved, do you see the-and hated together, 23

", he who has, 236

Lover, 194

", the-a monarch, 20

Lovers, 75, I9I advice to, 211

Lowly, the-are to blame, 324

Lust, 2, 50, 123, 124, 208

, battle against, 22

", carnal, 218

, of gain, 40

" the eye of, 67

Iute, I am thy, I82

Macrocosm, 220

Magic, the talisman of, I 60

Magnet, thy love is the, 226

Mahmnd, 36

Majnun, 76, 108

Malignant, give not opportunity to the, 176

Man, 2, 24, 74, 91, I32, I33, 156 ,

I $57,165,186,281,296$, 298, 303, 321

", a wise, $8,28,232$

, an envious, 11,137

," demand no tax from the poor, 153

" do not lavish learning on a wicked, 277

, every garment cloaks a, 72

" foolish old, 3 I 6

", furious, 219

", honourable, 17 .

,, honoured by trial, 234

", ignorant of the joys of life, 87

„, Koran-knowing, 327.

", many a righteous-turned to dust, 24

may he too kind with fools, I2

must drink the cup of misery, 286

merit of a, 204

of headstrong will, 328

that for which a-hath striven, 163

the dignity of a, 230

the virtuous, 213 
Man, the wings of a, 20I

" the worthless, 226

", thinkest thou cvery - a man, 8

", roid of understanding, 209

", when a-understands eating and sleeping, 48

" who is less than a woman, 51 who needlessly wounds, 134 who walks in God's own way, 251

Mankind, 156, 299

" the most foolish of, 8

Manly, be, 25I

Market-place, who goest empty handed to the, 142

Mate, a congenial, 186

Meddling, 64

Meekness, 25

Men, dissolute, 148

", old, 2 Io, 2 I 4

", the worst of, 26r

Merchant, 305, 317

Merciful, the, 152 ,

Mercies, many are the secret, 8

Mercy, !2

", show, 29

", use not-with ice water, 226

Merits, display thy, 78

"1 refuse to purchase, 125

Mickle, every-becomes a mite, I 59

Microcosm, 220

Mild, be, 272

Mildness, 277

Mina, 4

Mine, the-within the mountain, 158

Minstrel, 203

Mirage, let not the-beguile you, 86

Mire, if a jewel fall in the, 142

Miser, the, 264

Mite, cvery mickle becomes a, 159

Mole, the, 2 I 6

Monarclis, commands of, I 24

Money, abides not with the careless, 232

Moon, 23I

," slines only in the night, 148

Moral ${ }_{B}$, he whose-are corrupt, 162

Moral worth, 125
Morn, all peace till the breaking of, 13 I

Morrow, look for no, 325

" what is now, changes on the, 321

Moses, 14I, 193, 202, 254

Mosques, to fail to see thy face in, Moth, 260

Mountain, the, $\mathbf{3 2 8}$

Mourner, 260

Mouth, from beauty's, 40

Muhammad, 196, 254, 314

Musk, 20I

Name, good, 98, 100

Nasir-i-Khusrau, 21 I

Nasrin, 100

Nation, governed by a woman, 164 Nature, 296, 318

" everyone acts according to his, 177

" evil-cannot show good, 318

"when the-is evil, 102

", your first, 52 .

Neck, beware thy tongue does not cut thy, $8 \mathrm{I}$

" let not thy hand be ticd to thy, 166

Night, 10, 138

" the dark-of the friends of heaven, 259

" when the sun goeth up, where stayeth, 47

Nightingale, $40,28 \mathrm{r}$

", among owls, 39

" cooped with crows, 43

", imprisoned for her voice, 279

Noah, 43, 295

Noble, the hearts of the, 238

Nothing, 266

Obedience, 142

Object, prize high a wished for, 188

0hs, 164

Oil, midnight, 206

Old, when thou art, 56

Omen, the happy, 252

Omnipotent, reliance on the, 284 
Opinions, differing from the king's, 157

Opportunity, 34, 92

, take care of, 2 I4

Opposites, I48, 324

Oppression, disgrace follows, 329

Oppressor, 82

Orange, none will eat the-from the dunghill, 65

Orator shall have his defects pointed out, 203

Others, to mount by, 242

Outlaw, 245

Oyster, not every-pregnant with a pearl, 204

Pagodas, 4I

Pain, we cannot rise without enduring, 299

Painter, 270

Paradise, I cannot be content with, I4 I

") the majority of those in, 32

Pardon, 283

Parents, be grateful unto thy, $3^{02}$

") the soul of our first, I40

Parrot, 279

Partridge, 78

Parsimonious, II

Parting, with loved ones, 158

Passion, I 24

Passions, our earthly, I49

Past, grieve not for the, 243

Pasture, better than the battle plain, I20

Path, oppose no barrier to a good man's, 24I

the slain on God's, I67

Pätience, I $51,172,183,211,270$

" reason's proof, 265

", reason's treasury, 40

" supplies to every word its key, 27

Peace, 142

Peacock, discomforted by his ugly feet, 260

Pearl, not always in the shell, Ioo

" should the diver pause, he'll never win the, 102

" the precious, 235
Pearls, when I dived without finding, 48

Pen, 231

Penitence, 3I

People, speak to-according to their understandings, 149

Perchance, 54

Perdition, throw not yourself into, 169

Pharaoh, I4I

Philosopher, my critics call me a, $7 \mathrm{I}$

Phoonix, I25, I 54

Pictures, fancy's, 214

Pigeon, I49

Pilgrim, the Hijaz, I 54

", what do the comfortable care for the tired, $30 \mathrm{I}$

Pilot, where Noah is the, 43

Pious, the vision of the, 201

Pity, 220

Place, cling not to a native, I68

, earth's labouring, I 19

Plän, no unmatured-can succeed, 35

Pleasure, of the flesh, I44

," pass from the-of animals, 25

" take your-while you may, 64

,, the value of a day of, 206

Poetry, 262

Pomps, earth's hollow, 88

Poor, heaven does not strike the, 43 Potter, 68

Poverty, II , 88, I49, 206

, God defend me from, 23

"I in -there is rest, IOI

Power, 2

Praise the Lord, 89

Prayer, 8, 9, 4I, 15I, I66, I74, 24I, 305

, lend not to him who neglects, 300

," poor man's, 29

Preacher, 55

Pride, 220, 282

," boast not of liaving no, 190

Prison, why fall asleep in a, 32

Professions, the best of, 213

ProfligacJ, 93

Profligate, I I9 
Promise, to whom a good-is promised, 3

Prophet, nieek man all but a, 149

," the, 215

Prophets, before the-came, 223

", purposes of the, II 2

Prosperity, 83

Proudly, walk not, 167

Purchaser, who will pay gold, 202

Pure, earth is the footsteps of the, 140

," of heart, 60

Qais, 86

Qazi, the, 234

Qualities, a man's, 275

, look to, 63

Quality, extremes of, 193

Quilt, do not beat a drum under a, 70

Race, Adam's, 28

Rags, 320

Rain, I, 4

" crystal - falls from black clouds, 27

Raindrops, the-and the ccean, 309

Raiyyan, 4

Ram, who play at butting with a, $32 \mathrm{~S}$

Rank, seck, I 2 I

," to whom-is given, 118

Rashness, springs from the devil, 179

Rational, be that is, $27 \mathrm{I}$

Reap, only - where you have sown, 67

Reason, 39, 124

, human, 102

Reckoning, the people's, 135

Reflection, form and, $25 \mathrm{I}$

Regret, 38,283

Religion, 54, 163, 164, 273, 304

", buy not the world in exchange for, 34

Islam your, 15

", people follow the-of their kings, 16

" the best, 299
Religion, they that barter-for the world, 69

Renewing, 146

Repeat but half of what you hear, 104

Repentance, 90, 172, 183, 238, 298 ," no use when life squandered, 45

Repose, he who was nursed in soft, 258

Resurrection, IO, 171, 207, 236

Rhymes, 23o

Riches, 5, 12

" who would wish for the

Right, I2 world's, 65

", will cnjoy-on others, forgetting your own souls, 22

Righteous, the, I33, 145, I65

Rizvan, 122

Robber, when the-finds success, $5^{8}$

Rose, garden, 39

," no-without a thorn, 29, 33, $4 \mathrm{I}, 48$

" none but the bird interprets the, 230

Roses, 306

, from the hand of ugliness, 40 Ruby, 98, 164, 257, 291

$"$ a stone which is changed into a, I I 2

Rust, 5

Saba, 203

Sa'di, 208, 253

Sage, the - who does but preach, 12

Saint, he is no, 204

Saints, I 53, 3 I I

" love the, I9I

"vexed, show their shallow. ness, 64

Saki, 207

Sanctuary, the-liefore thee, II 3

Satan, the deceits of, $\mathrm{IO}_{4}$

Satiety, eat not to cause, 206

Satisfied, be, 309

Schemes, why to another's care consign thy, 9 I 
Schoolmaster, when the-is gentle, 293

Scorpion, I 54

", place not thy finger on the, 207

Sea, the, 255,301

Seas, two-not alike, I89

Secret, communicate not thy, 244

", none can keep a, 244

", the-of God, 284

Secrets, 244, 265

Sect, only one-saved, $25^{8}$

Sedate, be, 27

Seed, 35, 158, 309

," sowing, 35

,, time, I6I, 2I 2

Seeds, who-finds, 184

Self, 6

,, journey out of, 295

Self-praise, 235

Self-reliance, 3 I 3

Selim, 123

Sense, the inward, 102

Separation, 91, 175, 302

Serpents, 320

Servant, arranges but God settles, 74

", God's, 52

Service, faulty, 293

of kings, 16

Setting, but a rising, IO3

Shafts, shot, return not, 213

Shah, 122, 259

Shame, 26I

", bewail the work of, $30 \mathrm{I}$

,' wretch devoid of, 33

Sheiks, 20I

Shiraz, I 57

Shirin, 76

Shoe, barefoot, better than a tight, 278

Sickness, what sick nian eats, source of, II 4

Sigh, slight not the-of God's creatures, 319

Signet. your heart as Solomon's, 156

Sikander, 284

Silver, 263,264

Silence, 268
Silence, through maintaining, 60

Simpleton, 270

Sin, bliss from the pardon of a, 197

," the leaven of, 189

Sinai, I7

Sinners, God fearing, 209

,, repent, 20

," when God desires to humble, 54

Sins, be afraid of thy-this moment, 37

Sirat, 300

Skill, 90

Skirt, from the-of one so fair, 61

", grasp his, 6I

Skull, fill ny-with wine, 248, 266 , what stream could fill the, 227

Slander, 45

Slanderers, you cannot esçape, 185 Slave, I 6

,, who taught me, made me his, I 8 I

Sleep, 243

Sleepers, ope not slumber's eye, 7I, 108

Slight, naught -- that God has framed, 36

Slinger, keep beyond range of a practised, 48

Small, if thou art, 96

Snake, he who is hitten by the, 274

Snares, life full of, 254

Sneezing, 22

So-and-so, preferred to God, 280

Sobriety, 272

Son, 121

", if the God of mercy had a, 130

, the degenerate, 225

Sorrow, 100, 313

", diet of, 26

", who for thy pleasure giveth, 98

," would'st thou keep thyself from, 37

Sorrowful, the, 39

Soul, $6,7,46,50$, I10, 127, I4I, $142,177,218,221,235$, $266,273,274,298$. 
Soul, better to make one's-rejoicc, 98

" he whose-is quickened with love, 115

" make provision for good of thy, 130

my-from every tarnish free, 99

the burdened, 169

the Primal, 146

the vision of the, 294

which art at rest, 24

Souls, who venture naught, 116

Source, everything returns to its, 160

Spark, perishes in the water, 41

,, quench the-to end the flame,

Speech, 268, 269

", bridle thy, 320

Spirit, 313

the just time for, 113

", is very subtle, 252

", our celestial-free, 3 I

", the, 69

" the seed of the, 61

" turn the mirror of soul to, 65

", which wears not love, 257

Spoken, you must prove what you have, 208

Spring, 203, 287

" whoever delays sowing in, 287

Star, fortune's, 154

Station, proud his - who for nothing hopes, 24

Stecp, the, 85

Stone, 263

" a common-may break a golden cup, 95

a rolling, 209

", fruit on him who flings abestow, 152

Stranger, for one friendly, 120

" remembers home in sickness, $18 \mathrm{I}$

", secure the-as thy slave, 116 Strength, 328

Strife, he only fitted for the, 83

Substance, labour for, 70
Suf, the, 267

Sugar, not taste-from the reerl, I , throw-to the parrot, 259

Sugar-cane, 115

Sultan, seal of proximity to the, 4 I " the praise of the, 119

Summary, man creation's, 74

Sun, 94, 157, 260, 301, 324

" lamp gives no light in the, 46

" no need of stars with a, 151

", none but the-can display the, 4,57

Sunlight, 217

Sunrise, 93

Surfeiting, 91

Swine, in the heart of each are found a hundred, 63

Sword, good-not made from faulty iron, 261

," no worse for worn sheath, 178

", suspended by single hair, 9o

", time a, IOI

", who dares unsheath the tyrant's, I 8

" who draws the unrighteous, 105

Swords, 277

Swordsman, 198

Taper, what cares morning tho' the - die, 85

Tartary, 273

Task, fate's, 85

Taverns, better to commune with thee in, 31

Teacher, esteemed higher than the father, 292

Temper, 205

Temperament, the human, 214

Thorn and the rose together, $4^{1}$ ", pluck not the, 238

,, upon the rose is found, 266

Thought, 76, 91

" all creatures enslaved to, 147

", good and evil, 319

", the glass of, 120

Thread, who unravelleth the, 167

Throat, place a padlock on your, 237

Time, change of, I 49 
Time, nar what-has done, 257

", spend well thy, Ioo

", the-that passeth away, 29I

Timidity, 272, 277

To-day, rejoice, $5^{8}$

Toils, worldly, 3I I

Tongue, 173,3 I8

, every thorn a, 205

", man hiclden under his own, 226

,, of pocts, 173

", one cannot bind the enemy's, 34 wounds of the, $17 \mathrm{I}$

Tooth, time's-bitter, 217

Torrent, you cannot bind the, 279

Tradition, heed not, 269

Tranquillity, 232

Transient things die, 237

Travel, 74, 254

Traveller, before the-reach his home, 182

Treasure, as grows thy, 42

", hide not the hidden, I6I

", no-without a serpent, 33

,, of luving kindness, 65

", who toils not, will not gain,

Tree, 62 206

" derives strength from root, Trees, had-the power to move, 62

" none cast stones at-unless fruit is there, 120

Trouble, be not discomfited by, 320

,, the-of man, 82

", whoever says I falls into, 184

Truth, 8, I2, 6I, I49, I7 I, 282

" conceited will not listen to, 309

", intellectual, 65

", is from the Lord, I3

," not from worldly men, 5

Turbans, blue, 84

Tyranny, 104, 257, 329

", eschew, 74

", help one oppressed by, 245

Tyrants, 22, 320
Tyrants, never live long, 245

," will not always live, 2 Io

Ugliness, roses from the hand of, 40

Umm-al-Ala, 29I

Umar, 329

Unbelief, 18

Unbelievers, 24, I79, I83

, good things bestowed on, 167

Uncongenial, society of thc, $25 \mathrm{I}$, 284

Universe, a knot from the skein of the, I 2 I

, this circle of the, $x 29$

, we reflect the -123

Unjust, the, 196

Unseen, the, I I 4

Unwolthy, fortune crowns the, 210

Upright, be, 22

Vain, the, 322

Valuable, only the - should be prized, 3I7

Vazirship, 252

Veil, of the-is lifted, 2I

", mortal ken lounded by the, 64

,, the-of God's decrees, 154

Vestments, one in saintly, II 7

Vigorous, oft laid beneath the clay, 29

Virtue, 95, 319

,, keep time to, 69

,, strive to gct, 244

Voice, 295

,, of a friend, 239

Voices, no-from the slain return, 96

Wailings, give not vent to angry, I 80

Waist, strive when the water possesses only thy, I6I

Wakefulness, 282

Want, 324

Wants, relieve the people's, 3 I9

War, 142

", he must risk his blood who joins, 17

"who flies in, I7 
Warning, heel the wise man's, 108 Warrior, the well-fed, 127

Waste, each-not untenanterl, 272

Watchman, must not sleep, 88

Water, 266, 27 I

" heart thirst not slackened with, 66

" whole world spring of - to the thirsty, 278

Water-wheel, imitate the, 29

Ways and Means, 269

Wealtb, $28,87,275,292$

" cannot deliver when deeds destroy, 22

", from hand to hand must go, 65

" if for the Faith thou bearest thy, 180

" little use to the dying, 190

" the misers', i 80

Wealth-dispensing, be, 197

Wealthy, him who has become, 2

Wedding dress, much trouble behind $a, 305$

Weeping, 103

Whelp, a wolf's, 307

Wicked, God guideth not the, 18I

,. the end of the, 265

Wife, 319, 32I

" a virtuous, 256

," a vixen, 325

"I of bad disposition, 254

Wight, a starving, 29

Will, God's, 226

Winds, to the - we go, 306

"when the-blow o'er the meadows, 305

Wine, 42, 78, 266, 269, 290, 310

" give me a skin of, 273

,, no solace but, 7

Wine.bibber, 96

Wisdom, 65, 185, 257, 271

" become partner with-now, 161

scek, 122

" strange to see-ask alms, 89
Wise, opinion of - not approved, 214

the, $27,31,218,240$

Wit-sharpening, 83

Wives, 296

Wolf, 97,280

" when the-howls, 23

, wolf-cub will becomc a, 7

Woman, 219

Women, men superior to, 19

Wood, II, 47

Words, deceitful, 226

," to the wise, 208

Work, a good, $15 \mathrm{I}$

Works, 165

", good, 188

," rich men's, 275

Workshop, the worker hidden in the, 153

World, 71, 95, 114, 130, 138, 139, 208, 261, 297, 308, 325

„, strive for joy in your own, 199

", the life of this, 269

", woe to him who seeks the, 271

World-creator, the 138

Woulds, 164

Wound, 218

", the hornet's, 106

Wrath, IO2

he tongue inflicts, 193

", doth grief contain, 103

Wretched, the, 262

Year, forty the-of perfection, 290

" lay not on the day the burden of the, 166

Years, when fifty-have gone, 58

Yesterday, mourn no, 325

Youth, 3I I

Zaid, 329

Zangbar, 93

Zeal, they who excel in, 143

Zinar, 63 



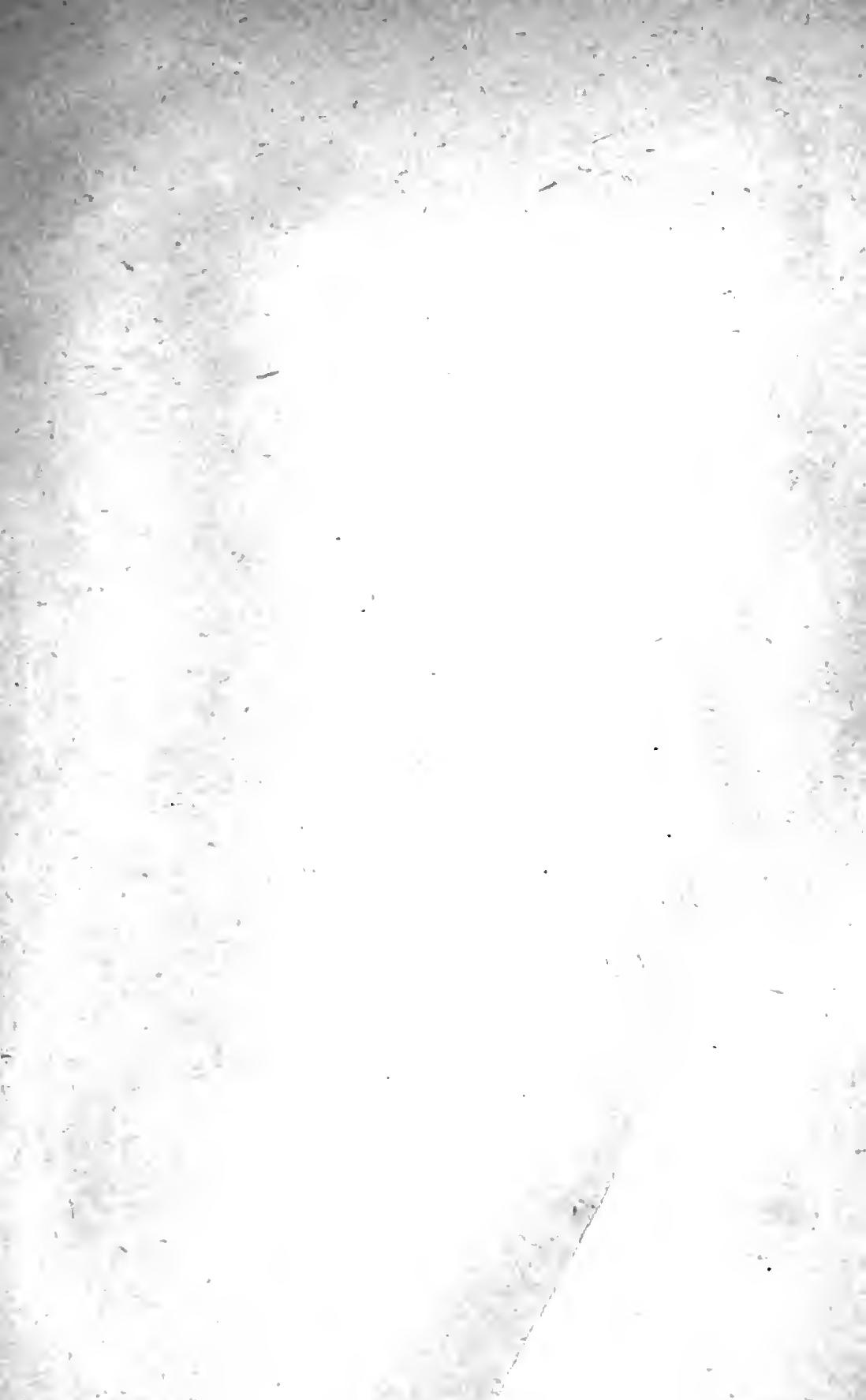




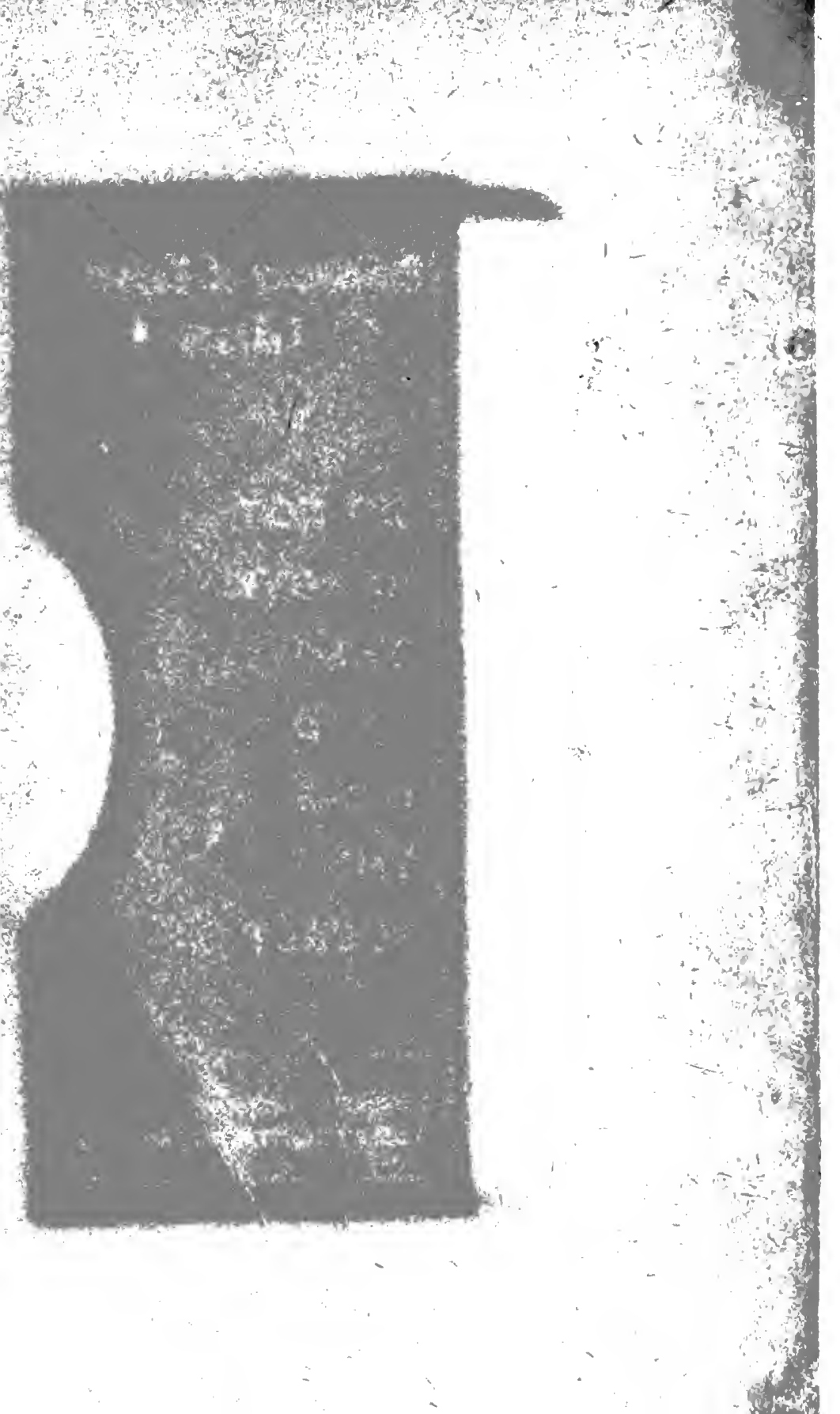




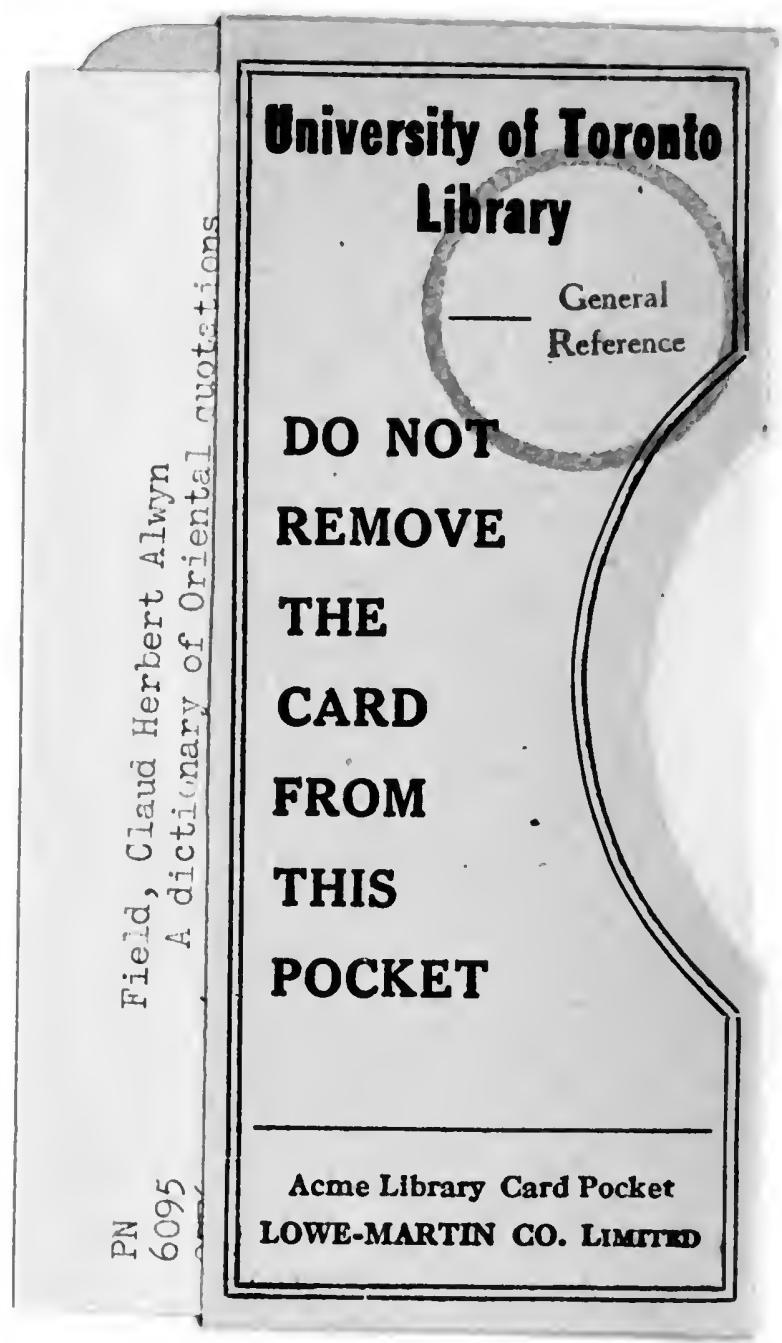


